\title{
Militaire dienstplicht : een economische analyse van de personeelscomponent in de krijgsmacht
}

Citation for published version (APA):

Duindam, S. (1995). Militaire dienstplicht : een economische analyse van de personeelscomponent in de krijgsmacht. [Doctoral Thesis, Maastricht University]. Datawyse / Universitaire Pers Maastricht. https://doi.org/10.26481/dis.19950421sd

Document status and date:

Published: 01/01/1995

DOI:

10.26481/dis.19950421sd

Document Version:

Publisher's PDF, also known as Version of record

\section{Please check the document version of this publication:}

- A submitted manuscript is the version of the article upon submission and before peer-review. There can be important differences between the submitted version and the official published version of record.

People interested in the research are advised to contact the author for the final version of the publication, or visit the DOI to the publisher's website.

- The final author version and the galley proof are versions of the publication after peer review.

- The final published version features the final layout of the paper including the volume, issue and page numbers.

Link to publication

\footnotetext{
General rights rights.

- You may freely distribute the URL identifying the publication in the public portal. please follow below link for the End User Agreement:

www.umlib.nl/taverne-license

Take down policy

If you believe that this document breaches copyright please contact us at:

repository@maastrichtuniversity.nl

providing details and we will investigate your claim.
}

Copyright and moral rights for the publications made accessible in the public portal are retained by the authors and/or other copyright owners and it is a condition of accessing publications that users recognise and abide by the legal requirements associated with these

- Users may download and print one copy of any publication from the public portal for the purpose of private study or research.

- You may not further distribute the material or use it for any profit-making activity or commercial gain

If the publication is distributed under the terms of Article $25 \mathrm{fa}$ of the Dutch Copyright Act, indicated by the "Taverne" license above, 
Militaire dienstplicht 


\section{CIP-GEGEVENS KONINKLIJKE BIBLIOTHEEK, DEN HAAG}

\section{Duindam, Simon}

Militaire dienstplicht : een economische analyse van de personeelscomponent in de krijgsmacht / Simon Duindam. Maastricht : Universitaire Pers Maastricht

Proelschrift Maastricht. - Met lit opg, reg. - Met samenvatting in thet Engels.

ISBN 90-5278-157-5

Tref.: dienstplicht; economische aspecten / openbare financièn. 


\title{
MILITAIRE DIENSTPLICHT
}

\author{
een economische analyse van de \\ personeelscomponent in de \\ krijgsmacht
}

\section{PROEFSCHRIFT}

ter verkrijging van de graad van doctor aan de Rijksuniversiteit Limburg te Maastricht, op gezag van de Rector Magnificus, Prof.mr. M.J. Cohen, volgens het besluit van het College van Dekanen, in het openbaar te verdedigen op vrijdag 21 april 1995 om 16.00 uur

door

SIMON DUINDAM

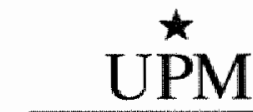

UNIVERS ITAIRE PERS MAASTRRCHT 


\section{Promator}

Prof.dr. J.G. Backhaus

\section{Co-promotor}

Dr. G. Meijer

\section{Beoordelingscommíssie}

Prof.dr. C.C.P. Wolff

(voorzitter)

Prof.dr. G. Knieps

(Albert-Ludwigs-Universität Freiburg, Bondsrepubliek Duitsland)

Prof.dr. J.A.H. Maks

Prof.dr. H.W.G.M. Peer

(Open universiteit) 


\section{Voorwoord}

Toen ik in mei 1990 in militaire dienst ging wist ik niet dat ik er pas vijf jaar later uit zo komen. Hoewel ik formeel na eén jaar weer buiten de kazernemuren stond, was ik nog niet klaar met mijn dienstopdracht en heb ik mij de resterende jaren met de dienstplicht als onderzoeksonderwerp beziggehouden. Het was voor de dienstplicht een hectische tijd. Discussies kwamen, commissies gingen en met hun ook de militaire dienstplicht, terwijl de sociale dienstplicht voorgoed aan de wilgen werd gehangen.

Voor u ligt dan ook het resultaat van het onderzoek dat ik in die tijd als econoom verbonden aan de Open universiteit heb verricht.

Militaire dienstplicht: een economische analyse van de personeels-component in de krijgmacht is niet zomaar tot stand gekomen. Vele ogen hebben het werk gelezen, vele monden hebben mij van advies gediend en gestimuleerd. Een voorwoord is dan ook niet afgesloten zonder al die mensen te bedanken, met in het bijzonder mijn promotor Prof. dr. J.G. Backhaus, mijn co-promotor dr. G. Meijer, de leden van de beoordelingscommissie, de leden van de Brown-BagGroep van de vakgroep Economie van de Publieke Sector aan de Rijksuniversiteit Limburg, de collega's aan de Open universiteit, de leden en bestuursleden van de Vereniging Van Dienstplichtige Militairen, de meelezers Prof. dr. J.G. Siccama en Brigade-generaal b.d. A.W. Schulte, mijn ouders en zus en last but not least mijn vriendin Lisa.

Ik ben nu eindelijk met groot verlof en wacht op de herhalingsoefening. 
औ 


\section{Inhoudsopgave}

1. ECONOMIE EN DIENSTPLICHT 5

1.1. Dienstplicht en belastingheffing 7

1.2. De visie op de samenleving 8

1.3. De welvaartseconomie en het welzijn van dienstplichtigen 9

1.4. Dienstplicht en schaarste. 14

1.5. De structuur van het proefschrift en de onderzoeksvragen 17

2. HET COLLECTIEVE GOED DEFENSIE 21

2.1. Defensie en economische theorie 21

2.2. Het geweldsmonopolie van de overheid 23

2.3. De organisatie van de krijgsmacht 26

2.4. Defensie, dienstplicht en het gedrag van ambtenaren 28

2.5. Dienstplicht, vrijwillige dienst en de rol van het 33

2.5.1. Het model 33

2.5.2. De invoering van de dienstplicht 35

2.6. Samenvatting 37

3. DE GESCHIEDENIS EN HET VOORTBESTAAN VAN DE DIENSTPLICHT IN NEDERLAND 39

3.1. Het ontstaan van de militaire dienstplicht 39

3.2. Plaatsvervanging 40

3.3. De periode na $1870 \quad 45$

3.4. Het voortbestaan van de dienstplicht in een 46

3.4.1. Het model $4 \mathbf{4 6}$

3.4.2. Aanpassingen van het model 48

3.5. Samenvatting 49

4. DE DIENSTPLICHTBELASTING 51

4.1. De omvang van de dienstplichtbelasting 51

4.2. De onderbroken loopbaan 56

4.3. De verdeling van de dienstplichtbelasting 58 
4.4. De inningskosten van de dienstplichtbelasting 61

4.5. Slotopmerkingen $\quad 62$

Appendix 4.1.

5. DIENSTPLICHT EN DE ALLOCATIE VAN PRODUKTIEFACTOREN

5.1. De theorie $\quad 65$

$\begin{array}{ll}\text { 5.2. Vervelling } & 67\end{array}$

5.3. Kapital-arbeid substitutie $\quad 69$

$\begin{array}{ll}\text { 5.4. Militairen en burgers } & \mathbf{7 1}\end{array}$

5.5. De substitutie tussen onervaren en ervaren militairen $\quad \mathbf{7 4}$

5.6. De personeelsbehoefte van de krijgsmacht in een $\quad 75$

5.7. De budgettaire consequenties van de overgang $\quad 78$ van een dienstplichtigenleger naar een

vrijwilligersleger en de "excess-burden" van een

dienstplichtigenleger

5.8. Conclusies

79

$\begin{array}{ll}\text { Appendix 5.1. } & \mathbf{8 0}\end{array}$

6. DE VRAAG NAAR EN HET AANBOD VAN

BEROEPSMILITAIREN

81

6.1. Het aanbod van potentiéle vrijwilligers $\quad 82$

6.2. Nederland en de uitvoering van VN-taken: 90

6.2.1. De organisatiestructuur 91

6.2.2. De taken 93

6.2.3. Opleiding 93

6.2.4. Werving en matching 94

6.2.5. Conclusies 96

6.3. Het wervings- en selectieproces 97

6.3.1. Het 'project 100.000' en de 'ASVAB-misnorming' 101

6.3.2. De vrouw in de krijgsmacht 106

6.4. De vraag naar beroepsmiliatiren 113

6.4.1. De mix van ervaren en onervaren militairen 114

6.4.2. Dienstplicht en de dood 117

6.4.3. Rangen en beloningen $\quad 120$

$\begin{array}{ll}\text { 6.5. Slotopmerkingen } & 127\end{array}$

7. DE WISSELWERKING TUSSEN MAATSCHAPPIJ EN $\begin{array}{ll}\text { KRIJGSMACHT } & 129\end{array}$

7.1. Het korps officieren 131

7.2. De privatisering van defensie 135

7.2.1. Privatisering: de theorie 136

7.2.2. De privatisering van de krijgsmacht 140

7.3. Conclusies 151 
8. DE OVERGANG VAN EEN DIENSTPLICHTIGENLEGER NAAR EEN VRIJWILLIGERSLEGER

8.1. De keuze tussen een dienstplichtigenleger en een 154

8.2. De overgang van een dienstplichtigenleger naar 158

8.3. De overgang van een gecentraliseerde krijgsmacht $\quad 162$

$\begin{array}{ll}\text { 8.4. naar een gedecentraliseerde krijgsmacht } & \\ \text { De mobilisabele eenheden } & 165\end{array}$

8.5. De cultuur van de krijgsmacht $\quad 167$

$\begin{array}{ll}\text { 8.6. Slotopmerkingen } & 171\end{array}$

9. SOCIALE DIENSTPLICHT 173

9.1. Inleiding 173

9.2. Sociale dienstplicht: de theorie $\quad \mathbf{1 7 4}$

9.3. Sociale dienstplicht: de uitvoerbaarheid 182

$\begin{array}{ll}\text { 9.4. Conclusies } & 184\end{array}$

10. SAMENVATTING EN CONCLUSIES

Summary 195

$\begin{array}{ll}\text { Literatuuropgave } & 199\end{array}$

$\begin{array}{ll}\text { Namenregister } & 207\end{array}$

$\begin{array}{ll}\text { Zakenregister } & 209\end{array}$ 



\title{
Economie en dienstplicht
}

\begin{abstract}
"Economics is the science which studies human behavior as a relationship between ends and scarce means which have alternative uses". Lionel Robbins, An Essay on the Nature and Significance of Economic Science, London 1962, blz. 16.
\end{abstract}

Militaire dienstplicht is een maatschappelijk fenomeen, dat vanaf de Napoleontische tijd in Nederland aanwezig is. Dienstplicht is een ingewikkeld fenomeen. Een aantal commissies heeft zich in Nederland met de dienstplicht beziggehouden, doch zij zijn niet tot het oordeel gekomen de dienstplicht te laten verdwijnen. In tegenstelling tot vele andere problemen in onze samenleving heeft de dienstplicht echter niet veel in de belangstelling gestaan. Pas in de laatste decennia van deze eeuw is er ook in wetenschappelijk opzicht belangstelling gekomen voor de dienstplichtige militair.

Economen in Nedlerland hebben zich vrijwel niet met de dienstplichtmaterie beziggehouden, hoewel zij toch af en toe refereerden aan de dienstplicht als voorbeeld van een belasting in natura, ${ }^{1}$ dit in navolging van Rudolf Goldscheid die in zijn "Staatssozialismus oder Staatskapitalismus" de dienstplicht reeds als een belasting in natura behandelde. ${ }^{2}$

Militaire dienstplicht is niettemin een economisch zeer relevant onderwerp, wat ons reeds duidelijk is gemaakt door Adam Smith in "The Wealth of Nations". ${ }^{3}$

In "The Wealth of Nations" legt Smith uit dat de kosten van een leger" verschillen, afhankelijk van de tijd waarin eenieder leeft. In de periode dat de wereld slechts door" jagers werd bewoond, kostte een leger vrijwel niets, omdat de aard van de werkzaamheden voor de jagers niet veranderde indien zij ten strijde trokken. Hetzelfde gold voor de herders. Als herders oorlog gingen voeren verhuisde de gehele bevolking mee en waren zodoende hun leider niet tot een extra last. Na de herders kwamen de boeren. Boeren met een klein bedrijfje konden gemakkelijk omgevormd worden tot soldaten. Hoewel een boer uitgerust moest worden met be-

\footnotetext{
1 In het literatuuronderzoek zijn slechts 2 artikelen over de dienstplicht met een economische basis van

Nederlandse schrijvers naar boven gekomen if. Volten, "Dienstplicht, legerworming en de Nederlandse economie, Economisch Statistissche Berichten, ni. 2577, 25-01-1967 en C.B.A. Spil, "Eein economische verklaring van de dienstplicht" "Economisch Statistische Berichten, $\mathrm{nr}_{2}$ 2553, 10-08-1966. Beide artikelen worden aangehaald door P.G.A. van Bergeiik, Economie van de Oorlog, Rotterdam, 1986.

Een voorbeeld van de bewering dat dienstplicht een belasting in natura is, vinden we bij: L.G.M. Stievens, Elementair belastingrecht, Deventer, 1989 , blz. 14 .

${ }^{2}$ R. Goldscheid, Staatssozialismus oder Statatskapitalismus: ein finanzoziologischer Beitrag zur Lossung des Statatschulden-Problems, Wien, 1917, hoofdstuk 1.

${ }^{3}$ Adam Smith, The Wealth of Nations, New York 1937, Book V, Chapter 1, blz. 653-669.
} 
scherming en bewapening waren de kosten voor de samenleving waar deze boer uit voort kwam niet erg hoog, indien de oorlog begon na de zaaitijd en afgelopen was voordat de oogst begon. De natuur kon hier haar werk doen, zonder dat de boer met zijn handen diende bij te dragen aan het welslagen van de oogst en hij zijn handen vrij had voor het voeren van een oorlog. Dit ligt anders bij een ambachtsman, zoals een smid of een timmerman. Indien zo lemand zijn werkplek verlaat, zal zijn bron van inkomsten opdrogen. De natuur doet niets voor hem. Hij moet het allemaal zelf doen.

In de loop der eeuwen is oorlogvoering steeds ingewikkelder geworden. Was zij eerst niet meer dan een eenwoudige schermutseling, in latere eeuwen bestond een oorlog uit verschillende campagnes die een groot deel van het jaar voortduurden. Hierdoor werd het noodzakelijk dat de staat die mensen zou moeten onderhouden die de oorlogen uitvochten, omdat het verlies aan inkomen voor henzelf te groot zou worden.

De ingewikkeldheid van de moderne oorlogvoering heeft haar oorsprong in de technologische vooruitgang. Oorlogvoering is gericht op het voortbrengen van gevechtskracht. Gevechtskracht welke tot stand wordt gebracht door de combinatie van kapitaal en arbeid, waarbij onder de component kapitaal zowel fysiek als menselijk kapitaal begrepen dient te worden. Indien het technologische proces vooruit gaat kunnen verschillende effectieve vormen van gevechtskracht tot stand worden gebracht. Dit kan echter alleen indien de mens zich deze ingewikkelde vormen van gevechtskracht eigen maakt door middel van scholing. De stand van de techniek maakt uit in welke mate van perfectie een oorlog gevoerd kan worden. Om deze perfectie te kunnen bereiken, is het echter wel noodzakelijk dat oorlogvoering de enige en principiële bezigheid is van een specifieke groep burgers, daar de verdeling van arbeid ook voor de oorlogvoering de beste methode is om haar prestaties te verbeteren.

Met de vooruitgang van de maatschappij heeft de mens de neiging gekregen zich van de oorlogvoering af te wenden. In zo'n samenleving zijn er twee methoden om er voor te zorgen dat de staat toch verdedigdl wordt, indien dit noodzakelijk is. In "The Wealth of Nations". worden deze twee methoden als volgt omschreven:

"There are only two methods of providing for defence. It may either, first, by means of a very rigorous police, and in spite of the whole bent of the interest, genius and inclinations of the people, enforce the practice of military exercises, and oblige either all the citizens of the military age, or a certain number of them, to join in some measure the trade of a soldier to whatever other trade or profession they may happen to carry on.

Or secondly ${ }_{n}$ by maintaining and employing a certain numbers of citizens in the constant practice of millitary exercises, it may render the trade of a soldier a particular trade, separate and distinct from all others.

If the state has recourse to the first of those two expedients, its military force is said to consist in a militia; if to the second, it is said to consist in a standing army. The practice of military exercises is the sole or principal occupation of the soldiers of a standing army, and the maintenance or pay which the sitate affords them is the principal and ordinary fund of their subsistence. The practice of military exercises is only the occasional occupation of the soldiers of a militia, and they derive the principal and ordinary fund of their subsistence from some other occupation. In a millita, the character of the labourer, artificer, or tradesman, predominates over that of the soldier: in a standing army, that of the sollder predominates over every other character; and in this distinction seems to consist the essential difference between those two different species of millitary force. ${ }^{\text {"4 }}$

4Smith, op cit., bliz, 659 
In een staand- of vrijwilligersleger wordt de soldaat betaald door de staat en is oorlogvoering een professionele bezigheil. De salarissen van de soldaat worden door de overige leden van de samenleving gedragen in de vorm van belastingen.

In een militia of dienstplichtigenleger bestaat het beroep soldaat in principe niet, maar is de oorlogvoering een tijdelijke bezigheid door mensen die feitelijk een ander beroep hebben. De staat betaalt de dienstplichtigen geen salaris, zodat zij ook geen belasting behoeft te heffen om de salarissen te betalen. De kosten van de oorlogvoering worden gedragen door de dienstplichtigen, omdat zij ziet in staat zijn gedurende de oorlog hun normale inkomen te verwerven.

Volgens Adam Smith is een dienstplichtigenleger technisch altijd inferieur aan een vrijwilligersleger omdat:

"The soldiers, who are exercised only once a week, or once a month, can never be so expert in the use of their arms, as those who are exercised every day, or every other day; and though this circumstance may not be of such consequence in modern, as it was in ancient times, yet the acknowledged superiority of the Prussian troops, owing, it is said, very much to their superior expertness in their exercise, may satisfy us that it its, even at this day, of very considerable consequence.

The soldiers, who are bound to obey their officer only once a week or once a month, and who are at all other times at liberty to manage their own affairs their own way, without being in any respect accountable to him, can never be under the same awe in his presence, can never have the same disposition to ready obedience, with those whose whole life and conduct are every day directed by him, and who every day even rise and go to bed, or at least retire to their quarters, according to their orders. In what is called discipline, or in the habit of ready obedience, a militia must always be still more inferior to a standing army, than it may sometimes be in what is called the manual exercise, or in the management and use of its arms. But in modern war the habit of ready and instant obedience is of much greater consequence than a considerable superiority in the management or arms." 5

Smith voegt daaraan toe dat een dienstplichtigenleger dat een aantal malen deelgenomen heeft aan een campagne, beschouwd kan worden als een vrijwilligersleger.

\section{$\S 1.1$. Dienstplicht en belastingheffing}

Uit "The Wealth of Nations" kunnen we opmaken dat de kosten van oorlogvoering samenhangen met de alternatieve bezigheden van diegenen die de oorlog moeten voeren. De economische wetenschap heeft hier het begrip "opportunity costs" voor. Daarnaast nemen de kosten van oorlogwoering toe naarmate de samenleving zich meer ontwikkelt. Bovendien wordt met de ontwikkeling van de maatschappij de oor logvoering ook ingewikkelder. In de tijd van de jagers werd slechts met speren gevochten, in onze tijd is dat toch wel even anders.

$\mathrm{Bij}$ de voorbereiding op een oorlog en het voeren van die oorlog is de grootte van de gevechtskracht van het leger een belangrijke variabele. Gevechtskracht is een combinatie van kapitaal (speren, schilden, scholing, boten, vliegtuigen, etc.) en arbeid, waarbij arbeid geleverd kan worden door vrijwilligers of dienstplichtigen. De kosten van arbeid bij een vrijwilligersleger worden gedragen door de samenleving in de vorm van belastingen, bij een dienstplichtigenleger is er sprake van een belasting-innatura ter grootte van de alternatieve opbrengsten van het werk dat de dienstplichtigen hadden kunnen verrichten indien zij niet in het leger hadden gezeten.

Vanuit een economische optiek is militaire dienstplicht een belasting-in-natura, Dienstplicht is een gedwongen bijdrage zonder dat daar een directe tegenprestatie

5 Smith, op cit. ble. 661. 
door de ontvanger van de bijdrage tegenover staat. Uit deze definitile kunnen een aantal vragen worden afgeleid. "Hoe groot is deze belasting-in-natura, wat zijn de kosten om deze belasting te innen, in hoeverre worden deze belastingen ontweken en ontdoken en wat is de "totale excess-burden' van deze belasting".

Dienstplicht is een belasting op arbeid. Een belasting op een specifiek goed betekent dat de relatieve prijsverhouding tussen de verschillende inputfactoren verandert. De allocatie in de krijgsmacht wordt door de dienstplicht verstoord.

Militaire dienstplicht zorgt voor een bepaalde kostenstructuur birnen de krijgsmacht, omdat de dienstplicht te beschouwen is als een subsidie op arbeid voor de ontvanger van de subsidie: de krijgsmacht. Iedere subsidie zorgt ervoor dat het gebruik van het goed dat gesubsidieerd wordt toeneemt. In de krijgsmacht heet dit goed de jonge militär. Dienstplicht stimuleert de krijgsmacht goedkope militairen in dienst te nemen, waardoor er relatief veel mensen, militairen en onervaren jongeren in dienst zijn.

Door de relatieve prijsverandering als gevolg van de dienstplicht ontstaat er bovendien een "excess-burden", een welvaartsverlies bovenop en naast de grootte van de belasting-in-natura die de dienstplicht reeds is.

\subsection{De visie op de samenleving}

De economische wetenschap ziet de dienstplicht als een belasting-in-natura. Toch wordt dit niet door iedereen als vanzelfsprekend aangenomen. Of dienstplicht inderdaad als een bellasting-in-natura beschouwd wordt, is veelal verbonden met de zienswijze die we hebben op de relatie tussen het individu en de staat, waar dit individu deel vanuit maakt, en hoe de staat dient te functioneren in de samenleving.

Politicologen hebben in de relatie tussen individu en staat twee grote benaderingswijzen kunnen onderscheiden ${ }^{6}$. In de organische visie op de staat, wordt de staat gekarakteriseerd als een natuurlijk organisme. Teder individu is een deel van dit organisme en de overheid kan worden beschouwd als het hart van dit organisme. Het individu heeft slechts bestaansrecht als deel van de staat en het welzijn van een individu is rechtstreeks gerelateerd aan het welzijn van de staat. Indien het goed gaat met de staat, gaat het ook goed met het individu. In de organische visie is het individu dus ondergeschikt aan de staat. Zo was in de Republiek van Plato een aktiviteit van een individu slechts wenselijk, indien deze bijdroeg aan een "rechtvaardige" matschappij.

Bij de keuze tussen een dienstplichtigenleger en een vrijwilligersleger staan in de organische visie op de staat de doeleinden van de staat dus voorop. Indien in die doeleinden slechts financiële parameters omschreven staan, is de dienstplicht dus te prefereren boven een vrijwilligersleger, omdat de dienstplicht de staat minder kost dan een vrijwilligersleger. Bovendien zal het met de dienstplichtige ook goed gaan, omdat met het dienstplichtigenleger beter tegemoet kan worden gekomen aan de doeleinden van staat dan met een vrijwilligersleger. Gaat het goed met de staat dan zal het ook well goed gaan met de dienstplichtige.

Tegenover de organische visie op de staat, staat de mechanische visie. In deze visie is de overheid niet het hart van de samenleving, maar is de overheid samengesteld door alle individuen in deze samenleving om er voor te zorgen dat al hun individuele doelen bereikt worden. De overheid dient die collectieve voorzieningen tot stand te brengen, wartoe een individu eigenhandig of in een kleine groep niet toe in staat is.

Gin deze wordt de visie gevolgd van Harvey S. Rosen in zijn boek Publie Finance, Homewood, 1988, blz. 4-8. 
Het individu stat in deze visie in het middelpunt van de belangstelling en niet de overheid of een zogenoemde sociale planner die de taak van de overheild overneemt.

In de mechanische visie is de dienstplicht wel degelijk een belasting voor de samenleving. Deze last komt welliswaar niet terug in de boekhouding van de overheid, maar is de samenleving wel tot last, omdat de individuen die de dienstplicht ondergaan dit als een last zullen ervaren. In de mechanische visie bestaat de overheid voor het welzijn van de mensen. Dit is tevens de visie welke in ons land door een groot aantal mensen wordt hoog gehouden en waar in dit proefschrift verder ook van wordt uitgegaan?.

Indien we accepteren dat de overheid bestaat woor het welzijn van de mensen, blijven we zitten met het probleem wat welzijn nu precies is en hoe de overheid dit welzijn moet bevorderen. In de economische wetenschap is een deelgebied anwezig dat zich met dit probleem bezighoudt, de welvaartseconomie. De welvaartseconomie is een economische theorie over de sociale wenselijkheid van alternatieve economische situaties ${ }^{8}$.

\section{\$1.3. De welvaartseconomie en het welzijn van dienstplichtigen}

Een analyse van de welvaartseconomie ${ }^{9}$ "welke normatief geladen is, begint mett een simpele economie van twee personen, die twee goederen consumeren bij een gegeven produktie van deze twee goederen. Het enige economische probleem is hier de allocatie van de twee goederen over de twee personen. Zo simpel als dit model lijkt, zo gemakkelijk zijn de belangrijkste resultaten van dit model ook toepasbaar in een wereld met vele mensen en goederen. ${ }^{10} \mathrm{De}$ twee-bij-twee analyse is hier gekozen vanwege haar eenvoud.

De twee mensen zijn Hans en Leo, en de twee goederen zijn bewaking en scholing. De verdeling van de hoeveelheid bewaking en sclioling tussen Hans en Leo wordt weergegeven met behulp van een Edgeworth Box. ${ }^{11}$ In figuur 1.1. stelt de lengte van de Edgeworth Box, $O s$, de totale hoeveelheid bewaking beschikbaar in de economie weer, terwijl de hoogte, Or, de hoeveellheid scholing voorstelt. De hoeveelheid goederen die Hans consumeert wordt gemeten door de afstand vanaf punt $O$; de hoeveellheid die Leo consumeert wordt gemeten door de afstand vanaf punt $O^{\prime}$.

Indien we veronderstellen dat zowel Hans als Leo beschikken over een set conventionele indifferentiecurven, die hun voorkeur voor bewaking en scholing weergeven, kunnen we deze indifferentiecurven inpassen in figuur 1.1. Hans is "gelukkiger" met indifferentiecurve $H_{3}$ dan met $H_{2}$ of $H_{1}$ en Leo is "gelukkiger" met indifferentiecurve $L_{3}$ dan met $L_{2}$ of $L_{1}$.

De volgende veronderstelling is dat er een arbitraire verdeling van bewaking en scholing is bepaald - zoals $G$ - in figuur 1.2., waarbij Hans beschikt over $O x$ bewaking en $O u$ scholing en Leo beschikt over $O^{\prime} y$ bewaking en $O^{\prime} w$ scholing. Hierbij is $H_{g} H_{z}$

\footnotetext{
7 Dit betekent niet dat iedereen in Nederland de mechanische visie op de staat huldigt. In het vervolg van het proefschrift wordt wel met de mechanische viste verder gegaan. Dit is en nomatieve kouze.

8 Rosen, biz. 40 .

9 Deze analyse is nader witgelegd in Rosen, blz, 38 en verder.

10 Zie woor een wiskundige afleiding wan dle algemene geldigheid van dit model onder andere hoofdstuk 11 uit Henderson en Quandt, Micro-economic Theory: a Mathematical Approach, New York 1980.

11 Genoemd naar de grote 19 ie-euwse economist F.Y. Edlgeworth.
} 
de indifferentiecurve van Hans en $L_{g} L_{g}$ de indifferentiecurve van Leo. Vervolgens kunnen we ons de vraag stellen of het mogelijk is om de hoeveelheid bewaking en scholing zo te herschikken dat Leo beter af is, terwijl de situatie voor Hans niet verslechtert. Indien we punt - $j$ - nemen, zien we dat Leo beter af is, omdat indifferentiecurve $L_{j} L_{j}$ een hoger nut vertegenwoordigt dan indifferentiecurve $L_{g} L_{g^{\prime}}$ terwijl Hans op zijn oude indifferentiecurve $H_{g} H_{g}$ blijft.

Hoever kan Leo's welzijn verder worden vergroot, zonder dat Hans er op achteruit gaat?

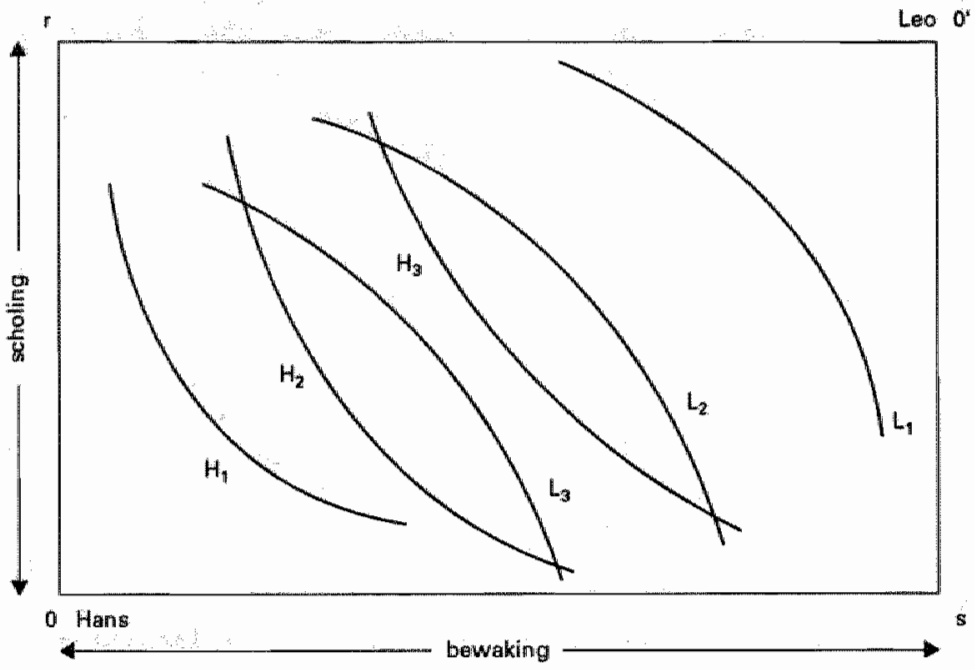

figuur 1.1 Indifferentimeurven in een Edgeworth Box

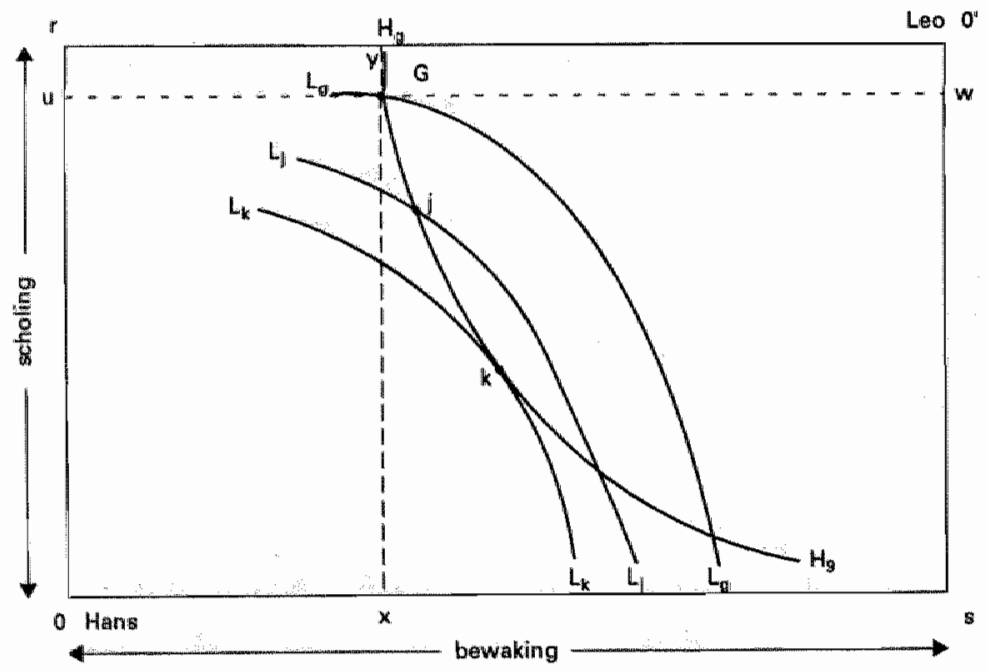

figuur 1.2 Parato afficiéntie: 
In figuur 1.2. kannen we zien dat dit proces kan blijven doorgaan tot dat punt - $k-$ is bereikt en Leo's indifferentiecurve die van Hans $(H, H)$ net raakt. Een allocatie zoals in punt - $k$ - wordt een Pareto-efficient punt 12 genoemd, omdat het welzijn van Leo slechts verbeterd kan worden door Hans slechter af te doen zijn. Pareto-efficientie wordt in de economische wetenschap vaak gebruikt als de standaard om de wenselijkheid van een allocatie van middelen te evalueren. Indien een allocatie niet Paretoefficient is, is dat in principe een verspilling van middelen, omdat het mogelijk is iemands welzijn te verhogen zonder iemand anders pijn te doen. Een Pareto-verbetering is dan ook een herallocatie van goederen, die er voor zorgt dat lemand beter wordt zonder de andere te benadelen.

Punt - $k$ - is niet het enige Pareto-fficiënte punt, dat we hadden kunnen bereiken vanuit punt $-g-$ Zo zijn in figuur 1.3. $k_{1}$ en $k_{2}$ Pareto-efficiente punten en indien we de gehele Edgeworth Box bezien, kunnen we een hele serie Pareto-efficiënte punten waarnemen. De slinger van alle Pareto-efficiënte punten noemen we een contractcurve. De contractcurve zit zo in elkaar dat bij alle punten op de contractcurve de marginale ruilvoeten van bewaking voor scholing van Hans en Leo gelijk zijn aan elkaar.

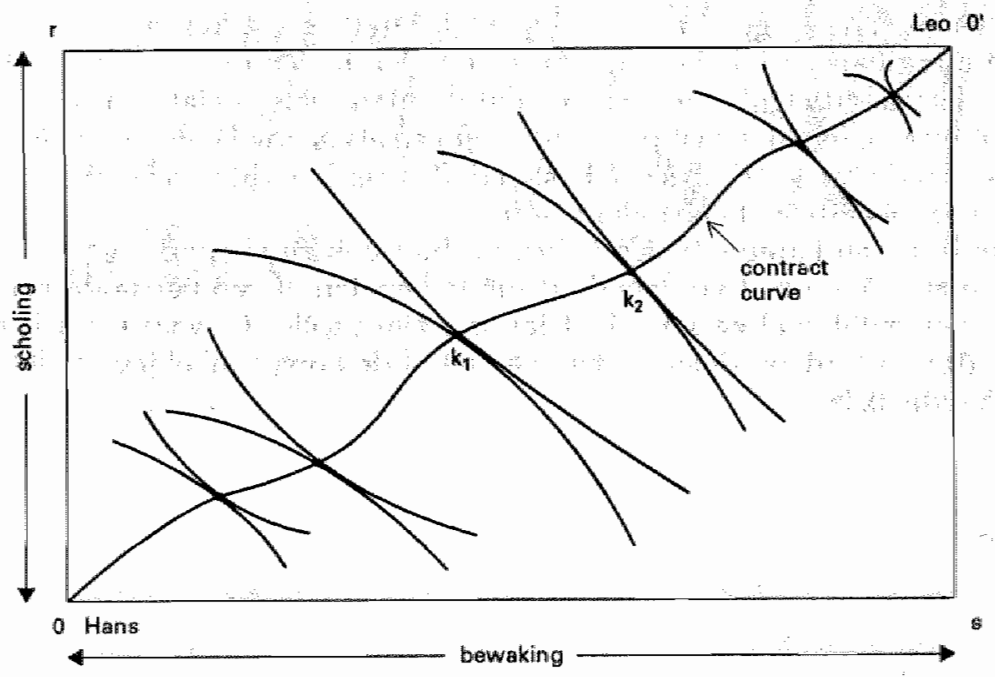

Higuur 1.3 De contract curve

De analyse heeft tot dusver verondersteld dat de produktie en daarmee het aanbod van bewaking en scholing constant is. Indien we de produktie variabel maken, is het de vraag wat er gebeurt met de voprwaarden voor een. Pareto-efficiënte verdeling. Pareto-efficiëntie is wel degelijk mogelijk onder een vatiabele produktie, maar dit betekent wel dat de voorwaarden hiervoor uitgebreid dienen te worden. Naast gelijkheid in de marginale substitutieverhouding van bewaking en scholing, dient er voor

12 Genoemd naar de grote $19 \mathrm{e}-\mathrm{e}$ euwse economist Wilfredo Pareto. 
Pareto-efficiëntie ook gelijkheid te zijn van de marginale substitutieverhoudingen aan de marginale transformatieverhouding van bewaking en scholing. De marginale transformatieverhouding geeft daarbij aan in welke verhouding bewaking kan worden omgezet in scholing. Indien we deze marginale transformatieverhouding uitdrukken in termen van marginale kosten, weten we wat de incrementele kosten van één extra eenheid bewaking of scholing zijn en kunnen we de voorwaarden voor Pareto-efficiêntie interpreteren in termen van marginale kosten.

De noodzakelijke yoorwaarde voor Pareto-efficièntie is nu dat de verhouding in marginale kosten tussen bewaking en scholing gelijk moet zijn aan de marginale substitutieverhouding van bewaking en scholing. Bij de beschrijving van de noodzakelijke voorwaarden yoor Pareto-efficiëntie hebben we echter nog geen indicatie of in een reële economie deze blijkbaar gewenste situatie ook bereikt wordt. Zal een marktsysteem op een natuurlijke wijze de contractcurve bereiken?

Het Eerste Fundamentele Theorema van de Welvaartseconomie voorziet hierbij in een antwoord. Zij stelt dat zolang producenten en consumenten handelen als volkomen concurrenten, dat wil zeggen prijzen als gegeven nemen, onder bepaalde voorwaarden een Pareto-efficiënte allocatie van middelen zal verschijnen. Deze voorwaarden luiden dat de prijzen van goederen gelijk moeten zijn aan hun marginale kosten, waarbij concurrentie verzekert dat aan deze voorwaarde wordt voldaan. De marginale kosten van een goed zijn daarbij gelijk aan de extra kosten voor de maatschappij, de marginale sociale kosten ${ }_{x}$ om te voorzien in één extra eenheid van datzelfde goed. Pareto-efficiëntie vereist dus dat de marginale sociale kosten van een goed worden weerspiegeld in zijn prijs. Indien er een afwijking is tussen de marginale sociale kosten en de marginale fysieke kosten of de prijs kan dit dus betekenen dat er maatschappelijk niet efficiënt gehandeld wordt.

Het criterium van Pareto-efficiëntie heeft echter ook zijn beperkingen. Dit komt omdat Pareto-efficiëntie niet voldoende is om te bepalen of een bepaalde verdeling van goederen eigenlijk wel gewenst is. Hiervoor zijn expliciete waardeoordelen nodig. Zonder deze waardeoordelen weten we niet of de oorspronkelijke verdeling inderdaad ook redelijk is.

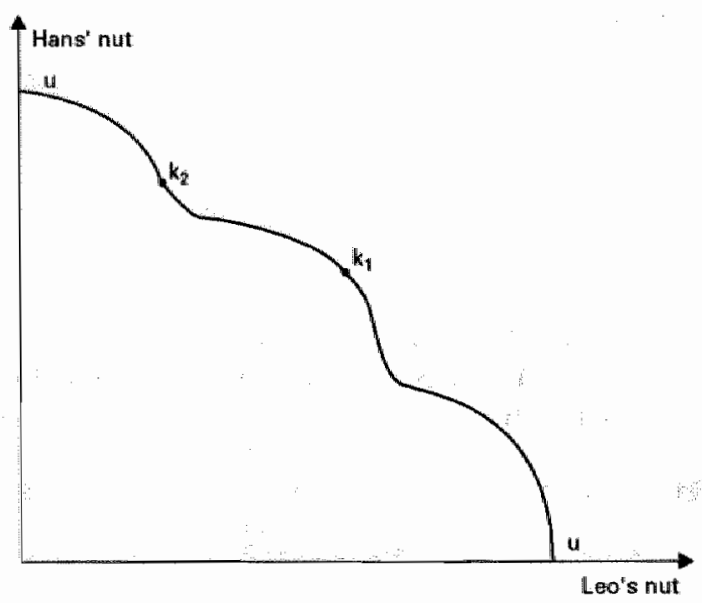

figutur 1.4 De nutsmagelijkhedencurve 
Indien we teruggaan naar de contractcurve van figuur 1.3. zien we dat de contractcurve impliciet een relatie weergeeft tussen het welzijn van Leo en Hans. Indien het welzijn van Leo hoog is, is dat van Hans laag, en omgekeerd. In figuur 1.4. is het nut van Leo op de horizontale as weergegeven en het nut van Hans op de verticale as. De curve $U U$ is de nutsmogelijkhedencurve en is afgeleid van de contractcurve. De punten $k_{1}$ en $k_{2}$ komen overeen met de punten $k_{1}$, $k_{2}$ van de contractcurve in figuur 1.3. Alle punten op of onder de nutsmogelijkhedencurve kunnen door Leo en Hans, of breder gesteld de gehele samenleving, bereikt worden, waarbij alle punten op de UUcurve Pareto-efficiënt zijn, maar wel verschillen in welzijn representeren. Welk punt is nu eigenlijk het beste punt?

De conventionele wijze om hier een antwoord op te geven, is de aanname van een sociale welvaartsfunctie. Deze sociale welvaartsfunctie $(W)$ geeft de maximaal haalbare maatschappelijke welvaart weer en is opgebouwd uit de individuele consumenten en kiezersvoorkeuren $(u)$.

(1.1) $W=F(u H, u L)$

Als gevolg van deze definitie ${ }^{13}$ is er in de sociale welvaartsfunctie geen plaats voor elitepreferenties, paternalisme of machtstreven en staat het belang van alle individuen tezamen voorop. Daarbij maakt het niet uit of het nu gaat om dienstplichtigen, algemene belastingbetalers, ambtenaren, bestuurders enz. De samenleving is beter af als $W$ in zijn totaal toeneemt of in ons beperkte geval het welzijn van Leo vooruitgat zonder dat Hans er meer in welzijn op achteruit gaat. ${ }^{14}$ Net als een individuele nutsfunctie voor goederen leidt tot een stelsel van indifferentiecurven, zo zal een sociale welvaartsfunctie leiden tot een stelsel van sociale indifferentiecurven zoals weergegeven in figuur 1.5.15

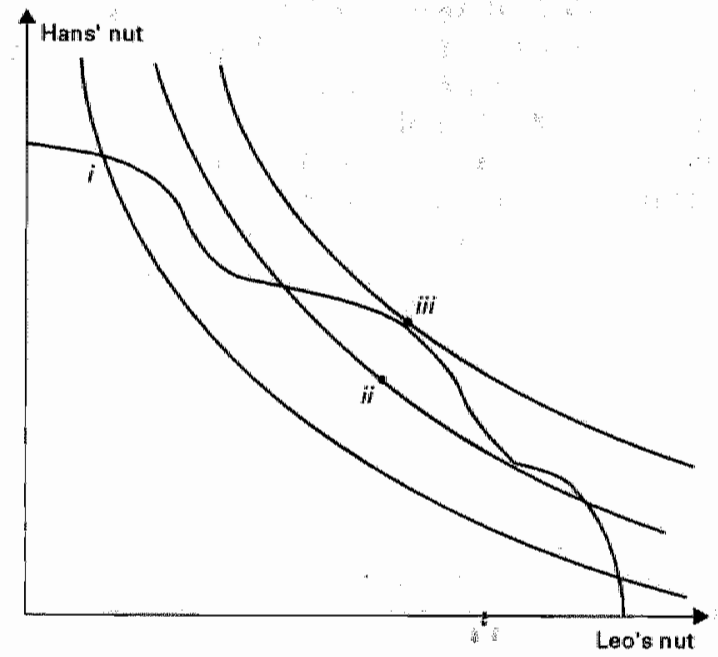

figur 1.5 Het maximalligeren wan socialle welvaart

\footnotetext{
13 Zie D. Wolfson, Publieke sector en economische orde, Groningen 1986, bliz. 33.

${ }^{14}$ Daarbij bekommeren we ons niet over het feit hoe de verschillende voorkeuren van Leo en Hans precies zijn ontstaan.

15 Sociale welvaartsfuncties die slechts afhangen van het nut van individien worden ook wel "ut"litaire" soctalle welvaartsfuncties genoemd, vanwege hun associatie met de $19 \mathrm{e}$ eeuwse utilitaristische filosofen.
} 
In figuur 1.5, is de nutsmogelikhedencurve samengevoegd met een stelsel van sociale indifferentiecurven. Uit deze figuur kunnen we afleiden dat punt - $t$ - riet zo gewenst is als punt - $i t$-, terwijl dat laatste punt in tegenstelling tot punt - $i$ - niet Pareto-efficiënt is. Punt - it - ligt op een hogere indifferentiecurve en is daarom te prefereren boven punt - $i-$ Daarbij makt het niet uit dat punt - it - niet-Pareto-efficiënt is. In figuur 1.5. is punt - $i t$ - natuurlijk het beste punt. Dit punt is zowel Pareto-efficiênt als het meest "fair".

Indien we terug gaan naar het Eerste Fundamentele Theorema van de Welvaartseconomie, dan hebben we daar gezien dat een systeem met rolkomen concurrentie leidt tot een efficiënte allocatie. Echter, er is geen enkele reden om aan te nemen dat dit punt leidt tot een punt waar de sociale welvaart op een maximum is. Zelfs indien de economie een Pareto-efficiënte allocatie van goederen oplevert, kan overheidsingrijpen noodzakelijk zijn om een "redelijke" verdeling van het welzijn in de samenleving te bewerkstelligen.

Terug nu naar de militaire dienstplicht. Wat heeft de welvaartstheorie nu precies voor de militaire dienstplicht te betekenen? Belangrijk is hier te constateren dat wij in. een land leven, waar het welzijn van ieder afzonderlijk individu ons aan het hart gaat en dat geldt ook voor de individuele dienstplichtige. Het welzijn en de welvaart van de dienstplichtigen maakt deel uit van onze maatschappelijke welvaart en speelt dus een belangtijke rol bif de analyse naar de economische aspecten van de militaire dienstplicht. Wil er sprake zijn van een Pareto-efficiënte allocatie dan dienen we de sociale kosten van de dienstplichtigen in het verhaal te betrekken, Een Paretoefficiênte verdeling vereist nu eenmaal dat de marginale sociale kosten van de dienstplicht worden weerspiegeld in de prijs van dienstplichtigen. ${ }^{16}$ Nemen we het welzijn van de dienstplichtigen niet mee in de beschouwing dan is er sprake van een afwijking tussen marginale sociale kosten en marginale fysieke kosten en is er maatschappelijke inefficiëntie aanwezig. Daarnaast is de individuele benadering in de analyse heel belangrijk, omdat we door de analyse van de "opportunity costs" van de individwele dienstplichtige niet alleen de sociale kosten van de dienstplicht kunnen achterhalen, maar ook kunnen inzien inhoeverre de welvaartsposities van andere groepen individuen in de samenleving worden beinvloed door de dienstplicht.

Op basis van deze individuele benadering kunnen we vervolgens komen tot een maatschappelijke kosten-batenanalyse van de institutionele vormgeving van de personeelscomponent in de krijgsmacht. Of in meer economische bewoordingen kunnen we zeggen dat de analyse een micro-economische basis heeft en microeconomische instrumenten hanteert, die uiteindelijk uitmonden in een meer macroeconomische kosten-batenanalyse.

\section{\$1.4. Dienstplicht en schaarste}

Indien we het begrip welvaart nader bekijken, dan wordt ons nog een ander aspect van de economische dimensie van de militaire dienstplicht duidelijk. "Welvaart is de som van de individuele nutsbelevingen ontleend aan het omgaan met schaarse alternatief aanwendbare middelen." 17 Uit deze definitie springen vier elementen naar voren: (1) het subjectieve karakter van de welvaart als de som van de individuele

\footnotetext{
16 Zlo blad wjde 12 voor de witleg van het begrip marginale sociale kosten.

17 Wolfson, op cit, bliz 22 en verder.
} 
nutsbelevingen. "Welfare is in the mind" zei Pigou18, de grondlegger van de welvaartseconomie. In paragraaf 1.3 hebben we uitgebrelid gezien wat dit precies inhoudt; (2) het subjectieve nuttigheidsaspect komt tot witdrukking in de eis van de alternatieve aanwendbaarheid. Nuttigheid is een externe ruilvoet en dat veronderstelt dat er iets alternatief aan te wenden is, (3) ${ }^{19}$ het welvaartsbegrip heeft een open karakter. Het omvat iedere individuele nutsbeleving, ook als die ten koste gaat van eigen materieel gewin. Tenslotte (4) het gaat bovendien om schaarse middelen, want zonder schaarste is er geen kwestie van een keuzeprobleem en dus ook niet van het omgaan met alternatieven.

Dienstplicht botst met schaarste, omdat er bij dienstplicht voor de dienstplichtigen geen keuzevraagstuk is. Dienstplichtigen zijn namelijk verplicht tot het vervullen van hun militaire dienst.

De plicht heeft tevens tot gevolg dat de krijgsmacht de beschikking krijgt over een zeer grote hoeveelheid jongeren. Deze hoeveelheid jongeren is zo groot dat de krijgsmacht door de overvloedigheid vrijwel geen enkele prikkel heeft om deze jongeren te zien als schaarse middelen. Een dienstplichtigenleger is dan ook een krijgsmacht die de beschikking heeft over een "oneindig" aantal dienstplichtigen, waarbij het schaarste element van die dienstplichtigen heel zwak is of gewoon ontbreekt. ${ }^{20}$

De economische wetenschap heeft dan ook op het eerste gezicht moeite met de dienstplicht, omdat het centrale kernbegrip uit de economische wetenschap, de schaarste, ontbreekt. Lionel Robbins stelt:

"The economist studies the disposal of scarce means. He is interested in the way different degrees of scarcity of different goods give rise to different ratios of valuation between them, and he is interested in the way in which changes in ends or changes in means-from the demand side or the supply side-affect these ratios. Economics is the science which studies human behaviour as a relationship between ends and scarce means which have alternative uses.

Nu de dienstplicht de schaarste aan arbeidskrachten in de krijgsmacht voor een groot deel ter zijde schuift, kunnen we het gevoel krijgen dat dienstplicht een econoom niet zal boeien. Doch deze laatste redenering is een volkomen misvatting. De plicht ontzegt de maatschappij het alternatieve gebruik van bepaalde middelen, maar dat wil niet zeggen dat deze middelen niet alternatief aanwendbaar zijn. Ook de dienstplicht brengt kosten met zich mee. Buchanan citeert over het principe rond dit soort kosten Frank H. Knight:

"The opportunity cost notion is central . The cost of any alternative (simple or complex) chosen is the alternative that has to be given up; where there is no alternative to a given experience, no choice, there is no economic problem, and cost has no meaning. Economic cost ${ }_{i}$ then, consists in the renunciation of some 'other' use of some resource or resource capacity in order to secure the benefit of the use to which it is actually devoted. The only general-cost theory which can be maintained will, after all, be that of alternative costi, ........... 22

\footnotetext{
18 A.C. Pigou, The economics of welfare, London, 1962.

19 In Wolfson, bladzijde 26 is dit het wierde punt, doch hier zijn de punten 3 en 4 omgewilsseld.

20 Een vijwilligersleger is een krijgsmacht waath het personeel schaars 1 s, omdat de krijgsmacht niet de beschikking heeft over een in principe "oneindig" aantal dienstplichtigen Het schaarste element is dus heel siterk in ean vrijwilligersleger. Met de term dienstplichtigenleger wordt affeweken van de normale term kader-militielegrer, omdat het ontbreken van echte schaarste aan personeel zich doet gevoelen door de gethele organisatie en niet slechts in het dienstplichtigendeel. Om dezelfde reden wordt in het vervolg een kader-virijwilligersleger een vrijwilligersleger genoend.

21 Lionel Robbins, An Essay on the Nature and Significance of Economic Science, London 1962, blz. 16.

22. . M. Bucharan, Cost and Choice, Chicago, 1969, bli. 15.
} 
Ook centráal geleide economieën, zoals in Oost-Europa voor de val van de Berlijnse muur, zijn interessant voor economen en daar de dienstplicht een centraal geleid stelsel in de krijgsmacht introduceert is er geen reden het dienstplichtvraagstuk niet vanuit een economisch perspectief te benaderen. De economische wetenschap kan in deze aandragen hoe de situatie in de krijgsmacht had kunnen zijn, indien er binnen deze krijgsmacht daadwerkelijk schaarste had bestaan. Zij kan het alternatief aandragen en daarmee ook de "alternatieve kosten". Daarbij kijkt zij niet alleen naar de dienstplicht als arbeid op zich, maar ook naar de alternatieve prikkels die mensen binnen krijgsmacht krijgen als gevolg van het verschil tussen de aan- of afwezigheid van dienstplicht:

Schaarste introduceert concurrentie. Deze concurrentie hebben we nodig willen we überhaupt een Pareto-efficiënte situatie bereiken. Een krijgsmacht zonder schaarste kent de ingebouwde prikkels niet, die leven geven aan de "invisible hand" van Adam Smith. Dienstplicht kan daarom bijna niet anders leiden dan tot een situatie waarin Pareto-efficiëntie vrijwel onhaalbaar is en slechts bij toeval bereikt kan worden.

In een onderzoek naar de dienstplicht staat daarom de zoektocht naar de alternatieve schaarse situatie voorop. Een onderzoek dat begint met een analyse van de sociale kosten van dienstplicht om daarmee de marginale sociale kosten te kunnen achterhalen. Met deze marginale sociale kosten als uitgangspunt kan vervolgens een wereld met schaarste, in casu een vrijwilligersleger, verder geanalyseerd worden.

Tegenover de kosten van de dienstplicht staan de opbrengsten van de dienstplicht. Bij de opbrengsten van de dienstplicht gaat het niet alleen om de persoonlijke opbrengst voor de dienstplichtige, voor zover deze al aanwezig mocht zijn. De opbrengsten van de dienstplicht moeten vooral op meso- en macro-economisch niveau worden gezocht. Door de dienstplicht komen vele jongens met allerlei achtergronden en uit diverse streken van het land in aanraking met andere culturen en gewoonten. Door dit contact kunnen velerlei leereffecten ontstaan die na de diensttijd weer worden meegenomen naar familie en eigen streek. Door de dienstplicht ontstaat een integratie van de samenleving, die vooral in een samenleving zonder veel andere communicatiemogelijkheden niet snel tot stand zou kunnen komen. Dienstplicht zorgt voor een wisselwerking tussen de verschillende delen in de maatschappij, zowel voor bepaalde groepen in de samenleving als voor bepaalde landstreken in de samenleving.

Dienstplicht zorgt tevens voor een wisselwerking tussen maatschappij en krijgsmacht. Bij een analyse van de dienstplicht moet dan ook hier op zoek worden gegaan naar de implicaties van de altematieve schaarse situatie, waarin de dienstplicht niet meer bestaat. Adam Smith zegt in "The Wealth of Nations" het volgende over de wisselwerking tussen maatschappij en krijgsmacht:

\footnotetext{
"Men of republican principles have been jealous of a standing army as dangerous to liberty is so, wherever the interest of the general and that of the principal officers are not necessarily connected with the support of the constitution of the state. The standing army of Ceasar destroyed the Roman republic. The standing army of Cromwell turned the long parliament out of doors. But where the sovereign is himself the general, and the princlpal nobility and gentry of the country the chief officers of the army; where the military is placed under the command of thase who have the greatest interest in the support of the civil authority, because they have themselves the greatest share of that authority, a standing army can never be dangereous to liberty. The security which it gives to the sovereign renders unnecessary that troublesome jealousy, which, in some modern republics, seems to watch over the minutest actions, and to be at all times ready to disturb the peace of every citizin. Where the security of the magistrate, though supported by the principal people of the country, is endangered by every
} 
popular discontent; where a small tumult is capable of bringing about in a few hours a great revolution, the whole authority of government must be employed to suppress and punish every murmur and complaint against it. To a sovereign, on the contrary' who fieels himself supported, not only by the natural aristocracy of the country, but by a well regulated standing army, the rudest, the most groundless, and the most licentious remonstrances can give little disturbance. He can safely pardon or neglect them, and his consciousness of his own superiority naturally disposes him to do so. That degree of liberty which approaches to licentiousness can be tolerated only in countries where the sovereign is secured by a well-regulated standing army. It is in such countries only, that the public safety does not require, that the sovereign should be trusted with any discretionary power, for suppressing even the impertinent wantonness of this licentious liberty." 23

Smith staat hiermee lijnrecht tegenover de opvattingen van Machiavelli, die in zijn "Dell'arte delle guerra" 24 min of meer het omgekeerde betoogde. Machiavelli zag in een vrijwilligersleger juist een groot gevaar voor de maatschappij. De wisselwerking tussen maatschappij' en krijgsmacht en de problemen die met welke alternatieve vorm van de krijgsmacht dan ook te maken hebben, mag in een analyse van de militaire dienstplicht dus niet ontbreken, evenals het zusje van de militaire dienstplicht, de sociale dienstplicht en het nichtje de schoolplicht.

\section{$\$ 1.5$. De structuur van het proefschrift en de onderzoeksvragen}

Dienstplicht leidt tot een groot aantal vragen, welke in deze paragraaf nader uitgewerkt en toegelicht zullen worden. In de volgende hoofdstukken zal getracht worden de vragen uitgebreid te beantwoorden. Bij de beantwoording van de vragen zal een bepaalde structuur worden gevolgd. Deze structuur volgt uit de opbouw van hoofdstuk 1 en kan worden gesplitst in twee hoofdlijnen. De eerste lijn volgt de dienstplicht als belasting-in-natura, terwijl de tweede lijn de dienstplicht in het publieke besluitvormingsproces als onderwerp heeft. In de eerste lijn gaat het om vraagstukken als de ontwikkeling van dienstplicht als belasting-in-natura, de grootte van de dienstplichtbelasting, de "excess-burden" van de dienstplichtbelasting en de effecten van de schaarsteproblematiek die samenhangen met de dienstplicht, waarmee getracht zal worden de alternatieve kosten van de dienstplicht boven water te halen. Een lijn waarbij een micro-economische analyse centraal staat, zowel in de afzonderlijke hoofdstukken, als in het gehele proefschrift.

Met behulp van de uitkomsten van de zoektocht naar de alternatieve kosten kan het publieke besluitvormingsproces dan opnieuw bekeken worden. Hoofdvraag daarbij is in hoeverre een vrijwilligersleger de welvaartsposities van de verschillende individuen beïnvloedt, zoals daar zijn de dienstplichtigen, de algemene belastingbetaler, de individuen die een bepaalde waarde hechten aan de binding tussen maatschappij en krijgsmacht en, zoals ook verwoord door Adam Smith, de individuen die het technische en kwaliteitskarakter van de krijgsmacht benadrukken. De uitkomsten van al deze micro-economische analyses in beide lijnen zullen dan weer gebruikt worden in de maatschappelijke kosten-batenanalyse ten aanzien van de mogelijkheid een dienstplichtigenleger om te ruilę̣ voor een vrijwilligersleger.

Daar de militaire dienstplicht in oorsprong een samenstel van publieke rechtregels omhelst, valt de analyse van dit proefschrift onder het vakgebied van de "Law and Economics." Uit deze omschrijving kan worden afgeleid dat de analyse primair

\footnotetext{
23 smith, op cit, blz. 667 .

24Zie onder andere, M. L. Tiesinga, Dienstplicht van millitaire, naar sociale?, concepttrekst voor Armex Defiensie magazine, 1992.
} 
uitgaat van een juridische vraagstuk, dat vervolgens met economische methoden en technieken onderzocht wordt.

Door de speciale eigenschappen van de dienstplicht is het bovendien zo dat naast een rechtseconomische analyse ook de New Institutional Economics om de hoek komt kijken. Deze speciale eigenschappen hebben met name betrekking op het ontbreken van 'echte" schaarste in de krijgsmacht, door de wettelijke verplichting van jongeren om toe te treden tot deze kriygsmacht. De New Institutional Economics is met name gericht op de economische theorie en de verbetering van deze theorie. Daarbij richt zij zich voornamelijk op tot voor kort verwaarloosde onderwerpen in de economie, zoals het ontwerp en de keuze van bepaalde instituties.

Indien we de structuur van dit proefschrift vervolgens terugvertalen naar concrete vraagstukken, komen we tot de volgende onderzoeksvragen:

- (1) Militaire dienstplicht is een middel om te voorzien in arbeidskrachten voor de krijgsmacht. Een krijgsmacht die primair dient te zorgen voor de produktie van gevechtskracht, waarmee kan worden woorzien in de behoefte aan het collectieve goed defenisie. Welke economische aspecten zijn er eigenlijk verbonden aan het collectieve goed defensie en welke actoren komen er kijken bij een analyse van het collectieve goed defensie, aangezien dit goed tot stand komt met behulp van het budgetmechanisme en dus beïnvloed wordt door de actoren binnen het publieke besluitvormingsproces?

- (2) Militaire dienstplicht is een fenomeen dat niet uit de lucht komt vallen. Hoe is de dienstplicht in Nederland ontstaan, en zijn er ook economische verklaringen voor het bestaan van de milltaire dienstplicht? Tevens is daar de vraag aan gekoppeld waarom de militaire dienstplicht reeds zo'n lange tijd bestaat?

- (3) Dienstplicht is een belasting-in-ratura. Hoe groot is deze sociale last, hoe is deze last verdeeld en welke directe kosten zjin er nog meer verbonden aan deze belasting in natura?

- (4) Dienstplicht verstoort de allocatie in de krijgsmacht. Deze verstoring leidt tot verandering van relatieve prijzen en doet een 'excess burden' ontstaan. Hoe groot is deze 'excess-burden', en welk effect heeft dienstplicht op het gebruik van produktiefactoren in de krijgsmacht?

- (5) Het alternatief voor een dienstplichtigenleger is een vrijwilligersleger. Welke economische aspecten spelen een rol bij de samenstelling van een vrijwilligersleger? Hoe zien de taken van een vrijwilligersleger er uit en kan het marktmechanisme daadwerkelijk voorzien in de vulling van een vrijwilligersleger tegen maatschappelijk verantwoorde kosten of zijn madere richtlijnen daadwerkelijk noodzakelijk om te komen tot een effectieve en efficiènte krijgsmacht?

- (6) Welke alternatieven kunnen dienstplicht bij de wisselwerking tussen maatschapplj en krijgsmacht vervangen of zelfs verbeteren? In hoeverre kan de economische wetenschap daar een bijdrage aan leveren?

- (7) Indien een dienstplichtigenleger wordt vervangen door een vrijwilligersleger dient een reorganisatie van de krijgsmacht plaats te vinden. Is deze vervanging van een dienstplichtigenleger door een vrijwilligersleger wenselijk? Wanneer is de vervanging van een dienstplichtigenleger door een vrijwilligersleger mogelijk, hoe dient deze reorganisatie gestalte te krijgen en welke instrumenten zijn daarvoor noodzakelijk?

- (8) In tegenstelling tot militaire dienstplicht kent Nederland geen sociale dienstplicht. In hoeverre is militaire dienstplicht verwant met de sociale dienstplicht en kan bij een discussie over de sociale dienstplicht geleerd worden van de technieken die gebruikt worden om de millitaire dienstplicht te analyseren. Wat zijn de opbrengsten 
van militaire dienstplicht en is sociale dienstplicht een haalbaar alternatief, indien we de opbrengsten van de militaire dienstplicht in het verhaal betrekken? 


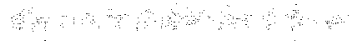

. 


\title{
Het collectieve goed defensie
}

\author{
"Strategy and cost are as interdependent as the front and rear sights of a rifle". \\ Charles J. Hitch en Roland N. McKean, The Economics of Defense in the Nuclear \\ Age, Cambridge, 1960, blz. 3.
}

\section{\$2.1. Defensie en economische theorie}

De militaire dienstplicht maakt onderdeel uit van de wijze waarop de inwoners van een samenleving zich willen beschermen tegen aanvallen van buitenaf. Met andere woorden, de militaire dienstplicht is onderdeel van het collectieve goed defensie.

Defensie is een collectief goed, omdat het onmogelijk is om degenen die niet willen betalen uit te sluiten (non-exclusiviteit) en omdat de aanspraken van eén persoon op defensie niet ten koste gaan van de aanspraken van een ander persoon (nonrivaliteit). Exclusiviteit en rivaliteit zijn de centrale begrippen in de theorie van de collectieve goederen. Deze theorie verklaart op grond van welke goederenkarakteristieken de markt als informatie-, bekostigings- en sanctiemechanisme verstek laat gaan en op grond van welke efficiëntiemotieven het derhalve verkieslijk kan zijn om bepaalde voorzieningen collectief te bekostigen. Bij het hanteren van de theorie van collectieve goederen en dus ook het collectieve goed defensie, gaat het om drie dingen': 1) Om voor ogen te krijgen op grond van welke goederenkarakteristieken en efficiëntiemotieven er besloten kan worden tot collectieve bekostiging (belastingheffing) van publieke voorzieningen.

2) Efficiëntie is niet het enige motief voor overheidsinterventie. Zo kunnen maatschappelijke en cultuur-politieke overwegingen, externe effecten, monopolies, kostenoverwegingen, en het total ontbreken van markten ook leiden tot inmenging van de overheid.

3) Bekostiging door de overheid betekent nog niet dat zij ook de produktie ter hand neemt.

Dat defensile uit de bellastingopbrengsten betaald wordt, heeft dus voornamelijk met de goederenkarakteristieken van het goed defensie te maken. Een individu kan defensie niet afwijzen als hij deze niet wenst, maar een individu is ook niet uit te sluiten van defensie. Defensie is niet-exclusief, omdat de levering van het collectieve goed defensie niet beperkt kan worden tot hen die bereid zijn de geldende marktprijs ervoor te betalen. Bovendien gaat de consumptie van én persoon van het goed defensie niet ten koste van de consumptie van een ander persoon van dat zelfde goed defensie. $\mathrm{Er}$ is dan ook geen sprake van rivaliteit, maar van "joint consumption". We kunnen ook zeggen dat de marginale kosten van een additionele eenheid consumptie van het

\footnotetext{
1D.J. Wolfson, Publieke sector en economische orde, Groningen, 1988, Blz. 46.
} 
goed defensie nul bedragen. In de gedachtengang van de prijsvorming op basis van marginale kostencalculatie zal de prijs dus nul moeten bedragen of, met andere woorden, gratis ter beschikking worden gesteld. In het geval van het collectieve goed defensie kunnen we daar nog aan toevoegen dat de behoefte aan dit collectieve goed wordt opgeroepen door de internationale veiligheidssituatie en niet door de behoefte van de consumenten voor dit goed op zich. De verticale aggregatie van individuele vraagcurven voor collectieve goederen, zoals dit is aangetoond door Samuelson ${ }^{2}$, is dan ook niet van toepassing voor het collectieve goed defensie.

Dit houdt echter wel in dat de bekostiging var defensie een moeilijke zaak wordt, daar "free-rider-gedrag" in dit geval niet te voorkomen is. De werkelijke voorkeuren voor het collectieve goed defensie komen door het "free-rider-gedrag" van de individuen niet boven tafel, waardoor er in zijn geheel geen collectief goed defensie tot stand zou kunnen komen. Daarom neemt de overheid de bekostiging op zich van dit collectieve goed.

De overheid heeft ook de produktie van het collectieve goed defensie ter hand genomen. Dit heeft echter een juridische oorzaak en geen economische. Op deze juridische oorzaak zal in \$2.2. nader worden ingegaan. Dat de overheid de produktie ter hand neemt betekent echter niet dat de economische wetten met betrekking tot de defensieproduktie ter zijde kunnen worden geschoven. ${ }^{3}$

Aanwending van produktiemiddelen in de defensiesector houdt een onttrekking van middelen aan de civiele maatschappij in, waar deze middelen relatief schaars zijn ten opzichte van voorkomende behoeften. Alleen al vanuit deze invalshoek zijn de produktiefactoren in de defensiesfeer derhalve schaars. Vanuit de defensieorganisatie word door sommigen beweerd, dat het gebruik van economische criteria bij de aanwending van de voor defensiedoeleinden beschikbare middelen slechts beperkt mogelijk is vanwege het specifieke karakter van het defensiebedrijf. Sommigen gaan in hun bewering zover, dat zij de noodzaak tot economisch handelen in de defensieorganisatie in twijfel trekken. Hitch en McKean zeggen echter:

\footnotetext{
"The problem of security might in theory be regarded as one big economic problem. The nation has certain resources - now and prospectivily in the future- which are conventionally classified by economists as various sorts of land, labor, and capital. These subjects can be used to satisfy many objectives of the nation and its individual citizens - national security, a high standard of living, social security, and a rapid rate of economic growth, and so on. These are, of course, competing objectives. In general the more resources the nation devotes to national security, the less it will have for social security and vice wersiant 4
}

Iedere organisathe probeert met behulp van de tot haar beschikking staande hoeveelheid kapitaal en arbeld een produkt tot stand te brengen. In de krijgsmacht zou deze produktie met de term gevechtskracht kunnen worden aangeduid. In de praktijk wordt de term gevechtskracht weinig gebruikt. Meestal wordt het produkt van de krijgsmacht weergegeven in termen van "inputfactoren", in casu het aantal soldaten, tanks, en gevechtsvliegtuigen. Correcter is echter het produkt van de krijgsmacht te omschrijven als: "Het verdedigen van de Noord-Duitse laagvlakte gedurende 100 da. gen" of "Het kunnen voeren van twee oorlogen in twee verschillende delen van de

\footnotetext{
2Paul A. Samuelson, The Pure Theory of Public Expenditure, Review of Economics and Statistics 36,1954, bli. 387389.

32 te voor esen uigebraide analyse: K.A.M. Bogaert, Aspecten van het economisch handelen in de militaire onganixat: $e_{1}$ Maandschrift exonomie, 1965 , ble 378-381.

${ }^{4}$ Charles J. Hitelh en Roland N. McKean, The Economics of Defense in the Nuclear Age., Cambridge „1960, blz 3.
} 
wereld, inclusief het voldoen aan 3 verzoeken van de Verenigde Naties inzake militaire bijstand".

Deze abstracte "output" wordt bepaald door de internationale veiligheidssituatie en het politieke besluitwormingsproces en niet door de krijgsmacht zelf. De krijgsmacht krijgt de opdracht het produkt "defensie" te produceren. De "output" van de krijgmacht mag dan buiten de markt om geschieden, voor wat betreft de "input" neemt de krijgsmacht wel degelijk deel an het maatschappelijk ruilproces.

Dit onderscheid is zeer wezenlijk, en wordt door Wolfson duidelijk naar voren gebracht in zijn derde punt bij de theorie van de collectieve goederen. De aanwezigheid van een zuiver collectief goed, zoals defensie, betekent dat de overheid de produktiekosten betaalt. Wie het collectief goed produceert is een vraag van een geheel andere orde. Ook bij zuiver collectieve goederen is dit niet anders. Dijken ter bescherming tegen de zee worden collectief bekostigd; maar aangelegd door particuliere aannemingsmaatschappijen.

Bij een door de internationale situatie en politieke besluitvorming bepaalde "output" komt een efficiënte krijgsmacht neer op het minimaliseren van de kosten van haar "inputs", kapitaal en arbeid. Ook bij de krijgsmacht dient doelmatigheid voorop te staan. Er mag maatschappelijk misschien een conflict bestaan over de vraag hoeveel geld te besteden aan de diverse maatschappelijke voorzieningen, indien eenmaal bepaald is hoeveel geld te besteden aan het collectieve goed defensie, is het zaak dit goed tegen minimale kosten voort te brengen. Ook al omdat er geen enkel conflict bestaat tussen militaire strategie, technologie om de gevechtskracht voort te brengen, en het efficiënt gebruik van middelen in de krijgsmacht. Hitch en McKean zeggen:

"There is a conflict between defense and other goods in deciding on the size of the military budget. Economizing involves deciding how much of other things to sacrifice in the inter est of military strength. But in decisions on how to spend the military budget on what kinds of equipment and forces to implement what kind of strategy - there is mo such conflict. Strategy, technology, and economy are not three independent "considerations" to be assigned appropriate weights, but interdependent elements of the same problem. Strategies are ways of using budgets or resources to achieve military objectives. Technology defines the possible strategies. The economic problem is to choose that strategy, including equipment and everything else necessary to implement it, which is most efficient (maximizes the attainment of the objective with the given resources) or economical (minimizes the cost of achieving the given objective) - the strategy which is most efficient also being the most economical" 5

Concluderend kunnen we stellen dat economische theorieen zonder meer toepasbaar zijn op de krijgsmacht en dat deze krijgsmacht zich dient te confontmenen aan de economische wetten. Doet zij dit niet dan is een inefficiente produktie haar deel, wat niet alleen gevolgen heeft voor de krijgsmacht zelf, maar tevens voor de gehele maatschappij.

\section{§ 2.2. Het geweldsmonopolie van de overheid}

Naast de bekostiging van het collectieve goed defensie neemt de overheid ook de produktie ter hand. Het collectieve goed defensie wordt geproduceerd door de krijgsmacht, bestaande uit de onderdelen Koninklijke Marine, Koninklijke Landmacht, Koninklijke Luchtmacht en Koninklijke Marechaussee. Zoals reeds in de vorige paragraaf naar voren $\mathrm{kwam}$, heeft dit een juridische oorzaak. Alleen de over-

5 Idem, blz. 3. 
heid is gerechtigd geweld te gebruiken. $Z \mathrm{Zj}$ is in het bezit van het geweldsmonopolie, aok wel zwaardmacht genoemd.

Binnen de krijgsmacht werken zowel burgers als militairen. Daamaast kan er binnen de krijgsmacht een duidelijk onderscheid worden gemaakt tussen gevechtsonderdelen en niet-gevechtsonderdelen. Dit onderscheid wordt de "teeth-to-tail-ratio" genoemd.

De tanden van de krijgsmacht zijn die onderdelen die geacht worden geweld te gebruiken (gevechtsonderdelen) en de staart van de krijgsmacht bestaat uit die onderdelen (niet-gevechtsonderdelen), die een ondersteunende taak hebben in de produktie van het collectieve goed defensie. De overheid is noodzakelijk voor de gevechtsonderdelen, daar deze onderdelen geweld dienen te gebruiken. De overige ondersteunende onderdelen kunnen door burgers of particulier initiatief worden gedaan, daar aan deze taken geen geweldselement gekoppeld is. 6

Het hier gemaakte onderscheid tussen gevechtsfuncties te vervullen door militairen en niet-gevechtsfuncties te vervullen door burgers wijkt af van de "Regeling inzake het aanmerken van functies als organieke militaire- of burgerfuncties." Volgens artikel 2 van deze regeling, geldt dat:
"Als organieke militaire functies worden aangemerkt:
a. functies die als hoofd- of neventak de bediening van een wapen of een wapensysteem inhouden, dan wel daarmee in directe telatie staan;
b. functies waarvoor millitaire deskundigheid is vereist;
c. functies waaraan in buitengewone omstandigheden bevoegdheden ter uittoefening van het militaire gezag zijn of kunnen worden gedelegeerd of die in oorlogsomstandigheden millitaire gezagsverhou- dingen vereisen." 7

De functies onder a. genoemd zijn duidelijke gevechtsfuncties. De vraag is, waarom de functies onder $b$. en $c$ niet door burgers kunnen worden uitgeoefend. Uit de toelichting bil artikel 2 blijkt dat voor de functies onder b.:

"Onder militaire deskundigheid - die slechts kan worden verkregen door het doorlopen van een milli-
taire loopbaan - wordt verstaan een meer dan algemene kennis van personele en materiële middelen in
ruime ztn, alsmede de ervaring en de vaardigheden nodig om die middelen doeltreffend in te zetten". 8

Militaire deskundigheid is een objectief verschijnsel, dat verkregen kan worden door kenuis van de organisatie en de middelen in de organisatie. In de toelichting op artikel 2 wordt gesteld dat deze kennis slechts verkregen kan worden door het doorlopen van een militaire loopbaan. Toch zijn er in de wereld vele mensen die militaire deskundigheid hebben zonder dat zij een militaire loopbaan hebben vervuld Ook binnen de krijgsmacht zijn er vele mensen met militaire deskundigheid zonder dat zij militair zijn. Militaire deskundigheid wordt voornamelijk verkregen door het opnemen van kennis over de krijgsmacht, waarvoor geen millitaire loopbaan doorlopen hoeft te worden. Er hoeft dan ook niets in de weg te staan de functies onder $b$. in artikel 2 van de "Regeling inzake het aanmerken van functies als organieke militaire of burgerfuncthes" door burgers te laten vervullen.

\footnotetext{
"Er stat ther "kunnen worden gedaan", daar dit niet vanzalifsprekend is. De ondersteunende onderdelen moeten uitgewoerd worden door burgers of particuller initiatief, indien deze ook daadwerkellik goedkoper zijn dan mill tai ren. Anders zouden deze taken ook door militairen uitgevoerd kunnen worden. In hoofdstuk 5 komt deze problematiok uitgebreid aan de orde.

7 Regeling intake het aanmerken van functies als organieke militaire of burgerfuncties, in: Maatschappelijke Raad voot de Krijgsmacht, advies mr. 16, Verhouding burger- en millitair personeel, Den Haag augustus $1989,6 \mathrm{zl}, 36$.

Iden, blz. 39 .
} 
Ook de functies onder c. kunnen door burgers worden vervuld, met dien verstande dat in de onder c. beschreven situaties de formele bevoegdheden van de burger een millitair karakter krijgen. Met andere woorden, voor deze functies is het niet nodig dat een militaire loopbaan doorlopen wordt, maar is het voldoende dat de burgers in het geval van buitengewone omstandigheden om kunnen gaan met de militaire gezagsverhoudingen. De taak van de burger zal veelal niet veranderen. De juridische verhoudingen echter wel.

Het onderscheid tussen functies met een geweldskarakter en een niet-geweldskarakter vinden we niet alleen in de krijgsmacht terug. Ook in onderzoeken naar de efficièntie en effectiviteit van de politie wordt in veel gevallen gekeken in welke mate een onderscheid kan worden gemaakt in "echt" politiewerk en functies waarin met een "beperkte" opsporingsbevoegdheid of helemaal geen opsporingsbevoegdheid kan wordlen volstaan. Zo stellen Boorsma en Bokkes in hun onderzoek naar de economische baten van hulpagenten dat:

"Het gegeven dat, ....., in verschillende mate gebruik wordt gemaakt van onvolledig-en niet-bevoegdien en men in werschillende mate mogelijkheden ziet om werkzaamheden over te laten nemen door nietvolledig-bevoegden geeft aan dat het mogelijk is dat men de mogelijkheden op dit punt onderschat"."

Het onderscheid tussen geweldsfuncties en niet-geweldsfuncties vinden we daarnasst terug bij de vredesoperaties van de Verenigde Naties. Met "peace-keeping" wordt getracht strijdende partijen te scheiden, zonder dat daarbij geweld wordt gebruikt. De wapens die de VN-troepen bij zich hebben dienen slechts ter zelfverdediging. Een functie in een "peace-keeping" eenheid is dus een functie waar in principe geen geweldselement aan gekoppeld is. Als er geweld wordt gebruikt is dit ter zelfverdediging. In het veld zien we dat naast militairen ook burgers in gezet worden om de vrede te handhaven. Eigenlijk zijn militairen helemaal niet nodig in VN-peace-keeping operaties. Dat er toch militairen ingezet worden in "peace-keeping" aktiviteiten komt omdat een alternatief veelal niet aanwezig is. Slechts de Zweden hebben een specifiek VN-departement. Dit VN-departement is een zelfstandig onderdeel van het Ministerie van Defensie. De mensen die worden uitgezonden in Zweeds VN-verband voor vredeshandhavingstaken worden geselecteerd uit een arbeidspool en gaan niet als militair aan het werk, maar als burgerambtenaar. ${ }^{10}$ Pas als een VN-opdracht verandert van "peace-keeping" in "peace-enforcing" is militaire deelname noodzakelijk daar het gebruik van geweld nu expliciet onderdeel uitmaakt van de opdracht en niet slechts dient ter zelfverdediging. 11

\footnotetext{
${ }_{9}$ P.B. Boorsma en W.T.M. Bokkes, De economische baten van hulpagenten, in: Openbare uitgaven 23, nu. 5, september 1991 .

10 Informatie verkregen door gesprekken met Zweedse ambtenaren, in casu de heser Kirsiten Lindholm, hoofd sectie oplleidingen, op het VN-departement in Stockholm, 19-8-1991. Deze informatie is terug te vinden in:

"Rapport vam het bezoek aan SCVR, Zweden door een delegatie van VVDM, Nederland, 15 t/m 19 augustus 1991 , hoofdstuk 5 en $6^{\prime \prime}$, S. Duindam, J. Leestemaker en R. Zaal. Commissie Internationale Zaken, Vereniging van Dienstplichtige Militairen, Utrecht.

11 In hoofdstuk 6 wordlt verder ingegaan op de VN-operaties en haar implicaties.
} 


\section{\$2,3. De organisatie van de krijgsmacht}

In paragraaf 1 van dit hoofdstuk hebben we gezien dat de krijgsmacht een organisatie van kapitaal en arbeid is, welke gevechtskracht produceert. Met deze gevechtskracht dient zij de vijand buiten de deur te houden, zowel ter land, ter zee, als in de lucht.

Voor dit alles is een adequate organisatie van de gevechtskracht nodig. In deze paragraaf zal een overzicht worden gegeven van de organisatorische opbouw van de krijgsmacht. Dit overzicht heeft tot doel te dienen als referentiekader voor de rest van dit proefschrift, waar gesproken wordt over de organisatie van de krijgsmacht of over onderdelen van de krijgsmacht.

De organisatieschema's zijn gebaseerd op de Defensienota 1991. De structuur van de Defensienota 1991 is tevens als uitgangspunt genomen voor de nadere analyses die in dit proefschrift woorkomen. Na de Defensienota 1991 is de Prioriteitennota uitgebracht. Daar de structuur van de Prioriteitennota vrijwel gelijk is aan die van de Defensienota 1991 zijn de analyses niet aangepast voor de Prioriteitennota. De systematiek is immers dezelfde gebleven, alleen de omvang van de veranderingen is in de Prioriteitennota nog iets toegenomen.

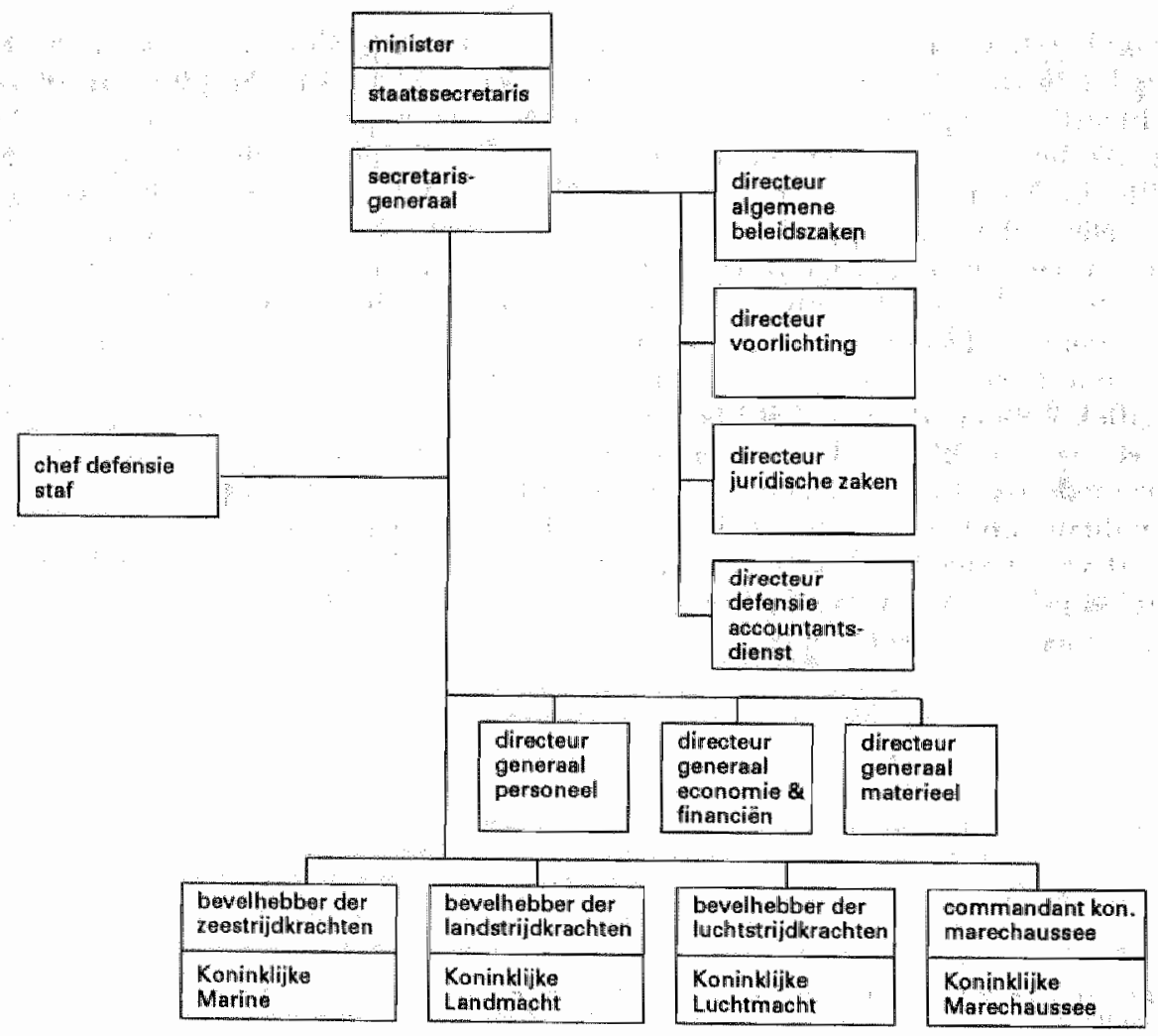

schema 2.1 De centrale organisatie 
De organisatie van de krijgsmacht kent aan de top de Centrale organisatie. Hoofdtaak van de Centrale organisatie is het sturen van de krijgsmachtdelen, Koninklijke Marine, Koninklijke Landmacht, Koninklijke Luchtmacht en Koninklijke Marechaussee, in termen van het beschikbaar stellen van middelen voor de gewenste produktie. De opbouw van de Centrale organisatie wordt weergegeven in schema 2.1 . De secretaris-generaal is de eerste ambtenaar op het Ministerie van Defensie. Hij is onder meer verantwoordelijk voor de informatievoorziening van de bewindsliedien en voor de integratie en de coördinatie van het beleid. De chef van de Defensiestaf is de hoogste adviseur op het gebied van het operationele beleid. Hij vervult een belangrijke rol bij de sturing van de krijgsmachtdelen. De directeuren-generaal zijn ieder op hun beurt belast met de ontwikkeling van en advisering over de hoofdlijnen van het beleid. Elk van de directeuren-generaal heeft een bijzondere taak. Deze is gekoppeld aan de instrumenten, die door de Centrale organisatie worden gehanteerd om de krijgsmachtdelen te sturen. Daarnaast kent de Centrale organisatie een aantal ondersteunende onderdelen, zoals de eenheid Gebouwen, Werken en Terreinen; de eenheid Automatisering, de eenheid Telecommunicatie en de eenheid Wetenschappelijk onderzoek.

Aan de top van de krijgsmachtdelen staat een bevelhebber of zoals bij de Koninklijke Marechausee een commandant. De bevelhebber van een krijgsmachtdeel is verantwoordelijk voor het beleid en de uitwoering van zijn krijgsmachtdeel. Ten behoeve van de overzichtelijkheid zal hier alleen de organisatie van de Koninklijke Landmacht worden witeengezet. De organisatie van de overige krijgsmachtdelen is qua structuur dezelfde, alleen de namen van de operationele delen verschillen. 12

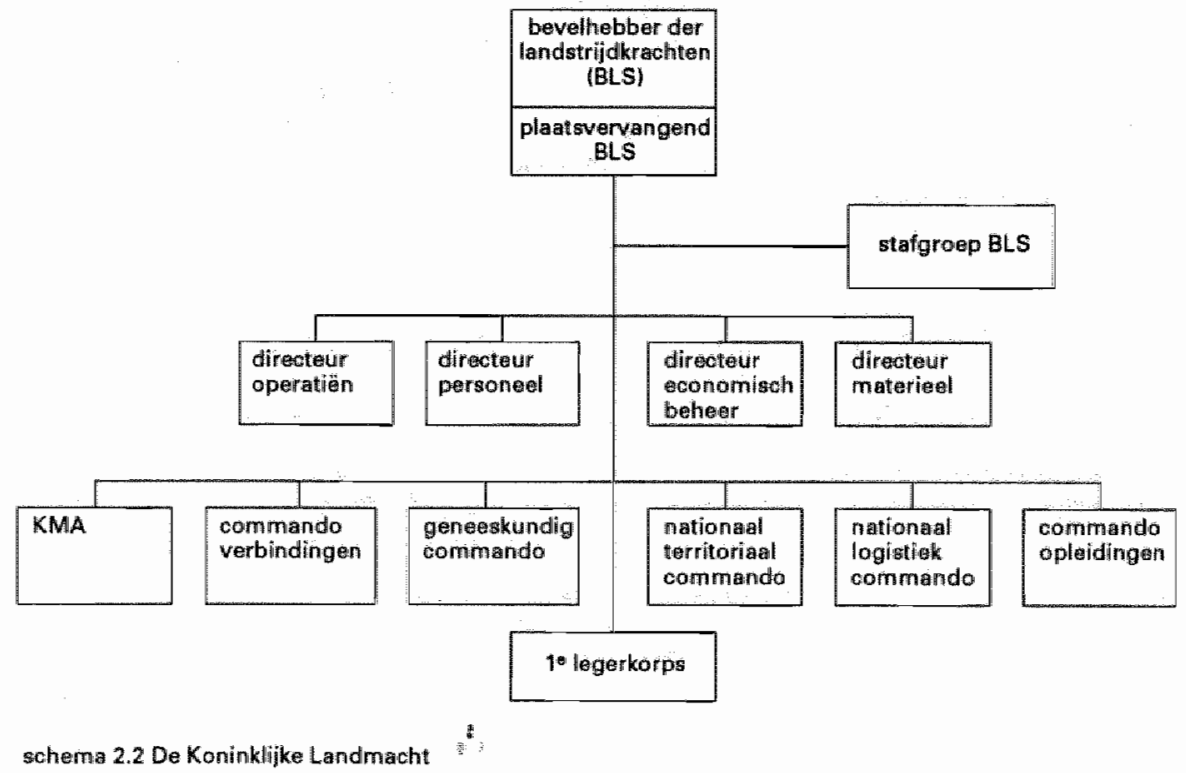

\footnotetext{
12De organisatieschema's vam de overige krijgsmachtdelen zujn terug to vinden in de Defensienota 1991, blk. 217230 en blz. $241-247$.
} 


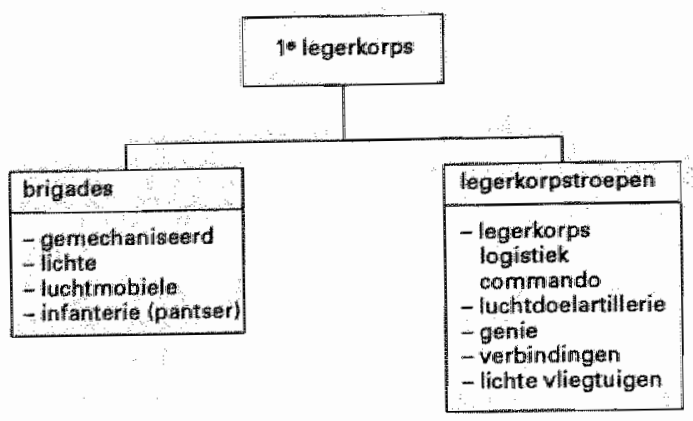

scherma 2.3 Het nogerkorps

Direct onder de bevelhebber der landstrijdkrachten staan de staven van de Koninklijke Landmacht. Deze zijn in schema 2.2. nader samengevat. Van alle onderdelen van de Koninklijke Landmacht is het le Legerkorps bedoeld om de vijand buiten de deur te houden. Ten einde een beter zicht te krijgen op de organisatie van dit 1e Legerkorps is in schema 2,3 . het 1e Legerkorps nader onderverdeeld in brigades en legerkorpstroepen. De brigades leveren de werkelijke gevechtskracht, maar zijn voor een goede uitvoering direct afhankelijk van de legerkorpstroepen.

Het le Legerkorps wormt in dit proefschrift het geheel van de gevechtseenheden van de Koninklijke Landmacht. Alle overige eenheden worden gezien als niet-gevechtseenheden. Enerzijds omdat deze eenheden geen directe gevechtskracht leveren, anderzijds omdat sommige van deze eenheden niet bedoeld zijn voor externe veiligheíd, maar een meer binnenlands karakter hebben.

De krijgsmacht is een organisatie van kapitaal en arbeid. Juist door de personeelscomponent in de krijgsmacht is de krijgsmacht een dynamische organisatie, die wordit gevormd door haat werknemers. Werknemers of in dit geval ambtenaren hebben ieder voor zich hun taak in de krijgsmacht. Naast hun taak hebben ambtenaren vaak ook hun persoonlijke doelstellingen. De volgende paragraaf gaat nader in op de mensen die deel uitmaken van de krijgsmacht, in het bijzonder de ambtenaren en de "ambtenaren"' in tijdelijke dienst, de dienstplichtigen.

\section{\$2.4. Defensie, dienstplicht en het gedrag van ambtenaren}

Defensie is, zoals eerder vastgesteld, een collectief goed. Dit betekent dat het proces van beslissen, gebruiken en betalen van éen goed niet in éen enkel persoon verenigd is. Vraag en aanbod worden niet door de markt samen gebracht. Bij collectieve goederen dient het budgetmechanisme het systeem van prijzen te vervangen. Het budgetmechanisme kan alleen efficiënt werken door de loyale medewerking van vele mensen, maar zoveel mensen er zijn, zoveel eigenaardigheden. In de collectieve sector en 
dus ook in de krijgsmacht speelt het gedrag van de producenten van collectieve goederen, de ambtenaren, een belangrijke rol. ${ }^{13}$

In vroegere literatuur speelde het gedrag van ambtenaren een ondergeschikte rol. Dit komt onder meer voort uit de organische gedachte over de staat. In een staat waar de organische gedachte prevaleert zijn individuen ondergeschikt aan de doeleinden van de staat en worden de persoonlijke voorkeuren van de ambtenaren als niet relevant beschouwd. Iedere organisatie, of het nu een particuliere of een ambtelijke betreft, wordt als een én en ondeelbaar organisch geheel beschouwd, waarvan de handelingen van haar onderdanen niet wezenlijk verschillen van die van het gedrag van de organisatie als geheel. Deze opvatting, ook wel de holistische organisatieopvatting genoemd, is niet goed bruikbaar om het gedrag van grote bureaucratische organisaties, zoals de krijgsmacht, te analyseren.

Hier staat een meer mechanische visie van de staat centraal. In deze visie is de rol van de staat ondergeschilkt aan die van het individu. Dat wil zeggen, verschillende individuen hebben de overheid opgericht ten einde tot een betere voorzlening van hun behoeften te komen. In deze mechanische visie is er ook plats voor analyses die het intern en extern functioneren van overheidsbureaucratieën beschrijven, zoals verricht door Downs en Niskanen. 14

Uit deze analyses blijkt dat het gedrag van ambtenaren een wezenlijk effect kan hebben op het bestaan van de dienstplicht. Het vertrekpunt in deze analyses is dat de ambtenaar niet langer wordt beschouwd als een "onpartijdig" organisatie-onderdeel, dat ondergeschikt is aan de doeleinden van de politieke leiding, maar als individu dat binnen de institutionele kaders van de organisatie maximalisatie van zijn eigen doelstellingen nastreeft.

In de studie van Downs wordt het interne functioneren van de leden van bureaucratische organisaties ontleed, of deze nu behoren tot de overheidssector of tot het bedrijfsleven. Bureaucratische organisaties, of kortweg bureaus, zijn organisaties die zich specialiseren in het aanbod van die voorzieningen, waarvan enige collectieve organisatie wenst dat de hoeveelheid toeneemt boven de hoeveelheid die door de markt geproduceerd wordt en waarbij die organisatie niet bereid is een contract af te sluiten met een winstzoekende organisatie. Bureaus hebben volgens Downs de volgende primaire karakteristieken ${ }^{15}$ :

1. Ze zijn groot.

2. De meeste medewerkers werken full-time, vrijwel hun gehele leven voor bureaus en krijgen het merendeel van hun inkomen uit deze bureaus.

3. Medewerkers worden aangenomen, blijven aan en promoveren voornamelijk op basis van een verwacht rolpatroon binnen een bureau.

4. Het overgrote deel van de produktie wordt direct of indirect niet geèvalueerd in externe markten, op basis van vrijwillige "quid pro quo" transacties.

De leden van het bureau, in ons geval ambtenaren op het ministerie van Defensie, worden in de opvatting van Downs gedreven door motieven van eigenbelang ten aanzien van de baten die aan hun positie verbonden zijn.

Niskanen heeft de externe verhouding tussen politici en ambtenaren geanalyseerd met behulp van een wiskundig-economisch model, waarin de politici publieke goede-

\footnotetext{
13 Voor het wolgende is ondermeer gebruik gemaakt van I.G.A. van Mietlo, Ambtelijk gedrag in bureaucratische organisaties, in A.F.A. Korsten en Th.A.J. Toonen, Bestuurskunde, Leiden, 1988, en N.A.A. Baakman (ed), Overheid en ondememing, een inleiding, Open Universiteit, Heerlen, 1991.

${ }^{14}$ Downs, A, Inside Bureaucracy, Boston, $1967 \mathrm{en} \mathrm{W.} \mathrm{Niskanen,} \mathrm{Bureaucracy} \mathrm{and} \mathrm{Representative} \mathrm{Government,}$ Chicago, 1971 .

1.5 Downs, bli. 24-31.
} 
ren en diensten vagen en daartoe aan ambtenaren produktieopdrachten verstrekken in ruil voor begrotingsgelden die hen ter beschikking worden gesteld. Dit model is een toepassing van een principaal-agent model. In een principaal-agent model worden twee (groepen) individuen onderscheiden.

De principaal, of opdrachtgever (in ons geval het parlement) geeft een opdracht aan het andere individu, de uitwoerder of agent en stelt daar een beloning tegenover. De principalal wordt verondersteld over minder informatie dan de agenten (uiltvoerende ambtenaren) te beschikken inzake de uitvoering van de opdracht. Vanwege deze situatie van asymmetrische informatie is het voor de principaal moeilijk na te gaan of het werk wel geschiedt volgens haar wensen. Zolang de uitkomsten niet al te sterk tegenvallen zal de agent haar of zijn gang mogen gaan. Daardoor krijgt hij of zij de ruimte om, binnen zekere grenzen, eigen doelstellingen na te streven.

Onder de vele variabelen die de doelstelling van een ambtenaar beïnvloeden zijn de volgende: salaris, status, macht, omvang van het bureau, het gemak waarmee hij of zij veranderingen bewerkstelligt en het gemak waarmee hij of zij een bureau kan leiden. Al deze variabelen behalve de latste twee zijn een monotoon stijgende functie van het totale budget van het bureau.

Niskanen maakt hieruit op dat ambtenaren zullen streven naar een zo groot mogelijk budget en dit zonder uitzondering. Zelfs ambtenaren met een voorkeur voor een lage beloning en een relatief grote motivatie om veranderingen ten gunste van het publiek te bewerkstelligen zullen streven naar budgetmaximalisatie. ${ }^{16}$ Budgetmaximalisatie is een noodzakelijke, maar niet voldoende voorwaarde in de bureaucratietheorie van Niskanen. Bureaus en ambtenaren worden in hun expansiedrift namelijk beperkt door de "output" die verwacht wordt door de principaal en waarvoor hil geld toebedeeld krijgt. Niskanen vat beide voorwaarden als volgt samen:

"Bureaucrats maximize the total budget of their bureau during their tenure, subject to the constraint that the budget must be equal to or greater than the minimum total cost of supplying the output expected by the bureau's sponsor."

Dit impliceert dat ambtenaren een prikkel hebben om de percepties van de sponsor te verleggen met behulp van promotionele activiteiten, analoog aan promotionele activiteiten in de marktsector. Ambtenaren van het Ministerie van Defensie kunnen dit ondermeer doen door extra nadruk te leggen op de veiligheidsrisico's in de wereld 18

Daar waar het bureau de grenzen van zijn budget bereikt, komt de dienstplicht in beeld. Dit komt omdat een bureau niet alleen te maken heeft met de principaal, maar met drie soorten groepen: 1) de collectieve organisatie die het bureau van geld voorwiet (de principaal), 2) de aanbieders van de produktiefactoren en 3) in sommige gevallen consumenten die voor bepaalde diensten een stukprijs betalen. Voor de krijgsmacht betekent dit concreet dat de sponsor het parlement is en onder de aanbieders van produktiefactoren de producenten van legermaterieel en de aanbieders van arbeid, waaronder de dienstplichtigen, moeten worden begrepen.

De relatie van de ambtenaren van het Ministerie van Defensie met hun principaal, het parlement, is hervoor reeds uitgelegd. Het parlement stemt iedier jaar bij de be-

\footnotetext{
16 Niskanen, blz. 38 .

17 Jdem.

18 Na het uitkomen van het rapport van de Commissie Mejer ontstond in de media een felle discussie over de analyse van de intemationale velligheidssituatie. Voorstanders van de dienstplicht wezen in deze ciscussie op het chaoktische karakter van de internationale veiligheidssituatie en de dreiging die daaruit zou voortwloeien. De voorstanders van deze zienswijze op de internationale veiligheidssituatie waren voomamelijk te vinden onder die defensieambtentaren die de oprerationele taken moesten uitvoeren.
} 
grotingsbehandeling over de defensiebegroting en na zijn goedkeuring beschikt de krijgsmacht over de financiën om haar produkt te bewerkstelligen. Er zal worden uitgegaan van een passief parlement, dat kennis heeft van het budget dat hij bereid is te geven voor een bepaalde gevechtskracht, maar dat niet de middelen of mogelijkheden heeft de informatie te achterhalen wat minimaal noodzakelijk is om deze gevechtskracht voort te brengen. 19

De tweede relatie, die tussen krijgsmacht en de aanbieders van produktiefactoren, is in deze studie naar de dienstplicht van groot belang. De meeste bureaus betrekken hun arbeid en kapitaal op concurrerende markten. Zij betalen dezelfde prijs voor gelijke soorten produktiefactoren. Onder deze voorwaarden zal er weinig verschil zijn tussen bureaus en winstgerichte ondernemingen met betrekking tot het aantrekken van kapitaal en arbeid.

De eerste basis voor loon- en factorprijsdiscriminatie, waarvan dienstplicht eén. vorm is, is dat bureaus vaak de enige aanbieder van bepalalde diensten zijn. Deze bureaus hebben een monopolie als vrager van de arbeidsvaardigheden en kapitaal, die nodig zijn voor de produktie van de onderhavige diensten. Een tweedle basis voor loon-en factorprijsdiscriminatie is dat zulke bureaus vaak een eerste claim willen leggen op bronnen, waarvan het bezit veelal gemeenschappelijk lijkt te zijn.

Deze bronnen omvatten onder meer zaken als de licht, nucleair materiaal, grond, maar ook gezonde intelligente jonge mensen. De mogelijkheden voor monopsonistische discriminatie zullen door bureaus benut willen worden, omdat dit zowel het budget als de "output" van het bureau vergroot. Het uitoefenen van loon- en factorprijsdiscriminatie is hoofdzakelijk gelimiteerd tot nationale bureaus ${ }^{20}$, omdat deze een grotere monopoliemacht hebben, gebruik maken van ingewikkeld materiaal en beschikken over gemeenschappelijke bronnen. Toch moet dit niet als een algemene karakteristiek van bureaus worden beschouwd.

Loon-en factorprijsdiscriminatie is een riskante zaak indien de belangen van de personen, die arbeid en kapitaal aanbieden, sterk vertegenwoordigd zijn in het parlement. In zo'n geval zal een bureau zijn mogelijkheden niet ten volle willen benutten, omdat het anders de steun van zijn sponsor snel zal verliezen. Maar als de bezitters van kapitaal en arbeid niet sterk vertegenwoordigd zijn in de sponsororganisatie, zoals geldt voor de voor dienstplicht geschikte jongemannen, zullen bureaus voortdurend neigen hun mogelijkheden tot loon- en prijsdiscriminatie uit te breiden. Vaak wordt zo'n beroep gerechtvaardigd door te wijzen op de rechten van de staat of de burgerplicht.

De analyse van bureaus, die loon-en factorprijsdiscriminatie gebruiken, leidt tot de volgende door Niskanen gegeven gedragshypothese:

"Some bureaus, specifically those that operate in the budget-contrained reglon ${ }^{21}$ and face increasing prices for specific factors, may exercise factorprice discrimination. They have a larger budget and output of services (and a lower average budget per unit of output) than other bureaus with similar demand and cost conditions that pay competitive prices. Such factorprice discrimination is most likely to

it

\footnotetext{
19 De werkelijkheid is helaas niet anders. Debatten op defensiegebied komen sporadisch voor ten zeker op budgettair terrein toont het parlement de laatste jaren geen pogingen meer het onderste wit de kan te willen halen. Dit heieft $\infty \mathrm{k}$ te maken met het feit dat de informatievoorziening ulit het Ministerte van Defensie zeer moeizaam is. Dit gell dt ook voor informatie naar de kamerleden. De Walrus affaire is een voorbeeld van een disdelijke discussle over de efficièntie en doelmatigheid in de krijgsmacht, maar toen was hett kalf al verdronken.

20 De roep om dienstplicht is maar al te vaak te horen ult kringen van producenten uilt de collectieve sector: polite. gezondheidsworg, bejaardemzorg, onderwijs etc.

21 Uitleg van dit begrip volgt verderop in deze paragraaf.
} 
be used on those specific factors which are weakly represented by the officers of the sponsor organizathon."22

Niskanen maakt in zijn verhalal een onderscheid tussen een bureau dat opereert in een "budget-constrained-region" en een bureau dat opereert in een "demand-constrainedregion". Met betrekking tot de consequenties voor de dienstplicht is het goed even stil te staan bij het onderscheid tussen bureaus die in een "budget-constrained-region" werken en de bureaus die werken in een "demand-constrained region".

In het eerste geval hebben we te maken met een normalle principaal-agent verhouding, waarbij het budget van het bureau door de principaal wordt vastgelegd. Indien de principaal volledig inzicht in het bureau heeft, is budgetmaximalisatie volledig consistent met kostenminimalisatie op het evenwichtsniveau van de produktie. In $z 0^{\prime \prime} \mathrm{n}$ geval is loon-en factorprijsdiscriminatie, of in ons geval dienstplicht, vrij moeilijk te realiseren. Dit komt omdat de sponsor de kosten van de dienstplicht in zijn besluitvormingsproces zal betrekken. Dit betekent echter niet dat dienstplicht in dit geval uitgesloten is, maar dat dienstplicht in zo'n situatie niet waarschijnlijk is.

In het geval dat een bureau in de "demand-constrained-region" werkt, spelen externe omstandigheden een grote rol bij de bepaling van het budget. Het bureau ontsnapt aan het strikte toezicht van de principaal, omdat het bureau er voor moet zorgen dat de voorziening in alle omstandigheden aanwezig is. Voor de krijgsmacht betekent dit dat zij de vijand dient te weerstaan. Daarbij maakt het niet uit hoe.

Hier komt dan ook de gedachte uit voort dat economisch handelen niet echt mogelijk is binnen de krijgsmacht, omdat deze een specifieke opdracht heeft. In zon situatie kan dienstplicht gemakkelijker gedijen, omdat de kosten van dienstplicht geen rol spelen. Indien een bureau zich in een "demand-constrained-region" ten aamzien van zijn "output" bevindt, zal het bureau zich niet meer interesseren voor mogelijke kostenbesparingen en zal het tevens ongevoelig zijn voor kostenstijgingen die de "output" van het bureau verlagen zonder dat de "demand-constrained-region" verlaten wordt. Indien door de sponsor gevraagd wordt de kosten te verminderen, zal een bureau dat diverse diensten verzorgt, proberen de kosten te verminderen op "budgetconstrained" diensten, terwijl op dle "demand-constrained" diensten de kosten zo hoog opgevoerd worden dat het hele budget hierdoor uitgeput raakt en kostenvermindering onmogelijk lijkt.

In de tijden van de Koude Oorlog kon gesteld worden dat de krijgsmacht zich in de "demand-constraint-region" bevond. Een situatie waarin het kostenbesef niet echt duidelijk aanwezig hoefde te zijn. Met het einde van deze "'oorlog" dreigt de krijgsmacht in haar geheel terug te vallen naar de "budget-constrained region" met alle gevolgen van dien.

De kosten van de krijgsmacht zullen weer belangrijk worden en het parlement zal zijn rol als ouderwetse principaal moeten spelen door duidelijk aan te geven welke "output" de krijgsmacht produceren moet. De ambtenaar binnen de krijgsmacht zal belemmerd worden in zijn streven naar macht en status en zal wellicht in zijn geheel een stapje terug moeten doen.

In de volgende hoofdstukken spelen de in deze paragraaf beschreven aspecten een belangrijke rol. Zo worden in hoofdstuk 4 en 5 de kostenaspecten nauwgezet geanalyseerd en bekijkt hoofdstuk 8 de problemen en conflicten die zich voor doen in het conversietraject van een dienstplichtigenleger naar een vrijwilligersleger.

22 Niskanen, ble, 50 . 
Samenvattend kunnen we stellen dat de in deze paragraaf beschreven principaalagent theorie en het daarmee samenhangende gedrag van ambtenaren in verband kan worden gebracht met het instituut militaire dienstplicht. Een verband dat zonder meer duidelijk wordt, indien aan de krijgsmacht gevraagd wordt in te krimpen, daar in zo'n situatie het budget van de krijgsmacht niet meer wordt bepaald door de vijand, maar door het publieke besluitvormingsproces. Een kostenminimaliserende krijgsmacht zal zonder meer botsen met de budgetmaximaliserende ambtenaren, die werkzaam zijn in diezelfde krijgsmacht. Toch is het niet zo dat dienstplicht uitsluitend samenhangt met het gedrag van ambtenaren, ook het publieke besluitvormingsproces heeft haar effect op het collectieve goed defensie en de dienstplicht.

$\S 2.5$. Dienstplicht, vrijwillige dienst en de rol van het publieke besluitvormingsproces bij de grootte van het collectieve goed defensie

In de vorige paragraaf hebben we kunnen zien dat dienstplicht niet een vanzelfsprekend verschijnsel is. Bureau's proberen in hun streven naar budgetmaximalisatie factorprijsdiscriminatie toe te passen, waarvan dienstplicht een exponent is. Zoals we reeds in hoofdstuk 1 zagen is dienstplicht een belasting-in-natura. Indien we beseffen dat fiscale keuzes niet slechts vaststaande data, maar het gevolg van een publiek besluitvormingsproces zijn, dan kunnen we de keuze tussen dienstplicht en vrijwillige dienst ook met ons economische gereedschap analyseren.

Deze paragraaf heeft als doel de dienstplicht te onderzoeken vanuit een alternatief referentiekader. ${ }^{23} \mathrm{Het}$ standaardkader gaat uit van een marktgeoriènteerde, ${ }^{\text {per- }}$ soonlijke keuze; de grootte en samenstelling van het budget voor het collectieve goed defensie worden als gegeven verondersteld en vervolgens worden de effecten van alternatieven in de belastingheffing (dienstplicht of vrijwilligersleger) op de verdeling van inkomen en de allocatie van produktiefactoren onderzocht. ${ }^{24}$

\section{\$2.5.1. Het model}

We veronderstellen dat we leven in een "twee-goederen-wereld" van "boter" en "kanonnen", waarbij boter een surrogaat is voor alle burgerlijke, niet militaire diensten en kanonnen een surrogaat zijn voor alle militaire diensten. In deze twee-goederen-wereld zijn n-individuen aanwezig, die bij meerderheid beslissen hoeveel boter en hoeveel kanonnen er aangeboden zullen worden. ${ }^{25}$

We beginnen met de beschrijving van het budgettaire evenwicht dat resulteert indien de inputfactoren kapitaal en arbeid bij het produktieproces van de kanonnen door middel van vrijwilligheid ter beschikking worden gesteld. Daarna zal in $\$ 2.5 .2$. de

\footnotetext{
23Deze arualyse is gebaseerd op het werk van Richard E. Wagner, Conscription, Voluntary Service, and Democratic Fiscal Choice: in Buchanan and Tollison, Theory of Public Choice, 1972, biz.136-152.

${ }^{24}$ De initiale keuze tussen wel of geen dienstplicht en het voortbestatan van de dienstplicht komt in hoofdstuk 3 , paragraaf 5 aan de orde. Hier wordt voomamelijk gekeken naar de grootte van thet collectieve goed defensie als gevolg van de keuze wel of geen dienstplicht.

25 Het gebruikte model lijkt op het Samuelson-model inzake de bepaling van de grootte van collectieve groederen, doch is het zeer zeker niet. In dit proefschrift en in deze paragraaf wordt de grootte wan het collectieve goed in hoofdzaak bepaald door de internationale veiligheidssituatie en in tweede plaats door het prolitioko beslu:tvormingsproces en dat laatste als gevolg van alternatieve fiscale keuzen. In dit model gaat hot dus om de grootto van het collectieve goed als gevolg van de ketuze tussen wel of geen dienstplicht, zoals in voetnoot 23 is gesteld, ten niet om de grootte van, het collectieve goed defensie als gevolg van de keuze tussen uitgaven voor defensie of uitgaven voor ander beleidsterrein.
} 
dienstplicht worden geintroduceerd en wordt nagegaan wat het effect van de dienstplicht is op het budget dat besteed wordt aan kanonnen.

leder individu $(i)$ heeft een nutsfunctie $U_{i}=F_{i}(B, K)$ waarbij $B$ de hoeveelheid boter aangeeft die voor leder individu beschikbaar is en $K$ de hoeveelheid kanonnen dat beschikbaar is voor de gemeenschap waarvan individu (i) deel uit maakt. Ieder individu (i) maximaliseert zijn nut onder de budgetrestrictie $P_{b} B+P_{k} K=I_{i}$, waarbij $I_{i}$ het inkomen is van individu $(i)$ en $P_{b}$ en $P_{k}$ de prijzen zijn van respectievelijk boter en kanonnen.

Voor ieder individu ( $i)$ geldt dat $T_{i}=T_{i}(K)$ de hoeveelheid belasting weergeeft die betald moet worden voor de hoeveelheid aangeboden kanonnen. Met deze belasting wordt tevens aangegeven hoeveel boter individu (i) bereid is op te geven voor de kanonnen.

$V_{i}=V_{i}(K)$ geeft aan welke waarde de aangeboden hoeveellheid kanonnen heeft voor individu(i). Zolang $V_{i}^{\prime \prime}(K)>T_{i}^{\prime}(K)$ heeft het individu (i) een woorkeur woor de uitbreiding van het aantal kanonnen, omdat zijn marginaal nut van de kanonnen het marginal nut van boter dat hij op moet offeren overtreft.

De optimale hoeveelheid kanonnen, het budget voor militaire diensten voor een individu $(i)$, is die hoeveelheid waarvoor geldt $V_{i}^{\prime}(K)=T_{i}(K), 26$ Indien we de voorkeur van én individu in de gemeenschap vertalen naar de resultaten voor de gehele gemeenschap krijgen we dle volgende vectoren:

$T=\left(T_{1}^{\prime}(K), T_{2}(K), \ldots \ldots, T_{19}(K)\right)$ is een vector van marginale belastingprijzen, waarbij $T>0$ en $V=\left(V_{1}^{\prime}(K), V_{2}(K), \ldots ., V_{n}^{\prime}(K)\right)$ is een vector die de waarde van marginale uitgaven aan kanornen weergeeft, waarbij $V>0$. Uit deze vectoren is een derde vector af te leiden voor de netto marginale voorkeur $P$, zodat $P=-T+V$. Bij het kiezen voor een kleine marginale toename van het aantal kanonnen, zal een individu hiermee instemmen zolang $P_{i}>0$. Een gemeenschappelijke beslissing om de hoeveelheid kanonnen te vergroten zal werkelijkheid zijn zolang $P_{i}>0$ voor $m>(n+1) / 2$ individuen, waarbij $n$ een oneven getal is.

Er zal evenwicht in het gemeenschappelijk aanbod wan kanonnen zijn indien:

$-P_{l}>0$ voor $(n-1) / 2$ individuen $i=1,2, \ldots, j-1$;

$-P_{i}=0$ voor 1 individu $i=j$; en

$-P_{i}<0$ voot $(n-1) / 2$ individuen $i=j+1, j+2, \ldots ., n$.

De eerste groep heeft boven mediane voorkeuren, de laatste groep heeft voorkeur beneden het niveau van de mediane kiezer en individu $(j)$ is de mediane kiezer. In dit mediane kiezersmodel zal een aantal kanonnen $K_{0}$ worden gekozen. Individuele belastingbetalingen zullen gelijk zijn aan $t=K_{0} T_{i}(K)$ en de totale belastingbetalingen $R$ zullen $R=K_{0} T \mu$ bedragen. 27 Grafisch laat zich dit weergeven zoals is gedaan in figuur 2.1 .

\footnotetext{
26 Hierbij wordt verondersteld dat wordt voldaan aan de tweede-orde voorwaarden: $V_{i}^{\prime \prime \prime}(K)<0$ en $T_{i}^{\prime \prime}(K)>0$.

$27 \mu$ is een vector die noodzakelijk is $R$ om uit te drukken in éen enkel getal.
} 


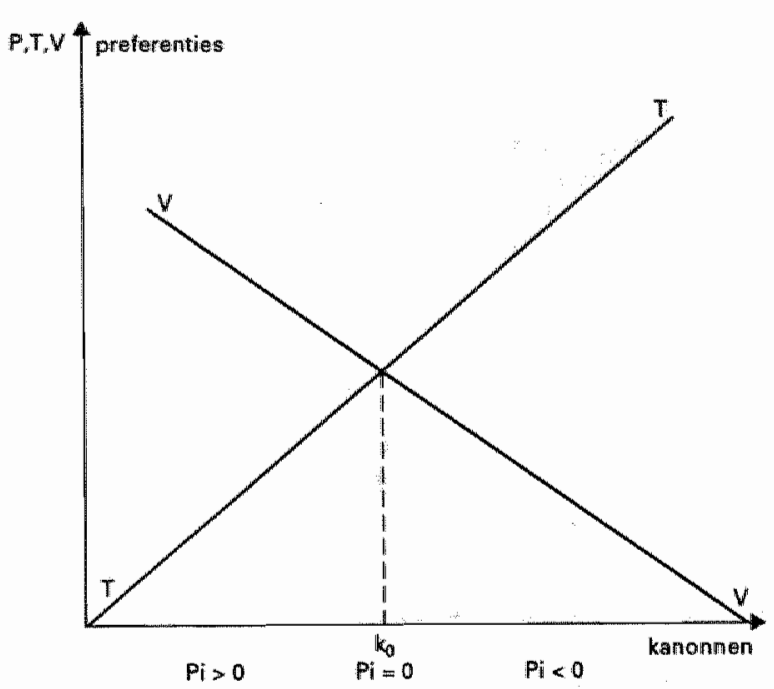

figuur 2.1 Het mediane lkiezersmodel en de voorkeur voor boter en kanornen

\section{\$2.5.2. De invoering van de dienstplicht}

Dienstplicht is een belasting-in-natura. Indien we de dienstplicht toevoegen aan de bestaande monetaire belastingen, dan vinden we dat dienstplichtigen een hogere prijs voor kanonnen betalen dan niet-dienstplichtigen met een gelijk inkomen. Het opleggen van de dienstplicht is dan ook op te vatten als een inkomenstransfer van dienstplichtigen naar niet-dienstplichtigen.

$\lambda=\left(\lambda_{1}, \lambda_{2}, \ldots, \lambda_{n}\right)$ is een vector multiplicatoren die er voor zorgt dat $K_{0} T \mu=K_{0} T \lambda .{ }^{28}$ Dienstplicht verandert de structuur van de belastingen op zo'n manier dat $\lambda_{1}>$ lvoor dienstplichtigen en $0<\lambda_{1}<1$ voor niet dienstplichtigen. De "per-unit" belastingprijs wordt $T_{i}^{\prime}(K) \lambda_{i}$, en de individuele belastingbetaling wordt $K_{0} T_{i}^{\prime}(K) \lambda_{i}$.

Door de werking van het publieke besluitwormingsproces met betrekking tot de keuze van belastinginstrumenten, zal de verandering in de structuur van de belastingprijzen doorwerken in de hoeveelheid kanonnen die zal worden verkozen door de gemeenschap.

We zullen onderzoeken hoe de verandering in het belastingstelsel doorwerkt op de budgettaire politiek, zowel in het geval dat dienstplichtigen uitgesloten worden van het kiezersbestand van de gemeenschap als in het geval dat de dienstplichtigen wel degellik deel uit maken van het kiezersbestand.

Indien dienstplichtigen uitgesloten worden van het kiezersbestand zullen hun preferenties de gemeenschappelijk keuze niet beïnloeden, behalve in het geval dat er mensen zijn in het overige kiezersbestand die persoonlijk meer geïnteresseerd zijn in de belangen van specifieke dienstplichtigen dan in hun eigen belangen. Omdat $T_{i}^{\prime \prime}(K) \lambda_{i}<T_{i}^{\prime}(K)$ voor niet-dienstplichtigen, zullen de individuen die reeds een $P_{i}>0$ hadden onder vrijwillige dienst dit nu ook hebben.

Voor de mediane kiezer zal in het geval van dienstplicht nu ook gelden dat $P_{i}>0$. En van de $(n-1) / 2$ individuen die eerst een $P_{i}<0$ hadden, zullen enige individuen

$28 \mu$ is een belasting in geld, terwijl $\lambda$ een belasting in natura is met dezelfde waarde alls $\mu$. 
nu een $P_{i}>0$ ondervinden.29 Uitbreiding van het aantal kanonnen is het resultaat, omdat $P_{i}>0$ voor $m>(n+1) / 2$ individuen in het kiezersbestand. Deze uitbreiding zal voortduren tot dat een nieuw evenwicht, $K_{1}$, is bereikt. Dit nieuwe evenwicht voldoet aan de hiervoor beschreven woorwaarde voor evenwicht onder meerderheidsbeslissingen.

Indien dienstplichtigen wel stemrecht hebben, zal de anallyse veranderen en hierbij onderscheiden we twee uitersten. In het eerste geval veronderstellen we dat alle dienstplichtigen thuis horen in de groep voor wie $P_{i}<0$ onder vrijwillige dienst geldt. Zelfs indien deze groep geheel uit dienstplichtigen bestaat (dat wil zeggen $(n-1) / 2$ deel van de bevolking is dienstplichtig) houdt de hiervoor beschreven analyse zonder uitzondering stand, waarbij $P_{j}=0$. Indien er minder dan $(n-1) / 2$ dienstplichtigen zijn, zullen sommige individuen die eerst $P_{i}<0$ ervoeren door de verandering in de belastingprijzen nu $P_{i}>0$ ervaren en een additionele toename van kanonnen is het resultaat.

Het bezitten van stemrecht van dienstplichtigen kan dus alleen de uitkomst van het publieke besluitvormingsproces beinvloeden in het tweede geval, waarbij sommige dienstplichtigen toebehoren tot de groep waarvoor onder vrijwillige dienst $P_{i}>0$ gold. Net als in het eerste geval kunnen we veronderstellen dat alle dienstplichtigen voordat dienstplicht wordt ingevoerd tot de groep $P_{i}>0$ behoren.

Dienstplicht betekent dat voor sommigen $P_{i}<0$ wordt en is het de vraag waar de nieuwe everwichtswaarde van $K_{\sharp}$ zal uitkomen. De nieuwe evenwichtswaarde zal afhangen van de herschikking van de voorkeuren van zowel dienstplichtigen als mietdienstplichtigen.

Indien de hoeveelheid kanonnen stijgt naar $K_{1}$, stijgt het budget voor kanonnen met $\left(K_{1}-K_{0}\right) T \lambda$, witgedrukt in termen van opgeofferde boter. Voor de minderheidsfractie, de dienstplichtigen, geldt dat $K_{1} T_{i}^{\prime}(K) \lambda_{i}>K_{0} T_{i}^{\prime \prime}(K)$ omdat $K_{1}>K_{0}$ en $\lambda_{i}>\mathbb{1}$. Voor de meerderheid in de gemeenschap, de niet-dienstplichtigen, geldt echter $K_{1} T_{i}(K) \lambda_{i}>=<K_{0} T_{i}^{\prime}(K)$ omdat $K_{1}>K_{0}$ tegengesteld is an $\lambda_{1}<1$. Bij enige inelasticiteit in de vraag naar kanonnen zullen de totale betalingen door niet-dienstplichtigen verminderd worden, doch met minder dan de toename van de last voor de dienstplichtigen. In een situatie van dienstplicht zijn de marginale kosten voor de meerderheidsfractie van de kiezers, die in per capita termen luiden:

$\left(\sum_{i=1}^{\infty} T_{i}^{\prime \prime}(K) \lambda_{i}\right) / j$

lager dan de kosten voor de gehele gemeenschap, die per capita luiden:

$\left(\sum_{i=1}^{1} T_{i}(K) \lambda_{i}\right) / n+\left(\sum_{i=j+1}^{n} T_{i}^{\prime}(K) \lambda_{i}\right) / n$

Omdat de keuze van de gemeenschap gebaseerd zal zijn op de marginale kosten van de meerderheidscoalitie, die minder zijn dan de marginale sociale kosten van de gehele gemeenschap, leidt belastingdiscriminatie tot de standaardkritiek van Pigou over het verschil tussen marginale private kosten en marginale sociale kosten en een grotere hoeveelheid kanonnen.

\footnotetext{
29 Voor analytikch gemak is verondersheld dat de bevolking een normale continue verdleling kent ten opzichte van
hutu woorkeuren woor boter en karonnen.
} 
In deze paragraaf hebben we gezien dat het waarschijnlijk is dat een dienstplichtigenleger een grotere hoeveelheid "output" (kanonnen) produceert dan een vrijwilligersleger. De uitbreiding van de hoeveelheid kanonnen is hier niet het gevolg van de drang tot budgetmaximalisatie van bureaucraten, maar de uitkomst van een democratisch besluitvormingsproces, waarbij een meerderheid van de gemeenschap een minderheid de last van de bescherming van het land oplegt.

\section{\$2.6. Samenvatting}

Dit hoofdstuk heeft een verscheidenheid aan analyses laten zien die allen toepasbatar zijn op het collectieve goed defensie en de producent van dit goed: de krijgsmacht. Concluderend kan worden gesteld dat economische theorieen hun geldingskracht binnen de krijgsmacht niet verliezen, maar er zelfs voor zorgen dat interessante verschijnselen naar voren komen. Tevens heeft dit hoofdstuk ons een kijkje gegeven in de keuken van het economisch gereedschap waarmee de militaire dienstplicht nader onderzocht kan worden. Naast het gereedschap dat de algemene economie en de economische theorie van de politieke besluitvorming (public choice) ons biedt, zal ook als gereedschap de literatururstudie worden gebruikt. Van het gereedschap is vooral de combinatie van neo-klassieke economie en public choice belangrijk, omdat met deze instrumenten de analyse van de dienstplicht een meerzijdig gezicht kan worden gegeven. In een analyse van de personeelscomponent in de krijgsmacht is niet alleen een beschrijvende of fundamentele analyse van de factor arbeid van belang, een misschien nog wel belangrijker deel van de analyse is ingeruimd voor de economische gevolgen van het gedrag van mensen in de krijgsmacht als gevolg van de militaire dienstplïcht. Zowel het gedrag van individuen, groepen mensen, als afdelingen of zelfs gehele krijgsmachtdelen staat hier centraal. Een meer toegepaste uitwerking van de theorieën met behulp van de hier getoonde methoden en technieken zal in de komende hoofdstukken plaatsvinden. 



\title{
De geschiedenis en het voortbestaan van de dienstplicht in Nederland
}

\begin{abstract}
"Een plant van vreemde bodem, die hier nimmer had willen aarden, verderfelijk voortbrengsel van de Franse revolutie, symptoom ook van neergang in beschaving". Tweede Kamerlid van reactionair-conservatieve zijde in de 19 e eeuw, in: F.C. Spits, Klassedienstplicht in de negentiende eeuw, plaatsvervanging en afkoop: Driekwart eeuw historisch leven in Den Haag, 1975.
\end{abstract}

Het verdedigen van zijn bezit houdt de mens al eeuwen bezig. Soms is de vijand het water en bouwen we terpen en dijken. Een andere keer staan de mensen tegen elkaar op en moet de mens zijn bezit man tegen man verdedigen. In de duizendjarige periode, die aan de invoering van de algemene en persoonlijke dienstplicht in ons land is vooraf gegaan, is het geheel van de krijgsdienst tot aan de middeleeuwen vooral een standsprivilege geweest, vervolgens tot de ondergang van de Republiek een beroep en daama een verplichting, die aan eén klasse toegewezen werd en dan met name aan de onderste klassen in de samenleving. In tegenstelling tot vroeger tijden is het in de laatste periode een voorrecht van de verplichting tot militaire dienst ontheven te zijn. 1

In dit hoofdstuk zal het ontstaan en het voortbestaan van de dienstplicht onder de loep worden genomen. In het eerste gedeelte van dit hoofdstuk staat dle geschiedkundige ontwikkeling van de dienstplicht centraal. In dit deel is een afzonderlijke plaats ingeruimd voor het verschijnsel plaatsvervanging. In het tweede deel van het hoofdstuk wordt de nadruk gelegd op de theoretische aspecten van het voortbestaan van de diensitplicht in een democratische omgeving.

\section{\$3.1. Het ontstaan van de militaire dienstplicht ${ }^{2}$}

In de loop der eeuwen heeft de militaire dienstplicht tijden wan bloei en tijden van neergang gekend. In de middeleeuwen werd weinig van de militaire dienstplicht vernomen, maar de geest van de militaire dienstplicht komt onder invloed van de Renaissance terug uit de fles, waar zij sinds de Romeinse tijd in verstopt was. De primitieve structuur van de staat in de żestiende eeuw was echter zodanig dat de prakti-

\footnotetext{
1Zie ook F.C. Spits: Klassedlienstplicht in de negentiande euw, plaatsvervanging en afkoop, in: Driekwart teeuw historisch leven in Dan Haag, 1975, blz 201.

2 Deze pariagraaf is ondermeer gebaseerd op: C.T. Campagne, Over het ontstaan en de ontwikkeling wan het instituut van de millitaire dienstplicht, in: Kernw raag 4, blz. 5-24, 1968 .
} 
sche uitvoering van de in artikel 7 van de Unie van Utrecht opgenomen dienstplicht onmogelijk was.

Hoewel er enige formele pogingen zijn geweest, hebben het ontbreken van een krachtig organiserend vermogen en de afwezigheid van nationaliteitsgevoel de meeste verordeningen op het gebied van de militaire dienstplicht tot een dode letter gemaakt.

De gedachte van de militaire dienstplicht komt aan het einde van de achttiende eeuw krachtig tot leven met de Franse Revolutie. De "levée en masse", waardoor alle mannelijke Fransen van 18 tot 40 jaar ter beschikking van Parijs werden gesteld, verschafte Frankrijk in 1793 een leger van 650.000 man. Door de gang van zaken in Frankrijk werd in Nederland in 1798 de persoonlijke dienstplicht formeel ingevoerd.

De uitvoering van de dienstplicht laat evenwel tot zich wachten tot $1810 \mathrm{en}$ komt pas echt tot stand met de inlijving van Nederland bij Frankrijk. Ieder jaar wordt door loting een deel van de Nederlandse jongeren aan de legers van de Franse keizer toegevoegd.

Na de ineenstorting van het Napoleontische Rijk in 1813, staat Nederland onder de invloed van de soevereine vorst der Nederlanden. Eén van diens taken is de organisatie van een nieuwe krijgsmacht. Nadat hij eerst vrijwilligers oproept, komt hij later tot de oprichting van een landstorm en een landmilitie, waarbij de landmilitie zou worden gevormd uit personen van tussen 17 en 46 jaar. Loting zou beslissen wie dienen moest, waarbij plaatsvervanging was toegestaan. ${ }^{3}$ Zo ontstond langzamerhand naast een uit vrijwilligers gevormd staand leger een dienstplichtigenleger, gebaseerd op dezelfde dienstplicht die kort te voren onder Napoleon zo gehaat was geweest.

In 1814 wordt een algemene, persoonlijke dienstplicht in de grondwet ingevoerd, en als uitvloeisel hiervan komt in 1815 de eerste militiewet tot stand. De praktijk leerde dat de werving voor het staande leger slecht vlotte, omdat wie zich als vrijwilliger willde verbinden aan de krijgsmacht dit voordeliger als plaatsvervanger kon doen. Bij koninklijk besluit werd vervolgens besloten de nationale militie samen te voegen met de vrijwilligers. Het begin van de opheffing van het staande leger was daar en de krijgsmacht ontwikkelde zich in de richting van een dienstplichtigenleger. "Bij gebrek aan vrijwilligers had het Napoleontische conscriptiestelsel gezegevierd", aldus Campagne. ${ }^{4}$

\section{\$3.2. Plaatsvervanging 5}

Eén van de belangrijkste oorzaken van de mislukking van een staand of vrijwilligersleger is te vinden in het systeem van plaatsvervanging of nummerverwisseling in het dienstplichtsysteem van de negentiende eeuw. In de loop van de negentiende eeuw is de dienstplichtgedachte vrij algemeen aanvaard. Iedereen had de verplichting bij te dragen in de verdediging van het land. Echter kwantitatief was deze verplichting beperkt. Voor een bedrag dat bepaald werd door vraag en aanbod kon de rijkere man zich laten vervangen door iemand anders.

Op principiële gronden werd de plaatsvervanging nauwelijks bestreden. Plaatsvervanging was een systeem dat toentertijd voor heel Europa gold. Plaatsver-

\footnotetext{
3 Zi patagraat 2 voor en witgobreide werhandeling over het verschijnsel plaatswervanging.

${ }^{4} \mathrm{C}$. $\mathrm{T}$. Campagne, op cit., blz 7 .

5 Deze paragraaf is gebaseerd op het werk van F.C. Spits: Klassedienstplicht in de negentiendle eeuw; plaatsvervanging en afkoop, in: Driekwart eeuw historisch leven in Den Haag, 1975, blz. 187-201.
} 
vanging was bovendien moreel verantwoord, omdat als het gevaar echt aanwezig was de ongelijkheid tussen rijken en armen zou vervallen, omdat de rijken zich dan ook beschikbaar zouden stellen ter verdediging van het grondgebied. In de negentiende eeuw strekte de periode van mobilisatie en concentratie zich namelijk over vele maanden uit voordat een oorlogtoestand volgde. Bij een langzaam op gang komende oorlog zou er ruimschoots de tijd zijn om het wapenhandwerk te leren. Volgens meerdere sprekers en schrijvers zou ook de welgestelde als de nood aan de man was zijn taak bij de verdediging van vaderland vrijmoedig ter hand nemen. 6

In vredestijd daarentegen moest het mogelijk zijn zich te laten vervangen. Persoonlijke dienstplicht zou in vredestijd juist ongelijkheid creëren, omdat diegene die zich liet vervangen voorbestemd was voor "liberale" beroepen, waarvoor een langdurige en kostbare opleiding vereist was. Het zou niet in het belang van de burger zijn en allerminst in die van de staat een dergelijke opleiding te verstoren. De tijd van de burger was kostbaar. Een aantal maanden uit zijn leven was niet op én lijn te stellen met een zelfde periode uit het leven van de eenvoudige man uit het volk, die ook nog eens beter gekleed, gevoed en gehuisvest werd dan hij normaal gewend was. Uit deze sociale en economische rechtvaardiging van het systeem van plaatsvervanging spreekt de "opportunity costs" gedachte van de dienstplicht. Deze gedachte wordt in hoofdstuk 4 nader uitgewerkt en toegepast op onze tijd.

Het systeem van plaatsvervanging was volgens velen ook politiek nuttig doordat het de lagere klassen hielp aan een werkkring, waartoe bijna iedereen geschikt was. Tevens verminderde dit systeem het gevaar voor de staat dat door de vele ledige handen van de eenvoudige man zou kunnen ontstaan. Daarnaast beschikte een remplaçant over een hoger moreel, omdat hij zich vrijwillig voor de dienst had aangeboden. Ook was het systeem van plaatsvervanging juridisch onaantastbaar, omdat plaatsvervanging geheel op basis van vrijwilligheid ging ${ }^{7}$

Tegen de uitvoering van het systeem van plaatsvervanging bestond wel veel bezwaar. De inningskosten waren zeer hoog. In geschriften uit de negentiende eeuw worden deze bezwaren, de vele ongemakken en de zorgen die zij gaf voor diegene die zich liet vervangen breed uitgemeten. Het vinden van een plaatsvervanger en de rompslomp die dat meebracht was een groot probleem. Spits ${ }^{8}$ geeft van deze rompslomp een mooi voorbeeld dat hier onder volgt. Uit dit voorbeeld komen niet alleen de vele ongemakken van het systeem van plaatsvervanging naar voren, maar is tevens op te maken waarom het in die tijden heel moeilijk was het leger met vrijwilligers te kunnen vullen.

"Hoeveel omslag gaf de hele procedure niett Men kon zich een remplaçant door een 'zielverkoper' bezorgen; men kon er ook eén zelf zoeken. Was men in het bezit van een remplaçant, dan begon de ellende pas. Dan volgde de levering aan de staat. Die taak moest men persconlijk vervullen. Men diende in gezelschap van de man zich naar de zittingszaal van de militieraad te begeven om hem te laten keuren. Vervolgens moest men hem nog omtrent veertien dagen in bewaring houden. Van geluk mocht men spreken als men hem na dat tijdsverloop terugvond, want niet zelden gebeurde het, dat men hem op de dag van de levering vruchteloos zocht. Het verdiende aanbeveling door de militiewet gemachtigd te worden hem tot die dag op te sluiten. Kruseman, schrijver van een in 1853 verschenen bro-

\footnotetext{
6Zie onder andere: Handelingen wan de Tweedế Kamer der Staten Generaal, 1847-1848, blz. 808; I.M. Engelberts, Moet de platswervanging bij de militie worden afgesehaft, Nijmegen, 1848, blz. 22, en A. Kruseman, Over de nationale militie en remplacement, Amsterdam, 1853, blz, 43.

7 Het is nog eens goed op te merken dat het hies handelt om de voorclelen wan het systeem van dienstplicht met. plaatsvervanging boven het systeem wan dienstplicht zonder plaatsvervanging en niet om de voordelen van een vrijwilligersleger boven een dienstplichtigenleger. De argumenten zijn mamelijk exact het zelfde in het geval van de laatste discussie.

8 spits, blz, 193-195.
} 
chure $\mathrm{e}^{9}$, schetst ons het volgende, hiler wat verkort weergegeven tafereel met schrille kleuren wat een eerzame huisvader, die zijn zoon doet vervangen, zo al niet overkomen kan.

Op een herfstavond zit men gezellig en famille bijeen. Het is buitenshu is koud en guw, thatr des te gezelliger ent tecoredener zit en proat men daurbinnen.

Men spreekt ower de gebeurtenissen wan de dag, over de voorwitzichtext wan de oudiste zoon des frutzes, die gelukkig nog een plaatsvervanger hegft kuwnen vinden, over het geld dat die kost en ower het ongemak, dat men heeft als men zich van de dienst wil beurijden. Redds is de atwond waor een groot gedelte verstreken en het is vrij laat. Datar wordt echter nog gescheld.

Wie daar nog zo laat kon wezen? Doch een gedienstige komt bistnen wet het onheilspellende bericht, dat daar de remplacant van de jongeheer is.

Kart darop komt met ongestadige tred een man, wien de ontucht zijn stempel op het gelant heeft gedrukt, de huiskamer binnen, een mens innerlijk slecht en bedorwen, nuar van witwendige bouw goed en geschikt woor soldaat. Het blijkt dat hil nog enig vertier zoekt en met de heer des huizes en diens zoon "een klaverjassie" will leggen. Met verkropte spijt wordt an dat verzoek voldann. Nadat men enige tijd om trit grof geld had gespeeld, haalt de man om nizt in slaap te vallen een zwort eirdje pijp en ieis wat hij tabak noemt wit de zak, beginit te roken en vervult blazende als een andere Aeolus met stinkende walm de sierlifke kawer.

Toen hij enige tijd onder het spelen zwijgend had doorgerookt, scheen hij een onaangersame smalk in de mond te krijgen. Hij uroeg alihuns: 'Zeg es, Mehreer, heb wwe nog van die lekkere wijn pant laatst?'

"Neen, man', is het zo bedard mogelijke antwoord, 'die is op en daar hebt gij uw deel wel wan gehtad.'

'Ja, da's wat en hij was goed ook. Maar geef dan maar wat anders. Jouw pons zal ook wel goed zijth, niet waar? Maur drinken mot ik hebben voor den d....! Want mijm keel is zo droog als een dagarder."

Men is zo goed niet of men doet in de late avond nog de geuraagde drank halen. Doch om kort te gann, nadat ment nog een prat uren langer had doorgespeeld en met drinken en klinken met de gast, zijn flauwe en gemene taal had moeten aurhoren, begint de remplacant slaperig te worden en gaat hij eindelijk heen met ettelijke guldens in zijn $z a k$, net een oud vest en dito pet van de jongeheer onder de arm en met een kledingstuk aan, dat hij nodig had en dat hif 'niet ont te howwen' zoals hij zei, maar slechts te leen had gevrangd van de vader.

Met dit alles is echter het leed niet geleden. De zwaar bezachte huisvader wachten andere beproevingen. Hij heeft zich nog met een storting in de kas wan de naastbijgelegen ontvanger te bemoeien en de minuut van het contract met zijn remplaçant aan de beoordeling van de militieraad te onderwerpen. Eerst dan kan hij over gaan tot het finale contract. Gedurende de achttien maanden daarenboven blijft hij, eer hij gerust kon zijn, eer hij van de zaak af is van de goede trouw, ja zelfs van het eenvoudige bon vouloir van zijn remplaçant afluankelijk. Hij blijft aansprakelijk voor de man en moet zich de last getroosten een ander aan te bieden, te laten keuren enz. in geval het zijn remplaçant behaagt te deserteren. Een dusdanige last kan hem ook nog te beurt vallen bij aan de remplaçant opgekomen gebreken met het onderscheid of die in of buiten dienst en ter gelegenheid van de dienst of onafhankelijk van de dienst zijp antstaan. ${ }^{\text {"10 }}$

Indien we ons verplaatsen in de gedachten van de remplaçant kunnen we op basis van het 'opportunity-costs'-beginsel beredeneren waarom hij zo handelt. Het heeft immers voor hem grote nadelen indien hij direct als vrijwilliger in het leger dienst wil. treden, omdat hij via het systeem van plaatsvervanging een veel hogere vergoeding voor zijn diensten kan krijgen. Een remplaçant weegt de baten van een directe indiensttreding in het leger af tegen de baten die hij ontvangt door eerst de dienstplichtloting af te wachten en zich vervolgens aan te bieden als remplaçant. De kans dat lemand in militaire dienst moest was niet groot en dan valt de afweging, tussen een beloning volgens de eigen lage "opportunity costs" en de "opportunity costs" van een rijke die een vervanger zoekt, al snel uit in het nadeel van het directe vrijwilligerschap.

\footnotetext{
9 Zilia voetrionot 6

102 ie voetmoot 8 .
} 
Door het systeem van plaatsvervanging krifgt hij een veel grotere beloning. Of in economische termen: de verwachte waarde van vrijwillig in dienst treden is lager dan de verwachte waarde van de dienstplicht.

De constatering van Campagne in de vorige paragraaf dat biy een gebrek aan vrijwilligers het Napoleontische conscriptiestelsel had gezegevierd is feitelijk gezien onjuist. Het gebrek aan "echte" vrijwilligers werd veroorzaakt door het plaatsvervangingssysteem en niet direct door de dienstplicht op zich. Remplaçanten genoeg, als er maar betaald werd. Daarnaast werd het gebrek aan vrijwilligers nog eens schrijnender, doordat de voorwaarden voor vrijwillig in dienst treden minimaal waren. Aan verzorging en huisvesting werd weinig aandacht besteed, de premie die de soldaat als vrijwilliger kreeg was te laag en zijn vooruitzichten voor de toekomst waren bedroevend. In de negentiende eeuw kon de krijgsmacht op de arbeidsmarkt dus niet concurreren met de burgermaatschappij. De krijgsmacht ontbeerde immers ook de prikkels tot concurrentie, omdat de voorziening van arbeidskrachten wettelijk geregeld was. Een situatie warmee men hedentendage ook geconfronteerd wordt in de krijgsmacht. ${ }^{11}$

Met de militiewet van 1861 werden vele bepalingen in het systeem van plaatsvervanging verzacht. Voor een aantal kamerleden ging dit echter nog niet ver genoeg. Zij keken naar het buitenland waar de plaatsvervanging door simpele afkoop werd vervangen. Dit was volgens hun de enige weg om de ongemakken die aan plaatsvervanging verbonden bleven geheel weg te nemen. De voorstanders van afkoop waren in die tijd vooral te vinden onder de aanhangers van een reactionair-conservatieve groepering in de Tweede Kamer. Ze streefden wat de legerinuichting betreft naar het herstel van het oudle stelsel, een geheel uit beroepssoldaten bestaand leger. De dienstplicht wezen ze af. Wel kon de burgerij te wapen worden geroepen in het geval van een vijandelijke invasie. Voor het overige moest de krijgsdienst door werving van vrijwilligers van personeel worden voorzien.

Volgens Kamerlid Van Goltstein bracht de verplichte krijgsdienst niets dan verderf:

"De lotelingen werden aan hun huisgezinnen onttrokken, gestuit in hun maatschappelijke ontwikkeling en gestoord in het aanleren van een beroep. Keren zij uit de dienst terug, dan hebben zij de lust tot arbeid verloren en zijn zij voor het huiselijke verkeer ongeschikt".12

Daarnaast was de kwaliteit van het leger zorgwekkend. Dit lag vooral aan de plaatsvervangers. Van Gollstein zag in hen ook de kiem aanwezig van te overdadig drankgebruik.

"De vervanging van de remplacering door afkoop zou al dat kwaad kunnen keren. De regering zelf zou de plaatsvervangers moeten leveren en uit het haar betalde afkoopgeld een fonds moeten vormen, waaruit ten behoeve van het staande leger de kosten van een verhoogde premie en solldij en van verbe* terde pensioenen konden worden bestreden. Dit zou voor alle partijen voordelig zijn. Het parate deel van de krijgsmacht zou in sterkte toenemen en er, door verzwaring van de eisen, kwalitatief op vooruitgaan. De last wan de burger zou wordien verlicht; voor elke vrijwilliger meer zou een dienstplichtige bij huis en akker kunnen blijven. En ook de soldaat zou er wel bij varen; de dreigende spooksels van armoede en gebrek zouden hem niet langer'tegengrijnzen. Dit alles moest te verwezenlijken zijn, want

14 De huidige situatie wordt in hoofdstuk 6 en 7 nader onder de loep genoman.

12 Zie Spits, blz. 196-197. 
de staat zou wat het verkriiggen wan plaatsvervangers betreft met de particuliere maatsehappijen kunnen wedijweren. ${ }^{13}$ Hij hoefde immers geen winst te behalen en kon betere waarborgen geven. 14

Volgens de reactionair-conservatieven in de Tweede Kamer was de afkoop veruit te prefereren. De argumenten die zij aandroegen waren voor de liberalen te weinig dwingend. Voor hen sprak in de allereerste plaats de traditionele afkeer van het professionele leger, die door het stelsel van afkoop nog meer relief zou krijgen. Immers elk jaar zouden er minder dienstplichtigen in het leger worden opgenomen en zouden er minder geoefende millitairen aan de maatschappij worden teruggegeven. In het leger zou de burgerzin worden gedoofd en in de natie de militaire geest verzwakt. De kloof tussen burger-en militaire maatschappij zou nog meer worden verwijd.

Met deze argumenten refereren de liberalen aan de uitgangspunten voor de dienstplicht, zoals deze zijn opgesteld door Machiavelli (1469-1527) in zijn "Dell'arte delle guerra". Machiavelli onderscheidt drie redenen om de dienstplicht te verkiezen boven een vrijwilligersleger: een dienstplichtigenleger zou goedkoper zijn, dienstplicht zou burgerzin kweken en dienstplicht zou er voor zorgen dat niemand de middelen zou hebben een greep naar de macht te doen. Vermaatschappelijking van de krijgsmacht zou er voor zorgen dat de krijgsmacht geen staat-in-de-staat zou worden.

De discussie die tussen de liberalen en reactionair-conservatieven ontstond werd uiteindelijk gewonnen door de tegenstanders van afkoop met als voornaamste argument dat afkoop de regering de zekerheid zou ontnemen dat ze het contingent elk jaar volltallig zou krijgen.

"Als het inderdaad waar bleek, wat ze vreesde, dat de hoofdoorzaak van de geringe dienstneming niet in de lage premie en de te geringe soldij was gelegen, maar in de traditionele afkeer van het soldatenberoep met daarbij de mogelijkheid om op andere wijze de kost te verdienen, dan zou de optimistische voorspelling van de voorstanders wan afkoop, dat er steeds genorg vrijwilligers zouden zijn, wel eens gelogenstraft kunnen worden. ${ }^{15}$ Bowendien, hoe moest de prijs voor afkoop worden bepaald? Was ze te hoog ${ }_{n}$ dan werd het een privilege voor zeer vermogende lieden. Werd ze te laag gesteld, dan zouden te velen er gebruik van maken en daardoor grote tekorten ontstaan. Men zou die tekorten kunnen aanvullen door de sterkte van de lichting op te voeren; maar dan zou de minvermogende weer de dupe zijnn". 16

De regering werd daarbij ondersteund door de ervaringen in het buitenland met de afkoop die niet echt bemoedigend waren. En zo bleek de Kamer niet bereid de conservatieven te volgen en bleef het systeem van plaatsvervanging in stand. Overzien we de discussie in de Tweede Kamer van 1861 dan blijkt dat in de twintigste eeuw de argumenten voor en tegen dienstplicht weinig veranderd zijn. Zowel in de discussie rond de dienstplicht van 1976 als van 1992 kwamen de reeds in 1861 aangevoerde argumenten naar voren. 17

\footnotetext{
13 De praktijken van de particuliere matschappijen, instellingen die zich bezig hielden met de tussenhandel en toelovering van remplaçanten, waren berucht. Ze gingen met een aamaienlijk deel van thet voor plaatsvervanging gevraagde bedrag strijken. De remplaçant ontving natw welijks de helft.

14 Handelingen van de Tweede Kamer der Staten Generaal, zitting 1860-1861, blz. 759, in: Spits, blz 197.

Door in het geciteerde stulk uit 1864 het woord afkoop te vervangen door personele- of inkomstenbelasting kan de gehele discussie ever de dienstplicht naar onze tijd verplaatst wowden, daar ook in onze tijd de discussie gaat over de varvanging van oem belasting-in-natura door een belasting in geld.

15 Zie hoofdstuk 6 voor een uitgebreid behandieling van de arbeidsvoorwaarden en arbeidsomstandigheden en het verband met de aantreklicelijkheid van het soldatenberoep.

16.Handelingen van de Tweeda Kamer der Staten-Generaal, zitting 1860-1861, blz. 910 in: Spits, blz. 199.

17 Hot is opvallend te moeten constateren dat er na 130 jaar in de dienstplichtdiscussie van 1992 dezelfde argumenten worden aangevoerd. Toch is noodzakelijk het personeelsbeleid nadrukkelijker onder de loep te nemen,
} 


\section{§3.3. De periode na 1870}

De Frans-Duitse oorlog (1870-1871) bracht in Nederland een mobilisatie tot stand: Die mobilisatie bracht vele wantoestanden in het leger aan het licht. Het mobilisatieverslag van 20 september 1871 onderkent drie grote fouten ${ }^{18}$ : te zwakke encadrering, te geringe ontwikkeling van de dienstplichtigen (een vijfde deel van de mannen werd gevormd door nummerverwisselaars of plaatsvervangers) en ongeschiktheid van de schutterij. Uit én en ander concludeerden legerleiding en regering in de eerste plaats de noodzaak van persoonlijke dienstplicht, zonder het systeem van plaatsvervanging.

De man die uiteindelijk de echte persoonlijke dienstplicht invoerde, was Minister van Oorlog K. Eland. Bij de wet van 2 juli 1898 werd de persoonlijke dienstplicht werkelijkheid. Het Nederlandse leger ontwikkelde zich vanaf dat moment tot een bijna zuiver dienstplichtigenleger met slechts een zeer kleine kern beroepspersoneel.

Ook na de Tweede Wereldoorlog bleef de dienstplicht bestaan. De dienstplichttijd varieerde in de periode 1945-1966 van 24 tot 18 maanden. Vaak werd de dienstplichttijd aangepast aan externe omstandigheden veroorzaakt door de Koude-Oorlog. Ook speelden arbeidsomstandigheden in de burgermaatschappij een rol bij verkorting of verlenging van de duur van de dienstplicht.

Vanaf $1960 \mathrm{kwam}$ de dienstplicht weer in de belangstelling te staan van de politiek. Immers in de honderd jaar na de discussie in de Tweede Kamer tussen liberalen en reactionair-conservatieven was er voor de dienstplichtigen weinig veranderd. De beloning van dienstplichtigen was niet meer dan zakgeld, de arbeidsomstandigheden waren slecht, dienstplichtigen werden in tweede-hands militaire treinen vervoerd en door beroepsmilitairen werden ze als tweede-rangs-burgers behandeld. De veranderingen vanaf 1960 passen in het algemene beeld van die tijd, maar hebben in de krijgsmacht tevens een specifieke oorsprong. In het begin van de jaren 60 werd het indelingssysteem van dienstplichtigen geautomatiseerd. Door de selectie van de computer kwamen met name hoger opgeleide mensen op lage functies terecht waar zij vroeger bij de handmatige indeling nooit terecht zouden zijn gekomen. Deze nieuwe selectie-wijze zorgde er ongezien voor dat de discrepantie tussen opleiding en functie toenam en daarmee ook de uiting van onvrede door de dienstplichtigen. In deze atmosfeer ontstond op 4 augustus 1966 de Vereniging Van Dienstplichtige Militairen (VVDM).

De VVDM pakte in 1966 de handschoen op waar Kamerleden als Van Goltstein deze in 1861 hadden moeten laten liggen. Oorspronkelijk als belangenbehartiger, maar later veel meer als vakbond van dienstplichtigen zette de VVDM zich in voor de verbetering van de arbeidsvoorwaarden en arbeidsomstandigheden van de dienstplichtigen. Al snel werden er successen geboekt op zowel materieel als immaterieel terrein. De normen en waarden van de burgermaatschappij dienden zich volgens de VVDM te weerspiegelen in de krijgsmacht. Dat zij daarbij felle tegenstand van de beroepsmilitairen kon verwachten was voorspelbaar. Vooral in macht en status werden de ambtenaren van het Ministerie van Defensie beperkt door de activiteiten van de vakbond. ${ }^{19}$ Tegelijkertijd vond de VVDM haar plats in het publieke besluitvormingsproces door plaats te nemen in de overlegstructuren met het Ministerie van

omdat juist daar het grote probleem light, zoals de reactionair-conservatieven in 1861 reeds constateerden. Voor een uitgebreide behandeling van dit probleem zie hoofdstuk 6 en 7 .

18 Zive Carnpagne, bliz 8-9.

19 Zie voor de theoretische analyse hoofdstuk 2,64 
Defensie, door lobbyactiviteiten naar de politici toe en door aansluiting bij de landelijke vakbondscentrale FNV.

De VVDM is jarenlang voorstander geweest van de dienstplicht: de dienstplicht was de ideale manier voor de binding van de krijgsmacht met de maatschappij. Aan de andere kant werkte zij, onbewust, aan het bewerkstelligen van een krijgsmacht met vrijwilligers, door te proberen alle arbeidsomstandigheden van dienstplichtigen zoveel mogelijk in overeenstemming te brengen met die van de vrijwilligers en de burgermaatschappij.

In 1992 heeft de VVDM haar oude visie op de dienstplicht dan ook verlaten en richtte zij zich volledig op die facetten van de krijgsmacht die er voor moesten zorgen dat een vrijwilligersleger daadwerkelijk tot stand zou kunnen komen.

Sinds 1960 is de dienstplichtdiscussie in Nederland ook weer op gang gekomen. In 1976 onderzocht de commissie Mommersteeg de dienstplicht en concludeerde dat de dienstplicht in leder geval op korte termijn gehandhaafd diende te worden. Na de val van de Muur in Berlijn en het einde van de Koude Oorlog die daarop volgde, werd in 1991 een nieuwe commissie onder leiding van de toenmalige Commissaris van de Koningin in Drenthe Wim Meijer ingesteld. De commissie kwam na een jaar onderzoek tot de conclusie dat de dienstplicht niet kon worden afgeschaft. De commissie kwam met vier redenen waarom niet zou moeten worden gekozen voor een vrijwilligersleger. (1) De internationale veiligheidssituatie verdraagt zich niet met de afschaffing van de dienstplicht, (2) er is een onvoldoende aanbod op de arbeidsmarkt voor beroepsmilitairen waardoor het vrijwilligersleger onvoldoende kan worden gevuld, (3) een vrijwilligersleger kost te veel geld en (4) de grondwet moet veranderd worden wil de dienstplicht daadwerkelijk worden afgeschaft.

Niettemin was het parlement deze keer van mening dat de dienstplicht toch moest worden afgeschaft. De regering is in dit standpunt meegegaan en heeft besloten dat op 31 december 1997 de laatste dienstplichtige de deur van het kazernecomplex achter zich kan dichttrekken.

\section{$\$ 3.4$. Het voortbestaan van de dienstplicht in een democratische omgeving 20}

In hoofdstuk 2 hebben we gezien dat de dienstplicht geen vaststaand gegeven is, maar de uitkomst kan zijn van een democratisch besluitvormingsproces. Ook het voortbestaan van de dienstplicht staat onder invloed van het politieke besluitvormingsproces. Deze paragraaf laat een model zien dat op eenvoudige wijze de politieke origine en het voortbestaan van de dienstplicht beschurijft. Het model sluit aan bij het model van paragraaf 5 uit hoofdstuk 2 . Met behulp van het model wordt naar voten gebracht waarom de dienstplicht nu reeds 180 jaar bestaat en waarom discussies over de dienstplicht in 1861 en 1992 feitelijk dezelfde strekking kunnen hebben.

\section{\$3.4.1. Het model}

Het model probeert een verklaring te geven voor het feit waarom de dienstplicht blijft voortbestaan in een democratische omgeving. Het model dat aansluit op het model van paragraaf 5 uit hoofdstuk 2 dient daarom voorspellende kracht te hebben. Allereerst zal een eenvoudig model worden gepresenteerd. De veronderstellingen die

20Deze paragraaf is giebascerd op Robert D. Tollison, The Political Economy of the Military Draft, in: Buchanan en
Tollison, Theory of public choice, Ant Arbor, 1972, blz. 302-314. 
ten grondslag liggen aan het eenvoudige model worden daarna aangepast aan de realiteit. Daarbij wordt gekeken of het model zijn verklarende kracht nog behouden heeft. Individuen in het model baseren hun stemgedrag op het veronderstelde effect dat de dienstplicht heeft op hun huidige welvaartspositie. $Z \mathrm{ij}$ kunnen daarbij de wel-

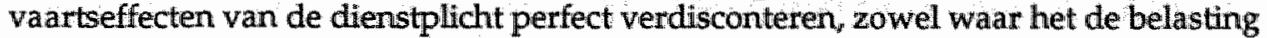
in natura door de dienstplicht als de potentiële subsidie door lagere belastingen na de dienstplicht betreft.

In het model is verder verondersteld dat het kiezersbestand rechthoekig qua leeftijd verdeeld is. Iedere leeftijdsgroep kent dus evenveel personen en de dienstplichtigen hebben stemrecht. De keuze voor of tegen dienstplicht is het enige onderwerp dat de collectieve besluitvorming behelst en alle kosten die aan het besluitvormingsproces verbonden zijn kunnen verwaarloosd worden. Deze veronderstelling sluit complicaties als coalitievorming, stemmenruil en politieke besluitvormingskosten uit.

Tenslotte wordt verondersteld dat iedere goedgekeurde dienstplichtige de dienstplicht ook daadwerkelijk vervult en dat deze groep voldoende mensen levert om aan de behoefte van de krijgsmacht te kunnen voldoen. Bij de initiêle keuze voor of tegen dienstplicht gelden dezelfde veronderstellingen zoals wij reeds zagen in hoofdstuk 2, paragraaf 5. Voor de kiezers ouder dan 18-20 jaar, de dienstplichtige leeftijd, levert het instellen van de dienstplicht een belastingbesparing op. Deze groep zal de dienstplicht steunen.

Dienstplichtigen zullen de netto contante waarde van de dienstplicht moeten calculeren, dat wil zeggen zij moeten de balans opmaken van verloren inkomen tijdens de diensttijd en de belastingsubsidie die de dienstplichtige als veteraan ontvangt na zijn diensttijd. Verondersteld wordt dat deze balans negatief is. De groep dienstplichtigen zal dus tegen de dienstplicht stemmen. Afhankelijk van de grootte van de groepen voor en tegen dienstplicht zal dienstplicht ten uitvoer worden gebracht. ${ }^{21}$ Indien de dienstplicht eenmaal ingevoerd is; kan gekeken worden naar de vermogenspositie van de individuele kiezer om te zien of de dienstplicht blijft voortbestaan gedurende een langere periode.

Bij het voortbestaan van de dienstplicht wordt verondersteld dat iedere 2 jaar de dienstplicht bekrachtigd moet worden met behulp van een referendum. ${ }^{22}$ Het voortbestaan van de dienstplicht hangt bij het twee jaarlijkse referendum af van het stemgedrag van de huidige dienstplichtigen, indien zij hun 2 jaar diensttijd hebben vervuld en veteranen (begunstigden) worden in het collectieve proces. Het stemgedrag van de veteranen is essentieel, omdat de verplichting dat iedereen moet dienen betekent dat in de toekomst het gehele niet-dienstplichtige deel van het kiezersbestand veteraan is.

De veteraan bevindt zich bij een referendum in een totaal verschillende situatie, dan hij aantrof in de initiële periode. De last van de dienstplicht is nu een "sunk cost" geworden, die in de initiële periode nog subjectief door iedere dienstplichtige gekapitaliseerd werd. In de volgende perioden zijn deze verzonken kosten echter irrelevant met betrekking tot de beslissing over dienstplicht door de veteraan. Hoewel de toekomstige veteraan de verwachte opbrengst van de toekomstige subsidies kapitaliseerde in de initiële periode, is de continuering van de subsidie afhankelijk van het keuzegedrag van diezelfde veteraan in alle toekomstige referenda. Voor de veteraan

\footnotetext{
21 Zie ook hoofdstuk $2, \$ 5.1$.

${ }^{22}$ Hierbij geldt dat de beslissingstegels ongewijzigd blijven, dat er nie ts verandert in de leeftijdswerdeling van de kiezers en dat de voorwaarden woor de dienstplichitigen ook dezelfde zijn.
} 
geldt dat de opbrengst van de dienstplicht in alle post-dienstplicht perioden positief is en zal hij rationeel kiezen voor voortzetting van het proces zonder rekening te houden met zijn stemgedrag in de initiêle periode.

De dienstplicht creëert zijn eigen voortbestaan, omdat iedere generatie van 18-20 jaar er belang bij heeft dat het proces na afloop van de dienstplicht voortduurt. Dit voortbestaan wordt in de praktijk onder andere bevestigd door het verloop van de dienstplichtdiscussies in 1976 en 1992.

\section{\$3.4.2. Aanpassingen van het model}

Het model in paragraaf 3.4.1. kent een aantal veronderstellingen die in deze paragraaf aangepast worden aan de realiteit. De centrale veronderstelling in het model betreft de perfecte verdiscontering van de belasting-in-natura en de subsidie: Zonder deze veronderstelling kunnen de effecten van de dienstplicht verstoord, illusoir of onzeker worden voor een deel van het kiezersbestand. Het keuzeprobleem wordt meer onvoorspelbaar onder deze omstandigdeden. Het meest waarschijnlijk is dat de belasting-in-natura accuraat ingeschat wordt, maar de subsidie niet. De belasting is een duidelijk persoonlijk iets, waar een individu weinig problemen mee heeft deze op te merken en te kapitaliseren. De subsidie bestaat echter uit een vermindering van de totale uitgaven, waarvan de lasten worden verdeeld over de gehele gemeenschap. Het is heel goed mogelijk dat een individu zich niet bewust is van de subsidie. Zou niemand zich van deze situatie bewust zijn, dat zou zelfs de initiële beslissing om de dienstplicht in te stellen niet doorgaan. Alleen in het geval dat de subsidie voor alle niet-dienstplichtigen geen waarde heeft, zullen de dienstplichtigen er voor kunnen zorgen dat de dienstplicht afgeschaft wordt. Zolang de groep niet-dienstplichtigen zich bewust is van het bestaan van de subsidie zal de situatie, zoals beschreven in het model, voortbestaan. En het is zeker niet onrealistisch te denken dat dit inderdaad het geval is. Zeker in tijden van discussie over de dienstplicht beseffen niet-dienstplichtigen de waarde van de subsidie.

Ten tweede zal het publieke besluitvormingsproces ingewikkelder worden, indien dienstplicht niet het enige onderwerp is waarover beslissingen genomen dienen te worden. In zo'n geval zullen coalities en stemmenruil een belangrijke rol gaan spelen, waardoor besloten kan worden tot het afschaffen van de dienstplicht. Met name in die gevallen waarin de dienstplichtproblematiek een grote actieve minderheid vertegenwoordigt tegenover een grote niet-actieve meerderheid, neemt de waarschijnlijkheid van de afschaffing van de dienstplicht als onderdeel van stemmenruil en coalitievorming toe. Anderzijds kunnen er door het ter discussie stellen van de dienstplicht ook weer nieuwe coalities ontstaan die het voortbestaan van de dienstplicht garanderen. Deze nieuwe coalities kunnen ontstaan, omdat door de discussie nieuwe belangen naar voren kunnen komen, die daarvoor niet op de voorgrond traden. ${ }^{23}$

Ten derde is er de veronderstelling dat iedereen dient die daarvoor fysiek geschikt is. Indien niet iedereen wordt opgeroepen, zoals de praktijk is, zal de groep niet-dienstplichtigen nog groter zijn dan in het oorspronkelijke model aangenomen werd en zal de afschaffing van de dienstplicht niet snel te verwachten zijn. Is daarentegen het aantal dienstplichtigen in de veronderstelde leeftijdsgroep 18-20 jaar onvoldoende en wordt de diensttijd uitgebreid tot bijvoorbeeld de 21 -jarigen dan is de kans

\footnotetext{
23 De politieke praktijk in Nederland laat zjern dlat het dienstplichtrraagstuk vrij onafhankelijk van andere onderwerpen behandeld wordt en dat do mogelijkheid wan stemmenruil laag moet worden ingeschat.
} 
dat de dienstplicht afgeschaft wordt weer groter geworden. Indien immers door het verplaatsen van de leeftijdsgrens een groep wordt bereikt die tegen het instellen van de dienstplicht is, kan het gebeuren dat het hele systeem als een kaartenhuis in elkaar klapt. In de praktijk zal dit echter niet zo snel gebeuren, omdat door een kleine verplaatsing van de leeftijdsgrens reeds voldoende dienstplichtigen bereikt kunnen worden.

Tenslotte is er de veronderstelling dat alle dienstplichtigen een negatieve waardering van de dienstplicht hebben in de initiële periode. Doch ook hier kunnen realistische verschijnselen als patriotisme deze opvatting doorkruisen en zal sneller worden ingegaan tot instelling van de dienstplicht of het laten voortbestaan van de dienstplicht.

De aanpassingen van het model laten zien dat de conclusie welke voortkomt uit het eenvoudige model slechts weinig aan verklarende kracht in boet. De aanpassingen laten zien dat de conclusie van het voortbestaan van de dienstplicht veelal nog versterkt wordt indien de veronderstellingen aangepast worden aan de praktijk.

Herziening van de dienstplicht is nog altijd een politiek proces en deze paragraaf heeft laten zien waarom de dienstplicht kan ontstaan en voortbestaan in een democratische omgeving. Tevens heeft zij laten zien dat de historische ontwikkeling van de dienstplicht zoals deze naar voren is gekomen in de eerste vier paragrafen van dit hoofdstuk niet zomaar een gebeurtenis is. Tenslotte kunnen we met behulp van dit model een verklaring geven voor het feit dat de discussies over de dienstplicht in 1861 en 1992 zo weinig qua inhoud verschillen.

\section{\$3.5. Samenvatting}

In dit hoofdstuk is het ontstaan en het voortbestaan van de dienstplicht onder de loep genomen. De dienstplicht is geïmporteerd uit Frankrijk, maar werkelijkheid geworden door de koppeling van de dienstplicht aan het systeem van plaatsvervanging. Pogingen de dienstplicht af te schaffen mislukten door een gebrek aan prikkels bij zowel de politici als de krijgsmacht. $\mathrm{Na} 1861$ heeft dienstplicht vrijwel zonder discussie kunnen voortbestaan tot het begin van de jaren 60 in de twintigste eeuw. Vanaf dat moment ontstond mede door inspanningen van de dienstplichtigen een veranderingsproces. Dit veranderingsproces heeft ook het publieke besluitvormingproces beinvloed getuige de onderzoekscommissies die vanaf 1966 met de dienstplicht bezig zijn geweest. Toch is het de vraag of de dienstplicht hierdoor afgeschaft zal worden. De groepen die profiteren van de dienstplicht zijn veel groter dan de groepen die de last van de dienstplicht ondervinden. Daamaast zijn dienstplichtigen jong en hebben vrijwel geen macht in het publieke besluitvormingsproces. Dit wordt nog versterkt indien we ons beseffen dat de dienstplicht verzonken kosten zijn na het moment dat de dienstplicht voltooid is. Veteranen zullen pleiten voor het voortbestaan van de dienstplicht omdat zij daar voordeel van hebben. Niet alleen in geld maar ook in termen van macht. Het voortbestaan van de dienstplicht zorgt er voor dat de groep veteranen niet uitsterft en zij haar machtspositie kan behouden indien zij deze heeft.24 Ondanks het feit dat de Commissie-Meijer in 1992 in haar dienstplichtrapport conclu-

\footnotetext{
24Een voorbeeld van deze groep in Nederland zijn de KNIL-militairen uit het voormalige Nederlands-lindie die nog steeds een krachtige groep vormen en de velle ingezonden stukken in de kranten door voormalige milltairent die pleiten voor het behoud van de dienstplicht. Ook binnen het Ministerie van Defonsile is er veel aandacht woor de vetteranen, zoals blijkt tuit de speciale workgroep "Post-actieven" "walke binnen die overleggstucturen van het Ministerie van Defensie haar eigen plaats heeft.
} 
deerde dat de dienstplicht diende voort te bestaan, was het parlement en de kabinet Lubbers-3 nettemin toch van mening dat de dienstplicht afgeschaft diende te worden om per 1 januari 1998 definitief over te stappen op een vrijwilligersleger. 


\section{De dienstplichtbelasting}

"Dienstplicht is grof onrechtvaardig, hopeloos inefficiënt en maakt de mannelijke bloem der natie een jaar lang tot doperwtjes."

Prof. Dr. J. Theeuwes, in: Trouw, 20 september 1991.

Dienstplicht voorziet in een instrument om de budgettaire kosten van militaire arbeid laag te houden en kan worden gezien als een instrument van economische politiek. Dienstplicht vermindert de belasting die door de maatschappij opgebracht zou moeten worden, en kan dus impliciet worden gezien als een belasting. Een gedwongen bijdrage zonder dat daar direct een prestatie tegenover staat door de partij die de bijdrage in ontvangst neemt. De dienstplicht voorziet in de mogelijkheid de markt voor de vulling van de krijgsmacht terzijde te schuiven, waardoor zij tevens een aantal economische vraagstukken opwerpt. Dit wil niet zeggen dat de keuze voor of tegen dienstplicht alleen op basis van economische redenen geschiedt, maar het betekent dat het gebruik van de dienstplicht economische gevolgen heeft voor zowel de krijgsmacht in het bijzonder als de samenleving in het algemeen. Belastingen hebben als kenmerk dat zij inefficiënties kunnen doen ontstaan, hoe noodzakelijk de belastingen ook zijn. In hoofdstuk 1 hebben we globaal gezien welke inefficiënties er door de dienstplicht kunnen voorkomen. In dit hoofdstuk worden een paar van deze inefficiënties nader onder de loep genomen. Met name zal het hier gaan om de omvang van de dienstplichtbelasting. Daarnaast kijken we ook naar de verdeling van de dienstplichtbelasting en de kosten die te maken hebben met het innen, ontduiken en ontwijken van de dienstplichtbelasting.

\section{\$4.1. De omvang van de dienstplichtbelasting ${ }^{1}$}

Bij de produktie van het collectieve goed defensie spelen de kosten van de krijgsmacht vanzelfsprekend een belangrijke rol. Er zijn verschillende manieren om tegen de kosten van de krijgsmacht aan te kijken, waarvan er in ons geval twee specifiek belangrijk zijn. De eerste maatstaf is de budgettaire last van militaire arbeidskrachten, die opgebracht moet worden door de belastingbetaler. De tweede maatstaf - welke

\footnotetext{
1 Deze paragraaf is ondermeer gebaseerd op: S.H. Altman en A.E. Fechter, "The Supply of Military Personnel in the Absence of the Draft", American Economic Review, mei 1967; A.C. Fisher, "The Cost of the Draflt and the Cost of Ending the Draft", American Economic Review, juni 1969; W.L. Hansen en B.A. Weisbrod, "Economics of the Military Draft", The Quarterly Journal of Economics, vol. 81, 1967; C. Lingle, "On the real Costs of Milltary Conscription", South African Journal of Economics, vol. 57, 1989; W. Oi, The Economic Cost of the Draft", American Economic Review, mei 1967; A. Rowx, "The Economics of Alternative national Service", South African Joumall of Economics, wol. 59, 1991; R.V.L. Cooper, Military Manpower and the All-vol untear force, Rand Corporation, Santa Monica, 1977.
} 
minder zichtbaar is, maar niettemin des te belangrijker uit maatschappelijk oogpunt betreft de economische kosten van de militair. De economische kosten van de militair zijn daarbij gedefinieerd als de waarde van de arbeid die binnen de krijgsmacht wordt gebruikt. Het onderscheid tussen economische en budgettaire kasten is vooral belangrij) gedurende perioden waarin er dienstplicht bestaat, omdat, zoals we reeds eerder gezien hebben, de dienstplicht de krijgsmacht in staat stelt minder dan het marktloon voor militair personeel te betalen. In concurrerende of vrije markten zullen de budgettaire en economische kosten in het algemeen gelijk zijn aan elkaar maar als de overheid tussenbeide komt kan het gebeuren dat de twee maatstaven gaan verschillen en in sommige gevallen zelfs aanzienlijk.

$\mathrm{Nu}$ we de economische kosten van een militair gedefinieerd hebben als de "opportunity costs" van lemand die in de krijgsmacht werkt, moeten we bepalen hoe groot deze kosten voor de dienstplichtige precies zijn. Daarvoor kunnen we (1) de "opportunity costs" voor de burgermaatschappij nemen in termen van verloren produktie of (2) de "opportunty costs" van de dienstplichtige zelf.

De reden voor de eerste definitie is dat door de deelname van de dienstplichtige in de krijgsmacht, de burgermaatschappij de produktie mist die hij anders daar voortgebracht zou hebben. Traditioneel en empirisch wordt deze eerste of krappe definitie gemeten als het burgerloon van de dienstplichtige, onder de veronderstelling dat dit loon de waarde vertegenwoordigt van zijn arbeid in de burgermaatschappij.

De reden voor de tweede definitie is dat door het dienen in de krijgsmacht, de dienstplichtige niet alleen zijn burgerloon aan zijn neus voorbij ziet gaan, maar ook de positieve of negatieve niet-geldelijke voordelen van zijn burgerbaan mist. Zo is de dienstplicht niet zijn eigen vrije keuze daar hij gedwongen wordt plaats te nemen in de krijgsmacht, is hij vaak ver van huis en familie en wordt hij in de krijgsmacht anders behandeld dan dat hij in de burgermaatschappij gewend is. ${ }^{2}$ Anderzijds kan hij in de krijgsmacht ook zaken leren, waarmee hij in de burgermaatschappij niet bekend was. Bij het missen van de positieve voordelen uit de burgermaatschappij zegt de dienstplichtige dat hij baalt. De positieve of negatieve niet-geldelijke voordelen worden daarom kortweg "baalpremie" genoemd. De onderkenning van de baalpremie is essentieel voor de hier gehanteerde analyse, omdat uit deze onderkenning naar voren komt dat voor het bepalen van de kosten van de dienstplicht de lasten voor de dienstplichtige het centrale element in de analyse vormen en uit deze lasten daarna de maatschappelijke gevolgen van het gehele instituut dienstplicht kunnen worden afgeleid.

De tweede of brede definitie wordt gemeten als het "reserveringsloon" van de dienstplichtige, waartegen hij bereid is te gaan werken in de krijgsmacht. Het "neserveringsloon" of de aanbodprijs van de individuele dienstplichtige is simpelweg de som van zijn alternatieve burgerloon en de baalpremie. In het vervolg van deze paragraaf zal de brede definitie van de term economische kosten worden gevolgd.

Uit het begin van dit hoofdstuk konden we opmaken dat een belasting een gedwongen bijdrage is zonder dat daar een directe tegenprestatie tegenover staat van de partij die de bijdrage in ontvangst neemt. Deze omschrijving van het begrip belasting is een bewerking van de definitie die Cort van der Linden in 1887 aan de "belasting" gaf:

\footnotetext{
2 In hoofdstuk 6 worden alle elementen wan het beroep soldaat witvoerig onder dle loep genomen ten komen ook de positieve en negatiove niet-greldelijke voondelen uitgebreid aan de orde. Hier is slechts een indicatie opgenomen.
} 
"Bellasting is iedere bijdrage aan de algemene middelen verschuldigd, onafharkelijk van enigen bijzonderen dienst der overheid" ${ }^{3}$

Uit de annotaties bij deze en andere definities van de term "belasting" blijkt dat ook de militaire dienstplicht hieronder begrepen dient te worden." De dienstplichtige wordt gedwongen in de krijgsmacht deel te nemen en ontvangt daarvoor een wedde. De last van de militaire dienstplicht of dienstplichtbelasting wordt dan gekarakteriseerd door het verschil tussen de wedde die de dienstplichtige ontvangt en de "opportunity costs" van de dienstplichtige. Indien wij deze dienstplichtbelasting willen concretiseren dan dienen we te weten hoe hoog het burgerloon, de baalpremie en de wedde van ledere dienstplichtige is.

Tabel 4.1. Burgerloon van een dienstplichtige.

\begin{tabular}{|c|c|c|c|}
\hline $\begin{array}{l}\text { Jaarloonklasse } \\
16-24 \text { jarigen } \\
\text { (gld) }\end{array}$ & $\begin{array}{l}\text { Aantal } \\
\text { jongeren } \\
\text { in } \%\end{array}$ & $\begin{array}{l}\text { Jongens } \\
\text { cumulatief }\end{array}$ & $\begin{array}{l}\text { Dienstplichtigen } \\
\text { absoluut per } \\
\text { jaarloonklasse }\end{array}$ \\
\hline A & B & C & D \\
\hline$<10.000$ & 5,6 & 6.640 & 2.507 \\
\hline $10.000-12.000$ & 6,4 & 14.228 & 2.865 \\
\hline $12.000-12.500$ & 1,6 & 16.125 & 716 \\
\hline $12.500-15.000$ & 9,6 & 27.507 & 4.297 \\
\hline $15.000-17.500$ & 13,9 & 43.988 & 6.222 \\
\hline $17.500-20.000$ & 22,9 & 71.140 & 10.253 \\
\hline $20.000-22.500$ & 21,9 & 97.106 & 9.803 \\
\hline $22.500-25.000$ & 11,0 & 110.148 & 4.924 \\
\hline $25.000-27.500$ & 4,1 & 115.009 & 1.835 \\
\hline $27.500-30.000$ & 1.7 & 117.024 & 716 \\
\hline $30.000-32.500$ & 0,6 & 117.736 & 269 \\
\hline $32.500-35.000$ & 0,3 & 118.091 & 314 \\
\hline $35.000-37.500$ & 0,1 & 118.210 & 45 \\
\hline
\end{tabular}

Tabel 4.1. laat ons zien wat het netto burgerloon van een dienstplichtige is. ${ }^{5}$ Daarnaast bevat tabel 4.1. het percentage jongeren per jaarloonklasse, het cumulatieve aantal jongens in Nederland met een gelijke leeftijd en het absolute aantal dienstplichtigen per jaarloonklasse. ${ }^{6}$ Deze laatste kolom is berekend door het totaal aantal dienstplichtigen in 1988, 44.761, te vermenigvuldigen met het percentage jongeren in diezelfde jaarloonklasse. Dit is mogelijk omdat in Nederland de persoonlijke dienstplicht geldt, zonder dat daar veel vrijstellingen aan verbonden zijn. De kans om in dienst te moeten is voor ledere Nederlander vrijwel gelijk, waardoor iedere

\footnotetext{
3 Cort van der Linden (1887) in L.G.M. Stevens, Elementair belastingrecht, Dewenter, 1985, bla. 272. In Stevens zijn. nog 20 andere definities van het begrip belasting gegeven. Materieel komen zij allen mat elkaar ovareen, zoals hien werigegeven. 1

4Zie 0.a. L.G.M. Stevens, Elementair belastingrechi, Deventer, 1989, blz.14.

5 Cijfers A en B: Statistisch zakboek 1991, Centraal Bureau voor de Statistiek, blz 99. Cijfrers C en D: Jaaroverzicht dienstplichtgegevens 1988, Ministerie van Defensie. Alle gepresenteverde cijfers hebben betrekking op het jaar 1988. ${ }^{6}$ Hetcumulatieve aantal jongensi met een gelijke leeftijt is bepaald op basis wan het overzicht van de keturingsuitslag in 1988. In 1988 lieten 118.566 jongens zich keuren. Door afrondingewerschillen siluit hat totaal van kolom $C$ niet geheel aan bij het feitelijke keuringsaantal. Om met behulp wan kolom B kolom D op te maken is verondersteld dat iedere jaarklasse ongeweer èvengroot is qua jongens (ong. 118.000) en dat de gemiddelde leeftijd van do dienstplichtige 20 jaar is. Dit laatste is in overeenstemming met de werkelijkheid.
} 
Nederlandse bevolkingsgroep binnen het dienstplichtigenbestand vertegenwoordigd is. ${ }^{7}$

In 1988 bedroeg de gemiddelde netto wedde voor een dienstplichtige fl 12.000 ,op jaarbasis. De hoogte van de baalpremie is niet gemakkelijk in te schatten. Cooper stelt dat als de behoefte aan militairen stijgt, ceteris paribus, de krijgsmacht eigenlijk een hogere premie dient te bieden om de militairen vrijwillig binnen de muren van de kazerne te halen ${ }^{8}$ Hij veronderstelt hiermee een positief verband tussen de baalpremie, het benodigde aantal dienstplichtigen en het alternatieve burgerloon. Uit het onderzoek van Cooper blijkt verder dat de baalpremie op ongeveer $20 \%$ van het verschil tussen het burgerloon en de wedde kan worden geschat. ${ }^{9}$ Daar het technisch onmogelijk is de exacte hoogte van de baalpremie te bepalen, zijn de geschatte gegevens voor de Verenigde Staten overgenomen voor Nederland. ${ }^{10}$

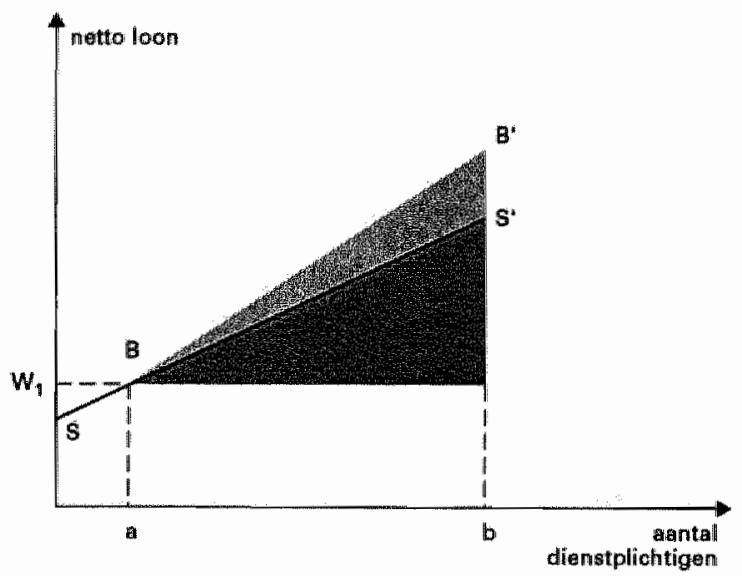

figuur 4. De dienstpliehtbelasting

In figuur 4.1. is $S S^{\prime}$ de grafische weergave van het burgerloon van dienstplichtigen, terwijl de "baalpremie" weergegeven wordt door de afstand tussen de $B B$-en $S S$ curve. $W_{1}$ is daarbij de wedde die de dienstplichtige ontvangt. De afstand $O b$ geeft de behoefte van de krijgsmacht aan dienstplichtigen weer.

Zou in Nederland het dienstplichtigenbestand volgens het "lowest-supply-price drafted-first (LSPDF)" principe gevuld worden, dan geeft het gearceerde gebied onder de $S S$-curve de dienstplichtbelasting weer. Onder normale omstandigheden (dus zonder dwang) zouden de personen met de laagste "opportunity costs" reeds bij de hoogte van de wedde die de lijn SS" weergeeft vrijwillig in dienst zijn gegaan en is er voor hen geen sprake van een "baalpremie". Nederland kent echter een loterijsysteem, waardoor iedereen voor de dienstplicht in aanmerking komt en niet alleen de mensen met de laagste "opportunity costs" en waardoor tevens de "baalpremie" een belang-

\footnotetext{
7 In paragraaf 3 wan dit hoofdstuk komt de verdeling van de dienstplichtlast uitgebreld aan de orde, on wordt de hier gebruikte veronderstelling werder uitgewerkt.

${ }^{8}$ Richard V.L. Cooper, Malitary manpower and the all-wolunteer force, Santa Monica 1977, blz. 70.

9 Idom, ble, $70-74$

$10 \mathrm{Navraag}$ biy de wakbonden van dienstplichtigen en eigen veldonderzoek bäj bezoeken aan kazernes duidt er op dat de $20 \%$ baalpremle voor Nederland een redelijke maatstaf is.
} 
rijke rol gaat spelen. De dienstplichtbelasting bestaat daarom uilt het totale gearceerde gedeelte onder de curve $B B^{\prime}$. De omvang van de dienstplichtbelasting in Nederland wordt verkregen door de sommatie van de dienstplichtbelasting van iedere dienstplichtige. Zo kent de groep uit klasse 5 in tabel 4.1. een gemiddeld netto jaarloon van II $16.250,-$, terwijl een dienstplichtige wit deze groep slechts fil $12.000,-$ ontvangt. De dienstplichtbelasting voor deze dienstplichtige bedraagt dan $(16.250-12.000) \times(1+$ $20 \% 11)=\mathrm{fl} \mathrm{5.100,-.} \mathrm{Wordt} \mathrm{deze} \mathrm{berekening} \mathrm{voor} \mathrm{iedere} \mathrm{dienstplichtige} \mathrm{toegepast,} \mathrm{dan}$ komen we voor de totale omvang van de dienstplichtbelasting in Nederland op een. bedrag van 360 miljoen gulden.

De hier gebruikte interpretatie van de dienstplichtbelasting kent echter een probleem. Zij maakt de impliciete, maar cruciale, veronderstelling dat de confiscatie van "economic rent" door de overheid geen belastingheffing betreft. Normaliter past de overheid geen dwang toe bij het vervullen van haar vacatures en laat de overheid het surplus dat gegenereerd wordt bij consumptie of produktie toekomen aan die persoon die daar ook recht op heeft. Juist door het toepassen van dwang incasseert de overheid deze extra "rents". Figuur 4.2. laat zien dat de krijgsmacht in de afwezigheid van de dienstplicht een concurrerende wedde gelijk aan de wedde $\left(W_{2}\right)$ moet bieden, wil zij voldoende vrijwilligers kunnen werven om de behoefte $\mathrm{Ob}$ te vullen. Het resultaat is dat de vrijwilligers een surplus ontvangen gelijk aan het verschil tussen de concurrerende wedde $W_{2}$ en hun eigen aanbodprijs. Het surplus is gelijk aan de "economic rents" die de overheid nu door het dienstplichtsysteem opstrijkt.

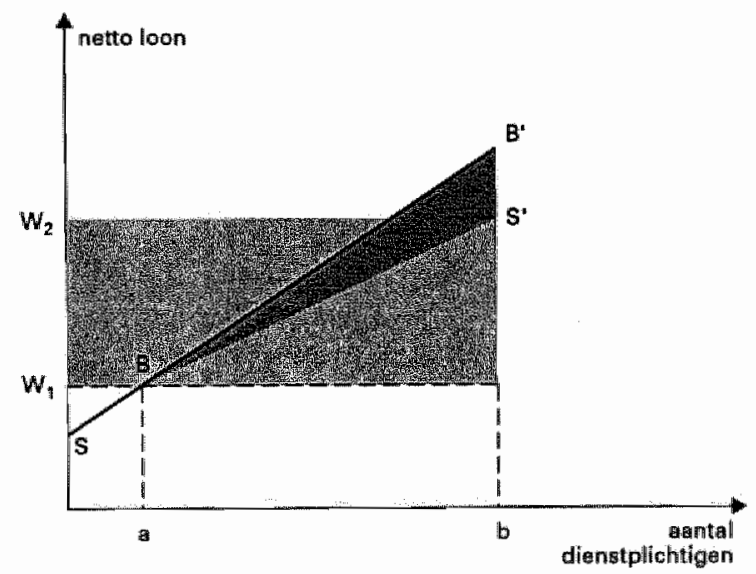

figuur 4.2 Die "bredle" dienstplichtbelasting

\section{Dit overziende stellen Sjaastad en Hansen: ${ }^{12}$}

"... [the] narrow definition of the conscription tax reflects an implicit assumption that the confiscation of economic rent does not constitute taxation. Conscription can be viewed as a means of coercion whereby the government reduces the budgetary cost of military manpower procurement, and only part of that

\footnotetext{
$11 \mathrm{De} 20 \%$ is de hoogte van de baalpremie.

12 Larry A. Sjaastad en Ronald N. Hansen, The comscription tax An empirical analysis", op cit., p. IV-1-2, IH Cooper, 1977 , blz 8.1-82
} 
reduction takes the [narrow] form of tax defined abiove, the remainder being rents foregone. A persuasive argument can be made however, that the tax should also include forgone rents. In procurement of manpower for civilian functions (i.e. the Post Office) or procurement of materials, the government abides by the ethical norm of our society that surpluses, be they generated in production or consumption, are properly the property of the person to whom they actually accrue. Whille it is true that these rents are not necessary to attract individuals to military service, it is also true that similar rents are in fact collected by the sellers of goods and services to the government in virtually all other cases. It is only in the case of certain military manpower procurement that coercion is systematically employed to reduce rents".

Rekening houdend met deze ruime definitie kan de dienstplichtbelasting gemeten worden door de grootste van 1) het verschil tussen het marktloon $\left(W_{2}\right)$ en de wedde $\left(W_{1}\right)$ of 2) het verschil tussen de aanbodprijs en de wedde. $W_{2}$ is groot fl $19.095_{r}-$, de wedde die minimaal geboden moet worden om 44.761 jongens vrijwillig in dienst te krijgen. ${ }^{13}$ In figuur 4.2. komt dit overeen met het gehele gearceerde gedeelte. Het belang van het onderscheid tussen de twee maatstaven van de dienstplichtbelasting is niet zozeer de omvang van de dienstplichtbelasting als wel het effect op de inkomensverdeling door de dienstplicht. De krappe, eerder beschreven definitie van de dienstplichtbelasting, erkent namelijk niet dat de individuen op het lager gelegen gedeelte van de aanbodcurve ook belast worden, omdat zij in de krijgsmacht ongeveer het zelfde verdienen als in de burgermaatschappij. Zij missen echter de "economic rents". De krappe definitie van de dienstplichtbelasting verhult daarmee tevens ongewenste sociale en publieke effecten van de militaire dienst in het algemeen. In geld uitgedrukt bedragen deze extra sociale kosten 90 miljoen gulden. De totale omvang van de dienstplichtbelasting is nu 450 miljoen gulden 14,10 duizend gulden per dienstplichtige.

\section{§4.2. De onderbroken loopbaan}

In de vorige paragraaf is de prijs van arbeid in de krijgsmacht nader bekeken. We hebben gezien dat de sociale kostprijs van arbeid in de krijgsmacht veel hoger ligt dan de werkelijke kostprijs, door het bestaan van de dienstplichtbelasting. De gevolgen voor de allocatie in de krijgsmacht en het aanbod van vrijwilligers die dit verschil tussen kostprijs en sociale kostprijs heeft, komen nader aan bod in hoofdstuk 5 en 6 . In deze paragraaf wordt een ander aspect van de dienstplicht besproken dat in verband kan worden gebracht met de dienstplichtbelasting. Tot nu hebben we de omvang van de dienstplicht besproken gedurende de periode van actieve dienst. Dienstplicht heeft echter ook nog een uitgesteld effect, welke hier het effect van de onderbroken loopbaan wordt genoemd. Dienstplichtigen komen een jaar later op de arbeidsmarkt dan hun leeftijdsgenoten die de dienstplicht niet hebben hoeven vervullen. $\mathrm{Zij}$ lopen een jaar vertraging op door de dienstplicht. Anderszijds kan de dienstplicht ook een leereffect hebben welke door werkgevers extra beloond wordt, waardoor de voormalige dienstplichtigen juist een voordeel in hun maatschappelijke loopbaan ondervinden.

\footnotetext{
13 Voor 44.761 goadgekeurde jongens zilin ongever 61.000 ongekeurde jongens nodig, daar het keuringspercentage $73 \%$ bedraagt. Het loon dat minnimaal geboden dient te worden on 61 . Co0 jongens vrijwillig in dienst te krijgen is vervolgens weer af te lezen witt tabel 4.1., kolom A en C, en bedraagt op jaarbasis $f 19.095$,-

${ }^{14}$ De onvang van de dieristplich tbelasting bestaat uit krappe definitie dienstplichthelasting: 300 miljoen, baalpromile: 60 miljoen en "economic tents": 90 miljoen.
} 
Onderzoek naar de loopbaaneffecten van de dienstplicht zijn voornamelijk afkomstig uit de Verenigde Staten van Amerika. Zo vonden Rosen en Taubman (1982) ${ }^{15}$, Swartz (1986) 16 en Crane en Wise (1987) ${ }^{17}$ dat Vietnam veteranen minder verdienden dan niet-veteranen, terwijl DeTray (1982) ${ }^{18}$ en Berger en Hirsch $(1983)^{19}$ juist enige positieve effecten vonden voor verschillende leeftijds- en scholingsgroepen tussen Vietnamveteranen en niet-veteranen. Onderzoekers van de Veterans Administration $(1981)^{20}$ vonden een algemeen positief effect voor de veteranen ten opzichte van de niet-veteranen. In alle genoemde onderzoeken speelde de oorlog in Vietnam een belangrijke rol bij de inkomensverschillen en bleek het moeilijk de gevolgen van de dienstplicht als een op zichzelf staand verschijnsel te ontdekken. Recent onderzoek door Joshua D. Angrist ${ }^{21}$ laat de scheiding tussen inkomensverschillen veroorzaakt door de dienstplicht en de oorlog in Vietnam wel zien. Angrist toont aan dat Vietnam-veteranen, in dienst gekomen volgens het loterijsysteem, 10 jaar na hun diensttijd gemiddeld $15 \%$ minder verdienen dan hun leeftijdgenoten die niet in dienst zijn geweest. Een verlies dat louter en alleen voortkomt uit het gemis van twee ervaringsjaren door de dienstplicht. ${ }^{22}$ Zouden de resultaten van Angrist ook voor Nederland maatgevend zijn, dan zou een diensttijd van 1 jaar tot een verschil in inkomen tussen veteranen en niet-veteranen van $7,5 \%$ moeten leiden.

Uitgedrukt in guldens betekent dit voor alle voormalige dienstplichtigen samen een extra inkomensverlies of dienstplichtbelasting van 927 miljoen gulden per jaar. ${ }^{23}$ Het probleem met deze uitkomst van het loopbaanverlies is dat deze gebaseerd is op gegevens uit de Verenigde Staten. Dit wil nog niet zeggen dat ze ook voor Nederland geldig zijn. In appendix 4.1. van dit hoofdstuk is geprobeerd de Nederlandse situatie op dit gebied te analyseren. Voorlopig zijn resultaten nog niet te verwachten daar het onderzoek technisch zeer moeilijk uitvoerbaar is.

Het CBS is in 1984 begonnen met het Sociaal Economisch Panelonderzoek. Aan de hand van dit onderzoek moet het in de toekomst wel mogelijk zijn resultaten te verkrijgen. Het CBS verwacht dat dit rond het jaar 2010 ook daadwerkelijk kan. ${ }^{24}$ Het Sociaal Economisch Panelonderzoek beslaat momenteel ongeveer 5.000 huishoudens,

\footnotetext{
${ }_{15}$ S. Rosen en P. Taubman, "Changes in Lifecycle Earnings: what do Socialsecurity Data show?", Journal of Human Sciences, zomer 1982.

16. Schwartz, "The relative Earnings Experience of Vietnam and Korean era Veterans"', Industrial and Labor" Relations Review, juli 1986.

${ }^{17}$ J.R. Crane en D.A. Wise, "Military Service and the Civilian Earnings of Youth" in D.A. Wise (ed), Public Sector Payrolls, Chicago, 1987.

18D. N. DeTray, "Veteran Status as a Screening Device" "American Economic Review, metart 1982.

${ }^{19}$ M.C. Berger en T. Hirsch, "The civilian Eamings Experience of Vietrain Era Veterairs" Journal of Human Rew sources, herifst 1983.

20Veterams Administration Reports and Statistic Service, Research mongraph 15: Education and Income Characteristies of Veterans, Marrch 1979, Washington, 1981.

21 joshua D. Angrist. Lifetime Earnings and the Vietnam Era Draft Lottery, Evidence from Social Administrativo Records American Economic Review, Vol. 80, juni 1990.

22 Angrist maakt voor zijn onderzoek gebruik van het nieuwe loterijsysteem dat in de VS gold tem wijde van het rinde van de Vietnam-oorlog. Het grote verschil met wroegere loterijsysternen is, dat deze slechts zeer weinig vrijstellingen kende en daarmee goed vergelijkbaar is met het systeem dat wij in Nederland kennen.

23 Verondersteld is een loonachterstand van dienshplichtigen van $7,5 \% 10$ jaar na hun diensttije, waarbil de leeftijd tijdens de dienstplicht op 20 jaar wordt bepaald. Het gemiddelde loon van een 30-jarige is f 26.800 , Gemiddeld loon van een veteraan is dan $\mathrm{A} 25.537$, (Mi). Gemiddeld loon wan een niet-veteraan is f 27.608, (N), Lasten loopbaanomderbmeking: (M-N) $\times 44.761=92,7$ miljoen per jaar per jaarklasse. Voor de totale lasten is weronder steld dat er 10 jaarklassen zijn, die allen in het heden de extra belasting van $7,5 \%$ ondervinden $(10 \times 92,7$ milloen $=927$ miljoen). Cijfers: Statistisch jaarboek 1991, CBS ble. 99.

24. Gesprekken op het Centraal Bureau woor de Statistiek, Heerlien, 7 oktober 1992 met dhr. Linden en dhr. Winkels: van de afideling Sociaal Economisch Panelonderzoak. Daar werd tevens bewestigd dat de onderzoeken in de Venenigde Staten vele decennia voor liggen op de onderzoeken in Nederland.
} 
waaronder 40 dienstplichtigen. Het onderzoek richt zich op velle economische aspecten van een huishouden, zoals inkomen, uitkering, de aankoop van duurzame consumptiegoederen enz. Dit onderzoek wordt ieder jaar twee maal herhaald, waarbij geprobeerd wordt zoveel mogelijk de zelfde huishoudens te enquêteren. Op de lange termijn wordt zo een life-time profiel verkregen. Het aantal dienstplichtigen in het onderzoek is voorlopig te gering om daar significante uitspraken over te doen.

\subsection{De verdeling van de dienstplichtbelasting}

In 1988 ging 39\% van de Nederlandse jongens in dienst. Figuur 4.3. laat zien dat dit in de twintigste eeuw geen uitzonderlijk percentage is geweest. Het percentage is vrij stabiel geweest rond de 35\%, met uitzondering van de jaren 1952-1960 toen het percentage steeg tot $55 \%$.

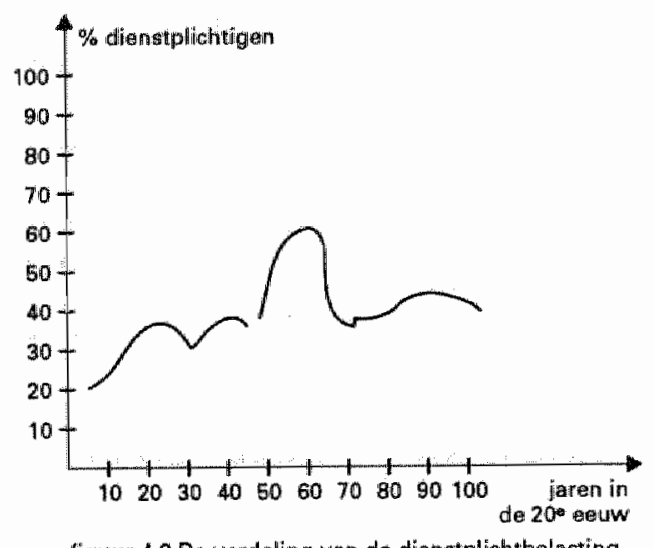

figum 4.3 Do verdating vam de diensiplichtbelasting

Vergelijken we de verdeling van de dienstplichtbelasting tussen generaties dan is deze verdeling er niet echt onrechtvaardiger op geworden. Intragenerationeel is de situatie anders. $39 \%$ van de jongens in Nederland of ongeveer $20 \%$ van alle jongeren betaalt gemiddeld een belasting van 10 duizend gulden, terwijl de overige $80 \%$ aan de betaling van de belasting ontsnapt. In deze paragraaf zullen we aan de hand van de verdelingsbeginselen van de Langen zien of de dienstplicht als belasting-in-natura nu rechtvaardig is of niet.

De Langen heeft aan de hand van empirisch onderzoek zes hoofdbeginselen opgetekend die in Nederland in onderling verband aan alle onderdelen van het belastingrecht ten grondslag liggen. ${ }^{25}$ Drie van deze beginselen zijn rechts- of verdelingsbeginselen, welke hierna besproken zullen worden. De overige drie doelmatigheidsbeginselen, het welvaartsbeginsel, het beginsel van de minste pijn en het beginsel van de maximale realisatie zullen in deze paragraaf niet aan de orde komen.

Het eerste verdelingsbeginsel is het draagkrachtbeginsel. Dit beginsel houdt in dat belasting kan worden geheven naar rato van de draagkracht van de belastingplichtigen. De draagkracht kan bepaald worden aan de hand van verschillende maatstaven, zoals inkomen, consumptie of vermogen. Ten grondslag aan het draagkracht-

${ }^{25}$ Zie L.G.M. Stevens, Elementair belastingrecht, Deventer, 1985, blz 3-5. 
beginsel ligt het gelijkheidsbeginsel. Dit houdt in dat personen met een zelfde inkomen een gelijk bedrag aan belasting moeten betallen. Wanneer zij evenwel een ongelijk inkomen hebben is ook hun draagkracht ongelijk en moet de te betalen belasting derhalve ook ongelijk zijn. Bij het bepalen van de mate wan ongelijkheid van belastingheffing speelt de leer van het evenredige genotsoffer een belangrijke rol. Volgens deze leer dient het belastingtarief zodanig te worden vastgesteld dat een ieder een everuredig genot van zijn inkomen moet opofferen. Willen we bereiken dat iedereen een gelijk percentage nuttigheid opoffert, dan zal dit betekenen dat iemand bij een toenemend inkomen relatief meer belasting moet betalen, daar het nut van eên extra gulden afneemt naarmate het inkomen toeneemt. Dit leidt dan tot een progressieve belastingtariefstructuur.

Het dienstplichtsysteem kent geen horizontale gelijkheid. Personen met eenzelfde achtergrond (jonge mannen) worden niet gelijk belast, omdat in de praktijk slechts $39 \%$ de dienstplicht vervult en zo de dienstplichtbelasting betalt. Ook wordt met de dienstplicht het verticale gelijkheidsbeginsel geschonden. Volgens de leer van het evenredige nutsoffer betalen hogere inkomens meer belasting dan lagere inkomens, terwijl bij de dienstplichtbelasting de situatie juist andersom is. De mensen met de laagste inkomens (jongeren) betalen een hoge belasting, terwijl de hoogste inkomens (ouderen) dit niet hoeven te doen. Uit dit alles kan geconcludeerd worden dat de dienstplicht volgens het draagkrachtbeginsel geen rechtvaardige belasting is.

Het tweede verdelingsbeginsel is het profijtbeginsel. Toepassing van het profijtbeginsel houdt in dat belasting wordt geheven naar de mate waarin het individu profijt heeft getrokken uit de door de overheid gefinancierde voorzieningen. Het profijt kan bestaan uit een waardestijging of een kostenbesparing. Daarom wordt het profijtbeginsel ook wel als het vergoedingsbeginsel aangemerkt. Dit vergoedingsbeginsel kent dan als varianten het profijtbeginsel en het schadevergoedingsbeginsel. Volgens het profijtbeginsel kunnen diegenen worden bellast die gebaat zijn met hetgeen door overheidsgeld tot stand is gebracht. Op grond van het schadevergoedingsbeginsel worden degenen belast die door hun gedragingen de overheid noodzaken tot het doen van extra uitgaven. Maar een dienstplichtige bezorgt geen schade aan de overheid, de overheid zorgt juist voor schade aan de dienstplichtige, zonder dat de overheid deze schade vergoedt. Het profijt dat een dienstplichtige van de dienstplicht ontvangt kan verwaarloosd worden. Dit hebben we in de vorige paragraaf reeds kunnen zien. Onderzoek van de Koninklijke Militaire Academie ${ }^{26}$ heeft daarnaast aangetoond dat een voormalige dienstplichtige geen streepje voor heeft op nietdienstplichtigen bij het bedingen van een baan in de burgermatschappij. Concluderend kunnen we bij het profijtbeginsel stellen dat de dienstplicht niet rechtvaardig is.

Het laatste verdelingsbeginsel is het beginsel van de bevoorrechte verkrijging. Belastingheffing op basis van het beginsel van de bevoorrechte verkrijging impliceert, dat een speciale belasting geheven kan worden indien de verkrijger bij de verkrijging van een bate in een bevoorrechte positie verkeert in vergelijking met anderen. Er moet sprake zijn van een buitenkansje. Doch bij de huidige vorm van de dienstplicht kunnen we niet echt spreken van een buitenkansje. Daarom is het beter hier te spreken van het beginsel van de moeizame verkrijging. Op grond van dit beginsel kunnen belastingverminderingen worden toegestaan aan degenen die zich bij de inkomensvorming extra inspanningen moeten getroosten. In de huidige

\footnotetext{
26: Smidt (et al): Een verloren jaar die relevantie van militaire dienstplicht voor de arbeidimarkt, in: Maatschappilj en krijgsmacht - Den Haag augustus 1992, nr 14, blz. 10-15.
} 
belastingwetgeving speelt het beginsel van moeizame verkrijging geen rol, maar zou een oplossing kunnen bieden de onrechtvaardigheid van het loopbaanverlies door de dienstplicht te ondervangen. Gedurende bepaalde tijd na het vervullen van de dienstplicht komt een belastingplichtige dan in aanmerking voor belastingverminderingen door gebruik te maken van een extra aftrekpost. Ook hier is de reeds eerder gemaakte conclusie zonder meer geldig: dienstplicht is onrechtvaardig. Eén element van de verdeling van de dienstplichtlast is hier nog niet onderzocht. Dat is de vraag of iedere groep in de Nederlandse samenleving ook daadwerkelijk evenveel kans heeft om in dienst te moeten. Siccama ${ }^{27}$ stelt zich de vraag wie dan wel voor de dienst opdraait. Hij oppert daarvoor vier hypothesen:

1. De kans dat men niet daadwerkelijk wordt ingelijfd neemt toe naarmate de opleiding (en het daarmee correlerende inkomen) van de vader en de jongeling zelf hoger $z$ inj $n$;

2. De kans dat men niet hoeft op te komen neemt toe naarmate men zich linkser op het partijpolitieke spectrum bevindt;

3. De waarschijnllijkheid dat men in dienst moet neemt toe als men vaker naar de kerk gaat (de meest operationele definitie wan het behoren tot een kerkelijke gezindte/geloof);

4. De kans dat men in dienst moet is kleiner als men in een grote stad (of in de Randstad) woont dan als men woonachtig is op het platteland (of buiten de Randstad).

Deze vier hypothesen vat Siccama samen tot de stelling dat het veel waarschijnlijker is dat de zoon van een godvruchtige Zeeuwse landarbeider in dienst gaat dan de zoon van een socialistische hoogleraar uit Amsterdam. Deze stelling is tevens onderzocht door de commissie-Meijer in het kader van haar opdracht de dienstplicht te onderzoeken. Zij komt tot de conclusie dat de hypothese-Siccama geen ondersteuning vindt in de praktijk. 28

Maar zelfs als het zo zou zijn, dan is het niet zo dat grote groepen in Nederland zich aan de dienstplicht kunnen onttrekken, zoals dat in de Verenigde Staten wel het geval was. Ook uit onderstaande tabel 4.2 . blijkt dat de verdeling van de dienstplicht tussen groepen redelijk rechtvaardig is. De tabel is gebaseerd op een vergelijking tussen de opleiding van dienstplichtigen en de opleiding van mensen die hun studie zojuist afgerond hebben en op zoek gaan naar een baan op de arbeidsmarkt. Wel zijn er enige verschillen waarneembaar, doch er kan zeker niet geconstateerd worden dat grote groepen niet in dienst hoeven en de persoonlijke dienstplicht op grote schaal ontweken wordt.

Tabel 4.2: Dienstplichtigen en schoolverlaters ${ }^{29}$.

$\begin{array}{lcc}\text { Schoolopleiding } & \text { Dienstplichtig in \% } & \text { Schoolverlaters in \% } \\ \text { LBO/Basisschool } & 12,25 & 22,33 \\ \text { MAVO } & 6,76 & 8,40 \\ \text { MBO } & 46,76 & 41,33 \\ \text { HAVO/VWO } & 10,84 & 10,07 \\ \text { HBO } & 16,90 & 9,46 \\ \text { WO } & 6,33 & 8,16\end{array}$

27 J.G. Siccama: Milhtaire dienstplicht, ondoelmatig en onrechtvaardig, in: Dienstplicht afschaffen of uitbreiden?, C. Homan en J.G. Sticcama (red), Clingendael, 1990.

28 Achtergrondbundel behorende bij het rapport "Naar dienstplicht nieuwe stijl" van de commissie dienstplicht. Onderdeel "dienstplichtigen over dienstplicht" door Dr. R.M.W. van Gelooven, bijlage 3, biz. 36.

29 Ciffers: SMK-VVDM onder zoek september 1991 en Statistisch jaarboek 1991, CBS, blz. 413 "Bij de berekening van het percentage schoolverlaters zijn mensen die zonder diploma de school werlaten naar redelijkeid ondergebracht in de onderliggende groep schoolverlaters. 


\section{§4.4. De inningskosten van de dienstplichtbelasting}

Iedere belasting moet geind worden, wil de overheid de bellastinggelden produktief kunnen aanwenden. Voor de inning van de belastingen heeft de overheid een groot apparaat ontwikkeld: de belastingdienst. Dienstplicht is ook een belasting en vanzelfsprekend zitten aan de inning van de dienstplichtbelasting ook vele kosten vast. Kosten die te maken hebben met de keuring, opleiding, huisvesting en kleding van de dienstplichtige, maar ook met de ontwijking en ontduiking van de dienstplicht.

Willen dienstplichtigen kunnen functioneren in de krijgsmacht, dan hebben zij daarvoor een opleiding nodig. In Nederland genieten de dienstplichtigen een opleiding van gemiddeld 2,5 maand om daarna 9,5 maand paraat gestationeerd te worden. Voor een leger met 36.000 parate dienstplichtigen zijn in totall 45.500 man nodig, omdat voortdurend 9.500 man in opleiding zijn. Zou de diensttijd uit 19 maanden paraat en 2,5 maand opleiding bestaan, dan zouden er slechts 4.750 man in opleiding zijn. De lengte van de diensttijd verhoudt zich dus omgekeerd evenredig met de hoeveelheid mensen in opleiding en de kosten van opleiding. Bij een verkorting van de diensttijd zal bij een gelijkblijvend aantal benodigde parate dienstplichtigen de verhouding produktieve/niet-produktieve tijd afnemen, zullen meer trainers uit parate functies in opleidingsfuncties moeten worden ingezet en zal minder ervaren personeel haar taak niet zo goed kunnen uitoefenen als ervaren personeel. Te grote "turnover rates" kunnen de totale defensiecapaciteit in gevaar brengen. Het opleiden van de dienstplichtigen kostte in 1991 ongeveer 500 miljoen gulden per jaar. ${ }^{30}$

De kosten van kleding en huisvesting van de dienstplichtigen bedragen 265 miljoen gulden en de kosten van de keuring 22 miljoen. ${ }^{31} \mathrm{Na}$ het maken van deze kosten zijin de dienstplichtigen produktief. De kosten van opleiding, kleding etc. zijn nog kwantificeerbaar, dit in tegenstelling tot de kosten die tot doel hebben de dienstplicht te ontwijken of te ontduiken. Zeker in de laatste jaren is het oneigenlijk beroep op de Wet Gewetensbezwaarden enorm toegenomen. Juridische adviesbureau's verdienen flink aan weigeryuppies. Ruwe schattingen wijzen in de richting van zo'n 2,5 miljoen gulden per jaar. ${ }^{32}$ Kosten die zonder meer voortkomen uit het bestaan van de dienstplicht.

De Wet Gewetensbezwaarden is een andere kostenpost die voortkomt uit het bestaan van de dienstplicht. Zonder de dienstplicht had het fenomeen gewetensbezwaarden niet bestaan. Per jaar is er een bedrag van ongeveer 25 miljoen gulden met deze Wet gemoeid.

Tenslotte is ook studieuitstel een vorm van ontwijkingsgedrag en zal matschappelijke kosten met zich meebrengen, indien het uitstel een structureel karakter gaat krijgen.

In paragraaf 4.1. hebben we gezien dat de opbrengst van de dienstplichtbelasting 450 miljoen gulden bedroeg. Als we daar de inningskosten van de belasting tegenoverstellen, moeten we concluderen dat dienstplicht niet alleen een aanzienlijke

\footnotetext{
30 Antwoord van het Ministerie van Defensie naar alanleiding van kamervragen. van. Mevr. wan Heemskerk (VVD). Tweede Kamer 1990-1991, 21.800X, nu. 39 .

31 Idem.

${ }^{32}$ Schatting gemaakt op basis van telefonische interviews met de juridische adviesburo's.
} 
belasting is, maar dat dienstplicht een extreem inefficiènte manier is om deze belasting te innen. Tegenover iedere gulden belastingopbrengst staat meer dan een gulden kosten om de belasting binnen te halen. Andere belastingen kennen relatief veel lagere inningskosten ${ }^{33}$, zelfs indien we de lasten van de belastingplichtigen daarbij optellen.

\section{\$4.5. Slotopmerkingen.}

De maatschappelijke kosten van de dienstplicht zijn aanzienlijk. Voor de jongeren betekent de dienstplicht een groot inkomensverlies. Deze belasting houdt niet op nadat het dienstverband afgesloten is, maar ijlt na door het verlies aan ervaring dat dienstplichtigen lijden door de dienstplicht.

Dienstplicht is een belasting, zonder dat deze belasting terug te vinden is in de nationale boekhouding. De collectieve lastendruk is in Nederland een belangrijke economische en politieke indicator. $\mathrm{Zj}$ is gedefinieerd als de som van de belastingdruk, premiedruk en de druk van de niet-belastingmiddelen. Bij de bepaling van de belastingdruk zijn alle directe en indirecte belastingen relevant die worden geheven door de rijksoverheid, de overige publiekrechtelijke lichamen, de publiekrechtelijke bedrijfsorganisaties en de internationale lichamen. De dienstplicht valt hier als belasting niet onder. De rede voor deze beslissing is dat de dienstplichtbelasting niet in de kas van de overheid vloeit zoals alle andere belastingen. Maar dit is niet in overeenstemming met de idee achter de collectieve lastendruk. Deze geeft juist aan wat de last voor de Nederlandse samenleving is ter financiering van onze collectieve voorzieningen. De samenleving bestaat naast de overheid ook uit bedrijven en consumenten, zoals de nationale rekeningen ons leren. De dienstplichtbelasting is een last voor de samenleving en dient dus te worden opgenomen in het cijfer van de collectieve lastendruk.

Dienstplicht is bovendien een onrechtvaardige belasting, omdat geen enkel verdelingsbeginsel in overeenstemming is met de verdeling van de dienstplichtbelasting. Wel is het zo, dat de dienstplichtbelasting vrij goed verdeeld is over de gehele bevol$\mathrm{king}$, doch als individuele last duidelijk voelbaar is bij slechts $20 \%$ van de jongeren, terwijl de overige $80 \%$ aan de dienstplichtbelasting ontsnapt.

\footnotetext{
33 Zie onder andere: M.A. Allers, Kosten van owerdrachten voor particulieren en hulshoudens, Onderzoeksmemorand um ni. 483 , Instituut voor economisch onderzoek, Faculteit der economische wetenschappen, Mjjksuniversiteit Groningen, Groningen, 1992.
} 
Appendix 4.1

Een beschrijving van een onderzoek naar de inkomensverschillen tussen dienstplichtigen en niet-dienstplichtigen na afloop van hun diensttijd.

Het doel van dit onderzoek is om de lange termijn inkomenseffecten van de militaire dienstplicht te meten. Om het onderzoek te kunnen tuitvoeren zijn een groot aantal gegevens nodig:

1. Een bestand van ongeveer 3000 mannen uit een bepaald geboortejaar.

2. Van al deze mannen moet bekend zijn of zij in militaire dienst zijn geweest en wanneer zij de dienstplicht hebben vervuld (lichtingsploeg).

3. Over een periode van 10 jaar dienen de inkomensgegevens van de 3.000 mannen bekend te zijn.

4. De schoolopleiding van de 3.000 mannen moet bekend zijn. Hiermee moet voorkomen worden dat de uitkomsten significant beinvloed worden door de verschillen in. initiële opleiding.

5. Deze gegevens worden ieder jaar gevraagd in het Sociaal Economisch Panelonderzoek van het CBS welke bescheiden gestart is in 1984.

\section{Werkwijze}

A) Ieder persoon krijgt een nummer. Daar wordt bij aangetekend wat zijn lichtingsploeg, opleiding en inkomsten gedurende de periode 1980-1990 zijn.

B) Met behulp van statistische analyse wordt uitgerekend wat gemiddelden, varianties, significanties enz. zijn voor diverse groepen.

C) Deze analyses kunnen worden uitgevoerd indien er voldoende cijfermateriaal aanwezig is. Zoals reeds in paragraaf 4.2 . is gememoreerd, kan het CBS pas rond het jaar 2010 misschien voldoen aan de benodigdheden voor deze studie. Het is dus op dit moment technisch niet mogelijk het onderzoek uit te voeren. 

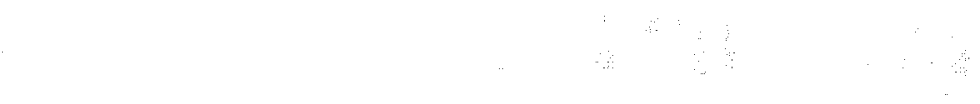

$\therefore$ 


\section{Dienstplicht en de allocatie van produktiefactoren}

"The larger point is that force structure itself should be a function of the costs of the specific imputs."

Richard V.L. Cooper in: Military Manpower and the All-Volunteer-Force, Santa Monica 1977, blz. 275.

\section{\$5.1. De theorie}

In hoofdstuk 2 hebben we gezien dat de aanwending van produktiemiddelen in de krijgsmacht een onttrekking van middelen aan de burgermaatschappij inhoudt. In de burgermaatschappij zijn deze middelen relatief schaars ten opzichte van de voorkomende behoeften. Derhalve kan alleen al vanuit deze invalshoek gesteld worden dat de produktiefactoren in de krijgsmacht ook schaars zijn. De "output" van de krijgsmacht mag dan buiten de markt om geschieden, voor wat betreft de "input" neemt zij wel degelijk deel aan het maatschappelijk ruilproces. Zowel op de arbeidsmarkt als op de kapitaalmarkt dient de krijgsmacht te voldoen aan de door de markt gestelde eisen.

Bij een door de internationale veiligheidssituatie bepaalde "defensieoutput" komt een efficiënte krijgsmacht neer op het minimaliseren van de kosten van haar "inputs", kapitaal en arbeid. In dit hoofdstuk is de internationale veiligheidssituatie zoals beschreven in de Defensienota 1991 als uitgangspunt genomen. In de krijgsmacht zijn de volgende produktiefactoren als specifieke "inputs" te beschouwen: kapitaal en arbeid, waarbij de produktiefactor arbeid weer onder te verdelen is in militairen, dienstplichtigen, beroepsmilitairen en burgers.

De micro-economische analyse leert ons dat als de kosten van specifieke produktiefactoren stijgen ten opzichte van de kosten van de alternatieve factoren in het produktieproces, produktiefactoren herverdeeld moeten worden door de dure "inputs" te vervangen door minder dure "inputs". Dit principe geldt ook voor de krijgsmacht en betekent dat de structuur van de krijgsmacht zelf een functie dient te zijn van de kosten van de specifieke produktiefactoren, gegeven de benodigde gevechtskracht zoals voortvloeit uit de Defensienota 1991.

De dienstplicht zorgt voor een verstoring van de allocatie in de krijgsmacht. Dit heeft twee oorzaken. Enerzijds verdienen dienstplichtigen $58 \%$ van het salaris van een beroepsmilitair met dezelfde rang. Dit betekent dat er sprake is van "goedkope arbeid". Anderzijds betekent de gedwongen deelname van dienstplichtigen in de krijgsmacht dat arbeid voor de krijgsmacht niet meer schaars is, waardoor militaire arbeid een "gratis" karakter krijgt. 
De krijgsmacht verliest een informatiefactor, omdat dle kosten van arbeid niet meer door de markt bepaald worden maar door de wetgever. Dit verlies is niet absoluut indien de krijgsmacht bij haar beslissingen de maatschappelijke kosten van de dienstplicht voor ogen houdt en niet slechts de budgettaire kosten. Zo zal het efficientieverlies door de diensitplicht beperkt blijven, indien de wedde voor dienstplichtigen niet afwijkt van het loon dat ze elders in de maatschappij zouden hebben verdiend en vergezeld gaat van het besef dat dienstplichtigen niet "gratis" zijn.

In de praktijk is dit echter anders. Dienstplichtigen krijgen een loon dat ver onder het marktloon ligt en de krijgsmacht toont een grote behoefte aan dienstplichtigen.1 Het gevolg voor de verdeling tussen kapitaal en arbeid in de krijgsmacht is dan ook dat in deze sector veel meer arbeid wordt gebruikt in verhouding tot kapitaal vergeleken met kapitaal-arbeid verhoudingen in de burgermaatschappij. In vredestijd uit dit zich ondermeer in verveling. Dienstplicht zorgt er voor dat de krijgsmacht veel mensen, veel militairen en veel onervaren mensen in dienst heeft. Dit verandert zodra militairen duur en schaars worden.

Modelmatig is het bovenstaande als volgt weer te geven.2

De technologische relatie tussen "inputs" (kapitaal, arbeid, militairen, beroepsmilitairen, dienstplichtigen en burgers) en "output" (gevechtskracht) wordt bepaald door de produktiefunctie:

1) $Q=f\left(x_{1}, x_{2}\right)$

$Q$ is gelijk aan de benodigde gevechtskracht.

$x_{1}$ is gelijk is aan de eerste "input".

$x_{2}$ is gelijk is aan de tweede "input".

De kosten van deze "inputs" worden bepaald door de kostenfunctie. In ons geval is deze":

2) $C=p_{1} x_{1}+p_{2} x_{2}$

$C$ is gelijk aan de totale kosten van de "inputs".

De verschillende $p$ 's geven de prijs van iedere specifieke "input" weer.

Een optimale allocatie van "inputfactoren" $\mathrm{kan}$ vervolgens worden verkregen door vergellijking 1 te maximaliseren onder de budgetvoorwaarde volgens vergelijking 2 of de minimalisatie van vergelijking 2 onder de voorwaarde van de benodigde gevechtskracht uit vergelijking 1 . Een noodzakelijke voorwaarde voor een optimum is dat de verhouding marginaal produkt/prijs voor ledere "input" gelijk is:"

3) $M x_{1} / p_{1}=M x_{2} / p_{2}$

$M x_{1}$ is gelijk aan het marginaal produkt van "input" 1 enz.

Indien we voor "input" 1 arbeid $(L)$ nemen en voor "input" 2 kapitaal $(K)$ zegt vergelijking 3 dat de verhouding tussen het marginaal produkt van arbeid en het marginal

\footnotetext{
1 Met andere woorden door het bestaan van de dienstplichtbelasting ligt de sociale kostprijs van dienstplichtigen
ver boven de werkelijke kostprijs.

2 Zil voor de algemene theoretische achtergrond: A. Koutsoylannis, Modem Microesconomics, London, 1975.
} 
produkt van kapitaal (de "technical rate of substitution") gelijk moet zijn aan de verhouding tussen de prijs van arbeid en de prijs van kapitaal:

4) $M x L / M x K=w / r$

$M x L$ is het marginaal produkt van arbeid.

$M x K$ is het marginaal produkt van kapital.

$w$ is het loon of de prijs van arbeid.

$r$ is rente of de prijs van kapital.

De marginale produkten van arbeid en kapitaal zijn positieve, maar afnemende functies van de hoeveelheden arbeid en kapitaal. Vergelijking 4 impliceert tevens dat indien de verhouding $w / r$ verandert, de verhouding $K / L$ ook verandert. Indien de lonen relatief stijgen ten opzichte van de kosten van kapitaal zal de hoeveelheid kapitaal $(K)$ toenemen ten opzichte van de hoeveelheid arbeid $(L)$.

Het hier gepresenteerde model vormt de basis voor onderzoek naar de allocatie van de verschillende "inputfactoren" in de krijgsmacht. Het model laat zien dat:

a) De gevechtskracht direct gerelateerd is aan de gebruikte "inputs", zodat doelmatig management bereikt wordt door de juiste keuzecombinaties van deze "inputs".

b) De indeling van de inputs in brede categorieën, zoals kapitaal, arbeid, millitairen, beroepsmilitairen, dienstplichtigen en burgers, een geschikte methode is om alternatieven ten aanzien van personeel en personeelskosten te onderzoeken.

c) De optimale allocatie van militaire middelen een functie is van de relatieve kosten van de "inputfactoren".

Met behulp van de hier beschreven methode zullen in het vervolg van dit hoofdstuk de volgende verschijnselen worden onderzocht: verveling, de verhouding kapitaalarbeid, de verhouding burger-militair en de verhouding onervaren-ervaren werknemers binnen de krijgsmacht.

\section{\$5.2. Verveling}

Verveling is een structureel verschijnsel in de krijgsmacht. Verveling ontstaat door de dienstplicht en betreft het in arbeidstijd doden van de tijd met niets doen. ${ }^{3}$ Dienstplicht zorgt voor een verplichte deelname aan het arbeidsproces binnen de krijgsmacht, waarbij het voor dienstplichtigen onmogelijk is om ontslag te nemen. Daar de personeelsvoorziening wettelijk geregeld is, bestaat er geen prikkel woor de werkgever aan de wensen van zijn werknemers tegemoet te komen. Lastige werknemers kunnen zonder veel problemen vervangen worden.

Verveling komt voort uit de plicht van de dienst en zal pas kunnen verdwijnen met de afschaffing van de plicht of met de mogelijkheid voor dienstplichtigen om zelf ontslag te nemen. Zelfs indien dienstplichtigen een beroepswedde zouden ontvangen, dan nog blijft de vervelling bestaan.

De omvang van de verveling hangt af van de kosten van arbeid. Zo is te verwachten dat de omvang van de verveling bij een beroepswedde minder zal zijn, dan bij een wedde van $58 \%$ van de beroepswedde, zoals we nu kennen. Dit komt omdat bij een hogere prijs van arbeid de vraag naar arbeid lager is en er minder mensen zijn die zïch vervelen.

${ }^{3}$ In deze paragraaf wordt geen onderscheid gemaakt tugsen ledigheid en verveling, zoals dit binnen het Ministurie van Defensie gewoon is, daar er in economisch opzicht geen onderscheid is tussen de twee begrippen. 
Er zijn twee principiële redenen om te veronderstellen waarom de vraag naar militaire arbeid op lange termijn een dalende functie is van de personeelskosten. Enerzijds werkt hier het substitutieeffect, omdlat arbeid ingeruild zal worden voor kapitaal indien arbeid duurder wordt. Anderzijds zorgt het inkomenseffect ook voor een vermindering van de hoeveelheid arbeid, omdat om minder defensie gevraagd zal worden als de budgettaire kosten stijgen als gevolg van gestegen personeelslasten.

De onvang van de verveling heeft dus te maken met het feit dat de krijgsmacht te veel of te weinig personeel in dienst neemt ten opzicht van het sociale optimum, zoals dit weergegeven is in figuur 5.1. door het snijpunt van vraag-en aanbodcurve in punt a. Dienstplichtigen krijgen een wedde welke lager is dan het marktloon, zodat we kunnen verwachten dat de krijgsmacht meer arbeid zal vragen, dan in het geval van marktevenwicht.

Zouden dienstplichtigen duur en schaars zijn geweest, dan kan aan de hand van het substitutieeffect worden verwacht dat zij vervangen worden door kapitaal. Juist niet door tanks, maar door oefentijd (human capital), verbeterde tanks en andere wapensystemen, bedrijfskantines en een betere opleidling. Ook zal er substitutie van millitaire arbeid door burgerarbeid plaatsvinden. Bij marktwerking is verspilling van arbeid kostbaar en dient dan ook voorkomen te worden. Bovendien hebben we dan nog niet eens gesproken over de negatieve effecten van de verveling op de arbeidssatisfactie van de werknemers. Door de negatieve effecten van de verveling bestaat voortdurend de dreiging dat de krijgsmacht leeg zal lopen.4

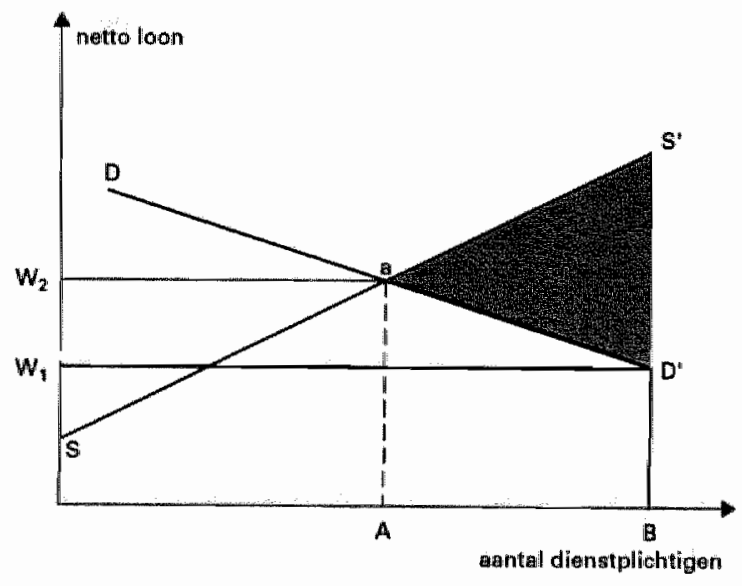

figuur 5.11 Vorveling

In Nederland zegt $75 \%$ van de dienstplichtigen zich in arbeidstijd meer dan 2 uur per dag te vervelen. 5 Gemiddeld bedraagt de verveling $25 \%$ van de arbeidstijd. Indien de verveling $\operatorname{van} 25 \%$ van de arbeidstijd als proxy wordt genomen voor de ondoelmatigheid in de krijgsmacht, zou een efficiënt werkend leger niet 44.761 soldaten (OB, figuur 5.1.) nodig hebben, maar slechts 33.570 (OA). Daar hoort dan wel

\footnotetext{
4 Zie ook hoofdstuk 6, paragiraaf 1 .

5 A VNM-onderzoek: Verveling in dienst, Utrecht 1989.
} 
een marktloon van 17.684 gulden netto $\left(W_{2}\right)$ op jaarbasis bij in plaats van een wedde van 12.000 gulden netto $\left(W_{1}\right) \cdot{ }^{6}$

De omvang van de verveling is gearceerd weergegeven in figuur 5.1. en zou 40,5 miljoen gulden bedragen indien het dienstplichtigenbestand volgens het LSPDF-principe gevuld zou worden. ${ }^{7}$ In Nederland kennen we echter de persoonlijke dienstplicht waatdoor de omvang van de verveling veel hoger uitvalt. Een schatting levert het bedrag van ongeveer 188 miljoen gulden op. Deze schatting wordt gemaakt door de oppervlakte van de viifhoek OSaD'B af te trekken van de oppervlakte van het gehele gebied onder de SS'- curve.

\section{§5.3. Kapitaal-arbeid substitutie}

In de vorige paragraaf hebben we reeds kunnen vernemen dat de vraag naar kapitaal zal stijgen, indien de dienstplicht wordt afgeschaft en militairen duur en schaars worden. Als gevolg van de dienstplicht kan de kapitaal-arbeidverhouding binnen de krijgsmacht lager zijn dan verwacht zou kunnen worden, indien de markt haar wil had kunnen opleggen. De substitutie tussen arbeid en kapitaal zal voornamelijk mogelijk zijn in die onderdelen van de krijgsmacht, die grote gelijkenis vertonen met sectoren in de burgermaatschappij.

De vergelijking met de burgermaatschappij kan hier dus een goed inzicht geven in de substitutiemogelijkheden. Dit is zeker het geval indien we ons voor ogen houden dat $75 \%$ van het personeel binnen de krijgsmacht werkt op een arbeidsplaats welke goed vergelijkbaar is met een arbeidsplaats in de burgermaatschappij. Deze $75 \%$ komt voort uit de 'teeth-to-tail'-ratio, die ongeveer $68 \%$ staart(burger)functies kent en het gegeven dat binnen de gevechtsfuncties een groot aantal logistieke functies is te onderscheiden die eender is aan een arbeidsplaats in de burgermaatschappij.

Belangrijk is dat de vergelijking geschiedt op basis van bestaande technologie. Zo zal kapitaal-arbeid substitutie binnen de gevechtsfuncties in de krijgsmacht zeker mogelijk zijn, maar zal dit ook om geavanceerde nieuwe technologie vragen. Nieuwe technologie die in de ondersteunende onderdelen minder noodzakelijk is, omdat zij in de burgermaatschappij veelal reeds bestaat.

Een voorbeeld uit de Nederlandse praktijk betreft het wachtlopen, c.q. de bewaking van de Nederlandse kazernes. Bewaking is eén van de hoofdtaken van de krijgsmacht. Bij bewaking wordt voornamelijk vertrouwd op de mens. Deze wordt in de materiële sfeer ondersteund door een portofoon, een wapen en het hek rond de kazerne. Dat de bewaking voornamelijk wordt uitgeoefend door mensen, heeft te maken met het kostenaspect dat er aan vast zit. Het meeste werk wordt uitgeoefend door de soldaten, die als dienstplichtigen zeer goedkoop zijn. Ten eerste omdat de wacht slechts gedeeltelijk in tijd gecompenseerd wordt en ten tweede omdat de compensatietijd goedkoop is, daar dienstplichtigen slechts een wedde krijgen welke ver onder het marktloon ligt. De mogelijkheid om de compensatietijd op te nemen wordt slechts dan gegeven als er werkelijk helemaal niets meer te doen is en de dienstplichtige zich flink verveelt.

\footnotetext{
6 Voor 33.570 jongens zijn bij een keuringspercentage van $73 \% 45.987$ jongens nodig. Het loon dat daw bifip zijn minst geboden dient te wordien is fil 17.684 netto per jaar. Zie voor die berekeningen appendix 5.1.

7 Verveling "Lowest-Supply-Price-Drafted-First (LSPDF) principe" en kosten werveling in Nederland; zie appendix 5.1. bij dit hoofdstulk.
} 
Zou arbeid duurder zijn geweest, beroepswedde voor dienstplichtigen of een particuliere bewakingsdienst, dan zou de dure arbeid automatisch worden vervangen door kapitaal. Hierbij dient met name gedacht te worden aan alarminstallaties en videocircuits. In hoeverre de bewaking door mensen vervangen wordt door bewaking door kapitaal hangt af van de marginale kosten van arbeid en kapitaal. Dure arbeid maakt kapitaal immers goedkoper.

De voorbeelden over verveling en wachtlopen spreken woor zich, doch het is de wraag of de stelling dat in de krijgsmacht de kapitaal-arbeid verhoudingen lager liggen dan in de burgermatschappij algemeen geldig is. Dit zal moeten blijken uit empirisch onderzoek van de kapitaal-arbeid verhoudingen binnen de krijgsmacht in vergelijking met dezelfde verhouding in de burgermaatschappij.

Uit onderzoek uit de Verenigde Staten blijkt dat er een duidelijk verschil bestaat tussen beide kapitaal-arbeid verhoudingen ${ }^{8}$. Daar bleek dat in de twintig jaren na de Tweede Wereldoorlog iedere $1 \%$ verandering in de loon-kapitaalkostentatio in de burgermaatschappij resulteerde in een $1,4 \%$ verandering in de verhouding kapitaalarbeid, ondanks het feit dat de burgermaatschappij in zijn geheel dienstengerichter was geworden. In de krijgsmacht bleek dat in de zelfde periode de stijging van ongeveer $40 \%$ in de loon-kapitaalkostenverhouding begelleid werd door een stijging van $1 \%$ in de verhouding kapitaal-arbeid. Iedere $1 \%$ verandering in de loon-kapitaalkostenratio resulteerde dus in een verandering van $0,025 \%$ in de verhouding kapitaalarbeid.

Een analyse voor Nederland kan het onderzoek uit de Verenigde Staten niet steunen. Dit komt voornamelijk voort uit het gebrek aan goede cijfers. Uit de periode 1972-1990 blijkt dat de krijgsmacht wel kapitaalintensiever is geworden, maar een onderscheid tussen investeringen en kapitaalgebruik in de gevechtseenheden en ondersteunende eenheden is zeer moeilijk te maken. Vooralsnog blijven de conclusies voor Nederland gelden op basis van globale waameming. ${ }^{9}$ De empirie in Nederland moet nog ontwikkeld worden.

Concluderend kunnen we stellen dat naarmate de werkzaamheden binnen de krijgsmacht goed vergelijkbaar zijn met werkzaamheden in de burgermaatschappij substitutie van arbeid door kapitaal zeker tot de mogelijkheden zal behoren. Uit de theorie en Amerikaanse empirie blijkt dat het mogelijk is voordeel te behalen uit de vervanging van arbeid door kapitaal.

In de praktijk kan dit echter nogal tegen wallen. Dit komt omdat de onderdelen in de krijgsmacht waar in termen wan substitutie de grootste voordelen te behalen zijn valk weinig aandlacht krijgen van de generale staven en het parlement. Zjj vinden de grote uitgaven in de gevechtsonderdelen belangrijk, terwijl juist in de overige niet-gevechtsonderdelen de meeste winst te behalen is. Daarnaast is van belang dat kapitaaluitgaven pas op langere termijn rendabel blijken te zijn, terwijl de generale staven en politici zich vaak fixeren op de kapitaaluitgaven op korte termijn zonder de lange termijn rentabiliteit onder ogen te zien.

De analyse in deze paragraaf heeft laten zien dat door kapital te substitueren voor arbeid op lange termijn naar alle waarschijnlijkheid met een lager budget kan worden volstaan dan nu het geval is. Of in andere woorden, lange termijn besparingen kunnen worden bereikt door de herallocatie van middelen, in plaats van het simpel schrappen in de sterkte van de gevechtskracht. Een herallocatie die noodzakelijk

\footnotetext{
8.Richard V.L. Cooper, Military Manpower and the All-Volunteer force, Santa Monica, 1977, blz. 286.

9 Dezo globale waarneming wordt ondersteund door subjoctieve visuele waarmemingen opgedaan tijdens het vervullen wan de dienstplicht.
} 
is bij het afschaffen van de dienstplicht. Daar dient wel bij opgemerkt te worden dat zulke herallocaties op korte termijn waarschijnlijk zullen leiden tot extra uitgaven, omdat investeringen op korte termijn nu eenmaal geld kosten.

\section{\$5.4. Militairen en burgers ${ }^{10}$}

Binnen de krijgsmacht werken naast militairen ook burgers. Burgers worden binnen de krijgsmacht gebruikt om functies te vervullen die niet direct een meerwaarde geven aan de gevechtskracht, maar toch zeker wel indirect. Militairen behoren op gevechtsfuncties te zitten, omdat daar een geweldselement aan gekoppeld is.

Tabel 5.1. geeft een overzicht van het aantal gevechtsfuncties voortvloeiend uit de Defensienota 1991. De gevechtsfuncties binnen de landmacht betreffen "het Eerste Legerkorps", binnen de luchtmacht "de vliegers van de F-16 transportvliegtuigen en helicopters en de functies voor het luchtafweergeschut" en voor de marine "de mariniers en het personeel op de schepen". De functies die nodig zijn om het mobilisabele deel van de krijgsmacht te organiseren en te leiden en de aflossing bij de marine zijn in tabel 5.1. meegenomen. ${ }^{11}$

Tabel 5.1. Aantal gevechtsfuncties per onderdeel

\begin{tabular}{|c|c|}
\hline Onderdeel & Gevechtsfuncties \\
\hline Landmacht & 26.500 \\
\hline Marine & 6.500 \\
\hline Luchtmacht & 2.000 \\
\hline Marechaussee & 3.000 \\
\hline In opleiding & 1.500 \\
\hline Totaal & 39.500 \\
\hline
\end{tabular}

In 1992 kende Nederland ongeveer 90.000 militairen. Door de inkrimping van de krijgsmacht, zoals is voorgesteld in de Defensienota 1991, zal een deel verdwijnen, maar dan nog blijft de vraag waarom de Nederlandse krijgsmacht zoveel militairen kent, terwijl er veel minder gevechtsfuncties ziji. ${ }^{12}$

Een antwoord kan gelegen zijn in de kosten van militaire en burgerarbeid. Indien een militair goedkoper is dan een burger is het voordeliger een militair een bepaalde functie te laten vervullen dan een burger en omgekeerd natuurlijk. Bij de vergelijking burger-militair is het noodzakelijk te kijken naar de kostenverhouding van deze soorten arbeid.

\footnotetext{
10 Deze paragraalf is ondermeer gebaseend op: M. Binkin, The Military Pay Muddle, The Broolkings Institution; Washington, D.C. 1975; M. Binkin, H. Kanter en R.H. Clark, Shaping the Dafremse Civilian Work Force, The Brookings Institution, Washington, D.C., 1978 en Stichting Maatschappij en Krijgsmacht, De prijis van defensie, Dern Haag, 1983.

11 Zie kamerw raag 207 en 211 Twede Kamer, vergaderjaar 19901991, 21991 , nr.8. De aantallen gewechtsfuncties voor de marine en de luchtmacht zijn geschat aan de hand van de Defensienota 1991. Hat aantal mariniers is gesteld op 3.000 en voor de scheepsbemaning (inciusief aflossing geldt een schip-wal ratio van 3:7. De2e ratio is teen ervaringsgetal uit de Verenigde Staten. De overige cilfer's zijn gebalseerd op de Defensienota 1991. De hier gebruikte schattingen zijn woorgelegd aan diverse exberne deskundigen op defensieterrein. Ook zij weten niet de exacte aantallen, maar kunnen zich in de hier gebruilkte schattingen vinden. De onderbouwing van het aantal gevechtsfuncties in opleiding van 1.500 wordt in 9.6 .6 , gegeven.

12 Het aantal militairen dient in 1995 te: verminderen bot 86.696 op een totaal van 107.573 werknemeris. Bron: Defensienota 1991.
} 
Een overschot aan militairen is te verklaren indien de gemiddelde kosten van een militair lager zijn dan de gemiddelde kosten van een burger. Het grote probleem bij het vergelijken van de kosten van burgers en militairen is de aanwezigheid van grote bedragen non-salariskosten bij de militairen, zoals training, kleding en de kosten van pensionering en vervroegde uittreding. Teneinde de gemiddelde kosten voor iedere groep te kuninen meten dienen de budgettaire kosten voor ledere groep gedeeld te worden door het aantal personer dat tot iedere groep behoort: Deze methode geeft een aardig inzicht in de kosten, maar is niet geheel ideaal daar de kosten van training van de militairen en burgers niet goed tot uitdrukking komen.

Tabel 5.2. geeft inzicht in de gemiddelde kosten van de verschillende werknemers binnen de krijgsmacht op basis van de cijfers van de Defensiebegroting 1992. Hiervoor is gebruik gemaakt van de omschrijvingen onder 01, 02 en 03 (personele kosten) van ieder hoofdstuk van de Defensiebegroting, voor 5 soorten groepen werknemers: burgers, dienstplichtilge militairen, beroepsmilitairen, militairen (dienstplichtigen + beroeps) en militairen $(+)$. De laatste categorie geeft weer wat de kosten van militairen zouden zijn, indien rekening zou worden gehouden met de maatschappelijke kosten van de dienstplicht door de dienstplichtigen een beroepswedde te geven. Momenteel ontvangen ze $58 \%$ van de beroepswedde. Onder de kosten in natura vallen zaken als reiskosten, kledingkosten etc. Zaken die geen beloningscomponent kennen.

Tabel 5.2.: Gemiddelde kosten werknemers krijgsmacht $\mathrm{t}^{13}$

$\begin{array}{llllrl}\text { Gemiddelde kos- } & \begin{array}{l}x 1 \\ \text { Aantal }\end{array} & \begin{array}{l}x f 1,- \\ \text { Loonkosten }\end{array} & \begin{array}{l}x f l,- \\ \text { Pensioen, } \\ \text { wachtgeld }\end{array} & \begin{array}{l}x f 1,- \\ \text { Natura }\end{array} & \begin{array}{l}x f 1,1^{-} \\ \text {Totaal }\end{array} \\ \text { Burgers } & 23.177 & 58.700 & 1.872 & 5.276 & 65.848 \\ \text { Dienstplichtigen } & 37.965 & 19.177 & 5.789 & 6.613 & 31.579 \\ \text { Beroeps } & 51.651 & 59.949 & 25.126 & 10.512 & 95.587 \\ \text { Militairen } & 89.616 & 42.930 & 16.934 & 8.866 & 68.730 \\ \text { Militairen (t) } & 89.616 & 48.997 & 16.934 & 8.866 & 74.797\end{array}$

Uit de tabel kan geconcludeerd worden dat het kostenverschil tussen burgers en militairen slechts gering is (ong $f 3.000,-)$. De huidige personeelsbezetting binnen defensie is met enige goede wil zeker te verklaren op basis van de huidige kostenverhoudingen.

De oorzaak van de huidige kostenverhoudingen is ook in de tabel te vinden: dienstplicht. Door de dienstplicht zijn de gemiddelde kosten van militaire arbeid lager dan dat zij geweest zouden zijn in het geval van een vrijwilligersleger. De dienstplicht verhult de kosten van militairen. Zouden dienstplichtigen een beroepswedde ontvangen, dan zullen militairen vervangen moeten worden door burgers.

Dit wordt nog des te duidelijker, indien we beseffen dat de trainingskosten van militairen veel hoger liggen dan de trainingskosten van burgerpersoneel. Militairen worden intern opgeleid, terwijl burgers hun opleiding genieten in het reguliere civiele opleidingscircuit.

Ook is het belangrijk te constateren dat door het benutten van de substitutiemogelijkheden kostenreducties te bewerkstelligen zijn zonder dat deze kostenreducties gepaard gaan met een vermindering van de totale gevechtskracht. Substitutie van mi-

13 Tabel 5.2. is gebaseerd op de Defensiabegroting 1992. 
litairen door burgers kan dus veel geld opleveren, maar we dienen wel te beseffen dat het kostenaspect secundair is an het feit of een militair wel door een burger vervangen kan worden.

Primair is de vraag of een functie een geweldskarakter met zich meebrengt. Militairen dienen de gewelldsfuncties of gevechtsfuncties te bezetten en burgers de niet-gevechtsfuncties, indien burgers goedkoper zijn dan militairen. Hiervoor is gebleken dat burgers inderdaad goedkoper zijn en dat de vervanging van militairen door burgers op de niet-gevechtsfuncties plaats moet vinden, willen we een efficiènte uitvoeringsorganisatie blijven houden.

Bij het onderscheid tussen burgers en militairen zijn de gewelds- en kostenaspecten de enige geldige criteria. Deze criteria zijn objectief van karakter en brengen weinig discussie met zich mee. Dit in tegenstelling tot criteria als traditie en ambtelijke regeling ${ }^{14}$ welke een subjectieve oorsprong hebben en daardoor niet geschikt zijn als afbakeningsinstrument tussen functies voor burgers en functies voor militairen.

De substitutie tussen burgers en militairen is bij de beoordeling van de dienstplicht van eminent belang. Door het bestaan van de dienstplicht zal de vraag naar de dienstplichtigen in beginsel "oneindig" groot zijn. Dit verklaart tevens waarom er zoveel militairen aanwezig zijn in de krijgsmacht. Afschaffing van de dienstplicht maakt militairen schaars en zo blijkt uit deze paragraaf ook duur. Het strikte onderscheil tussen gevechtsfuncties en niet-gevechtsfuncties is daarom des te belangrijker, omdat hieruit de werkelijke behoefte aan militairen voortvloeit. Dat burgers ook nog eens goedkoper zijn dan militairen is dan eigenlijk van secundair belang in een dienstplichtdiscussie. In een doelmatige krijgsmacht had de substitutie van burgers voor militairen eigenlijk altijd al moeten gebeuren. Bovendien versterkt een groter aantal burgers de vermaatschappelijking van de krijgsmacht. ${ }^{15}$

In de praktijk kent de burger-militair substitutie een aantal problemen. Ervaringen uit de Verenigde Staten leren ons dat de burger-militair-substitutie veel sympathie ondervindt, maar dat de substitutie naar de achtergrond verdwijnt indien de krijgsmacht er in slaagt voldoende vrijwilligers aan te trekken om aan de behoefte aan militairen te voldoen zonder dat de behoefte aan militairen tot een minimum is terug gebracht. In zo'n situatie is het probleem van de dienstplicht wel opgelost, maar is zeker geen doelmatige krijgsmacht gecreëerd. Charles Moskos constateert dat een vrijwilligersleger zeker niet goedkoper is dan een dienstplichtigenleger. ${ }^{16} \mathrm{Hij} \mathrm{komt} \mathrm{tot}$ deze conclusie na bestudering van de kosten van de Amerikaanse krijgsmacht, waarbij vooral een explosie in de kosten van pensionering en vervroegde uittreding waar te nemen is. Wat Moskos echter vergeet is dat de kostenverhoging niet het gevolg is van de afschaffing van de dienstplicht, maar van onvoldoende vervanging van militairen door burgers. Het Amerikaanse volk was van de dienstplicht bevrijd en dit was voldoende om de tradities uit het verleden voort te zetten. Het kostenaspect van een vrijwilligersleger was van secundair belang en werd verder vergeten.

Ook voor Nederland is dit aspect in een discussie over de dienstplicht niet uit te vlakken. Wordt de militair-burger-substitutie in een vrijwilligersleger achterwege gelaten, dan dienen we rekening te houden met een forse stijging van de pensioenlasten. Uit tabel 5.2. blijkt namelijk dat de kosten van beroepsmilitairen zo hoog zijin door

\footnotetext{
14 Zie hoofdstuk 2, paragraaf 2.

15 Zie voor en werduidelijking en uitbreiding hoofdstuk 7 wain dit proefschrift.

16 Charles Moskos, Larme de métier Americaine (1973-1990): Constat de carence; Fondation pour les études de deffense mationale, Parijs , februari 1991.
} 
de hoge pensioenlasten die beroepsmilitairen met zich mee brengen. Marinemensen gaan met 50-jaar met pensioen, de overige militairen met 55-jaar.

Een ander probleem bij de vervanging van militairen door burgers is dat deze substitutie alleen uitgevoerd kan worden in de niet-gevechtsfuncties. Het zijn echter de gevechtsfuncties die alle aandacht krijgen van de politiek en generale staven, walarbil het andere deel van de krijgsmacht, waar de meeste mensen werken, het onderspit delft. Dit will nogmaals zeggen dat de oplossing van dit soort problemen dan ook eerder te vinden is in de niet-gevechtsfuncties dan in de hoeveelheden tanks, schepen of vliegtuigen.

In tegenstelling tot de problemen met de substitutie tussen kapitaal en arbeid heeft de substitutie tussen burger en militair well als voordeel dat kostenbesparingen eerder zichtbaar worden voor politici. Daamaast is de vermaatschappelijking van de krijgsmacht door het grotere aandeel burgers voor politici ook een belangrijk punt.

Een groot praktisch probleem bij de verburgerlijking van de krijgsmacht is de militaire traditie. Een militaire traditie die nog eens aangescherpt wordt door het verlies van unform, rang, macht en status van de millitair indien deze burger wordt. Wil de vervanging van militairen door burgers werkelijk een succes worden, dan dient hier rekening mee te worden gehouden. In hoofdstuk 8, paragraaf 5 zullen we dit probleem nader onderzoeken en zullen we tevens oplossingen voor dit probleem aandragen.

\section{§5.5. De substitutie tussen onervaren en ervaren militairen}

Het militaire personeelssysteem is een gesloten systeem. Voor het overgrote deel van de militaire functies geldt dat personeel geworven wordt vanuit de eigen rangen. Ten einde voldoende ervaren militairen te krijgen is in een gesloten systeem als de krijgsmacht een adequate hoeveelheid jonge militairen noodzakelijk. Tussen de hoeveelheid ervaren en onervaren militairen bestaat een dynamisch evenwicht, omdat enerzijds een grote hoeveelheid jongeren kan betekenen dat er onvoldoende ruimte is voor doorstroming in de organisatie, maar anderzijds kan een gering aantal jongeren betekenen dat er minder selectiemogelijkheden zullen bestaan om de juiste mensen op de juiste plaats te krijgen.

De mix van ervaren en onervaren militairen speelt binnen de krijgsmacht zodoende een belangrijke rol. Vanuit een allocatieve zienswijze is het daarom van belang een onderscheid te maken tussen ervaren en onervaren millitairen en deze twee groepen als specifieke produktiefactoren te beschouwen.

De economische theorie leert ons dat voor zover onervaren en ervaren militairen substitueerbaar zijn, een verhoging van het loon voor de onervaren militairen zal leiden tot een herallocatie van middelen, waarbij onervaren millitairen worden vervangen door ervaren militairen. De praktijk geeft aan dat door de dienstplicht de krijgsmacht in grote mate steunt op onervaren krachten. Een stijging van de wedde van dienstplichtigen naar een beroepsniveau leert ons dat de mix van onervaren/ervaren militairen ten gunste van de ervaren militairen verandert. De vraag die hieraan vast gekoppeld zit is hoe groot deze verandering zal zijn. Een antwoord op deze vraag kan worden gegeven door de produktiviteit van de beide groepen onder de loep te nemen.

Als onervaren krachten werk doen dat beter door ervaren krachten gedaan kan worden, betekent dit dat er een verlies aan produktiviteit optreedt. Anders gesteld, onervaren krachten kunnen gesubstitueerd worden door ervaren krachten op een 
minder dan 1 op 1 basis met behoud van gevechtskracht. Onderzoek uit de Verenigde Staten laat zien dat 100 personen met een ervaring van vier jaar 180 onervaren krachten vervangen kunnen zonder verlies aan gevechtskracht. ${ }^{17}$ De substitutie van onervaren militairen door ervaren militairen kan dus een belangrijke produktiviteitsverbetering of kostenbesparing tot gevolg hebben.

Gezien het belang van de mix van onervaren en ervaren personeel binnen het allocatieproces doen we er goed aan naar de problemen te kijken die bij dit allocatieproces kunnen ontstaan. Ten eerste is er de constatering dat de krijgsmacht, als gevolg van de afwezigheid van schaarste, de mix van onervaren en ervaren personeel meer heeft gezien als een organisatievraagstuk dan als een vraagstuk van benodigde schaarse arbeid of een allocatieprobleem. In het geval van een vrijwilligersleger is zij tot het laatste verplicht. Ten tweede heeft de krijgsmacht senioren binnen haar gelederen altijd gezien als "supervisors" in plaats van uitvoerend personeel. Beroepsmilitairen zijn dan ook vaker achter een bureau te vinden dan in het veld. Tenslotte is het probleem er niet én van te veel personeel in te hoge rangen, maar een probleem van te veel mensen in niet-produktieve functies. Een generaal als pantserinfanterist kan produktiever zijn dan een generaal achter een bureau.

\section{§5.6. De personeelsbehoefte van de krijgsmacht in een vrijwilligersleger}

Dit hoofdstuk begon met Cooper's uitspraak dat:

"The force structure itself should be a function of the costs of the specific inputs".

Deze uitspraak is van wezenlijk belang willen we voldoende inzicht krijgen in de mogelijkheden over te stappen van een dienstplichtigenleger naar een vrijwilligersleger. Door het "gratis" karakter van dienstplichtigen is de behoefte aan onervaren militairen "oneindig" groot. In een vrijwilligersleger vervalt dit "gratis" karakter, en zal gezocht moeten worden naar alternatieven voor onervaren militairen.

In dit hoofdstuk hebben we gezien dat de alternatieve productiefactoren voor de krijgsmacht zeker voorhanden zijn en gezocht moeten worden in de inzet van kapitaal, burgers en ervaren militairen. Eigenlijk dient uitbesteding van taken daaraan toegevoegd te worden, doch wordt dit vooralsnog beschouwd als een combinatie van kapital- en burgersubstitutie. In hoofdstuk 7 zal nader worden ingegaan op de wisselwerking tussen maatschappij en krijgsmacht en zal op het fenomeen uitbesteding worden ingegaan. In dit hoofdstuk beperken we ons tot de alternatieven die reeds binnen de krijgsmacht aanwezig zijn.

In 1976 is de dienstplicht en de overgang naar een wrijwilligersleger nader onderzocht door de Commissie-Mommersteeg. ${ }^{18}$ Deze commissie concludeerde dat het wenselijk was de dienstplicht af te schaffen, maar dat overschakeling op een vrijwilligersleger praktisch niet mogelijk was. Tot eénzelfde conclusie kwam de CommissieMeijer in haar rapport "Naar dienstplicht nieuwe stijl" in 1992.

De mogelijkheid tot de overgang van een dienstplichtigenleger naar een vrijwilligersleger is afhankelijk van zowel het aanbod van vrijwilligers als de behoefte aan vrijwilligers. In hoofdstuk 6 zal het aambod van vrijwilligers nader aan de orde ko-

\footnotetext{
$17_{\text {Gay, Robert }} \mathrm{M}_{,}$Estimating the Cost of on-the-job Training in Military Occupation: A Methodology and Pilot Study, The Rand Corporation, Santa Monica 1974.

${ }^{18}$ Commissie-Mommersteeg, Verplicht of vrijwillig dienent, Den Haag, 1976.
} 
men. In deze paragraaf zal de behoefte van de krijgsmacht nader gekwantificeerd worden met behulp van de in dit hoofdstuk beschreven methoden. In hoofdstuk 6 zal de behoefte aan vrijwilligers ook geanalyseerd worden, maar dan met andere methoden. Beide methoden zijn complementair, maar worden voor het overzicht apart behandeld. Hier staat de beperking van de behoefte als gevolg van allocatieve aanpassingprocessen voorop. In hoofdstuk 6 zal het meer gaan om specifieke arbeidsmarktinstrumenten en de beperking van de behoefte aan vrijwilligers.

Met de analyse van de behoefte aan vrijwilligers kan worden gekeken of de Commissie-Meijer en de Commissie-Mommersteeg het bij het rechte eind hebben gehad met hun conclusie dat de overgang naar een vrijwilligersleger niet mogelijk was.

De Commissie-Meijer ging in haar analyses uit van de Defensienota 1991 en de Defensiebegroting 1992. In deze paragraaf wordt bij deze documenten aangesloten, zoals reeds eerder in dit hoofdstuk het geval was.

Tabel 5.1. van dit hoofdstuk leerde ons dat er 39.500 gevechtsfuncties zijn. Door kapitaal-arbeid-substitutie moet het mogelijk zijn $5 \%$ op de landmachtfuncties te besparen. Hierbij dient vooral gedacht te worden aan de Legerkorpstroepen binnen het Eerste Legerkorps.

De besparingen aan militairen door de substitutie tussen onervaren en ervaren militairen is bescheiden geschat op $10 \%$ van het aantal landmachtfuncties. Uit de studie van Gay ${ }^{19}$ blijkt dat deze besparing zelfs tot $45 \%$ procent kan oplopen, doch hier wordt voorzichtigheidshalve uitgegaan van een meer bescheiden percentage. De krijgsmacht dient echter wel aan dit percentage te werken door het stimuleren van onder andere lange-termijn contracten en het bevorderen van het opnieuw intreden van vroegere kort-verbandvrijwilligers. ${ }^{20}$

$\mathrm{Na}$ de uitvoering van de diverse substituties resten ons 35.000 militaire functies. Dit aantal van 35.000 is minder dan het aantal beroepsmilitairen dat in 1992 binnen de krijgsmacht reeds aanwezig was. ${ }^{21}$ Het aantal burgers neemt in een vrijwilligersleger flink toe. Volgens de Defensienota 1991 neemt het aantal burgers af naar ongeveer 17.000. Door de substitutie van militairen door burgers zijn er extra burgers nodig voor onderhoudsfuncties, bewakingsfuncties, kazernefuncties en opleidingsfuncties. De onderhoudsfuncties betreffen met name functies bij de marine en de luchtmacht en zijn voor de gehele krijgsmacht ingeschat op 10.000 .22 Het aantal bewakingsfuncties is geschat op 2.000 en bij de kazernefuncties dient gedacht te worden aan het kazernemanagement, magazijnbeheer, beheer van mobilisatiecomplexen en de verzorging van de mens. Het aantal functies dat hiermee gemoeid is, is geschat op 6.500.

De opleidingsfuncties zijn een afgeleide van het aantal militairen dat in opleiding is. Bij 35.000 gevechtsfuncties is uitgegaan van een verloop van 3.000 functies per jaar. ${ }^{23}$ Met een gemiddelde initiële opleidingstijd van 6 maanden zijn er steeds 1.500 militairen in opleiding, zoals ook naar voren komt in tabel 5.1. Een ervaringsregel uit de Verenigde Staten leert ons dat voor iedere persoon in opleiding éen trainer aanwezig moet zijn. Momenteel is deze verhouding 14:8, maar door een intensievere op-

\footnotetext{
19 Zie voetnoot 17 .

20 Zie hoofdstuk 6 , paragraaf 4 voor een uitgebreìde verhandeling over de mogelijkheden te komen tot een meer orvaren krijgsmacht.

21. Zio tabel 5.2. In 1992 kende Nederland 51.651 millitairen.

${ }^{22}$ De schattingen dienen met enige voorzichtigheid te worden geinterpreteerd, doch liggen net als de schatting van do gevech tsfuncties in tabel 5.2 . volgent exteme deskundigen niet wer van de werkelikheid af.

23 In 1992 kende de krijgsmacht een behoefte van 4.750 beroepsmillitairen per jaar op sen sterkte van ongeveer

51.000 beroepsmilitairen. Naar rato betekent dit dat een krijgsmacht van 35.000 beroepsmilitairen een behoefte van ongeveer 3.000 man heelt.
} 
leiding van beroepsmilitairen op meerdere terreinen moet uitgegaan worden van het feit dat deze verhouding zich zal optrekken tot 1:1. In total zijn er dus 1.500 burgers nodig voor de opleiding van militairen, waarbij opgemerkt dient te worden dat sommige burgers militaire ervaring moeten hebben willen zij de juiste opleiding kunnen verzorgen.

Dit alles resulteert in een geschat aantal extra burgers van 20.000 , zodat het totall aantal burgers op 37.000 komt. De Commissie-Mejier heeft de mogelijkheid tot de inzet van meer burgers nilet onderzocht, zodat ook niet bekend is of dit aantal beschikbaar is op de arbeidsmarkt.

De krijgsmacht kent na alle substituties in total 72.000 functies. In vergelijking met de uitgangssituatie van 112.000 betekent dit dat er 40.000 functies zullen verdwijnen. De 40.000 functies bevatten ondermeer de voorgenomen verminderingen die voortvloeien uit de Defensienota 1991, de produktiviteitswinst door de substitutie van arbeid door kapitaal, de produktiviteitswinst door de substitutie van onervaren door ervaren militairen en de verminderde bureaucratie die de overgang naar een meer burger georiënteerde krijgsmacht impliceert.

Doch deze reducties vallen in het niet bij de vermindering van het aantal functies in het opleidingscircuit. Alleen al bij de Koninklijke Landmacht zijn permanent 22.000 mensen bezig met het krijgen of het geven van een opleiding. Een aantal dat reduceert tot 3.000 in het geval van een vrijwilligersleger.

De commissie-Meijer kwam tot geheel andere cijfers. De behoefte aan beroepsmilitairen had zij veel hoger ingeschat, omdat zij uitging van de vervanging van een dienstplichtige door én beroepsmilitair.

De Commissie-Mommersteeg onderzocht de dienstplicht in 1976. Voor de nadere analyse van het rapport van deze Commissie gaan we uit van de internationale veiligheidssituatie zoals beschreven is in de Defensienota 1974. Volgens de Defensienota 1974 kende de krijgsmacht in 1974 een behoefte van 99.000 millitairen en 25.800 burgers. Bij schaarste op de arbeidsmarkt door de afschaffing van de dienstplicht resulteert dit in een behoefte aan militairen van ongeveer 45.000 . Een schatting van de behoefte aan burgers volgens de hiervoor gebruikte methode levert dan het aantal van 48.000 burgers op.

Op basis van deze cijfers kunnen we niet anders concluderen dan dat de overschakeling op een vrijwilligersleger ook ten tijde van de Commissie Mommersteeg mogelijk moet zijn geweest, omdat deze cijfers weinig afwijken van de cijfers van dè Commissie-Meijer.

Toch zit hier een adder onder het gras. De analyses wijzen er op dat de overschakelijking op een vrijwilligersleger mogelijk is indien we de vredesorganisatie van een dienstplichtigenleger met een vrijwilligersleger vergelijken. Doch de krijgsmacht bereidt zich voor op oorlog en in een oorlog spelen ook de mobilisabele eenheden een rol. Pas als er voldoende alternatieven aanwezig zijn om ook het mobilisabele deel van de krijgsmacht te vervangen kunnen we pas met zekerheid zeggen dat de analyses van de Commissie-Meijer en de Commissie-Mommersteeg foutief zijn geweest. De mobilisabele eenheden worden pas besproken in hoofdstuk 8 , omdat de alternatieven voor de mobilisabele eenheden pas echt duidelijk worden na de behandeling van het aanbod van vrijwilligers in hoofdstuk 6 en de wisselwerking tussen maatschappij en krijgsmacht in hoofdstuk 7 . Toch blijft overeind staan dat de organisatie van een vrijwilligersleger in vredestijd geen belemmeringen met zich meebrengt. Noch in 1992, noch in 1976. 
\$5.7. De budgettaire consequenties van de overgang van een dienstplichtigenleger naar een vrijwilligersleger en de "excess burden" van een dienstplichtigenleger

Nu we de behoefte aan militairen en burgers gespecificeerd hebben, kunnen we deze combineren met de kosten wan deze produktiefactoren om de budgettaire consequenties van de overgang van een dienstplichtigenleger naar een vrijwilligersleger onder ogen te zien.

Zou op basis van de cijfers uit 1992 worden overgestapt op de in paragraaf 5.6 . genoiemde aantallen burgers en militairen dan zouden de personeelskosten 6,4 miljard gulden bedragen: burgers 2.436 miljoen gulden, militairen 2.466 milloen $^{24}$ gulden en pensicenlasten 1.517 miljoen gulden. Op lange termijn kunnen de personeelslasten verder dalen tot 5,1 miljard gulden door een relatieve verjonging van het beroepsmilitairembestand en de afname van de pensioenlasten. ${ }^{25}$ In 1992 bedroegen de personeelslasten 7,7 miljard gulden per jaar. Afschaffing van de dienstplicht in combinatie met de reeds voorgenomen reducties in de Defensienota 1991 kan op lange termijn leiden tot een besparing op de personeelskosten van 2,6 miljard gulden per jaar ten opzichte van 1992, waarbij dus het overgrote deel van dit bedrag wordt opgebracht door de lagere opleidingskosten en de daling van de pensioenkosten.

Op korte termijn zal dit bedrag waarschijnlijk lager zijn, omdat er als gevolg van de herstructurering een aantal arbeidsbesparende investeringen plaats dienen te vinden. Doch op lange termijn zullen ook de materiaallasten afnemen en kan de afschaffing van de dienstplicht veel geld opleveren. Een vrijwilligersleger is dus zeker niet kostbaar, zoals de Commissie-Meijer in haar rapport stelt.

De kostenbesparingen welke gerealiseerd hadden kunnen worden, indien de Commissie-Mommersteeg het groene licht had gegeven voor een vrijwilligersleger zijn inzoverre interessant, dat zij zicht kunnen geven op de "excess burden" van de dienstplicht.

In tegenstelling tot de Commissie-Meijer moest de Commissie-Mommersteeg een oordeel geven over de dienstplicht in een periode waarin geen sprake was van een substantiële vermindering van de gevechtskracht als gevolg van de gewijzigde internationale verhoudingen. Het hilervoor genoemde bedrag van 2,6 miljard gulden. heeft namelijk als nadeel dat zij deels ontstaat door de vermindering van de benodigde gevechtskracht en deels door de krijgsmacht te confronteren met de werkelijke kosten van dienstplichtigen. Door dit gemengde karakter kan de "excess burden' van de dienstplichtbelasting echter niet goed gemeten worden. Een analyse van de gegevens van de Commissie-Mommersteeg geeft ons wel de mogelijkheid "de lasten van de dienstplicht" te onderzoeken, die "bovenop de geinde dienstplichtbelasting drukken".

In 1976 hadden we 99.000 militairen en 25.800 burgers. In guldens van 1992 zou dit een bedrag van 8.502 miljoen gulden ${ }^{26}$ aan personeelslasten geven. In een vrijwilligersleger hebben we vervolgens 45.000 militairen en 48.000 burgers. Dit geeft een bedrag van 6.527 miljoen gullen ${ }^{27}$ aan personeelslasten. Vervolgens hebben we de kosten van opleiding, kleding en huisvesting. In hoofdstuk 4 hebben we gezien dat de opleiding van dienstplichtigen 500 miljoen gulden per jaar kost. Deze opleidingskosten zitten grotendeels al verdisconteerd in de personeelskosten en zullen daarom niet

\footnotetext{
24 Burgers $37.000 \times 65.848=2.436$ miljoen gulden, Militairen $=35.000 \times 70.461=2.466$ miljoen. gulden .

25 Burgers: $37.000 \times 65.848=2.436$ miljoen gulden. Militairen: $35,000 \times 74.797=2.617$ miljoen gulden.

26 Militairen $99.000 \times 68.730=6.804$ miljoen gulden + burgers $25.800 \times 65.848=1.698$ miljoen gulden.

27 Militairen $45,000 \times 74.797=3.366$ miljoen gulden + burgers $48.000 \times 65.848=3.161$ miljoen galden
} 
worden betrokken in de berekening van de "excess burden". Dit om dubbeltellingen te voorkomen. De kosten van kleding en huisvesting ( 265 miljoen gulden) zullen bij een vrijwilligersleger voor een deel ook bestaan. In een vrijwilligersleger neemt het aantal militairen af met ongeveer $55 \%{ }^{28}$ Indien we een evenredige afname van de kosten van huisvesting en kleding veronderstellen betekent dit een overblijvend bedrag aan kleding- en huisvestingskosten van 120 milloen gulden, of te wel een "excess burden" van 145 miljoen gulden.

De kosten van keuring van dienstplichtigen houden ook een "excess burden" in (22 miljoen gulden) evenals de kosten die worden gemaakt door "weigeryuppies" (2,5 miljoen gulden) en de Wet Gewetensbezwaarden ( 25 miljoen gulden). Totaal resulteert dit in een last voor de maatschappij bovenop de geinde dienstplichtbelasting van zo'n 2.170 miljoen gulden per jaar, op basis van de grootte van de krijgsmacht in 1976 en de kostencijfers voor 1992.

De dienstplicht verstoort het allocatieproces. Door de verandering van de relatieve prijzen van produktiefactoren ontstaat een aanzienlijke "excess-burden" van zo'n 2 miljard gulden per jaar.

\section{\$5.8. Conclusies}

Het centrale probleem in een onderzoek naar de haalbaarheid van een vrijwilligersleger is het schaarsteprobleem. De mogelijkheid van een vrijwilligersleger hangt in grote mate samen met de gevoeligheid die de krijgsmacht tentoon spreidt voor veranderingen in de kosten van de produktiefactoren, die het gevolg zijn van het afschaffen van de dienstplicht. Dienstplicht zorgt voor een kunstmatige prijsstructuur in de krijgsmacht welke resulteert in een inefficiënte organisatie met teveel mensen, teveel militairen en teveel onervaren krachten. In de krijgsmacht is duidelijk sprake van $X$-inefficiëntie, zoals beschreven door Leibenstein.

De behoefte aan produktiefactoren verschuift in een vrijwilligersleger van onervaren militairen naar kapitaal, burgers en ervaren militairen. Schaarste maakt het zoeken naar alternatieven vruchtbaar. Dit geldt zowel voor de organisatie van de krijgsmacht in vredestijd, zoals we in dit hoofdstuk hebben gezien, maar geldt evenzeer voor de vulling van de mobilisabele eenheden, zoals we later in hoofdstuk 8 zullen zien. Een onderzoek naar de haalbaarheid van een vrijwilligersleger zal zich bewust moeten zijn van het feit dat er met een vrijwilligersleger een volkomen nieuw analy sekader ontstaat in vergelijking met een dienstplichtigenleger.

Zowel de commissie-Meijer als de commissie-Mommersteeg zijn zich niet bewust van dit nieuwe kader en komen dan ook niet tot een oplossing.

In dit hoofdstuk hebben we tevens kunnen zien dat de in dit hoofdstuk gebruikte methoden niet alleen van belang zijn bij het beoordelen van de dienstplicht. $\mathrm{Zij}$ hebben tevens de mogelijkheden aangereikt kostenbesparingen in de krijgsmacht te realiseren zonder dat daardoor de sterkte van de gevechtskracht hoeft te worden aangetast. De krijgsmacht kan veel doelmatiger en dit strekt iedereen in de Nederlandse samenleving tot voordeel.

$28(99.000-45.000) / 99.000=0.55$ 
Appendix 5.1.

\begin{tabular}{l|l|c|c|c|}
\hline $\begin{array}{l}\text { Jaarloonklasse } \\
16-24 \text { jarigen(gld) }\end{array}$ & $\begin{array}{l}\text { aantal } \\
\text { jongeren } \\
\text { in \% }\end{array}$ & $\begin{array}{l}\text { Jongens } \\
\text { cum. }\end{array}$ & $\begin{array}{l}\text { Dienst- } \\
\text { plichtig abs. }\end{array}$ \\
\hline 1 & $\mathrm{~A}$ & $\mathrm{~B}$ & $\mathrm{C}$ & \multicolumn{1}{|c|}{$\mathrm{D}$} \\
\hline 2 & $10.000-12.000$ & 5,6 & 6.640 & 2.507 \\
3 & $12.000-12.500$ & 6,4 & 14.228 & 2.865 \\
4 & $12.500-15.000$ & 1,6 & 16.125 & 716 \\
5 & $15.000-17.500$ & 9,6 & 27.507 & 4.297 \\
6 & $17.500-17.684(\mathrm{~L})$ & 13,9 & 43.988 & 6.222 \\
7 & $17.684-17.913$ & 1,7 & 45.987 & 761 \\
8 & $17.913-19.0950)$ & 16 & 48.493 & 939 \\
9 & $19.095-20.000$ & 8,8 & 61.316 & 4.838 \\
10 & $20.000-22.500$ & 21,9 & 71.140 & 3.715 \\
11 & $22.500-25.000$ & 11,0 & 110.106 & 9.803 \\
12 & $25.000-27.500$ & 4,1 & 115.009 & 4.924 \\
13 & $27.500-30.000$ & 1,7 & 117.024 & 716 \\
14 & $30.000-32.500$ & 0,6 & 117.736 & 269 \\
15 & $32.500-35.000$ & 0,3 & 118.091 & 134 \\
16 & $35.000-37.500$ & 0,1 & 118.210 & 45 \\
& & & & $\Sigma 44.761(\mathrm{G})$ \\
\hline
\end{tabular}

Deze tabel is reeds eerder gebruikt in hoofdstuk 4 (tabel 4.1.). Voor een verklaring van alle getallen, zie de inhoud van hoofdstuk 4.

Keuringspercentage $(\mathrm{E})=73,0 \%$ goedgekeurd.

Wedde(F) $=$ fl 12.000,--

1. Krappe definitie dienstplichtbelasting $(\mathrm{H})=1,2 \sum_{i=3}^{15}\left(\left(A_{i}-F\right) D_{i}\right)=360$ miljoen.

2. Voor 44.761 dienstplichtigen zijn $\mathrm{G} / \mathrm{E}=61.316(8 \mathrm{C})$ jongens nodig. Loon $(J)=\mathrm{fl}$ $19.095,-(8 \mathrm{~A})$.

3. Ruime definitie dienstplichtbelasting $=(J-F) G+\sum_{i=8}^{16}\left(\left(1,2 A_{i}-J\right) D_{i}\right)=450$ miljoen gulden.

$4.33 .570=\mathrm{K} \cdot \mathrm{K} / \mathrm{E}=45.987(6 \mathrm{C}) \cdot \operatorname{Loon}(\mathrm{L})=17.684(6 \mathrm{~A})$.

5. Verveling $\mathrm{LSPDF}=\sum_{i=3}^{\mathrm{B}}\left(\left(A_{i}-F\right) D_{i}-0,5\left(G-\left(D_{1}+D_{2}\right)\right)(L-F)=40,5\right.$ miljoen.

- Verveling loterijsysteem $=1 / 1,2 H-0,5\left(G-\left(D_{1}+D_{2}\right)\right)(L-F)=188$ miljoen.

Cijfers A en B: Statistisch jaarboek 1991, CBS blz. 99.

Cijfers C, D, E en G: Jaaroverzicht dienstplichtgegevens 1988, Min. van Defensie.

Cijfers F: Archief VVDM. 


\title{
De vraag naar en het aanbod van beroepsmilitairen
}

\begin{abstract}
"Vergroting van het geinteresseerde aanbod en het beter bereiken van het aanbod kan betekenen dat de behoefte nipt wordt vervuld, maar voor een overschakeling naar een kaderwrijwilligerskrijgsmacht is het nodig dat defersie haar behoefte en procedures kritisch tegen het licht houdt".

Research voor Beleid in "Naar dienstplicht nieuwe stij1"-rapport Commissie Meijer, Den Haag 1992.
\end{abstract}

In de hoofdstukken vier en vijf van dit proefschrift hebben we de dienstplicht onderzocht met behulp van het begrip "opportunity costs". Met de "opportunity costs"- gedachte hebben we de sociale kosten van de dienstplicht geanalyseerd in termen van de dienstplichtbelasting en hebben we deze sociale kosten ingebracht in de sociale kostprijs van dienstplichtigen om daarmee het allocatievraagstuk in de krijgsmacht te analyseren.

In een onderzoek naar de dienstplicht staat dus de zoektocht naar de alternatieve schaarse situatie voorop. Deze alternatieve situatie is het vrijwilligersleger. Willen we de maatschappelijke kosten van dienstplicht in volle mate kunnen aanschouwen, dan dienen we ook het vrijwilligersleger te analyseren volgens de gedachten van de "opportunity costs".

In dit hoofdstuk komt deze analysemethode op een aantal wijzen naar voren rond drie centrale onderwerpen. Het eerste onderwerp betreft het aanbod van vrijwilligers voor de krijgsmacht. Voordat vrijwilligers zich beschikbaar stellen ten behoeve van een arbeidsplaats in de krijgsmacht zullen zij een bepaalde afweging maken. In dit afwegingsproces zal het salaris en de intrinsieke waarde, zoals de vorming van "human capital" en de mate van "avontuur", van een arbeidsplaats in de krijgsmacht door een potentiële vrijwilliger tegenover de alternatieve mogelijkheden in de burgermatschappij worden gesteld, waardoor zicht wordt gekregen op de alternatieve kosten van het afwegingsproces.

Het afwegingsproces, of de zoektocht naar de "'opportunity costs", van een potentiële vrijwilliger zal in paragraaf 6.1 nader onder de loep worden genomen. Dit zal in deze paragraaf in vrij algemene termen geschieden, omdat voor een concrete invulling van de afweging ook de specifieke taken van de krijgmacht bekend moeten zijn. In paragraaf 6.2 worden deze taken van de krijgsmacht nadrukkelijk in de afweging betrokken en zal worden onderzocht hoe de mogelijkheden en verlangens in termen van salaris en andere beloningen van de potentiële vrijwilligers het best kunnen aansluiten bij de taken van de krijgsmacht. In deze twee paragrafen zal tevens worden 
ingegaan op welke wijze de krijgsmacht dient te reageren wil zij kunnen aansluiten bij de wensen van de potentiele vrijwilligers, om zodoende de potentiele vrijwilligers de kans te geven volledig gebruik te maken van de alternatieve mogelijkheden, zowel in de krijgsmacht als in de burgermatschappij.

Het tweede centrale onderwerp van dit hoofdstuk sluit bij deze laatste gedachte aan. In paragraaf 6.3 wordt namelijk gekeken naar het selectieproces in de krijgsmacht. Door middel van selectie maakt de krijgsmacht een bepaalde keuze uit het aanbod van vrijwilligers. Dit keuzeproces brengt bepaalde kosten met zilch mee. Daarbij hoeft niet alleen gedacht te worden in termen van verliezen van "opportunities" van een vrijwilliger, maar kan ook in maatschappelijke termen over "opportunity costs" worden gesproken. Juist bij het selectieproces is de vergelijking tussen een dienstplichtigenleger en een vrijwilligersleger in termen van "opportunity costs" van wezenlijk belang, omdat met behulp van deze "opportunity costs" kan worden bekeken, welke selectie-eisen er gesteld moeten worden onder welk soort leger.

Tenslotte zal in paragraaf 6.4 het derde centrale onderwerp van dit hoofdstuk worden besproken: de vraag naar vrijwilligers. Dit onderwerp is voor het onderscheid tussen een dienstplichtigenleger en een vrijwilligersleger en dus voor de "opportunity costs" van de dienstplicht van belang, omdat aan de hand van de vraag naar vrijwilligers in een vrijwilligersleger kan worden gekeken, welke instituties in de krijgsmacht veranderd moeten worden, wil de krijgsmacht de mogelijkheden van vrijwilligers zo goed mogelijk benutten om daarmee tevens de kosten van een vrijwilligersleger zo laag mogelijk te houden. Mede door de dienstplicht zijn bepaalde instituties, die in een vrijwiligersleger een negatief effect hebben, immers nog steeds aanwezig in de krijgsmacht.

\section{$\$ 6.1$. Het aanbod van potentiêle vrijwilligers ${ }^{1}$}

Bij een analyse van het aanbod van vrijwilligers en het naar boven halen van de "opportunity costs" van vrijwilligers zal worden uitgegaan van de traditionele arbeidsaanbodtheorie. Uit deze theorie volgt dat de elementen die van invloed zijn op de beslissing zich aan te melden als vrijwilliger ieder apart besproken dienen te worden. Deze elementen zullen vervolgens worden gecombineerd met de taken en de organisatie van de krijgmacht in paragraaf 6.2., om op deze wijze tot een volledige arbeidsaanbodtheorie voor de krijgsmacht te komen.

De elementen die van invloed zijn op het beroep militair zijn als volgt onder te verdelen: 1) de primaire arbeidswoorwaarden in de krijgsmacht, 2) de secundaire arbeidsvoorwaarden in de krijgsmacht, 3) de arbeidsomstandigheden in de krijgsmacht, 4) de werkgelegenheidssituatie, arbeidsvoorwaarden, arbeidsomstandigheden in de civiele burgermaatschappij, 5) de bevolkingssamenstelling van de groep waaruit geworven moet worden en 6) de informatiestromen die potentiële vrijwilligers tegemoet komen.

Van de primaire arbeidsvoorwaarden is het salaris van de militair de belangrijkste component. Andere onderdelen van de primaire arbeidsvoorwaarden zijn de duur van het contract, de diverse taken welke binnen de krijgsmacht te vervullen zijn en het levensrisico dat aan bepaalde taken verbonden zit.

\footnotetext{
1 Deze paragraaf is ondermeer gebaseerd op: G.S. Becker, "Investment in Human Capital: a Theoretical Analysis, "Joumall of Political Economy, vol.70, 1962; G. J. Stigler, "Information in the Labor Market", The Toumal of Political Economy, vol. 70, 1962 en NorBerFN, Nordic Standby Forces in United Nations Service, Stockholm, 1974.
} 
In de primaire arbeidsvoorwaarden zijn vele gradaties te vinden, omdat de krijgsmacht verschillende opties in haar takenpakket kan bieden. Dit betekent tevens dat de mogelijkheid tot "matching" van wensen van de vrijwilliger en behoeften van de krijgsmacht zal bestaan. "Matchung" houdt in dit geval in dat er meer mensen kunnen worden aangenomen dan in eerste instantie voor mogelijk werd geacht, ondat het door de grote variabiliteit in wensen en mogelijkheden gemakkelijker wordt de voorkeuren van potentiele vrijwilligers te koppelen aan de wensen van de krijgsmacht. In paragraaf 6.2. zal hier verder op worden ingegaan.

De tweede groep elementen zijn de secundaire arbeidsvoorwaarden. Hierbij komen zaken als pensionering, additionele opleidingen, promotie en vakanties kijken. Voor de krijgsmacht zijn de secundaire arbeidsomstandigheden zeer belangrijk. Misschien nog wel belangrijker dan in de burgermaatschappij. Dit heeft te maken met het gesloten personeelssysteem en het beloningssysteem dat de krijgsmacht kent. De krijgsmacht kent een gesloten personeelssysteem, omdat het voor vrijwilligers vrijwel onmogelijk is om van buiten af de hogere rangen te kunnen binnen treden. De hogere rangen worden uit de eigen gelederen geselecteerd. Daarnaast kent de krijgsmacht een "up-or-out" personeelsbeleid. Dit betekent dat iemand niet rustig dezelfde baan kan vervullen gedurende zijn gehele diensttijd. In een gesloten personeelssysteem moet in principe iedereen in de hiërarchie doorstromen naar boven om plaats te maken voor nieuwkomers. Is dit niet gewild of is er verderop in de hiërarchie geen plaats, dan rest er niets anders dan een baan te zoeken in de burgermaatschappij. De secundaire arbeidsvoorwaarden zijn een belangrijke prikkel voor het personeel dat reeds in de krijgsmacht aanwezig is. Omdat het zittende personeel de centrale spil vormt in het onderzoek naar de behoefte aan beroepsmilitairen wordt hier volstaan met het verwijzen naar paragraaf 6.4. In deze paragraaf zal ook worden ingegaan op het beloningssysteem in de krijgsmacht.

Voor de potentiële nieuwe vrijwilliger spelen de secundaire arbeidsvoorwaarden een minder belangrijke rol, behalve waar het gaat om de additionele burgeropleidingen. Deze opleidingen zorgen voor de opbouw van "human capital" in de krijgsmacht en kunnen een belangrijke rol spelen bij de wensen van de potentiële vrijwilliger. Door de "matching" van wensen van de vrijwilliger en de wensen van de krijgsmacht spelen de additionele opleidingen een belangrijke rol in een vrijwilligersleger. In paragraaf 6.2 . wordt dit verder uitgediept.

Een volgende groep elementen waarmee een potentiële vrijwilliger rekening zal houden bij zijn keuze toe te treden tot de krijgsmacht, zijn de arbeidsomstandigheden in de krijgsmacht. Zo zijn daar de afstand van de woonplaats tot de kazerne, de huisvesting op de kazerne, de zwaarte van het werk, de mate van verveling, de per" soonlijke verhoudingen tussen het personeel en de mate van onnodige discipline. Ten tijde van de dierstplicht staan de arbeidsomstandigheden zwaar onder druk, omdat: er door het "oneindige" aanbod van arbeidskrachten weinig prikkels voor de krijgsmacht bestaan om tegemoet te komen aan de wensen van de werknemers op dit gebied. Slechte arbeidsomstandigheden hebben niet alleen effect op de dienstplichtigen zelf, maar verder op alle personeelsleden die met dienstplichtigen te maken hebben. En dit is wrijwell iedereen. Slechte arbeidsomstandigheden hebben bovendien een negatief effect op de bereidwilligheid van een potentielle vrijwilliger toe te treden tot de krifgsmacht.

Tot nu hebben we gezien dat indien de primaire arbeidsvoorwarden, de secundaire arbeidsvoorwaarden en de arbeidsomstandigheden verbeteren er meer mensen bereid zullen zijn zich als vrijwilliger aan te melden. De vraag is echter hoe ver de krijgsmacht dient te gaan in de verbetering van de diverse voorwaarden. Daarom is 
het belangrijk de situatie in de krijgsmacht te vergelijken met de arbeidswoorwaarden en arbeidsomstandigheden in de burgermaatschappij. Op plaatsen waar de krijgsmacht een grote achterstand heeft, is het noodzakelijk dat zij zo spoedig mogelijk actie onderneemt om deze achterstand te verkleinen, en op plaatsen waar de krijgmacht een voorsprong of kleine achterstand heeft, kan met een mindere inspanning worden volstaan. Wil de krijgsmacht in het gezichtsveld komen van een potentiële vrijwilliger dan zal zij moeten kunnen concurreren met andere sectoren in de burgermaatschappij, omdat de potentiele vrijwilliger een afweging maakt tussen de verschillende mogelijkheden en zal kiezen voor die baan waarbij de mogelijkheden voor hem of haar het grootst zijn. Deze concurrentie zal heviger zijn naarmate de behoefte van de krijgsmacht groter is, de bevolking ontgroent of de werkloosheid dalende is.

De laatste factor welke van invloed is op het aanbod van vrijwilligers is de informatie die een potentiële vrijwilliger bereikt over de krijgsmacht: Hierbij dient gedacht te worden aan wervers in het veld, advertenties in de kranten en tijdschriften, reclame op radio en televisie en publiciteit. Het hoofddoel van deze wervingsactiviteiten is de potentiële vrijwilliger bekend te maken met de mogelijkheden binnen de krijgsmacht werk te vinden. Belangrijke nevenvoorwaarde daarbij is dat de informatie zo reëel en betrouwbaar mogelijk is en dat de informatie zich tevens richt op alle elementen die een beroep in de krijgsmacht aantrekkelijk kunnen maken. ${ }^{2}$

Het bovenstaande heeft een groot aantal elementen laten zien welke van invloed zijn op de bereidheid om als vrijwilliger in de krijgsmacht plaats te nemen. Indien we deze elementen nader structureren kunnen we de volgende vrijwilligersaanbod-functie construeren:

$E=f(W, P, S, A, B W, B, U, R)$

waarbij:

$\mathrm{E}=$ aanbod van vrijwilligers

$W=$ salaris van militairen

$\mathrm{P}=$ overige primaire arbeidsvoorwaarden

$\mathrm{S}=$ secundaire arbeidsvoorwaarden

$\mathrm{A}=$ arbeidsomstandigheden

$B W=$ arbeidsvoorwaarden en arbeidsomstandigheden in de burgermaatschappij

$B=$ de bevolkingssamenstelling

$U=$ de werkloosheid

$\mathrm{R}=$ de wervingsinspanningen

\footnotetext{
${ }^{2}$ Do werving wan beroepsmilltairen voor de luchtmobiele brigade van de Koninklijke Landmacht last zien dat de krijggmacht zich moeizaam bew ust wordt van alle aspecten van het beroep militair. In de commencials wordt ingespeeld op het avontururlitke karakter van de krijgsmacht, zonder dat wondt ingegaan op de gevaren die daaraan verbonden zijt. Dit makkt de neclamespot irretel mot alle kwalijke gevolgen van dien. Dat de werving niet goed verzorgd is, blijkt ook in de praktijk. Uit de Volkskrant van 20 november 1992: "Do eerste lichting van de luchtmobiele brigade kampt met een groot aantal uitvallers. In de serste twee maanden van de opleiding hebben 30 van de 180 bercepssoldaten hum ontslag in ged"̈end. Bellangrijkste oorzaken zouden zijm de zwaarte van de opleiding en het ontbeken van transporthelicopters. In tegenstelling tot wat de wervingscampagne van Diefensie suggeneert, moet er veel worden gelopen. Het beeld opgercepen door de spannende televisiespotjes, de kleurenbrochures en posters met soldaten in gevechtstente die in het veld uit ten helicopter springen, sttrookt tot dusver niet met de werkelujkhaid. Tijdens te oefeningen moeten de manschappen zichi verplat tsen per bus, legerturuck en vooral per voet",
} 
Vergelijking 6.1. kan versimpeld worden, indien we veronderstellen dat het aanbod van vrijwilligers proportioneel is aan de bevolkingssamenstelling en dat vrijwilligers ten aanzien van de arbeidsvoorwaarden en arbeidsomstandigheden vooral kijken naar de alternatieve burgersituatie.

$E / B=f[(W / B W),(P / B W),(S / B W),(A / B W), U, R]$

Bij de bespreking van de diverse elementen van het aanbod van vrijwilligers hebben we al even stil gestaan bij het teken van iedere variabele in vergelijking 6.2 . We zullen dit nu iets uitgebreider doen.

De variabele $\mathrm{W} / \mathrm{BW}$ heeft een positief teken. Dit volgt ondermeer uit de eilandentheorie van Edmund S. Phelps. ${ }^{3}$ Deze theorie stelt dat mensen bij de keuze voor een baan uitgaan van een bepaald reserveringloon. Willen zij een baan accepteren, dan dient het geboden loon het reserveringsloon te overschrijden. Het reserveringsloon is gebaseerd op verwachtingen omtrent wat andere mensen in het zelfde soort beroep verdienen, advertenties, mond-tot-mond reclame en andere factoren. De potentiële banen zijn verdeeld over een aantal eilanden. Om voldoende informatie over de banen te kunnen krijgen, zal een werkzoekende ieder eiland moeten bezoeken om de karakteristieken van die baan te onderzoeken. Dit zoekproces kost tijd en des te langer het zoekproces des te langer de werkloosheid. Naarmate een werkzoekende beschikt over complete informatie zal hij zo snel als mogelijk de meest geschikte baan vinden en zich aanbieden aan de werkgever. Echter in onze eilandenwereld is er eerder sprake van imperfecte informatie dan van perfecte informatie, omdat de informatie over de eillanden verspreid is. Informatie is dus kostbaar. Zolang de karakteristieken van de baan niet voldoen aan het reserveringsloon, dat een potentiële vrijwilliger in gedachte heeft, blijft deze potentiële vrijwilliger werkzoekend. Pas als de drempel van het reserveringsloon wordt overschreden zal hij zich aanbieden en behoort hij tot het arbeidsaanbod. Hierbij geldt natuurlijk dat het eiland dat de beste karakteristieken heeft ook het grootste aanbod zal hebben.

Met andere woorden, indien de salariskarakteristieken van de krijgsmacht beter zijn dan de salariskarakteristieken van een alternatieve sector zal de krijgsmacht een voorsprong hebben bij het aantrekken van vrijwilligers. Of een vrijwilliger ook wordt aangenomen hangt vervolgens van de werkgever af.

Aan het salaris als component van het reserveringsloon zitten niet alleen materiële aspecten. Het salaris speelt ook een psychologische rol. Dit wordt duidelijk indien de wervingsresultaten van vrijwilligers van de diverse krijgsmachtdelen naast elkaar worden gelegd. Uit deze resultaten blijkt dat de Koninklijke Marine en Koninklijke Luchtmacht weinig moeite hebben met het werven van vrijwilligers. De Koninklijke Landmacht daarentegen heeft veel meer moeite vrijwilligers aan zich te binden.

De oorzaak van de wervingsproblemen bij de Koninklijke Landmacht is ondermeer gelegen in de lage status van het beroep militair. Als indicator van de status van een beroep wordt veelal het gemiddelde loon van dat beroep gebruikt. De gemiddelde lonen in de Koninklijke Marine en de Koninklijke Luchtmacht zijn veel hoger dan het gemiddelde loon in de Koninklijke Landmacht. Dat de lonen in de Koninklijke Landmacht veel lager zijn komt door de aanwezigheid van grote aantal-

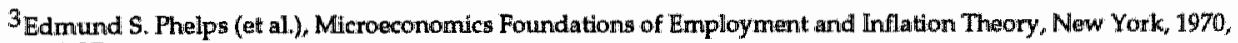
blz. 1-27. 
len dienstplichtigen met een wedde welke ver onder het minimumloon ligt. Uit de koppeling van het gemiddelde loon aan de status van het beroep volgt automatisch dat de Koninklijke Landmacht als werkgever voor velen een lage status heeft. Dit wordt nog eens versterkt door het feit dat als gevolg van de lage waarde van arbeid binnen de Koninklijke Landmacht veel werk door de produktiefactor arbeid wordt verricht, terwijl dat zelfde werk in andere sectoren met een normale kapitaal-arbeidverhouding aan machines wordt overgelaten. Werk dat vaak zwaar en smerig is.

Vergelijking 6.2. laat ons zien dat door de lage status en de lage gemiddelde lonen het aanbod van vrijwilligers in de krijgsmacht achter zal blijven bij andere sectoren. Wil militaire arbeid duidelijk in beeld komen bij de schaarse jongeren dan zal de krijgsmacht moeten concurreren met de burgermaatschappij. Of in termen van vergelijking 6.2. de verhouding (W/BW) zal minstens 1 moeten zijn.

Nu we het salaris als component van de primaire arbeidsvoorwaarden hebben besproken, stappen we over naar de overige primaire arbeidsvoorwaarden. Onderdelen van de overige primaire arbeidvoorwaarden zijn de duur van het contract, de taken welke binnen de krijgsmacht uitgeoefend kunnen worden en het levensrisico van een baan binnen de krijgsmacht.

De duur van een contract heeft een tweeledig karakter. Enerzijds geeft een langdurig contract een langdurige bestaanszekerheid, maar anderzijds geeft een contract ook problemen indien mogelijkheden tot verbetering worden tegengehouden door contractverplichtingen. Het effect van een langer contract op het aanbod van vrijwilligers is dus op het eerste gezicht niet geheel duidelijk. De mogelijkheden voor het verbreken van het contract speelt vooral voor mensen die al in de krijgsmacht aanwezig zijn en niet voor nieuwe vrijwilligers. Omdat dit onderwerp uitgebreid aan de orde komt in paragraaf 6.4. wordt op deze plaats hier naar verwezen. Dit wil overigens niet zeggen dat voor nieuwe vrijwilligers dit element niet belangrijk is. Wel is het zo dat contractverplichtingen voor nieuwe vrijwilligers een niet zo hoge prioriteit hebben.

Langdurige contracten bieden ontegenzeggelijk een langere bestaanszekerheid en. zullen daardoor tot op zekere hoogte bijdragen aan een groter aanbod van vrijwilligers. Niettemin adviseert de Maatschappelijke Raad voor de Krijgsmacht in haar rapport over contractduur, de contracten kort te houden. ${ }^{4} \mathrm{Zij}$ komt tot deze advisering door te kijken naar de inhoud van de functies voor soldaten. Beroepssoldaten hebben in het verleden veelal een functie met een specifiek militair karakter uitgeoefend. Een functie met niet zoveel inhoud. Echter, doordat de internationale sittuatie sinds 1989 drastisch veranderd is, zijn ook de taken voor de soldaat veranderd. Had de Koninklijke Landmacht vroeger voornamelijk als taak de Noord-Duitse laagvlakte te beschermen, nu zijn de Navo-taken niet zo duidelijk meer en zijn de taken op het gebied van de Verenigde Naties drastisch uitgebreid. Juist de VN-taken zorgen er voor dat het beroep militair meer inhoud gaat krijgen.

De toekomstige militair zal iemand zijn die naast het omgaan met wapens ook voorbereid is op een taak van bemiddeling, verzoening en onderhandeling. Hij zal meerdere taken gaan vervullen, waarvoor hij opgeleid moet worden, maar zal ook merken dat zijn beroep veel meer inhoud heeft gekregen. Dit alles vraagt om langdutige contracten, zowel uit de zlenswijze van de vrijwilliger als werknemer als uit de zienswijze van de krijgsmacht als werkgever. ${ }^{5}$

\footnotetext{
4Matschappelijke Raad voor de Krijgsmacht, Contractduur, advies 24, Den Haag, 1992, blz. 2.

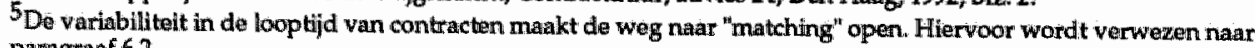
paragraaf 6.2.
} 
Samenvattend kunnen we ten aanzien van de contractduur stellen dat langdurige contracten leiden tot een groter aanbod van vrijwilligers, mits de contracten voldoende inhoud hebben. Inhoud die verkregen kan worden door de uitbreiding van het takenpakket van een militair. ${ }^{6}$

Een baan in de krijgsmacht is altijd geassocieerd met avontuur. Bij gebrek aan echte actie is flink geromantiseerd over het avontuurlijke karakter van de krijgsmacht, omdat het avontuurlijke karakter een positief effect op het aanbod van vrijwilligers had. Door de veranderde taken van de krijgsmacht zal het avontuurlijke karakter van de krijgsmacht in een ander daglicht moeten worden gesteld.

Een baan in de krijgsmacht is niet altijd zo mooi, omdat de kans dat een soldaat slachtoffer wordt bij een actie door de veranderde taken danig toeneemt. Daarom moeten we ook de keerzijde van het avontuur beschouwen. Wat is de kans dat een soldaat lichamelijk letstel oploopt bij een actie? In het verleden was deze kans niet zo groot, omdat de dreiging voorop stond en riet de inzet van troepen. Over het algemeen had een soldaat toch het idee dat het militaire beroep gevaarlijk was. Maar indien de krijgsmacht nader onder de loep wordt genomen, blijkt dat echter mee te vallen. Doden en gewonden zijn geconcentreerd in een beperkt gedeelte van de krijgsmacht: piloten en bepaalde delen van brigades. Bovendien blijkt uit het werk van Steven L. Canby ${ }^{7}$ dat de doden en gewonden vooral te betreuren zijn onder de nieuwkomers binnen de krijgsmacht. Professionele militairen ontsnappen veelal aan het levensrisico. Canby stelt zelfs:

"Peacetime risk of life is now probably lower in the military than in civilian life. (w....) An individual volunteering for a professional career in peacetime does not unduly increase his chances of dying, since (1) the peacetime incidence is no higher than the civilian average; (2) $87 \%$ are able to volunteer for the noncombat arms ${ }^{8}$ and (3) his risk is mainly in being assigned a combat leadership position in wartirne".

Door de veranderingen in de wereld zijn de taken van de krïgsmacht veranderd en zo ook het levensrisico, omdat nu veel meer dan voorheen troepen ook daadwerkelijk zullen worden ingezet. Hoe het levensrisico binnen de krijgsmacht door de verschillende militairen geïnterpreteerd wordt, hangt van de militairen zelf af. Sommige militairen zullen een hoge risicoaversie hebben en zullen niet bereid zijn zich voor gevaarlijke opdrachten in te zetten. Anderen hebben daarentegen niet zo' $n$ hoge risicoaversie en zijn daarom bereid verder te gaan bij de aanvaarding van risicovolle taken.

Risicoaversie is een subjectief element en onderdeel van de voorkeuren van potentiële vrijwilligers. Door de verschillende gradaties in risico, zowel in taken bij de krijgsmacht als in de voorkeuren van de vrijwilligers, moet het ook hier mogelijk zijn een "matching" van wensen tot stand te brengen. ${ }^{9}$ Naarmate het risico van de taken toeneemt, en het avontuur afneemt, zal het aanbod van vrijwilligers afnemen. Het aanbod van vrijwilligers zal ook afnemen indien de gemiddelde risico-aversile van de individuele militairen toeneemt.

\footnotetext{
GIn paragraaf 6.4. zal uitgebreid aandacht worden besteed aan de mogelijklheden er voor te zorgen dat langdurige contracten daadwerkelijk uitgediend worden of dat contracten verlengd worden.

7 Steven L. Canby, Military Manpower Procurement, i Policy Analysis, Lexington, 1972, bli. 65.

8 Dit geeft nogmaals aan welke mogelijkheden er liggen voor burgers in de krijgsmacht.

${ }^{9}$ Het lewensrisico of de kans te sterven heeft niet alleen invloed op de bereidheid van poteriticle vrijwilligers zich aan te bleden aan de krijgsmacht. De relatie geldt ook andersom. De structuur wan de krijgsmacht heeft wok in vloed op de mate van risico die vrij.willigers eventueel zullen lopen. In paragraaf 6.4. zal worden uiteen gezet dat het levensrisico van vrijwilligers in een vrijwilligersleger anders is dan het levensrisico van dierwitplichtigen in een dienstplichtigenleger.
} 
Van de secundaire arbeidsvoorwaarden gaat een positief effect uit op het aanbod van vrijwilligers. Voor een potentielle vrijwilliger is van de secundaire arbeidsvoorwaarden de opleidingscomponent de belangrijkste. Door dienst te nemen in de krijgsmacht kan een vrijwilliger in zijn bestaansbehoeften voorzien. Doch dit kan afgelopen zijn indien zijn contract afloopt. Om na zijn diensttijd zo snel mogelijk aan het werk te komen is het noodzakelijk dat hij of zij op een baan in de burgermaatschappij voorbereid is. Hiervoor is scholing noodzakelijk.

De krijgsmacht kan in deze behoefte aan "human capital" voorzien door tijdens de diensttijd de vrijwilliger op te leiden voor een baan in de burgermaatschappij. Dit is niet alleen in het belang van de vrijwilliger, maar ook in het belang van de krijgsmacht. Door de invoering van een leerlingwezen in de krijgsmacht ontwangt een vrijwiligger toekomstig inkomen in de vorm van "human capital" en krijgt de krijgsmacht de beschilkking over" geschoolde krachten, die zij kan gebruiken voor specifieke activiteiten op het gebied van humanitaire hulpverlening; ${ }^{10}$ Gedurende zijn diensttijd wordt een militair opgeleid voor een burgerfunctie. Het contract van de militair kent dan ook twee perioden. Bij een zes-jarig dienstverband wordt vijf jaar militaire dienst gecombineerd met een civiele opleiding, met in het zesde jaar de afronding van de studie, inclusief een stageperiode van ongeveer een half jaar. Bij de stage kan gedacht worden aan burgerfuncties binnen en buiten de krijgsmacht.

Bij dit scholingsproces is het belangrijk dat de burgeropleiding een integraal deel uitmaakt van de diensttijd en niet na diensttijd wordt verricht. Indien de opleiding niet in diensttijd wordt verricht loopt de krijgsmacht namelijk het risico zonder voldoende geschoolde krachten te komen zitten, waardoor zij zich zelf in de vingers snijdt, omdat zij haar humanitaire taken dan niet kan uitvoeren. Toekomstig inkomen heeft een positief effect op het aanbod van vrijwilligers, hoewel het exacte effect voor iedere vrijwilliger verschillend zal zijn.

Eerder in dit hoofdstuk hebben we reeds gezien dat slechte arbeidsomstandigheden een negatief effect hebben op het aanbod van vrijwilligers. De krijgsmacht verschuilt zich bij de arbeidsomstandigheden vaak achter het feit dat het werken in de krijgsmacht nu eenmaal zwaar en smerig werk met zich mee brengt, dat onder de meest ongewone omstandigheden uitgevoerd moet worden.

Deels heeft zij daarin gelijk en dat is de werknemers in de krijgsmacht ook bekend. Maar het is heel wat anders als de maatstaven van de krijgsmacht in oorlogstijd ook worden toegepast in vredestijd. In vredestijd gelden andere normen en waarden dan in oorlogstijd, ondanks het feit dat in vredestijd geoefend moet worden om te kunnen optreden in een oorlog. In vredestijd staat de produktie van gevechtskracht voorop en niet de oorlog op zich.

In viredestijd dienen de normen en waarden van de burgermaatschappij te gelden, waarbij de werknemers voorbereid zijn op de arbeidsomstandigheden tijdens een oorlogstijd. Het strikt doorvoeren van de oorlogsomstandigheden in vredestijd leidt tot een onnodig afschrikken van potentiële vrijwilligers, zeker indien deze slechte arbeidsomstandigheden ook op de kazernes aanwezig zijn. Juist op de kazemes is er geen enkele redlen af te wijken van wat in de burgermaatschappij normaal is. Dit betekent een normale huisvesting, een normale werkweek, normale arbeidsverhoudingen die niet gebaseerd zijn op rang maar op functie, normaal eten en normale omgangsvormen. De slechte arbeidsomstandigheden, zoalls verveling, die het gevolg zijn van de misallocatie door de dienstplicht dienen daarbij niet vergeten te worden in

10 Ook hier mijn diverse opties atan te brengen, waardoor het "matching" -principe in beeld komt. Zie paragraaf 62. 
deze professionele krijgsmacht. ${ }^{11}$ Op plaatsen waar de krijgsmacht een grote achterstand heeft op de burgermaatschappij is onmiddellike actie geboden, omdat slechte arbeidsomstandigheden de krijgsmacht enorm kunnen schaden in het verkrijgen van het juiste personeel. De verhouding (A/BW) zal op de kazerne minstens 1 moeten zijn en tijdens oefeningen zal zij de 1 zoveel mogelijk moeten benaderen, hoe moeilijk dat laatste misschien ook is.

Zoals in iedere arbeidsmarkttheorie speelt de bestaande werkloosheid een rol bij het aanbod van vrijwilligers. Tot op zekere hoogte zullen vrijwilligers hun reserveringsloon naar beneden bijstellen, indien ze niet snel aan het werk kunnen komen. Daarnaast zal de krijgsmacht een alternatief gaan vormen voor mensen die langdurig werkloos zijn, indien het werk in de krijgsmacht gecombineerd wordt met burgeropleidingen.

Grotere werkloosheid, zowel in omvang als in duur, zal leiden tot een groter aanbod van vrijwilligers. Echter de exacte grootte van het extra aanbod moet niet overschat worden. De krijgsmacht zal moeten blijven concurreren met de burgermatschappij, want indien de beloften van de krijgsmacht niet overeenkomen met de verwachtingen van de vrijwilliger, zal deze vrijwilliger er toch nog een keer over nadenken of hij zijn zoekproces well of niet voortzet. Zelfs bij toegenomen werkloosheid. Een belangrijk aspect bij het zoekproces is natuurlijk de allernatieve opbrengst van het doorgaan met zoeken. Daarbij speelt niet alleen het toekomstige loon van een betere baan een rol, maar juist ook de hoogte van de huidige uitkering of het huidige arbeidsinkomen. Indien een baan in de krijgsmacht materieel en immaterieel onvol doende oplevert ten opzichte van het huidige inkomen zal het zoekproces worden doorgezet. De materiële opbrengst in de krijgsmacht is vaak voldoende, doch de immateriële opbrengsten zijn vaak negatief waardoor het reserveringsloon niet bereikt wordt.

Ten opzichte van het bedrijfsleven heeft de krijgsmacht als voordeel dat zij vrij conjunctuurongevoelig kan handelen. Indien in tijden van laagconjunctuur de krijgsmacht met een "aansprekend aanbod"12 komt zal de belangstelling voor een baan zeer groot zijn. Waar kan een werkloze anders naar toe?

Informatie is het laatste element dat hier besproken wordt. Bij de eilandentheorie van Phelps hebben we al gezien dat het bestaan van imperfecte informatie leidt tot een zoekproces. Naarmate een potentiële vrijwilliger beschikt over perfectere informatie zal hij weten op welk eiland hij het hoogste loon kan vinden. Zijn zoekproces zal worden verkort en zijn "opportunity costs" nemen daardoor af.

Uit de eilandentheorie volgt dat het aanbod van vrijwilligers in een bepaalde sector toeneemt naarmate het informatieaanbod toeneemt. Het opvoeren van wervings. inspanningen kost echter ook geld. Het is daarom belangrijk dat de informatie zo compleet mogelijk is tegen zo min mogelijk kosten. Concluderend kunnen we stellen dat met het toenemen van de werfinspanningen het aanbod van vrijwilligers toeneemt, onder de randvoorwaarde dat de wervingsinspanningen effectief en efficiënt zijn.

In deze paragraaf hebben we de theorie van het arbeidsaanbod onder de loep genomen. Het blijkt dat een groot aantal elementen hierbij een rol spelen. Vele elemen.

\footnotetext{
11 Zie hoofdstuk 5 , paragraf 2.

12 Zie hierwoor ook het arbeldsmarktonderzoek ten behoeve van de Commissie-dienstplicht 1992. "Nanr dibnstplicht nietawe stij", Den Haag, 1992, onderdeel onderzoek arbeidsmarkt cn kadervrijwilliggerskrijgsmacht, blz. 34 .
} 
ten, zoals opleiding, contractdurur en risico-aversie kunnen gecombineerd worden, indien we deze elementen spiegelen aan de taken van de krijgsinacht. De wensen wan de vrijwilliger en de behoeften van de krijgsmacht blijken op vele mogelijke manieren in elkaar te passen. Ze "matchen". Deze matching kan de basis zijn voor een contract. tussen vrifwilliger en krijgsmacht.

Goed beschouwd is er naast het gewone geschreven contract ook sprake van een ongeschreven contract tussen wrijwilliger en krijgsmacht. Uit dit ongeschreven contract kan de echte waarde blijken wan een baan in de krijgsmacht. De krijgsmacht heeft zich in dit contract verplicht de vrijwilliger te respecteren als een persoon, de vrijwilliger nuttig werk te geven en de mogelijkheid tot individuele ontplooiing volledig tot uiting te laten komen. De vrijwilliger heeft zich in het ongeschreven contract verplicht tot het zo goed mogelijk witoefenen van zijn taak en gedisciplineerd gedrag. Bliven ${ }^{13}$ vindt de twee contracten:

\begin{abstract}
"A reasonable bargain. My rough guess is that two-third of the new man at Ord ${ }^{14}$ are after remedial education or a skill that they can transfer at some later date to a civilian occupation. The idea that they are looking for 'permissiveness'- by that I mean toleration of their failures to meet established military standards- is completely wrong. It is the ather way around: They want a vigorous, challenging program. The worst thing we could do is fail to give it to them".
\end{abstract}

Matching kan zorgen voor een maatpak voor de krijgsmacht. Dit maatpak is het onderwerp van de volgende paragraaf.

\title{
\$ 6.2. Nederland en de uitwoering van VN-taken: een maatpak voor de krijgsmacht
}

De Nederlandse krijgsmacht heeft er een hoofdtaak bijgekregen. Inzet van troepen in VN-verband zal in de toekomst eén van de belangrijkste taken van de Nederlandse krijgsmacht worden. Deze inzet van troepen zal voornamelijk geschieden buiten het Navo-verdragsgebied. Voor deze inzet zijn militairen nodig die in hoge mate voorbereid zijn voor dit werk en ook daadwerkelijk ingezet kunnen worden. De geschiktheid van de Nederlandse soldaat, de dienstplichtige, is echter afgenomen. Dit komt ondermeer door de voortgaande verkorting van de dienstplichtperiode tot een jaar. ${ }^{15}$ De periode van een jaar is tekort om een dienstplichtige adequaat op te leiden en in te zetten voor VN-taken. De investeringen in de dienstplichtigen zijn te groot om deze investeringen gedurende de diensttijd van de dienstplichtige terug te verdienen. De verkorting van de diensttijd is de uitkomst van een publiek besluitvormingsproces, welke niet meer terug te draaien is. Bovendien is besloten dat voor operaties buiten het Navo-verdragsgebied de toestemming van de dienstplichtige noodzakelijk is. Zonder medewerking wan de dienstplichtigen zijn VN-operaties feitelijk niet mogelijk.

In deze paragraaf zal worden beschreven hoe de Nederlandse krijgsmacht haar organisatie zal moeten veranderen om tot een effectieve en efficiënte uitvoeringsorganisatie te komen die kan voldoen aan de aan haar opgedragen hoofdtaken en daarbij tevens kan voldoen aan de wensen van de vrijwilligers die de krijgsmacht zullen moeten vullen bij de afwezigheid van dienstplichtigen.

\footnotetext{
13 Bruce Jr. Bliwen, Volunteers, one and all, New York, 1962, bllz.133.

${ }_{14}$ Fort Ord is een legerbaasis in de Verenigde Staten.

15 per 1 januari 1994 is de diensttijd verder verkort tot 9 manden.
} 
Voortkomend uit de internationale veiligheidssituatie en het publieke besluitvormingsproces heeft de krijgsmacht drie soorten hoofdtaken:16 1 . Verdediging van de "landsgrenzen" in Navo-verband en "VN-peace-enforcing" operaties. Dit zijn operaties waarbij gebruik wordt gemaakt van gewell. 2. "VN-peace-keeping" operaties en 3. intemationale humanitaire dienstverlening. Deze laatste twee taken worden uitgevoerd zonder het gebruik van geweld. ${ }^{17}$ Deze taken zullen zich moeten spiegelen in de organisatie van de krijgsmacht. Met de krijgsmacht wordt in het algemeen de Koninklijke Landmacht, de Koninklijke Luchtmacht en de Koninklijke Marine bedoeld. In het vervolg van deze paragraaf zal met de krijgsmacht voornamelijk de Koninklijke Landmacht worden bedoeld. Daar waar deze paragraaf specifiek ook van belang is voor de Koninklijke Marine en de Koninklijke Luchtmacht zal dit nader vermeld worden.

Met betrekking tot de organisatie van de krijgsmacht zal worden uitgegaan van een geintegreerde organisatie. Dat wil zeggen dat de drie thoofdtaken niet door aparte onderdelen uitgevoerd zullen worden, maar dat leder onderdeel en ledere militair in principe drie taken heeft. Taken die voortvloeien uit de hoofdtaken van de krijgsmacht.

De militair in deze organisatie zal een beroepsmilitair moeten zijn, omdat alleen beroepsmilitairen alle drie de taken naar behoren zullen kunnen uitvoeren. Dienstplichtigen kunnen niet tegen hun wil worden uitgezonden voor "out-of-area" operaties.

Strikt gezien zouden de "VN-peace-keeping" taken en de humanitaire taken ook door burgers kunnen worden uitgevoerd, omdat aan deze taken geen geweldselement gekoppeld is, doch door de integratie van de drie taken in de operationele onderdelen van de Koninklijke Landmacht is dit uitgesloten. Het is wel mogelijk burgers in te zetten voor eventuele niet-geintegreerde taken.

De structuur van de organisatie komt verder aan de orde in paragraaf 6.2.1. De taken van ieder deel in de organisatie worden in paragraaf 6.2.2. behandeld. Paragraaf 6.2.3. gaat in op de opleiding van de beroepsmilitairen en paragraaf 6.2.4. op de werving van deze militairen. De conclusies tenslotte volgen in paragraaf 6.2.5.

\section{§ 6.2.1. De organisatiestructuur}

Figuur 6.1. geeft een beeld van de organisatiestructuur van de toekomstige Koninklijke Landmacht. De tweedeling in de organisatie is gebaseerd op het onderscheid tussen geweldsfuncties en niet-geweldsfuncties. ${ }^{18}$

\footnotetext{
$16 \mathrm{MRK}$-advies nr.25: Intemationallsering van de krijgsmacht, Den Haag 1992, blu, 61.

17 Met dien werstande dat het gebrilk van geweld ter zelfverdediging hier ook onder valk.

18 Zie ook hooflistuk 2 , paragraaf 2.
} 
Pugurur 6.1. Organisatiestructuur Koninklijke Landmacht.

\begin{tabular}{|c|c|}
\hline $\begin{array}{l}\text { Taken: } \\
\text { Verdedigen van de landsgrenzen } \\
\text { (Navo-taak, VN-peace-enforcing) }\end{array}$ & $\begin{array}{l}\text { Taken: } \\
\text { VN-Peace-keeping en humanitaire } \\
\text { hulp }\end{array}$ \\
\hline Landmacht-structuur & VN-vredesmacht eenheden \\
\hline $\begin{array}{l}\text { - Intendance (B) } \\
\text { - Geneeskundig (B) } \\
\text { - Cavalerie (A) }\end{array}$ & $\begin{array}{l}\text { Humanitaire taken } \\
\text { A - technisch } \\
\text { B - dienstverlenend }\end{array}$ \\
\hline - Artillerie (A) & \\
\hline - Genie (A) & C Peace-keeping \\
\hline - Pantserinfanterie ${ }^{19}(A+C)$ & DSpecialisten-team \\
\hline - Verbindingen $(A+C)$ & \\
\hline
\end{tabular}

Uit figuur 6.1. volgt dat militairen of eenheden die primair in een landmachtstructuur zijn ondergebracht, "gematched" worden aan bepaalde VN-taken. Deze taken kunnen humanitair (technisch of dienstverlenend) of "peace-keeping" zijn. Zo zullen geneeskundige troepen zich naast hun Navo-taak moeten bezig houden met humanitaire dienstverlening en is de pantserinfanterie voorbestemd voor "peace-keeping" activiteiten en technische humanitaire taken. De hier genoemde voorbeelden vormen een indicatie, doch zullen flexibel geïnterpreteerd dienen te worden. ${ }^{20}$

Voor specialistische krachten die niet aanwezig zijn in de landmachtstructuur, kan geworven worden onder de burgerbevolking volgens het "Noordse"-systeem. Dit systeem zall worden uitgelegd in paragraaf 6.2.4. Specialisten komen als burger in de organisatie en blijven burger omdat zij slechts een taak hebben aan de rechter-en nietgeweldskant van de organisatie.

In figuur 6.1. is een duidelijk onderscheid gemaakt tussen "peace-enforcing" enerzijds, en "peace-keeping" en humanitaire hulp anderzijds. "Peace-keeping" en humanitaire hulp liggen in elkaars verlengde en de twee taken kunnen vrij gemakkelijk zonder juridische belemmeringen in elkaar overgaan.

Met "peace-enforcing" en "peace-keeping" is dit anders. Hoewel het theoretisch mogelijk is dat "peace-keeping" overgaat in "peace-enforcing" is dit praktisch vrijwel ondenkbaar. "Peace-keeping" eenheden zijn losse eenheden, veelal bezig met een specifieke takk. Willen deze eenheden vrede opleggen dan is gecombineerde actie noodzakelijk en de meest effectieve structuur om dit te doen is de landmachtstructuur. Een "peace-keeping" eenheid beschikt over het algemeen niet over de juiste combinatie van kapitaal en arbeid om die gevechtskracht voort te brengen die voor "peace-enforcing" noodzakelijk is. "Peace-enforcing" vanuit een "peace-keeping" eenheid betekent eerder zelfvernietiging en is zodoende niet effectief. Iedere politieke druk om als een "peace-keeping" eenheid deel te nemen aan "peaceenforcing" aktiviteiten moet dan ook als onaanvaardbaar van de hand worden gewezen.

\footnotetext{
19 Aangevuld met mariniers uit de Koninklijke Marine.

20Daarom is de linkerzijde van figurir 6.1. wellicht niet uitputtend genoeg opgesomd.
} 
De taken aan de linkerkant van figuur 6.1. zijn reeds vele jaren bekend. Deze Navotaken welke gemakkelijk kunnen worden omgezet in "VN-peace-enforcing" taken blijven dezelfde. Hier zal niet verder op worden ingegaan.

Taken die toebehoren aan een "VN-peace-keeping" eenheid kumnen in het algemeen worden samengevat onder de volgende kopjes:"21

(a) Toezichthouden op een wapenstilstand of afspraak daar over.

(b) Het voorkomen van een gewapend conflict tussen naties of binnen een natie.

(c) Bij te dragen aan de handhaving van het recht en een terugkeer naar de normale voorwaarden van een rechtsstaat.

Toegevoegd aan deze taken kunnen "peace-keeping" eenheden ook ingezet worden voor taken als het toezicht op vluchtelingen, bescherming van humanitaire hulpacties, gevangenenruill enz.

De humanitaire eenheden hebben tot taak hulpprogramma's uit te voeren. De hulpprogramma"s kunnen ondermeer het reactiveren van functies binnen de overheidsorganisaties, het herstellen van verwoeste huizen, geneeskundige verzorging, voedselvoorziening enz. inhouden. Birnen de humanitaire eenheden zijn twee takken te onderscheiden. Eên tak die zich voornamelijk met mensen bezighoudt en de dienstverlenende tak wordt genoemd en de tweedle tak die zich met technische zaken bezighoudt. Het technische team is een organisatie bestaande uit technische projectmanagers en assistenten van verschillende achtergrond tezamen met administratief personeel. De taken van het team zijn herstel en tot op zekere hoogte de herbouw van verwoeste of beschadigde installaties, openbare gebouwen, verblijfsruimten enz.

Het werk van het team houdt in:

(a) woningbouw

(b) aanleggen electriciteit

(c) wegwerken, water- en drainageprojecten

(d) telecommunicatie

(e) verwarming, ventilatie en sanitair.

Tenslotte zijn er de specialistische taken. Voor deze taken zijn mensen noodzakelijk die bepaalde specifieke kennis of vaardigheden hebben, welke in de landmachtstructuur niet voorhanden of niet nodig is. Het opzetten van een VN-eenheid komt vaak organiek niet geheel overeen met de oorlogsformatie van de Koninklijke Landmacht.

De VN-basisorganisatie zal door de toevoeging van de extra specialisten flexibeler in structuur worden en kan zodoende worden aangepast aan de aard van de taak. Juist door de additionele deelname van het specialistenteam kan een eenheid zonder problemen "op maat" worden gemaakt voor een toekomstige rol binnen een VN-vredesmachtoperatie.

\section{\$6.2.3. Opleiding}

Iedere militair heeft drie taken. Voor dêze taken dient hij of ziji ook opgeleid te worden. Voor zijn of haar Navo-taak zal de opleiding weinig afwijken van de huidige militaire opleiding. Voor de VN-taken is wel een nieuwe opleiding nodig. Om in VN-

21 Bron: Nordic Stand-by Forces in United Nations service, NorBerFN, Stockholm, 1974, blz. 45. 
operationeel gebied volledig uit de voeten te kunnen zijn extra vaardigheden noodzakelijk. In het algemeen kunuen de volgende trainingsdoelen hieraan bijdragen:

(a) kernis van de VN-operatie en het opereren in een vredesmacht en de voorwaarden die deelname in VN-verband inhouden.

(b) kennis van de klimatologische omstandigheden en topografische voorwaardlen in gebiedien waar VN-diensten uitgevoerd kunnen worden en de vragen die dit eventueel oproept.

(c) Een adequate bekwaamheid in het uitoefenen van de taken - binnen het raamwerk van de VN - die toegewezen worden aan de eenheid of individu onmiddellijk na aankomst in het VN-missie gebied.

De opleidingen ten behoeve van de VN-taken zullen de krijgsmacht dus een internationale orièntatie moeten bijbrengen. Dit vraagt ondermeer om taalonderwijs en. aandacht voor managementvaardigheden in international verband. De toekomstige militair zal in zijn opleidingsfase een mentaliteit moeten verwerven voor het uitoefenen van zijn takk die gericht is op bemiddeling, verzoening en onderhandeling.

Een goede voorbereiding inzake de politieke, geografische, culturele, religieuze en taalkundige situatie van een land waarheen de witzending hoogstwaarschijnlijk zal gebeuren is bijzonder gewenst. De opleiding zal zich daarbij voortdurend moeten aanpassen aan de resultaten van de per specifieke situatie verschillende probleemanalyses.

Voor de humanitaire taken is een gedegen civiele opleiding noodzakelijk. Een opleiding die verzorgd zal moeten worden door de krijgsmacht.22 Zoals we gezien hebben bij de bespreking van de secundaire arbeidsvoorwaarden in paragraaf 6.1. gaat van zo'n opleiding tevens een positieve impuls uit naar de aantrekkelijkheid van het militaire beroep.

De verschillende behoeften en opleidingen zullen gecoördineerd kunnen worden door een VN-instituut, zoals reeds bestaat in Zweden. Zij kan ook de informatieverschaffing ten behoeve van een juiste opleiding van VN-militairen op zich nemen. Bij de gedachten over een VN-institutut kan aansluiting worden gezocht bij de United Nations University in Tokio, en haar internationale netwerk. Daarbij kan ook worden geleerd van de ervaring die in de Scandinavische landen is opgedaan met opleidingen voor VN-taken.

De specifieke VN-opleiding voor de specialisten, waarin ze de algemene doelen en vereisten duidelijk wordt gemaakt, zal ongeveer 4 weken duren. De specifieke kennis waarvoor zij aangenomen zijn, wordt meegenomen uit de burgermaa tschappij.

\section{\$6.2.4. Werving en matching}

Uit het voorgaande is gebleken dat militairen in de krijgsmacht te maken hebben met verschillende taken. De diverse taken brengen verschillende risicograden met zich mee en voor de diverse taken zijn ook verschillende opleidingen nodig. De werving van personeel voor deze taken dient hierop afgestemd te zijn.

ledere beroepsmilitair heeft in principe drie taken en zal dus evenveel opleidingen dienen te krijgen. Voor de humanitaire taak is het noodzakelijk dat een militair een goedle burgeropleiding krijgt. Deze burgeropleiding zall zo goed mogelijk moeten aansluiten bij de behoeften in de burgermaatschappij, zodat een militair na zijn diensttijd nog veel plezier beleeft aan zijn humanitaire taak. Door bepaalde

22 In de praktijk bettekent dit de inwoering van het leerlingwezen binnen de krijgsmacht. 
eenheden voor te bestemmen aan bepaalde VN-eenheden kan bij de werving selectief gewerkt worden en kan zo goed mogelijk worden voldaan aan de opleidingswensen van de militair.

Bij de werving zal ook rekening moeten worden gehouden met de verschillende risico-aversies die mensen hebben. Voor de animo zich als vrijwilliger aan te melden is van groot belang hoe groot de kans is dat militairen in levensbedreigende situaties kunnen komen te verkeren. Des te groter deze kans, des te minder vrijwilligers zich zullen aanmelden.

De taken binnen de organisatie hebben ook een bepaald risico-karakter. Door mensen met een lage risico-aversie te "matchen" aan taken met een hoger risico, en mensen met een hoge risico-aversie te "matchen" aan lage risico taken kan een betere afstemming worden gemaakt tussen de behoeften van de organisatie en de wensen van de militair. Risico-differentiatie heeft voornamelijk te maken met de taken aan de rechterkant van figuur 6.1., daar er relatief veel "peace-keeping" en humanitaire operaties voorkomen met een verschillende sterftekans. Het totale risico kan daarom verschillen van vrijwel nul tot een aanzienlijk risico. De linkerkant van figuur 6.1, "peace-enforcing", kent weliswaar een hogere sterftekans per gebeurtenis, maar de kans op zo'n gebeurtenis is niet zo groot, waardoor het algemene risico niet zo hoog ligt. ${ }^{23}$

Concreet betekent dit dat een vrijwilliger kiest voor een baan met een hoog of een laag risico en krijgt hij of zij een civiele opleiding die afgestemd is op de wensen van de militair en de behoefte van de krijgsmacht. De duur van het contract zal moeten worden afgestemd op de inhoud van het contract. Daarnaast zal ook de beloning gedifferentieerd moeten plaatsvinden. Hogere beloningen voor banen met een hoger risico en langere contracten. ${ }^{24}$

Indien de behoeften van de krijgsmacht niet goed aansluiten bij de wensen van de militairen zal eerst gekeken moeten worden of de krijgsmacht zich zo flexibel kan opstellen dat wel voldaan kan worden aan de wensen van de militair. Blijkt dit niet mogelijk te zijn dan zall de krijgsmacht met behulp van schaarstepremies de voorkeuren van de militairen moeten beinvloeden. Differentiatie in wensen met betrekking tot taken, burgeropleiding en risico-aversie zal gesteund moeten worden door differentiële beloning. ${ }^{25}$

Om de juiste mensen op de juiste plaats te krijgen, zonder dat er veel mensen op eén of andere manier zullen afvallen, is het noodzakelijk dat potentiële vrijwilligers zodanig worden voorgelicht dat zij een goede afweging kunnen maken tussen de voor- en nadelen van een baan in de krijgsmacht. Zij dienen een reële inschatting van de consequenties van hun beslissing te kunnen maken. Vrijwilligers hebben te allen tijde recht op gedegen informatie over hun rechtspositie, betaling en de omstandigheden waarmee ze te maken krijgen of kunnen krijgen. De grootte van het risico dient hen altijd duidelijk te zijn. Slechts op basis van volledige informatie kan een vrijwilliger instemmen met zijn contract. Blijkt na tekening van het contract dat er duidelijk sprake is van een nieuw feit, dan moet er ook ruimte zijn dit contract te ontbinden.

\footnotetext{
23 Een woombeld wan zoin gebeurteris is de Golfoorllog.

24 In paragraaf 6.4 van dit hoofdstuk zal nader worden ingegaan op de koppeling van salaris aan lengte wan het contract, risico-aversie, schaarstie enz.

25 In de praktijk betekent dit dat de salarisstructuur losgekoppeld dient te worden van de rangsstructuir. Als woorbeeld kan hier gediacht worden aan het salaris van pen pantserinfanterist met een zos-jarig contract en de rang soldaat. Dit kan hoger liggen dan het salaris van een luitenant bij die intendance, indien blijkt dat luitenants bij de intendance gemaikkelijk te krijgen zijn op de arbeidsmarkt, terwijl soldaten voor de pantigerinfanterie veel moeilijker voorhanden zijn. Zie verder paragraat 6.4.
} 
De werving van de specialisten is een probleem van een andere orde. Dit probleem kan worden opgelost met het systeem dat in de Scandinavische landen en Finland gebruikt wordt. Birnen het "Noordse"-systeem wordt personeel geselecteerd op basis van vrijwillitgheid en nawwkeurige screening. In het geval van vrijwillige aanmelding door een dienstplichtige wordt in Zweden bovendien de eis gesteld dat de eerste oefening van de militaire dienst vervuld is. Afspraken voor het specialistenteam worden per contract opgemaakt en dit contract wordt getekend bij toetreden. De lengte van de dienst is ongeveer een jaar en houdt in dat vrijwilligers zich opgeven voor een specifieke $\mathrm{VN}$-training en zich daarna gedurende een "stand-by" periode gereed houden. Gedurende de "stand-by" periode is de specialist niet gebonden, maar is hij wel verplicht binnen een aantal dagen gereed te zijn om voor dienst in VN-verband te worden uitgezonden voor een periode van ongeveer 6 maanden. In het contract zal de salariezring en de duur van de verbintenis in termen van beschikbaarheid en maximale uitzendtermijn vastgelegd moeten worden. De financiële vergoeding dient compensatie te bieden voor zowel de beschikbaarheidstermijn als de uitzending. Daar komt bij dat het terugkeren naar de oude werkkring na dienstvervulling in VN-verband geen enkel probleem met zich mag meebrengen. Eén en ander zal met wettelijke maatregelen moeten worden ondersteund. Om de arbeidspool voortdurend bezet te houden dient ieder jaar opnieuw geworven te worden onder de burgerbevolking.

In deze paragraaf zijn we uitgegaan van een vrijwilligersleger. In een vrijwilligersleger is het "Noordse"-systeem slechts noodzakelijk voor de specialisten, omdat de uitvoering van de overige taken van de krijgsmacht zonder problemen kan worden overgelaten aan de vrijwillige beroepsmilitairen. In een dienstplichtigenleger zall voor de taken aan de rechterkant wan de organisatie wel geworven moeten worden volgens het "Noordse"-systeem, omdat dit systeem feitelijk het enige systeem is om in een dienstplichtigenleger uitzendingen in VN-verband te regelen zonder juridische en organisatorische belemmeringen. De ervaringen van een land als Zweden met haar vele uitzendingen naar ondermeer Cyprus, Libanon, Nigeria enz. heeft het succes van deze formule reeds vele tientallen jaren aangetoond. Dit betekent wel dat er twee organisaties naast elkaar zullen bestaan aangezien de linker-en rechterkant van de organisatie, zoals weergegeven in figuur 6.1., niet uitwisselbaar zijn. De kosten van de krijgsmacht zullen als gevolg van deze dubbele uitvoeringsorganisatie dan ook navenant toenemen. Het "Noordse"-systeem is zeker effectief doch kan qua doelmatigheid worden verbeterd. Dit laatste hangt samen met de keuze voor een dienstplichtigenleger of een vrijwilligersleger.

\section{\$6.2.5. Conclusies}

In deze paragraaf is uiteengezet hoe een adequate uitvoeringsorganisatie voor de toekomstige taken van de krijgsmacht en dan met name de Konirklijke Landmacht er uit zal moeten zien wil deze effectief en efficiënt kunnen werken en kunnen aansluiten bij de wensen van potentièle vrijwilligers. Uit deze paragraaf blijkt dat:

(a) Alleen vrijwilligers, c.q beroepsmilitairen geschikt zijn voor de gehele organisatie. Dit wil niet zeggen dat dienstplichtigen ongeschikt zouden zijn, maar duidt erop dat in een dienstplichtigenleger geen geîntegreerde organisatiestructuur mogelijk is. In een vrijwilligersleger is geen dubbele organisatie nodig om de Navo en VN-taken te kunnen uitvoeren. Bovendien kunnen de investeringen in dienstplichtigen om deze 
geschikt te maken voor de nieuwe VN-taken zeer moeilijk worden terugverdiend in de tijd dat de dienstplichtigen in de krijgsmacht aanwezig zijn. Om de geïntegreerde organisatiestructuur te realiseren zal de Nederlandse krijgsmacht moeten worden ongebouwd tot een vrijwilligersleger.

(b) De organisatie integraal taken uitvoert die liggen op het gebied van enerzijds de traditionele Navo-taken en "peace-enforcing" en anderzijds "peace-keeping" en humanitaire doelen.

(c) Iedere militair drie opleidingen krijgt, waarbij de civiele opleiding, de humanitaire VN-opleiding en de persoonlijke wensen van de militair zoveel mogelijk op elkaar afgestemd dienen te zijn. Daarbij moet de civiele opleiding voor een goede aansluiting zorgen bij de latere overgang naar de burgermaatschappij.

(d) Werving van militairen afgestemd zal moeten zijn op de wensen qua opleiding, risico-profiel en contractduur van de toekomstige militair. Dit wordt ondermeer bereikt door eenheden uit de oorlogsorganisatie (linkerzijde figuur 6.1.) te "matchen" aan $\mathrm{VN}$-eenheden (rechterzijde figuur 6.1.). Differentiatie in taken en wensen is daarbij gekoppeld aan differentiatie in beloning.

(e) Er overgegaan zal moeten worden tot de oprichting van een $\mathrm{VN}$-instituut ter coörtdinatie van velerlei taken, behoeften en opleidingen op VN-gebied. Daarbij is aansluiting bij het bestaande internationale netwerk op dit gebied nadrukkelijk gewenst.

(f) Er een arbeidspool van specialisten voor VN-taken zal moeten worden opgericht.

\section{§6.3. Het wervings- en selectieproces}

De werving van personeel behoort tot de essentiële pijlers van een vrijwilligersleger. Gedurende de tijd van een dienstplichtigenleger heeft een werver een passieve taak. Tekorten aan beroepspersoneel kunnen in noodgevallen altijd worden opgevangen door tijdelijk extra dienstplichtigen in dienst te nemen. In een vrijwilligersleger dient de werver een actieve inspanning te leveren, omdat het aanbod van militairen niet meer oneindig is.

In een vrijwilligersleger is het aanbod van vrijwilligers in eerste instantie nul en zal pas van de grond komen indien er wervingsinspanningen worden verricht. Het doel van de wervingsinspanningen in de krijgsmacht is het aantrekken van het gewenste aantal gekwalificeerde vrijwilligers, omdat het ultieme probleem van een vrijwilligersleger natuurlijk het aantrekken van personeel is om de taken van de krijgsmacht te kunnen uitvoeren. Het aantrekken van gekwalificeerde vrijwilligers is iets anders dan het simpelweg aantrekken van potentiële vrijwilligers. De praktische implicatie van dit onderscheid is dat bij wervingsinspanningen niet alleen naar het werven zelf moet worden gekeken, maar dat tegelijkertijd moet worden gekeken naar de classificatie, selectie en aanstellingsmogelijkheden van vrijwilligers.

In brede zin is het wervingssysteem verantwoordelijk voor (1) het aantrekken van vrijwilligers die werk zoeken in de krijgsmacht, ${ }_{r}(2)$ het classificeren van vrijwilligers op hun geschiktheid voor militaire dienst, (3) de selectie van vrijwilligers, en (4) het bepalen waar de geselecteerde vrijwilliger aan het werk kan. Over het aantrekken van vrijwilligers en daarmee het bepalen van het aanbod van vrijwilligers is in paragraaf 6.1. reeds uitvoerig gesproken. Punt (4) is impliciet aan de orde gekomen in paragraaf 6.2, omdat we daar het "matching"-principe als uitgangspunt hebben genomen. De werkplek wordt zoveel mogelijk in onderling overleg vastgelegd, rekening houdend met zowel de wensen van de vrijwilliger als de wensen van de krijgsmacht. In deze paragraaf staan de elementen (2) en (3) dus centraal. 
Bij het classificeren van vrijwilligers staat de kwaliteit van de vrijwilliger voorop. Wat nu precies kwaliteit is, is moeilijk te omschrijven omdat er geen kant en klare maatstaf voor kwaliteit is. Kwalliteit is een relatieve maatstaf.

In de Nederlandse krijgsmacht wordt bij vrijwilligers een onderscheid gemaakt naar vooropleiding en fysieke en mentale geschiktheid. Bij de vooropleiding wordt een onderscheid gemaakt naar type schoolopleiding en bij de fysieke en mentale geschiktheid wordt aangesloten bij principes uit de verzekeringsgeneeskunde en psychologische testen Bil de keuring wordt niet alleen gekeken naar de medische toestand volgens de ABOHZIS-formule ${ }^{26}$, maar aok naar welk risico vrijwilligers lopen wanneer zij in militaire dienst aan zware inspanningen worden blootgesteld.

Met behulp van alle scoringsresultaten is vervolgens een classificatie te maken. Aan een classificatiesysteem zijn voor- en nadelen verbonden. Het grote voordeel van een classificatiesysteem, en daar is het ook voor bedoeld, is dat gemakkelijk een selectie kan worden gemaakt uit de vrijwilligers die zich hebben aangeboden. Vrijwilligers die een bepaalde grens overschrijden in de classificatie worden aangenomen, terwijl de rest wordt afgewezen.

De reden om een bepaalde grens bij de selectie te trekken komt voort uit drie soorten overwegingen. Vrijwilligers die onder de grens vallen worden geacht te moeilijk opleidbaar te zijn voor het militaire beroep, zullen moeilijkheden ondervinden met het op een juiste manier uitoefenen van hur beroep en kunnen problemen krijgen met de motivatie en discipline. Of dit in dle praktijk ook zo is, is door de afwijzing op voorhand moeilijk te onderzoeken. Toch is het in een vrijwilligersleger zaak de eisen niet te hoog te stellen, omdat de vulling van het leger niet bij voorbaat gegarandeerd is. In een dienstplichtigenleger is deze situatie echter anders en zullen andere selectiegrenzen kunnen gelden.

In het algemeen kan het proces van het stellen van kwaliteitstandaards gezien worden als een statistisch besluitvormingsprobleem, waarbij het doel is die vrijwilliger's af te wijzen die niet geschikt zijn voor de krijgsmacht, maar wel in het achterhoofd te houden dat de selectiegrenzen niet zo strak moeten worden vastgesteld dat geschilkte vrijwilligers toch worden geëlimineerd. Ter illustratie het volgende: verondersteld wordt dat een individuele vrijwilliger geschikt of niet geschikt is voor de krijgsmacht. Daarnaast wordt verondersteld dat de selectiecriteria zo zijn dat de individuele vrijwilliger wel of niet geaccepteerd wordt.

Figuur 6.2. Statistisch besluitvormingsprobleem bij het vaststellen van selectiecriteria.

\begin{tabular}{|l|l|l|}
\hline Acceptatie & Geaccepteerd: $\mathrm{x} \%$ & Afgewezen: $\mathrm{y} \%$ \\
\hline Hypothese & $(1)$ & $(2)$ \\
& Correct & Incorrect \\
& $\left(1-Z_{1} \%\right)$ & $Z_{2} \%$ \\
\hline Geschikt & $(4)$ & $(3)$ \\
\hline Ongeschikt & Incorrect & Correct \\
& $Z_{1} \%$ & $\left(1-Z_{2} \%\right)$ \\
\hline
\end{tabular}

\footnotetext{
${ }^{26}$ De ABOHZIS-formule is een classifficatiesystieem voor de fysieke geschilktheid van de vilijwilliger. Iedere letter stast voor een beparilde eigenschap van het menselijlk lichaam en krijgt de walarde 1 tot en met 5 . De A staat voor Aigemeen, $B$ is bowenste ledematien en longen, $O$ is onderste ledematen, $H$ is horen, $Z$ is zien, $I$ is intelligentie en $S$ is stabiliteit.
} 
Uit figuur 6.2. kumnen we opmaken dat er vier mogelijke combinaties zijn onder dit eenvoudige besiuitvormingsprobleem: (1) de vrijwilliger is geschikt en wordt geaccepteerd door de selectiecriteria, (2) de vrijwilliger is geschikt, maar wordt door de selectiecriteria afgewezen, (3) de vrijwilliger is niet geschikt en wordt afgewezen en (4) de vrijwilliger is ongeschikt, maar wordt door de selectiecriteria geaccepteerd. Het tweede geval, het afwijzen van een vrijwilliger die geschikt is, wordt in de statistiek een fout van de eerste soort genoemd. Het vierde geval, het accepteren van een vrijwilliger die niet geschikt is, wordt een fout van de tweede soort genoemd. Omdat geen enkel criterium perfect kan voorspellen, veronderstellen we dat een fout van de eerste soort $Z_{1} \%$ van de keren dat een vrijwilliger geschikt is voorkomt en dat een fout van de tweede soort $Z_{2} \%$ van de keren voorkomt, wanneer een vrijwilliger niet geschikt is. De relatie tussen $Z_{1}$ en $Z_{2}$ is dat als $Z_{2}$ afneemt, $Z_{1}$ in het algemeen toeneemt, ceteris paribus. 27

Om de juiste selectiestrategie op te stellen, moeten we het selectieproces in een kostenplaatje zetten. Er zijn kosten verbonden aan het maken van foute beslissingen, en er zijn diverse administratiekosten verbonden aan het selectieproces. De kosten die te maken hebben met een fout van de eerste soort, het afwijzen van een geschikte vrijwilliger, zijn de "opportunity costs" van het afwijzen van een produktief persoon in de krijgsmacht. De kosten van een fout van de tweede soort bevatten de kosten die gemaakt zijn voor het werven, selecteren en trainen van een ongeschikt persoon, omdat deze persoon nooit zijn initiële kosten zal waarmaken. De totale kosten verbonden aan ieder selectieproces zijn daarom een functie van (1) de kosten van het maken van een incorrecte beslissing ten aanzien van de geschiktheid van een vrijwilliger, (2) de waarschijnlijkheid van het maken van een verkeerde beslissing, en (3) de administratiekosten van het selectieproces. Indien we veronderstellen dat de kosten van een fout van de eerste soort $C_{1}$ zijn, de kosten van een fout van de tweede soort $C_{2}$, de administratiekosten $A$, en dat $b \%$ van alle vrijwilligers geschikt is (dus $(1-b \%)$ is niet geschikt), dan kunnen de totale kosten van het selectieproces als volgt berekend worden:

Kosten $=\left[b \% Z_{1} C_{1}\right]+\left[(1-b \%) Z_{2} C_{2}\right]+A$.

Deze kostenfunctie helpt ons ondermeer verklaren, waarom de selectiegrenzen in een dienstplichtigenleger zo hoog zijn gesteld dat slechts $73 \%$ wordt goedgekeurd. De "opportunity costs" van een fout van de eerste soort zijn in een dienstplichtigenleger vrijwel verwaarloosbaar, omdat voor ieder individu dat ongeschikt wordt verklaard een alternatief individu klaar staat om zijn plaats in te nemen. In een vrijwilligersleger moet dit alternatieve individu eerst geworven worden, terwijl de krijgsmacht tijdelijk een produktieverlies lijdt, omdat zij haar functies niet op sterkte heeft. De toegevoegde waarde van de vrijwilliger ontbreekt. lets dat in een dienstplichtigenleger niet voorkomt, omdat de open plaatsen daar onmiddelijk worden opgevuld.

In een dienstplichtigenleger zijn de kosten die samenhangen met een fout van de tweede soort verre van verwaarloosbaar. Training, uitrusting enz. kosten veel geld.

27 Dat will zeggen, des te stringenter de selectiecriteria (munder "fouteri" zijn toeggestaan in de krijgsmacht), des to groter zal het aantal geschikte wrijwilligers zijn dat wordt afgewezen. Indien de ceteris paribus conditie wordt losgelaten, bijvoorbeeld indien er betere voorspellers ontwikkeld worden, kunnen de ciffers woor $z l l$ en $z 2$ beicien

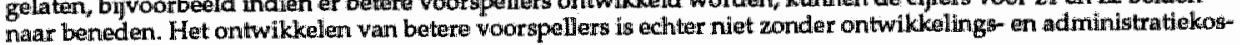
ten. 
De dienstplicht moedigt de krifgsmacht aan selectiegrenzen te ontwikkelen die gemakkelijk te administreren zijn (om de kosten te minimaliseren) en die de gevolgen van een kostbare fout van de tweede soort minimaliseren. De overgang van een dienstplichtigenleger naar een vrijwilligersleger maakt een fout van de eerste soort nu erg kostbaar, omdat iedere geschikte vrijwilliger die geweigerd wordt een reductie betekent van een toch al schaars aanbod.

In het algemeen betekent dit dat het afschaffen van de dienstplicht gepaard zal moeten gaan met het verlagen van de toelatingseisen tot de krijgsmacht en niet het verscherpen van deze toelatingseisen. Bij de dienstplicht had de krijgsmacht een oneindig aanbod en had zij alle recht hoge eisen te stellen. In een vrijwilligersleger mag zij pas eisen stellen indien het aanbod van vrijwilligers de behoefte van de krijgsmacht overtreft.

Bij het naar beneden bijstellen van de selectiegrenzen is het belangrijk voor ogen te houden dat dit niet de bedoeling heeft de kwaliteit van de vrijwilligers te reduceren, maar te erkennen dat "standaard kwaliteit" maatstaven geen perfecte voorspellers zijn. Het verlagen van de selectiegrenzen zal moeten doorgaan tot het punt waarop de marginale kosten van een fout van de eerste soort gelijk zijn aan de marginale kosten van een fout van de tweede soort: $d C_{1}=d C_{2}$, waarbij $C_{1}$ gelijk is aan het produktieverlies, de kosten van de extra wervingen en de extra selectiekosten. $C_{2}$ is gelijk aan de uitrustingskosten, trainingskosten en de extra kosten welke verbonden zijn aan sellectieverbetering.

In de Verenigde Staten hebben Chu en Norrblom ${ }^{28}$ in 1974 onderzoek gedaan naar de relatie tussen kosten van fouten van de eerste soort, kosten van fouten van de tweede soort en het verlagen van selectiegrenzen. Zij schatten dat de kosten die te maken hebben met fouten varu de tweede soort, zoals de verloren trainingskosten, in de buurt komen van $\$ 5$ tot $\$ 7$ miljoen per jaar, wanneer de selectiegrenzen zo verlaagd worden dat het aantal gekwalificeerde vrijwilligers met $5 \%$ zal stijgen. Daarentegen zal bij ongewijzigde selectiegrenzen een toename van $5 \%$ van het aantal vrijwilligers om extra salarissen vragen ter grootte van ongeveer $\$ 300$ miljoen per jaar. Met andere woorden, Chu en Norrblom komen tot de conclusie dat bij het verlagen van de selectiegrenzen, om $5 \%$ meer gekwalificeerde vrijwilligers te krijgen, de term $\left[(1-b \%) Z_{2} C_{2}\right]$ in vergelijking 6.3. stijgt met $\$ 5$ tot $\$ 7$ miljoen per jaar $r_{r}$ maar de term $\left[6 \% Z_{1} C_{1}\right]$ afneemt met $\$ 300$ miljoen per jaar.

Zowel uit vullingsoogpunt als uit kostenoogpunt is het dus te verwachten dat bij een overgang van een dienstplichtigenleger naar een vrijwilligersleger de selectiegrenzen worden verlaagd. Toch is dit niet de praktijk. Daar waar van de dienstplichtigen ongeveer $70 \%$ per jaar wordt goedgekeurd, wordt van de echte vrijwilligers zeven op de acht afgewezen en dan met name op mentale gronden 29

In de volgende subparagrafen zal worden beschreven dat het helemaal niet noodzakelijk is om hoge selectie-eisen te stellen ten einde de kwaliteit van het personeel te waarborgen. In paragraaf 6.3.1. zullen daartoe twee projecten in de Verenigde Staten worden besproken. Het eerste project. Project 100.000 , maakte deel uit van de "War on Poverty" van President Johnson en had tot doel om te zien of vrijwilligers, die eerst waren afgewezen op mentale gronden, toch bevredigend konden functioneren in de krijgsmacht, indien de krijgsmacht ze gewoon een kans

\footnotetext{
28 David S.C. Chu en Eva Norrblom, Physical Standarde in an AlH-Volunteer Force, "The Rand Corporation, April
1974 .

${ }^{29}$ Rapport Commissie dienstplicht, onderdeel arbeidsmarktonderzoek, blz.24. Het getal reven op de acht geldt voomamellijk voor de Koninklijke Landmacht. De andere krì̈gs machtdelen kennen hogene innamecijfers.
} 
gaf. Het tweede project was een onbewust project, maar bleek zeer interessant toen naar voren kwam dat in de jaren 1976-1980 de classificatiesystemen niet goed gefunctioneerd hadden en zo'n 300.000 vrijwilligers met geinfleerde test-scores toch geaccepteerd waren door de krijgsmacht.

In paragraaf 6.3.2. zal een groep vrijwilligers onder de loep worden genomen, waarvoor de krijgsmacht aparte selectiecriteria opstelt, namelijk de vrouw in de krijgsmacht.

\section{\$ 6.3.1. Het "Project 100.000" en de "ASVAB-misnorming"30}

In de Verenigde Staten was de krijgsmacht het eerste instituut in de samenleving dat begon met testprogramma's op grote schaal. De eerste testen werden door psychologen ontwikkeld in de Eerste Wereldoorlog, hoewel van deze mentalle testen pas veel later echt gebruik werd gemaakt. In 1941 werd de "Army General Classification Test" (AGCT) ingevoerd. Deze test was bedoeld "as a test of general ability and was intended to be used in basically the same manner as the Army Alpha" 31

Met behulp van de AGCT en een aantal subtesten werd van ieder persoon een totaall score gemaakt en kreeg iedereen een classificatie. Snelle leerlingen kregen categorie $\mathrm{I}_{r}$ de iets minder snelle categorie II, gemiddelde leerlingen categorie $\mathrm{MI}$, beneden gemiddeld categorie IV en de langzame leerlingen categorie $\mathrm{V}$.

Na de Tweede Wereldoorlog werden de militaire standaards opgetrokken en kwamen de mensen in categorie $V$ niet meer in aanmerking voor militaire dienst. Deze uitsluiting werd wettelijk vastgelegd. Het betrof ongeveer 10 procent van alle personen.

In het midden van de jaren zestig, de AGCT was inmiddels vervangen door de "Army Forces Qualification Test" (AFQT), werd ook een onderscheid gemaakt tussen personen die wel een high-school diploma hadden en personen die niet in het bezit waren van zo"n diploma. Bezitters van een high-school diploma die hoger scoorden dan het 31e percentiel in de AFQT waren zonder uitzondering gekwalificeerd. Zat een individu tussen het 21 e en 30 e percentiel, de categorie IV, dan was hij gekwalificeerd indien hij een high-school diploma had en boven-gemiddeld scoorde bij bepaalde testen. Individuen zonder high-school diploma werden alleen aangenomen indien ze boven het 31e percentiel uitkwamen, dat wil zeggen categorie I, II en III. De stricte indeling in categorieën heeft in de Verenigde Staten meer dan eens stof tot discussie gegeven en dat niet alleen omdat de grenzen wettelijk werden vastgelegd. Zo kwam het voor dat commandanten hun mening over bepaald personeel baseerden op de kennis van de mentale categorie waar iemand in thuis hoorde.

Ook het Project 100.000 is niet aan enig commentaar ontsnapt. Het Project 100.000 was volgens de initiators bedoeld om het leven van jongeren met een achterstand in de maatschappij te verbeteren. $\mathrm{Zij}$ geloofden dat de krijgsmacht hiertoe heel goed geschikt was door de aanwezigheid van een duidelijke structuur en het vermogen en de ervaring van diezelfde krijgsmacht in het omgaan met een cultureel en economisch. diverse bevolking.

\footnotetext{
30Deze paragraaf is gebaseerd op het werk van Thomas G. Sticht, Military Testing and Public Policy: selected Studies of Lower Aptitude Personnel, in: Bernard R. Gifford en Linda C. Wing, Test Policy in Defense, Boston 1992.

31 Sticht, op cit, blz. 15. De Army alphaq" was de oude test.
} 
Project 100.000 maakte in het middert van de jaren zestig deel uit van de "War on Poverty". Voor de toenmalige minister van Defensie van de Vererigde Staten, Robert McNarnara, was het Project 100.000 een efficiente en geschikte manier om de krijgsmacht te laten dienen voor twee nationale doelen: sociale welvaart en nationale veiligheid. Het doel van het Project 100.000 was om ieder jaar 100.000 vrijwilligers in dienst te nemen, die bij een normale selectieprocedure buiten de boot zouden zijn gevallen. Daarbij zou het gaan om ongeveer $22,3 \%$ van de viijwilligers in categorie IV, de laagste geschilkte categorie. De kosten van het project werden geacht zich terug te verdienen in de maatschappij door een hogere scholingsgraad, vakbekwaamheid en een vergroot zelfvertrowwen bij de honderdduizenden jongeren, die door het Project 100.000 nu wel in aanmerking kwamen voor de millitaire dienst.

MoNamara zag het Project 100.000 als een "gecontroleerd experiment" van het effect van de krijgsmacht op de jongeren met een achterstand en vice versa. Sommige leden van het militaire apparaat en parlementariërs zagen dit anders en zeiden dat het in dienst nemen van minder geschikte vrijwilligers de krijgsmacht zou verzwakken, zoals blijkt uit de woorden van Evans:

"The results were neither satisfactory nor equitable. The "New Standards" men flunked out of basic training th twice the usual rate, were court-martialed and dismissed with premature discharges twice as often. Among cynics in the Pentagon, the program was soon dubbed McNamara's Moron Corps ${ }^{\text {t". }}$.32

Anderen hadden weer andere bezwaren, zoals blijkt uit het verhaal van Baskir en Strauss:

"In the opinion of many military leaders, social planners and liberal critics, Project 100.000 proved a failure. While it expanded the wartime manpower pool, it also required additional resources which the services could ill afford. But above all, it was a failure for the recruits themselves. They never got the training that millitary service seemed to promise. They were the last to be promoted and the first to be sent to Vietnam. They saw more than their share of combat and got more than their share of bad discharges. Many ended up with greater difficulties in civilian saciety than when they started. For them, it was an ironic and tragic conclusion to a program that promised special treatment and a brighter future, and denied both." 33

De conclusies van Evans, Baskir en Strauss staan in schril contrast met de conclusie van de "Presidents Commission on an all-volunteer force", die verklaarde dat:

"one cannot help but conclude that the Project 100.000 experiment has been a success and should be continued" ${ }^{\text {th }} 34$

Om achter de echte waarheid te komen heeft Sticht een zeer grote hoeveelheid data verzamell dat twee groepen omvatte: een groep met mensen uit het Project 100.000 en een vergelijkbare "controle groep" met niet-Project 100.000 mensen. Sticht heeft beide groepen in kaart gebracht en de statistieken over de twee groepen uitgewerkt om te zien of de doelen van het Project 100,000 werden bereikt, er vooruitgang werd geboekt door de vrijwilligers op diverse terreinen en om te zien of de vrijwilligers van het Project 100.000 inderdlad minder van kwaliteit waren, zoals de critici beweerden.

\footnotetext{
32 Evans, The Army and the Underclass: losing Battle, in Sticht, blz. 21.

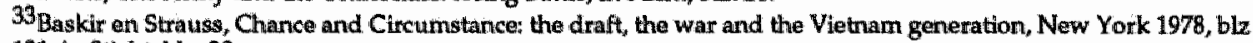
131, in Sticht, ble. 20.

34 Sticht, op cit.; bliz. 21 .
} 
Het basistrainingsprogramma werd door $94 \%$ van de Project 100.000 vrijwilligers afgemaakt. Bij de "controle groep" van meer geschikte vrijwilligers was dit percentage $98 \%$. Ook bij het aanleren van de vakbekwamheid lagen de vrijwilligers uit het Project 100.000 weinig achter. Meer dan 90\% hoefde geen opleidingsonderdeel over te doen en meer dan $85 \%$ voldeed aan de vereisten van geconcentreerd leren en testen en maakte de training in én keer af. In de gehele krijgsmacht maakte $86 \%$ van de vrijwilligers van Project 100.000 zijn totale diensttijd vol. Voor de "controle groep" was dit $92 \%$

Van de vrijwilligers die afvielen, viel minder dan de helft af vanwege slecht gedrag of ongeschiktheid. De meerderheid viel af door reeds bestaande medische problemen, kwam om het leven in de Vietnam oorlog, en andere redenen.

In de Landmacht werd $95 \%$ van de vrijwilligers van het Project 100.000 als "highly efficiënt" gezien, zodat gezegd kan worden dat ook hier geen problemen waren. Een belangrijke factor van kritiek bij het Project 100.000 was dat de instroom van jongeren met een achterstand in de maatschappij disciplinaire problemen zou veroorzaken:

"Project 100.000 men were courtmartialed and dismissed with premature discharges twice as often as non-Project 100.000 men". ${ }^{35}$

Letterlijk was dit waar, maar wat de critici vergaten te vermelden was dat het totale percentage $3,2 \%$ was, vergeleken met $1,6 \%$ voor dle "controle groep". Meer dan 95\% heeft nooit iets te maken gehad met de krijgsraad. Ook tuchtrechtovertredingen ontliepen elkaar voor beide groepen niet veel, wardoor we kunnen zeggen dat de veronderstelde disciplinaire problemen niet gestaafd werden door de cijfers.

Concluderend kunnen we stellen dat het Project 100.000 heeft laten zien dat vrijwilligers uit de mentale categorie IV relatief goed functioneerden, zowel bij de training als op het werk. De resultaten laten zien dat de verschillen tussen de beide groepen vrij klein zijn, in ieder geval op ieder terrein minder dan 5 tot 10 procentpunten. Verlaging van de selectiegrenzen mag dan in termen van fouten van de tweede soort leiden tot een toename van de kosten, deze kosten worden in maatschappelijk oogpunt dubbel en dwars terugverdiend.

In het Project 100.000 werden de selectiegrenzen door een politieke beslissing naar beneden bijgesteld. Bij de "ASVAB-misnorming" leidde een technische fout tot een onbedoelde en niet herkende verlaging van de selectiegrenzen. De technische fout bestond daaruit dat bepaalde tabellen die gebruikt werden om Armed Services Vocational Aptitude Battery (ASVAB) scores om te zetten in percentiel scores niet goed ingeschaald waren.

De ASVAB was in 1976 ingevoerd en het duurde tot 1980 voordat werd ontdekt dat er technische fouten waren gemaakt. In 1979 dacht het Ministerie van Defensie in de Verenigde Staten dat $5 \%$ van de krijgsmacht bestond uit vrijwilligers uit de categorie $I V$, doch in werkelijkheid bleek dat $30 \%$ te zijn. Toen ontdekt was dat honderdduizenden minder geschikten toch een plaatsje in de krijgsmacht hadden gevonden, werden er studies opgezet om te ontdekken hoe de prestaties van deze vrijwilligers verschilden van vrijwilligers die onder alle omstandigheden geschilkt zouden zijn verklaard. De technische fout in de ASVAB leidde dus tot een "neutraal experiment". In dit experiment zijn militaire leiders onbewust geweest van het feit dat zij honderdduizenden categorie IV vrijwilligers in dienst hadden genomen die eigenlijk "potentially ineligible (PI)" waren.

$35_{\text {idem. }}$ 
Omdat de krijgsmacht zich niet bewust was van de fout, is er weinig commentaar te horen over de kwaliteit van de troepen in deze periode, dit in tegenstelling tot wat het geval was in de Tweede Wereldoorlog en bij het Project 100,000. In interviews met bataljonscommandanten was er bijna niemand die klaagde over de geschiktheid van de troepen. In een opgenomen gesprek in 1979 in West-Duitsland vroeg Sticht $t^{36}$ aan een commandant of de nieuwe soldaten goed konden omgaan met het ingewikkelde wapenmaterieel. De commandant antwoordde:

"You can talk to any of my commanders and any of my non-commissioned officers. I believe that 99 percent of them will tell you-l kriow they will-because they tell me the same thing; just what I'm going to tell you. That is baloney. We considet our soldiers to be outstanding. Our non-commissioned officers are outstanding. We've got outstanding officers. They're the best that I've ever seen. IWhen asked, What about the new guys?] I m talking about the new guys, privates coming in. I have sergeants tell me every day, 'Boy these new privates that are coming in are great. We're really getting some good soldiers in:" Why do they say that; Because that"s the way we think about our soldiers. We choose to believe that our soldiers are darnn good, from the day they walk in and to the extent that they aren't, that's our responsibility. We have the capability and space to see to it that they are helped".

Uit de studies die na het ontdekken van de fout in de ASVAB volgden, bleek dat de woorden van de commandant in vrijwel de gehele krijgsmacht opgeld hadden gedaan. De PIs deden het slechts een klein beetje minder dan de geschikte vrijwilligers. De verschillen waren net als in het Project 100.000 niet erg groot, terwijl op sommige terreinen de PIs zelfs beter scoorden. In de landmacht waren de verschillen tussen PIs en personeel uit de hoogste geschiktheidscategorieën I en II niet zo groot, bij de marine en de luchtmacht waren de verschillen wel duidelijk aanwezig. Deze verschillen worden verklaard door de grotere aandacht voor studie en schriftelijke testen bij de marine en de luchtmacht. Toch bleven de uitvalpercentages gedurende velen jaren constant. Uit de "ASVAB-misnorming" studies is dan ook op te maken dat de geschiktheid van vrijwilligers veel meer te maken heeft met hoe mensen op het werk presteren en begeleid worden, dan met pen-en-papier testen. Vrijwilligers uit categorie IV presteren minder indien de prestatie gemeten wordt aan de hand van schriftelijke testen, doch de werkelijke met de hand uitgevoerde prestatie ligt veel hoger, wat ondermeer blijkt uit de waardering van hun werk door hun meerderen. In 1987 werd dit nogmaals bevestigd door het Ministerie van Defensie: ${ }^{37}$

"Upon looking at their performance, we learned that a surprisingly large number of them became suc-
cessful members of the milltary. If the enlistment standards were working properly, those young
people should have been marginal performers at best. As it turned out, not only did they not have
marginal performance, many of them performed considerable above that level. They completed tral-
ning; their attrition tates weren"t unusually high, they were promoted at rates only slightly lower than
their higher scoring peers; and they reenlisted. So, the question was not that training grades were so-
mehow flawed, but that a quarter-of-a-million people who did not meet the enlistment standards and
should not have been able to do the job did in fact do pretty well".

Toch hebben deze resultaten niet geleid tot het blijvend in dienst houden van vele categorie IV vrijwilligers. De ontdekking van de foute inschaling van de ASVAB leidde er toe dat het aantal vrijwilligers uit categorie IV van 30 procent in 1980 afnam tot 4 procent in 1986, hoewel daar eigenlijk in zijn geheel geen aanleiding toe was.

36 sticht, op cit. blz. 62 .

37 Sticht, op cit blz 64. 
De onderzoeken naar zowel het Project 100.000 als de "ASVAB-misnorming" laten zien dat de actuele kwalificatiestandaards in de Verenigde Staten vrijwilligers uitsiuiten die op zijn minst acht op de tien keer succesrijk zijn. Ondanks het feit dat de classificatiesystemen objectieve maatstaven aanleveren blifft het stellen van selectiegrenzen een subjectieve, psychologische en arbitraire zaak. De commandanten willen de beste soldaten, omdat de prestaties van zijn onderdanen de basis vormen van zijn beoordeling. Des te lager de vermeende geschiktheid van zijn soldaten, des te minder rooskleurig ziet de commandant zijn toekomst in, terwijl daar in zijn geheel geen reden toe is. De klachten van commandanten over de geschiktheid van zijn personeel zijn veelal een psychologische zaak, veroorzaakt door het in classificatiegroepen onderbrengen van zijn personeel. Is de commandant niet op de hoogte van de geschiktheid van zijn personeel of wordt hem onjuiste informatie gegeven over deze geschiktheid dan smelt het commentaar als sneeuw voor de zon. Dit was ook al zo in de Tweede Wereldoorlog. Een rapport van het Ministerie van de Landmacht van de Verenigde Staten in de Tweede Wereldoorlog laat zien dat. ${ }^{38}$

"During World War II, commanders complained that they were getting too many men in the lowest mental category. The Department of the Army then arbitrarily decreed that the top half of that category would henceforth be classified in the next higher category. Commanders practically ceased their complaints, although they were getting the same number of low quality men as before-but now only half as many were designated as being in the lowest mental category".

De les die uit deze paragraaf getrokken kan worden is dat het gebruik van classificatiesystemen en het stellen van selectiegrenzen een groot maatschappelijk belang heeft. Niet alleen kost het stellen van hoge selectiegrenzen veel geld in termen van extra salaris en wervingskosten, veel belangrijker is het de sociale gevolgen van deze eisen onder ogen te zien. Het weigeren van "potentieel minder geschikte" vrijwilligers heeft niet alleen gevolgen voor de vrijwilliger zelf, maar ook voor het gezin en de omgeving waar deze vrijwilliger uit voort komt. Voor de vrijwilligers is er het gemis aan arbeidservaring, scholing en zelfvertrouwen. Voor de gexinnen is het extra inkomen vaak ook van harte welkom, maar nog meer maken gezinnen gebruik van intergenerationele opbrengsten door de ervaringen van de vrijwilliger. Ook zal zijn omgeving er eventueel voordeel mee hebben, indien de vrijwilliger als voorbeeld voor de rest gaat dienen.

In Nederland worden van iedere acht vrijwilligers er zeven afgewezen. Dit kan nooit in het belang van de samenleving zijn. Het maatschappelijk belang moet bij ledere publieke beslissing voorop staan en niet alleen het belang van de krijgsmacht of de individuele commandant.

In een vrijwilligersleger is de opkomstplicht van de dienstplicht buiten werking gesteld, de dienstplichtwet blifft echter voortbestaan. Alleen in een uiterste noodsituatie zal gebruik worden gemaakt van de opkomstplicht en zal ook gebruik worden gemakkt van de diensten van "potentieel minder geschikte" vrijwilligers. Dit creëert een situatie warin deze jongeren wel het smerige werk mogen opknappen in een noodtoestand, maar dat tijdens vredestijd, waarin de levensrisico's vrij klein zijn, deze vrijwilligers uitgesloten zijn van alle yoordelen van militaire dienst en misschien wel de droom van hun leven.

Dit alles pleit voor zo laag mogelijke selectiegrenzen en een verandering van de maatstaven die de krijgsmacht in Nederland gebruikt. Het stellen van lage selec-

\footnotetext{
$38_{\text {Sticht }}$ op cit. blz 44 .
} 
tiegrenzen heeft vrijwel geen effect op de kwaliteit van de krijgsmacht, bespaart de belastingbetaler een hoop geld, geeft jongeren een echte kans en brengt een sociaal bewustzijn in de krijgsmacht.

\subsubsection{De vrouw in de krijgsmacht}

De dienstiplicht bestaat uitsluiterd voor mannen. Onder de beroepsmilitairen zijn slechts een beperkt aantal vrouwen aanwezig. Als de dienstplicht verdwijnt, wordt arbeid schaars, en wordt de vrouw in de krijgsmacht des te interessanter. Dat er slechts weinig vrouwen in de krijgsmacht aanwezig zijn, heeft ondermeer te maken met de fysieke eisen, die aan de lichamelijk zware functies in de krijgsmacht worden gesteld. Omdat vrouwen gemiddeld minder sterk zijn dan mannen, wordt vaak het argument aangevoerd dat een groot aantal vrouwen de effectiviteit van de krijgsmacht aantast.

In deze paragraaf zal nader naar de positie van de vrouw in de krijgsmacht worden gekeken, waarbij de paragraaf zich langs twee lijnen uitstrekt. De eerste lijn betreft de effectivitelt van de vrouw in de krijgsmacht, de tweede handelt over de efficiëntie van de vrouw ten opzichte van de man als werknemer in de krijgsmacht. Bij deze laatste analyse wordt uitgegaan van het feit dat de vrouw effectief is en wordt gekeken naar de extra kosten of kostenbesparingen die de aanwezigheild van de vrouw in de krijgsmacht met zich mee brengt.

"Sinds 1 januari 1982 bestaan er in de Wederlandse krijgsmacht geen beroeps- of kortwerbandfuncties meer specifiek voor mannen of vrouwen. Met deze erkenning van het recht van de vrouw op het vervullen van jedere functie in de krijgsmacht zijn uiteraard niet de problemen opgelost die de toetreding van de vrouw tot de krijgsmacht op gelijke voet als de man brengt".

Op deze wijze stelt de Maatschappelijke Raad voor de Krijgsmacht (MRK) het probleem van de vrouw in de krijgsmacht aan de kaak. Het advies van de $\mathrm{MRK}^{39}$ komt voort uit een verzoek van de bewindslieden op het Ministerie van Defensie over de wijze waarop vrouwen binnen de krijgsmacht kunnen functioneren.

Uit de adviesaanvraag blijkt dat zij voomamelijk de effectiviteit van de vrouw in de krijgsmacht voor ogen hadden, omdat, zoals we reeds eerder zagen, slechts weinig vrouwen kunnen voldoen aan de lichamelijke eisen die aan fysiek zware functies worden gesteld. Tot die fysiek $z$ ware functies rekent de aanvrager van het advies, statissecretaris Hoekzema, een groot deel van de gevechtsfuncties.

Uit de omschrijving van de adviesaanvraag blijkt bovendien dat het advies een absoluut kwalitatief probleem zou moeten beschurijven. Dit is echter niet juist. De gemiddelde vrouw is inderdaad fysiek zwakker dan de gemiddelde man, maar in de praktijk gelden geen statistische gemiddelden, maar hebben we te maken met individuele mensen die in allerlei opzichten var elkaar verschillen. Er zijn namelijk ook sterke vrouwen en zwakke mannen. Willen we daadwerkelijk de effectiviteit van de vrouw in de krijgsmacht onder de loep nemen, dan dienen we het niet specifiek over de effectiviteit van de vrouw te hebben, maar over de effectiviteit van alle fysiek zwakkere mensen. Een absoluut kwalitatief probleem wordt dan een relatief kwalitatief probleem. Het is niet het onderscheid tussen mannen en vrouwen dat hier speelt, maar tussen fysiek sterke en minder sterke mensen. Waar de selectiegrenzen dan ge-

39 Maatschappelijke Raad voor de Krijgsmacht, advies nr 7: "De vroww in de krijgsmacht", Den Haag 1984. 
trokken moeten worden is vervolgens een politieke vraag. Niet een politieke vraag tussen man of vrouw, maar dezelfde politieke vraag die we in de vorige paragraaf 6.3.1. hebben gezien: "Waar trekken we grenzen in het classificatiesysteem?" Uit het rapport van de MRK is bovendien op te maken, dat:

"In de burgermaatschappij er voor weinig soorten werk nog bijzondere lichaamskracht vereist is. Door het bestaan van vele technische hulpmiddelen is een onderscheid tussen mannen-en vrouwenberoepen alleen nog maar te verklaren uit historische en culturele gronden. Overigens is een van de zwaarsite beroepen het beroep van huisvrouw, een beroep waarbij onder meer zwaar sjouwwerk aan de orde van de dag is. Het is bovendien een gevaarlijk en verantwoordelijk beroep gelet op het grote aantal ongevallen dat zich binnen particuliere woningen voordoet". 40

Hieruit vollgt nogmaals dat de aanwezigheid van vrouwen in bepaalde beroepen niet zozeer bepaald wordt door de fysieke zwaarte van het beroep, maar meer cultureel bepaald is. Of omgekeerd geredeneerd: doordat in de meeste beroepen vrijwel alleen mannen werken, is door de gemiddelde grotere kracht van het mannelijke geslacht soms ten onrechte verzuimd fysiek zware klussen te verlichten, waardoor de toetreding van vrouwen weer extra bemoeilijkt wordt.

Dit geldt nog in sterkere mate voor de krijgsmacht. De krijgsmacht kent een groot aantal functies. Functies die we niet alleen kunnen onderverdelen in gevechtsfuncties en niet-gevechtsfuncties, maar ook in fysiek zware en fysiek minder zware functies. Daarnaast kent de krijgsmacht ook de dienstplicht. Door de dienstplicht wordt werk door mannelijke werknemers verricht dat onder normale omstandigheden door machines zou worden gedaan.

De allocatie-effecten door de dienstplicht hebben niet alleen effect op het werk dat de dienstplichtigen doen, maar ook op de beroepsmilitairen en de burgers in de krijgsmacht. De prikkel om de arbeidsomstandigheden te verbeteren en de schadielijke fysieke belasting voor de fysiek minder sterken te verminderen is door de dienstplicht niet aanwezig. Daarom zijn ergonomische maatregelen om het werk aan te passen aan de fysieke mogelijkheden van de individuele mens vaak achterwege gebleven en is het voor een vrouw wel heel erg moeilijk om zich in fysiek opzicht staande te houden.

In hoofdstuk 5 hebben we kunnen zien, dat in een vrijwilligersleger de werkelijke kosten van de produktiefactor arbeid in de krijgsmacht aan het licht komen. Vrijwilligers zijn schaars en duur, waardoor de noodzaak ontstaat militairen te vervangen door burgers, millitairen te vervangen door kapitaalgoederen en onervaren militairen in te wisselen voor meer ervaren militairen. Door de militair-burger substitutie komt het onderscheid tussen gevechtsfuncties en niet-gevechtsfuncties aan het licht. In hoofdstuk 5 is naar voren gekomen dat de verhouding gevechtsfuncties/nietgevechtsfuncties in een vrijwilligersleger ongeveer $1: 1$ is. Dit betekent dat $50 \%$ van de functies zonder meer geschikt is voor vrouwen.

Indien we de gevechtsfuncties onder de loep nemen, dan blijkt dat na de militairkapitaal-substitutie nog maar weinig functies een duidelijke fysieke inspanning vragen. Door de hoogwaardige technologie op de schepen bij de marine, de vliegtuigen bij de luchtmacht ${ }^{41}$ en de voertuigen bij de landmacht is vaak niet meer nodig dan een

\footnotetext{
40 Zie MRK-advies nr. 7 , blz. 18 en19.

41 Een witzondering betreft hier de $\mathrm{F}-16$. Uit het functioneren van vrouwelijke pilotien blijkt dat zelfs het best getrainde vrouwelijke lichaam niet goed bestand is tegen de krachten die door het vliegen in Fen F-16 gevechtsviliegtuig worden opgeroepen. Het is natuurlijk bijna overbodig mede te delen dat vele mannen ook afvallen.
} 
druk op een knop of de bediening van een stuurknuppel. De benodigde fysieke inspanning is door de wapenwedloop waak al flink gereduceerd.

Slechts de pure fysieke gevechtsfuncties bij de pantserinfanterie zijn functies waar de gemiddelde vrouw minder zal kunnen presteren dan de gemiddelde man. In de overige functies kan door middel van ergonomische investeringen de prestatie van de vrouw gelijk worden getrokken aan de prestatie van de man. Overigens betekent dit niet dat vrouwen uitgesloten dienen te worden van functies bij de pantserinfanterie. De omstandigheid dat de gemiddelde man meer kan presteren dan de gemiddelde vrouw betekent voor de verhouding mannen-vrouwen in fysiek zware functies als de pantserinfanterie altijd een grotere hoeveelheid geschikte mannen dan vrouwen.

Feitelijke openstelling van fysieke zware functies voor vrouwen kan een extra stimulans zijn om mede ten behoeve van mannen te zoeken naar methoden die de zware lichamelijke arbeid kunnen verlichten. Dit zoekproces is door de aanwezigheid van dienstplicht, en dus de afwezigheid van schaarsteprikkels, nooit echt van de grond gekomen.

Het achterwege laten van de noodzakelijke ergonomische investeringen is te vergelijken met een fout van de eerste soort, zoals we die in paragraaf 6.3. gezien hebben. De krijgsmacht dient een keuze te maken tussen de kosten van ergonomische investeringen en de kosten van het bieden van hogere salarissen. Uit een nadere analyse zal moeten blijken waar de marginale kosten van beide beslissingen gelijk zijn aan elkaar. Het verhogen van de salarissen is zeer kostbaar, omdat een verhoging van het salaris van de laagst betaalden in de krijgsmacht doorwerkt in het gehele loongebouw van de organisatie, terwijl ergonomische investeringen deze bijwerking niet kennen. De kostenverhouding tussen fouten van de eerste soort en fouten van de tweede soort, zoals door Chu en Norrblom in paragraaf 6.3. naar voren is gebracht, mag hier zeker als voorbeeld dienen, zodat het vrijwel geen twijfel lijdt dat ergonomische investeringen goedkoper zijn dan het verhogen van salarissen om nieuwe vrijwilligers aan te trekken.

Ondanks alle arbeidsbesparende en ergonomische investeringen zal er in de praktijk een onderscheid tussen fysiek zware en fysiek minder zware functies over blijven. Bij het opstellen van de functie-eisen voor de verschillende functies maakt de Koninklijke Landmacht een onderscheid tussen functiegroepen 1, 2 en 3. Uit dit onderscheid volgt automatisch een grotere nuancering en differentiëring in functie-eisen. Toch werkt het onderscheid in de praktijk niet, omdat de differentiëring niet per functie geschiedt, maar per wapen of dienstvak. In deze dienstvakken worden alle functies dan weer over één kam geschoren. Voor het relatief lichte werk als radarbedienaar bij de artillerie wordt functiegroep 2 (gemiddeld zwaar werk) gevraagd, terwijl voor het zware werk van gewondendrager bij de geneeskundige troepen functiegroep 3 (licht werk) geldt.42 De wat ruwe functiegroepindeling in de Koninklijke Landmacht komt er op neer dat vrouwen voor bepaalde wapens in feite geheel zijn uitgesloten.

Uit dit voorbeeld blijkt dat deze uitsluiting eerder uit culturele gronden voort-

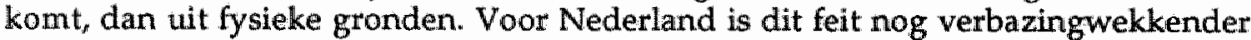
omdat vroeger, toen er nog vrouwenkorpsen bestonden, vrouwen tot ieders tevredenheid in functies hebben gewerkt, waarvoor ze nu niet meer in aanmerking komen. Een ander nadeel van het vastleggen van fysieke eisen per wapen of dienstvak blijkt bij de opleiding van vrouwelijke militairen. De meeste vrouwen die wel door de keuring en selectie zijn gekomen, vallen in vergelijking met de mannen veel vaker af

42Zie MRK-advies, nr. 7, blz. 52. 
doordat zij niet aan de fysieke eisen van de opleiding kunnen voldoen. In een vrijwilligersleger kan dit niet langer worden volgehouden. De functie-eisen dienen per functie te worden vastgesteld en niet per wapen of dienstvak.

De geschiktheid voor de militaire dienst zal bij de keuring en selectie moeten worden vastgesteld, en zo weinig mogelijk tijdens de opleiding. De selectie en de opleiding is gericht op de functie binnen het wapen of dienstvak en in principe niet op het gehele wapen of dienstvak. Bij keuring, selectie en opleiding is voorzichtigheid geboden bij het stellen van eisen waaraan bij de toekomstige functieuitvoering niet of alleen bij hoge uitzondering behoeft te worden voldaan. Het op peil brengen van de fysieke gesteldheid van de vrouwelijke militair zal minder geforceerd moeten zijn en beter gericht moeten zijn op het voorkomen van blessures. Daarbij zal rekening moeten worden gehouden met specifieke tekortkomingen. Bij de opleiding is een goede opbouw noodzakelijk, omdat niet verlangd kan worden dat iedereen alles in één keer kan.

Concluderend kunnen we ten aanzien van de effectiviteit van de krijgsmacht en de rol van de vrouw in die krijgsmacht stellen dat het niet te verwachten is dat de effectiviteit van de krijgsmacht geschaad wordt door de gemiddeld fysiek mindere kwaliteiten van de vrouw. Eigenlijk dienen we hier ook niet te spreken over de kwaliteiten van de vrouw, maar over de kwaliteiten van de fysiek minder sterke mens.

Behalve de weerstanden die zijn gebaseerd op de effectiviteit van de krijgsmacht, worden er bij de vrouw in de krijgsmacht ook problemen gezien, die te maken hebben met de vrouw-man relatie, het altijd aanwezige spanningsveld tussen de seksen. De invloed van de verschillen in fysiek, psychisch en biologisch opzicht tussen man en vrouw wordt door sommigen zo groot geacht dat uiteindelijk een negatieve invloed op de werkprestaties wordt gevreesd. ${ }^{43}$ De vraag is echter of deze negatieve invloed op de werkprestaties of inefficiëntie werkelijk aanwezig is en hoe deze inefficiënties geminimaliseerd kunnen worden. De doelmatigheid van een vrouwelijke militair ten opzichte van een mannelijke militair komt neer op het vergelijken van de kosten van deze militairen in een gelijke functie.

Tabel 6.1. Redenen van absentie, uitgedrukt in dagen per jaar. 44

\begin{tabular}{|l|l|l|}
\hline Reden van absentie & $\begin{array}{l}\text { Gemiddeld verlies aan } \\
\text { dagen: vrouwen. }\end{array}$ & $\begin{array}{l}\text { Gemiddeld verlies aan } \\
\text { dagen: mannen. }\end{array}$ \\
\hline 0,12 \\
\hline $\begin{array}{l}\text { Drugs } \\
\text { Ongeoorloofde af } \\
\text { wezigheid }\end{array}$ & 0,09 \\
\hline Desertie & 0,02 \\
\hline Abortus & 0,05 \\
\hline Zwangerschap & 0,07 \\
\hline Totaal & 0,03 \\
\hline
\end{tabular}

Vrouwelijke militairen hebben een grotere behoefte aan hygiène dan mannen. Dit heeft een biologische oorsprong, waaraân de krijgsmacht zich dient aan te passen. Zo dienen gebouwen en kleding aangepast te worden aan de behoeften van de vrouwe-

\footnotetext{
43 Zie MRK-advies, nr, 7, blz. 33 .

44. Data van de U.S Nawy, maart 1977, in: Martin Binkin en Shirley 1. Bach, Women and the Militury, Brookings lnstitution, Washington 1977 , blz. 63 .
} 
lijke militairen. Vrouwen kunnen zwanger worden en kunnen bovendien last hebben van menstruatiepinen. Dooi" dit biologische verschil met mannen zou verwacht kunnen worden dat vrouwen vaker absent zijn dan mannen. Deze absentie zou de paraatheid van de krijgsmacht kunnen aantasten. Doch uit de statistieken van de Marine van de Verenigde Staten (Tabel 6.1) blijkt dat de absentie van mannen tweemaal zo hoog ligt als de absentie van vrouwen.

Vrouwen kennen een betere discipline en zijn vaak veel nuchterder wanneer het gaat om het verdragen van spanningen in het werk. Vrouwen zijn vaak beter dan mannen in staat het gehele contract uit te dienen, wat een besparing oplevert aan wervings- en opleidingskosten. De genoemde voorbeelden laten zien dat het niet zozeer gaat om een toename van de kosten bij een grotere aanwezigheid van vrouwen in de krijgsmacht, maar om een verandering van kosten. De relevante vraag is dan, hoeveel het de krijgsmacht zal kosten of opleveren indien vrouwen woor mannen worden gesubstitueerd. Indien er meer vrouwen in de krijgsmacht komen, kunnen de cijfers voor de vrouwen weer verslechteren en zullen de eventueel aanwezige kostenverschillen weer verminderen. Aan de andere kant zullen de vrouwen de plaats in nemen van de minst geschikte mannen, wat weer een kostenbesparing oplevert. Zolang de marginale kosten van een extra vrouw minder zijn dan de marginale kosten van een man waarvan ze de plaats inneemt, zal de substitutie geld opleveren zelfs indien de gemiddelde kosten van vrouwen daardoor toenemen.

De belangrijkste financiële consequentie van een uitbreiding van het aantal vrouwen in de krijgsmacht blijft echter de uitbreiding van de basis voor het arbeidsianbod. Op deze wijze kan aan de behoefte aan militairen worden voldaan zonder dat salarisverhogingen nodig zijn. Het succes van een vrijwilligersleger zal ondermeer af te lezen zijn aan de mate waarin de krijgsmacht erin slaagt vrouwelijke militairen aan het werk te krijgen binnen de organisatie. Dit betekent dat er een duidelijk integratieproces uitgevoerd moet worden. Dit integratieproces heeft pas kans van slagen indien de bestaande organisatie goed wordt voorbereid op en begeleid in het proces van samen op gelijke voet functioneren.

In een integratieproces van vrouwen in de krijgsmacht doen zich de zelfde verschijnselen voor als bij inhaalmanoeuvres van alle achtergestelde groepen. Andere groepen voelen zich daardoor bedreigd in hun positie en grijpen ieder argument aan om zich tegen die ontwikkeling te verzetten. Ook dit is een belangrijke bron van problemen bij de integratie van de vrouw in de krijgsmacht. De vrouw loopt de kans te vereenzamen in de mannenwereld van de krijgsimacht.

Tot nu toe hebben we gekeken naar de vrouw als individu, maar we moeten niet vergeten dat deze viouw wel in een groep moet functioneren. Het is dus ook noodzakelijk het groepsgedrag onder de loep te nemen. Binkin en Bach onderscheiden bij het groepsgedrag twee contrasterende scholen van gedachten. ${ }^{45}$ Eén school impliceert dat de integratie van vrouwen in gevechtseenheden of aan boord van schepen voor significante problemen kan zorgen. De andere school voorziet veel minder problemen.

De eerste school onderschrijft de hypothese dat mannen zich samentrekken in sociale groepen, waarvan vrouwen uitgesloten zijn. Dit zou speciaal zo zijn in instituties waar het gaat om de controle van zaken die indruisen tegen de sociale orde, zoals de

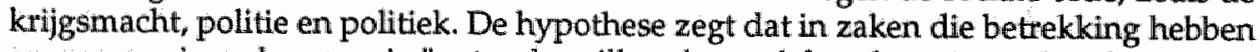
op georganiseerde agressie "not only will males and females reject other females as potential leaders and defenders, but that males will reject females as colleagues".

45 Binkin an Bach, bla. $89 \mathrm{er}$. 
Indien dit zou kloppen, zou de aanwezigheid van vrouwen de effectiviteit van een eenheid kunnen beïnvloeden. Dit zou vooral kunnen gebeuren in eenheden die een macho-imago hebben. Deze eenheden trekken vaak vrijwilligers aan, omdat de eenheid dit imago heeft. Door de introductie van vrouwen in zo'n eenheid kan ook het type vrijwilliger veranderen en daarmee de groepscohesie verminderen en dus de gevechtskracht. De introductie van vrouwen op de schepen bij de Koninklijke Marine heeft tot discussies geleid die veel lijken op de hiervoor gestelde hypothese. Uit onderzoek van zowell de Maatschappelijke Raad voor de Krijgsmacht ${ }^{46}$ als Binkin en Bach $^{47}$ blijkt dat in de praktijk geen sprake is van een verlies aan gevechtskracht.

"De Raad acht de nadelige invloed van drankmisbruik op de juiste tenuitvoerlegging van de operationele taak veel gemakkelijker aantoonbaar en ook veel ernstiger dan de invloed daarop van manvrouw-relaties en wat daar zoal mee samenhangt. Niettemin zijn de geluiden tot drooglegging in de marine heel wat zwakker dan de roep om wrouwen aan de wal te laten."

De tweede school hecht minder belang aan de invloed van sociale groepsvorming. Ervaringen uit de Vietnam- en de Korea-oorlog hebben de weg vrij gemaakt voor een pad dat weer van de groepsvorming afgaat in de richting van een meer individualistische denkwijze. ${ }^{48}$ Volgens deze denkwijze, die gebaseerd is op de snelle aflossingen in gevechtseenheden gedurende de oorlogen in Vietnam en Korea, is het persoonlijke zelfbelang van een soldaat belangrijker dan verplichtingen van deze soldaat aan de samenleving:

"The ullimate standard of combat behavior rests on each individual's fight for survival", 49

De school gaat ervan uit dat de mannelijke ethiek die verbonden is aan gevechtsfuncties overdreven wordt. "Mannelijkheid" en "fysieke hardheid" mogen dan wel vrijwilligers in gevechtsfuncties krijgen, hun belang neemt drastisch af zodra deze vrijwilligers geconfronteerd worden met zaken als leven-en-dood. Deze interpretatie wordt gesteund door de ervaringen zoals beschreven door de Maatschappelijke Raad voor de Krijgsmacht. Ook strookt deze opvatting met de ervaringen van de Emancipatiecommissie van de Gemeentepolitie Den Haag. Uit het rapport "Vrouw in de ME" blijkt dat vrouwen als het er werkelijk om gaat veel nuchterder optreden dan mannen. In de krijgsmacht komen situaties als bij de politie minder vaak voor, doch de ervaringen in de Verenigde Staten zouden de stelling kunnen steunen dat groepsgedrag minder van belang is als het er werkelijk om gaat.

In het algemeen kunnen we zeggen dat de theorie van het groepsgedrag niet goed opgaat. Maar wat is het geval indien het aantal vrouwen in een groep erg klein is, omdat slechts een klein aantal vrouwen geïnteresseerd is in een functie in die groep. Binkin en Bach stellen in deze:50

"Research suggests that as long as women are in the minority, men will continue to view them according to preconceived stereotypes and to fullfill their own need to project the malle image. This woutd tend to isolate women, keep the male group in conflict with them, and thus reduce overall group productivity.

\footnotetext{
46. MRK-advies nr. 7, blz. 35.

47 Birkin en Bach, blz 93-95.

48 Zie hiervoor ondermeer Charles C. Moskos, Ir., The American Enlisted Man, blz.. 143-146.

49 Ibid., blz.145.

50 Binkin en Bach, blz. 92.
} 
Also meriting attention are the possible effects of social alliances and sexual pairings an unit performance. Integration studies found generally that, while the ideal mix was not surprisingly half and half, social problems were less likely to develop when the ratio of men to women was lower than three to one. Above that threshold, according to the researchers, some women tended to assume a "superwomani role and to make more male friends than they normally would, while the men tended to socially reject them as inferior".

De MRK beschouwt het kleine aantal vrouwen in een groep ook als een probleem. $\mathrm{Zij}$ geeft als oplossing over te gaan op quoteringsmaatregelen: plaatsing van relatief grote groepen vrowwen in bepaalde delen van het krijgsmachtbedrijf. ${ }^{51}$ Dit voorkomt tevens problemen als "vereenzaming" en een "onvoldoende belangstelling" van mannelijk kader.

In Nederland staan alle functies in de krijgsmacht open voor vrouwen. De praktische invulling van dit gegeven blifft echter uit. Gedurende reeds vele jaren voldoet de Nederlandse krijgsmacht niet aan de eis om ongeveer $8 \%$ van het militaire personeelsbestand uit vrouwen te laten bestaan. Dit komt voornamelijk omdat vrouwen zich eenzijdig moeten aanpassen aan de krijgsmacht, waardoor zij worden afgeschrikt en er niet genoeg vrouwen overblijven om een ook voor vrouwen aantrekkelijk klimaat te laten ontstaan. Doordat de krijgsmacht zich niet aanpast aan de vrouw worden vrouwen de mogelijkheden ontnomen om te profiteren van de goede dingen van de krijgsmacht, zoals werkervaring en training op diverse terreinen. De rol van de vrouw zal in grote mate samenhangen met de mate waarin nationale instituties bereid zijn mee te werken aan de integratie van de vrouw in de krijgsmacht.

De politiek en de krijgsmacht leken in 1982 hun will al te hebben getoond door alle functies open te stellen voor vrouwen. Doch zij lieten de dienstplicht in takt. Door het bestaan van de dienstplicht is de integratie van de vrouw in de krijgsmacht tot mislukken gedoemd, omdat de krijgsmacht geen prikkels heeft zich daadwerkelijk aan te passen aan de behoeften op velerlei terrein van de fysiek zwakkere mens, waartoe de vrouw voor het merendeel behoort.

Integratie van de vrouw in de krijgsmacht is ondermeer een ergonomisch probleem dat pas naar voren komt, indien de prikkels voor die ergonomische investeringen ook daadwerkelijk naar voren komen. Het instellen van een vrijwilligersleger brengt deze prilkkels aan het licht en zal er hopelijk ook voor zorgen dat het integratieproces daadwerkelijk van de grond komt. De percentages vrouwen in de Verenigde Staten en Groot-Brittannie, Ianden met een vrijwilligersleger, geven daartoe hoop. De Verenigde Staten kende in 1984 rond de 9 procent vrouwen en GrootBrittannie ongeveer 6 procent, terwijl Nederland in 1984 niet verder kwam dan ongeveer $2 \% .52$ op 1 maart 1991 is dit percentage gestegen tot $5,2 \%$ van het bestand aan beroepsmilitairen, of ongeveer $2,8 \%$ van het totale bestand aan militairen. Dit percentage stabliseert zich en voldoet daarmee nog lang niet aan de gestelde norm van ongeveer $8 \%$

In een vrijwilligersleger zijn mensen schaars, en dienen zij volop aandacht te krijgen. Dit geldt in het bijzonder voor de vrouwen. Vrouwen maken $50 \%$ van onze bevolking uit en een juiste integratie van de vrouw in de krijgsmacht zorgt voor een grote uitbreiding van de basis van het arbeidsaanbod en een dito vermindering van de salarislasten voor de gehele organisatie. De vrouw in de krijgsmacht is niet slechts een mannenprobleem, zoals de MRK stelt. Het is vooral een probleem dat samenhangt met het bestaan van de dienstplicht.

\footnotetext{
$51_{\text {MRK-advies nu } 7, \text { blz. } 66 .}$

52 Tdem, ble. 101.
} 


\section{$\$ 6.4$. De vraag naar beroepsmilitairen}

In het rapport van de commissie-Meijer speelde de vraag naar vrijwilligers een onderschikte rol. In het arbeidsmarktonderzoek dat de commissie liet verrichten werd uitgegaan van de vervanging van één dienstplichtige door eén beroepsmilitair. Het onderzoeksteam, dat het arbeidsmarktonderzoek verrichtte, kwam op basis van haar resultaten tot de conclusie dat:

\footnotetext{
"Vergroting van het geïnteresseerde aanbod en het beter bereiken wan het aanbod kan betekenen dat de behoefte nipt wordt vervuld, maar voor een overschakeling naar een kadervrijwilligerskrijgsmacht is het nodig dat defensie haar behoefte en procedures kritisch tegen het licht houdt. ${ }^{53 "}$
}

In dit hoofdstuk hebben we het aanbod van vrijwilligers reeds uitwoerig onder de loep genomen. Ook zijn de selectieprocedures besproken en nu is het de beurt aan de behoefte of vraag naar vrijwilligers. De vraag naar vrijwilligers, of beroepsmilitairen zoals we ze in deze paragraaf verder zullen noemen, is uitermate belangrijk in een vrijwilligersleger. Omdat arbeidskrachten schaars zijn is het des te noodzakelijker om te zien hoeveel militairen er nu daadwerkelijk nodig zijn. Op deze wijze kunnen we tevens achterhalen, welke kosten dienstplicht nog meer meebrengt naast de kosten die reeds eerder aan het licht zijn gekomen.

Zoals we reeds in hoofdstuk 5 hebben gezien is de vraag naar nieuwe militairen op lange termijn een dalende functie van de kosten van militaire arbeid. Indien nieuwe militairen relatief duur worden ten opzichte van andere "inputfactoren" in de krijgsmacht, zullen er minder nieuwe militairen en meer andere "inputfactoren" gevraagd worden. In figuur 6.3. komt de vraag naar nieuwe militairen overeen met de curve DD. Op korte termijn is de behoefte relatief constant, omdat het voor een gegeven krijgsmachtstructuur enige tijd duurt voordat de mix van produktiefactoren zich aangepast heeft. In figuur 6.3. wordt dit weergegeven door de lijn RR. Het aanbod van vrijwilligers wordt weergegeven door de curve SS. Het belang van de simpele figuur 6.3. is dat in deze figuur de essentie van het vrijwilligersleger is weergegeven. Figuur 6.3 laat zien dat de "haalbaarheid" van een vrijwilligersleger voortkomt uit zowel het aanbod van vrijwilligers als de vraag naar vrijwilligers.

Deze paragraaf heeft tot doel te laten zien, hoe de behoefte aan militairen geminimaliseerd kan worden. In termen van figuur 6.3. betekent dit dat de DD-of RRcurve zover als mogelijk naar links ( $R^{*} \mathbb{R}^{*}$ ) zal moeten verschuiven, of er zal een verschuiving langs de DD-curve naar boven dienen te geschieden. Deze laatste verschuiving is in hoofdstuk 5 uitvoerig a an de orde gekomen. Door de afschaffing van de dienstplicht nemen de kosten van militairen toe. Door deze kostentoename ontstaat een substitutieproces, waarbij militairen vervangen worden door burgers en kapitaal. Bij de overschakeling van een dienstplichtigenleger naar een vrijwilligersleger zijn deze substituties het belangrijkst, doch ook na dit substitutieproces blijft het beperken van de behbefte aan nieuwe militairen een zaak van de hoogste orde.

531 Commissie Mejjer, Naar dienstplicht nieuwe stijl, Arbeidsmarktonderzcek, Den Haag, 1992, blz. 49. 


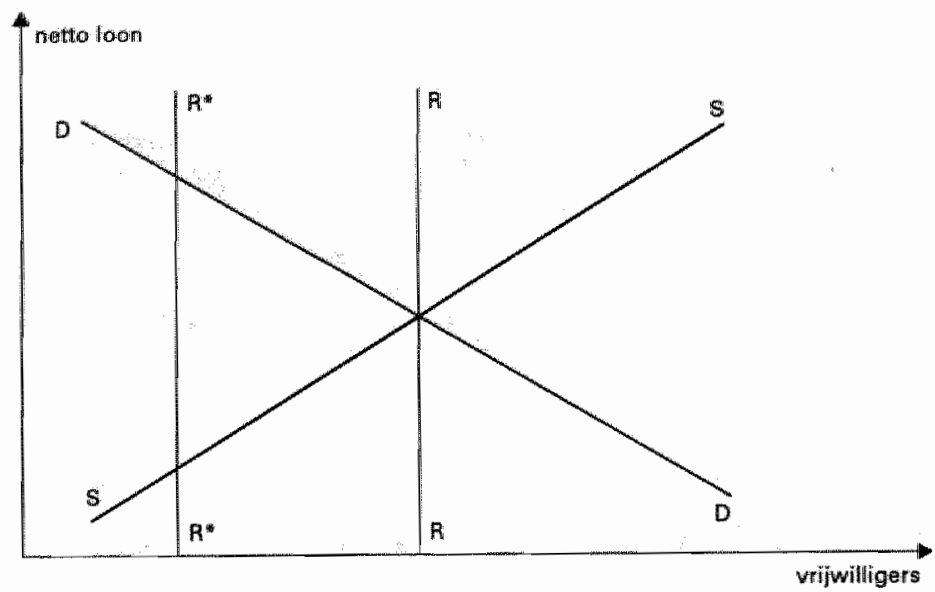

figuar 6.3 Vraagen atabod beroepsmilitairen

Ieder jaar vallen ex militairen uit het personeelsbestand omdat ze sneuvelen in een oorlog, met pensioen gaan, hun contract afloopt of omdat ze ontslag nemen.

In hoofdstuk 5 hebben we gezien dat de afschaffing van de dienstplicht raast de hiervoor genoemde subsituties ook een substitutie van onervaren naar ervaren militairen tot stand brengt. We zijn daar ook ingegaan op enige nadere aspecten van de mix van ervaren en onervaren militairen. Dit zal in de valgende subparagraaf worden uitgebreid.

\section{\$6.4.1. De mix van ervaren en onervaren militairen}

Eén van de centrale doelstellingen in het personeelsbeleid van de krijgsmacht is altijd geweest, dat een jonge krijgsmacht de beste krijgsmacht is. Waarom eigenlijk? Bij de bepaling van het leeftijdsprofiel spelen diverse factoren een roll.

Allereerst is er de constatering dat de krijgsmacht altijd een premie heeft gezet op een "jonge en krachtige" krijgsmacht. Dit komt omdat het militaire beroep een hoge mate van fysieke geschiktheid vereist. Dit concept geldt niet alleen voor de gevechtsfuncties, maar wordt tevens witgebreid naar de niet-gevechtsfuncties. De reden achter deze gedachte is dat de niet-gevechtsfuncties in vredestijd worden gezien als een arbeidspool om gevechtsfuncties in oorlogstijd op te vullen. Dit vereist een minimum a an fysieke geschiktheid zonder veel uitzonderingen. Hierin weerspiegelt zich de gedachte dat een fittere krijgsmacht ook een effectievere krijgsmacht is. Des te jonger het personeelsbestand, des te beter.

Ten tweede zit het militaire hiërarchische personeelsmanagementsysteem (het "up-or-out" systeem) zo in elkaar dat er een snelle opeenvolging van mensen in een 
bepaalde functie noodzakelijk is. Dit creëert een grote behoefte aan jonge mensen van wie verlangd wordt dat ze niet langer dienen dan eén contractperiode.

Het derde argument voor een jonge krijgsmacht is dat een jonge krijgsmacht altijd gezien wordt als een goedkope krijgsmacht en ten vierde zorgt de snelle opeenvolging van jongeren in de krijgsmacht voor een vergroting van de basis voor het mobillsabele bestand. Tenslotte geldt als argument voor een jonge krijgsmacht dat een militair systeem waarin een groot aantal jongeren tijdelijk dienen een voordeel voor de gehele maatschappij is.

De roep om een jonge krijgsmacht klinkt niet alleen in Nederland. Toch doet de idee dat een jonge krijgsmacht ook de beste krijgsmacht is op het eerste gezicht vreemd aan. In de burgermaatschappij speelt ervaring juist een belangrijke rol in het produktieproces en speelt de verhouding tussen ouderen en jongeren veelal een ondergeschikte rol. Ook de krijgsmacht is een organisatie van kapitaal en arbeid, waarin de factor ervaring of "human capital" zeker niet uitgevlakt mag worden.

De krijgsmacht dient gevechtskracht te produceren, en voor deze gevechtskracht dient zij zowel over fysiek kapitaal, human capitall als arbeid te beschikken. De fixatie op een jonge krijgsmacht en dus de factor arbeid is daarom op zijn minst naïef te noemen, omdat het fysieke kapitaal en het "human capital" in de huidige krijgsmacht een minstens zo belangrijke rol spelen.

Des te jonger de krijgsmacht, des te onervarener is deze krijgsmacht. Hoe onervaren deze krijgsmacht feitelijk is, is echter moeilijker aan te geven. Conventionele militaire kracht is altijd gemeten in termen van kwantiteit en nooit in termen van kwaliteit. ${ }^{54}$ In hoofdstuk 5 hebben we gezien dat een ervaren krijgsmacht met veel minder mensen toe kan om dezelfde gevechtskracht te behouden. Robert S. Gay concludeerde dat 100 man met een ervaring van 4 jaar hetzelfde werk kunnen doen als 180 onervaren mannen zonder dat een verlies aan gevechtskracht te verwachten is. Indien we de hiervoor besproken punten voor een jonge krijgsmacht nader onder de loep nemen, blijkt dat bij de meeste punten enige aanmerkingen zeker op zijn plaats zijn. En dat geldt niet alleen voor het punt ervaring.

Militair personeel beschouwt de rang en de vooruitgang door de rangen in het hiërarchische systeem, als de belangrijkste maatstaf van individuele vooruitgang. Bij het personeelsbeleid wordt dan ook een grote nadruk gelegd op het promotiesysteem. De rang fungeert als een soort vaardigheidsindex zonder dat echt wordt gekeken naar verschillen in operationele taken. Op zich beschouwd betekent een personeelssysteem dat voornamelijk gefixeerd is op de vooruitgang door de rangen nog niet dat er een. jonge krijgsmacht dient te zijn. Maar dit wordt anders indien we het rangenstelsel zien in combinatie met het "gesloten karakter" van het militaire systeem.

In de burgermaatschappij komen werknemers op elk niveau binnen in organisaties en verlaten zij die organisaties ook weer op verschillende niveaus. In de krijgsmacht is dit echter anders. Vrijwel alle militairen komen aan de voet van de hiërarchische militaire organisatie binnen, worden door de krijgsmacht opgeleid, en vervolgen hun weg verder door de organisatie naar boven. Daar de hiërarchische militaire organisatie aan de top steeds smaller wordt, betekent een opwaartse stroming door de organisatie dat ervaren mensen de orgąnisatie moeten verlaten en vervangen worden door onervaren mensen. Dit gebeurt simpelweg omdat in rang niet meer omhoog kan worden gegaan. Naar de kwaliteit van het werk wordt minder gekeken. Het is "up-orout" met als gevolg dat een organisatie als de krijgsmacht een groot aantal jongeren in dienst moet nemen en zij automatisch jonger in personeelssamenstelling wordt.

54.Zie ook hoofdstulk 2, paragraaf 1. 
Deels is de jonge krijgsmacht daarom ook te verklaren met de principes van de markt. De krijgsmacht kan simpelweg niet concurreren met de markt in het gevecht om de ervaren man, omdat betalings- en promotiemogelijkheden gekoppeld zijn aan de diensttijd in de krijgsmacht en niet aan de vaardigheden. Het resultaat is dat de krijgsmacht wel genoodzaakt is jonge onervaren krachten in dienst te nemen. 55

Een jonge krijgsmacht wordt ook gezien als een goedkope krijgsmacht. Deze stelling was prominent aanwezig tijdens de dienstplicht. Hierbij kwamen alle elementen naar voren die wij reeds eerder vele malen gezien hebben. Tot nu toe hebben we voortdurend moeten concluderen dat dienstplicht de kosten van de krijgsmacht niet verlaagt. Dienstplicht verhult de kosten van de krijgsmacht.56 De kosten zijn wel degelijk aanwezig, maar worden niet gedragen door diegenen die de jonge krijgsmacht propageren.

Tenslotte gelden er sociale argumenten voor een jonge krijgsmacht. Een grote "turnover" aan jongeren zou een bescherming zijn tegen een separate ontwikkeling van de millitaire ethiek. Zonder al te veel in detail te treden, dit gebeurt in hoofdstuk 7 , is het verband empirisch niet aangetoond en valt er over dit verband dan ook veel te twisten.

De stelling dat een jonge krijgsmacht de beste krijgsmacht is, is niet waar. Dit werd ook geconstateerd door de Defense Manpower Commission in de Verenigde Staten in 1976:57

\begin{abstract}
"In noncombat jobs, the maturity, experience, and judgement gained through longer service are more valuable than physical stamina and agility. (...) A longer maximum career is feasible for service members in noncombat jobs, particularly for those in technical and professional jobs. A person in these jobs could normally serve effectively until age 60 . (...) In the field of radar detection, fleet evaluation shows that a destroyer equipped with standard electronic equipment and manned with personnel of excellent ability and experience has the capability of providing the same coverage as about three of the same ships operating in company if these latter are manned with personnel of average ability and experience. According to the committee: the effect of experience added to training can be seen in the field of guided missiles in all services. In general, missiles prepared and used by a group with a few years experience perform twice as effectively as missiles prepared by a group with similar training but no backlog of experience".
\end{abstract}

Door de technologische en organisatorische ontwikkelingen binnen de krijgsmacht zouden expertise en ervaring de doorslag moeten geven in het personeelsbestand. Doch de werkelijkheid van alle dag in de krijgsmacht is moeilijk om te bouwen naar een situatie die gelijk is aan de stiuatie in de burgermaatschappij. Een burgermaatschappij die laat zien dat verbetering in het gebruilk van personeel aanzienlijk kan zijn, waardoor de in en uitstroom van personeel danig vermindert.

Indien we de argumenten voor een jonge krijgsmacht nader beschouwen, is een jonge krijgsmacht eerder een middel dan een doel op zich. Een jonge krijgsmacht is een rechtvaardiging van de dienstplicht en het personeelsonvriendelijke personeelsmanagementsysteem. Dienstplicht zorgt voor een vrij aanbod van jongeren, wat gerechtvaardigd wordt door te stellen dat een krijgsmacht wel jong moet zijn wil zij effectief kunnen werken. Het personeelsmanagementsysteem dat de

\footnotetext{
${ }^{55}$ Gelulkkig laat de krijgsmacht de laatste jaren een verschuiving zien in haar promotiebeleid van diensttijid naar Faardigheden.

56 Zie hoofdstuk 4 en 5 van dit proefschrift.

57Defense Manpiower Commission, Defense Mampower: the Keystrone of National Security, April 1976, in :M. Birkin en $\mathbb{I}$. Kyriakopoulos, Youth or Experience? Marning the Modern Military, Brookings Institution,
Wasthington D.C. blz. 31.
} 
krijgsmacht gebruikt, benadeelt ervaren en oudere militairen, waardoor zil plaats moeten maken voor jongere militairen. Ook dit wordt gerechtvaardigd door te stellen dat de krijgsmacht jong moet zijn. Beide rechtvaardigingen zijn dubieus en kosten de krijgsmacht en de maatschappij veel geld.

\section{\$6.4.2. Dienstplicht en de dood58}

In een vrijwilligersleger is het noodzaak dat de behoefte aan nieuwe militairen zo laag als mogelijk wordt gehouden. Dit betekent dat de krijgsmacht ervoor dient te zorgen dat reeds aanwezige militairen zolang als mogelijk in dienst worden gehouden. Dit vraagt ondermeer om een vernuftig personeelsbeleid. Toch is uitval van personeel in een krijgsmacht niet te vermijden. De krijgsmacht is een geweldsorganisatie en indien deze in actie komt is het onvermijdelijk dat er slachtoffers vallen.

Ten tijde van de Koude Oorlog en het dienstplichtigenleger dat Nederland toen kende, was de krijgsmacht zo ingericht dat een snelle opvolging van personeel in een oorlog mogelijk moest zijn om de oorlogsposities staande te houden. In tegenstelling tot de krijgsmacht van het Verenigd Koninkrijk kende de Nederlandse krijgsmacht een grote mobilisabele component. De Britten kennen een relatief kleinere mobilisabele component, omdat zij uitgaan van de gedachte dat een leger alleen in uiterste nood als verdedigingsinstrument ingezet kan worden. Daar de Britten een vrijwilligersleger kennen speelt bij deze gedachte het schaarstebegrip een belangrijke rol. In een vrijwilligersleger zijn militairen schaars en kan het voeren van een niet noodzakelijke oorlog leiden tot het verdwijnen van het totale leger indien er veel slachtoffers vallen.

In Nederland is weinig van deze Britse gedachte te merken. Per functie worden in het Eerste legerkorps 5 a 6 mensen noodzakelijk geacht om de verliezen aan personeel goed te kunnen maken. Het verschil tussen de Britse en Nederlandse opvattingen met betrekking tot dit onderwerp is theoretisch goed te verklaren en heeft zijn basis in het verschil tussen een vrijwilligersleger en een dienstplichtigenleger en de kans op een oorlog met beide legers.

Militairen zijn voorbestemd om in het geval van een oorlog het eigen land te verdedigen. Oorlogen zijn zeldzame gebeurtenissen en hangen veelal samen met het bestaan van een kritische situatie. Wat nu precies een kritische situatie is, is vaak onduidelijk. Daarom spreken we af dat een kritische situatie zal bestaan wanneer de machthebbers van een land zeggen dat zo'n situatie bestaat. Het institutionele bestel van een land waarmee collectieve beslissingen worden gemaakt is daarbij bepalend of een bepaalde situatie nu well of niet als kritiek wordt beschouwd. Hieruit volgt dat indien we een situatie kritiek vinden onder eén bepaald institutioneel bestel dit niet automatisch betekent dat deze situatie kritiek blijft, indien het institutionele bestel wijzigt. Bij een veranderde omgeving zullen collectieve beslissingen misschien ook veranderen.

In paragraaf 5 van hoofdstuk 2 en paragraaf 4 van hoofdstuk 3 zijn we bij het nemen van collectieve beslissingen uitgegaan van het mediane kiezersmodel. In het vervolg van deze subparagraaf zal worden voortgegaan met dit model. In hoofdstuk 2 bestond ons collectieve besluitvormingsproces uit een keuze tussen boter en kanonnen, waarbij we een continue variabiliteit veronderstelden ten aanzien van de hoe-

58 Deze paragraat is gebaseerd op het werk van Richard E. Wagner , Conscription, Voluntary Service and Democratic Fiscal Choice, in: Buchanan and Tollison, Theory of Public Choice, 1972, blz.136-152. 
veelheid kanomen. Beslissingen over oorlogvoering zijn echter geen continu proces, maar meer binair van aard. Of we gaan wel oorlog voeren, of we doen het riet. Of zullen we door gaan met een oorlog, of zullen we de vijandelijkheden staken waar we eerder toe besloten hadden.

Bij het onderzoeken van collectieve keuzen over oorlog, moeten we dus eigenlijk kijken naar de drempel tussen positieve en negatieve beslissingen. Een positieve beslissing om een oorlog te voeren zal niet worden veranderd door een marginalle verandering in de voorkeuren, maar zal slechts worden herzien indien de afname in voorkeur woor de oorlog een bepaalde drempel overschrijdt. De relevantie van het mediane kiezersmodel, een model met continue variabiliteit, lijkt in dit geval klein. Doch dit is niet geheel waar. De relevantie van dit soort modellen ligt in de vergelijking van de uitwerkingen die verschillende instituties hebben bij de mogelijke overschrijding van de drempel om wel of niet oorlog te voeren of met een oorlog te stoppen.

Door het verschil tussen alternatieve instituties in een omgeving van voortdurende verandering te onderzoeken, kan de analyse misschien iets zeggen over de relatieve waarschijnijikheid dat de drempel overschreden zal worden. De alternatieve instituties betreffen in dit geval natuurlijk een dienstplichtigenleger of een vrijwilligersleger.

Bij een onderzoek naar de effecten van dienstplicht op het voeren van een oorlog zijn vier mogelijke situaties te onderscheiden. Enerzijds maken we een onderscheid tussen situaties waarin een oorlog reeds plaatsvindt en situaties waarin dit niet het geval is. Daarnaast maken we een onderscheid tussen situaties waarin de voorkeur voor oorlog toeneemt en situaties waarin de voorkeur voor oorlog afneemt. Dus een oorlog kan momenteel plaatsvinden, waarbij de voorkeur deze oorlog voort te zetten toeneemt of afneemt. Of er is sprake van vrede en de dreigingen (voorkeur voor oorlog) nemen af of nemen toe.

Van de vier mogelijke situaties zijn er twee analytisch interessant, omdat deze de mogelijkheid met zich meebrengen dat de drempel van wel of geen oorlog overschreden kan worden. Deze twee zijn de vermindering van de voorkeur voor oorlog terwijl een oorlog plaatsvindt, of een situatie van toenemende dreiging in vredestijd. Slechts de eerste situatie zal hier nader besproken worden, omdat de analyse van de tweede situatie symmetrisch is aan de analyse van de eerste situatie.

We veronderstellen dus dat we momenteel verkeren in een situatie van oorlog. Een situatie die door een normal democratisch besluitvormingsproces to stand is gekomen, Sinds het besluit tot oorlogsvoering genomen is, zijn de voorkeuren voor deze oorlog bij een deel van de burgerbevolking echter afgenomen zonder dat de voorkeuren bij het andere deel van de burgerbevolking zijn toegenomen. In ons mediane kiezersmodel betekent dit alleen een verandering, indien de voorkeuren van de mediane kiezer ook veranderd zijn. Is dit niet het geval dan verandert er niets. Toch is dit niet te allen tijde $z o$.

Het wordt namelijk anders indien we het onderscheid tussen een dienstplichtigenleger en een vrijwilligersleger bekijken. Bij een vrijwilligersleger zal de beslissing om een oorlog voort te zetten onder druk komen te staan, indien een deel van de mensen met een verminderde voorkeur voor de oorlog voortkomt uit de bevolkingsgroep welke militaire arbeid aanbiedt. Dit geldt zelfs indien er geen veranderingen waar te memen zijn in de voorkeur voor oorlog bij de mediane kiezers. Indien de situatie van het land als minder bedreigend wordt ervaren door de mensen die de militaire arbeid verzorgen, zullen deze mensen alleen de oorlog voortzetten, indien zij voor deze voortzetting gecompenseerd worden. Met andere woorden: er zal een ho- 
ger loon geboden moeten worden aan nieuwe vrijwilligers om de noodzakelijke hoeveelheid arbeid te krijgen. Mensen zijn eerder bereid zich als vrijwilliger aan te melden tegen een bepaald loon indien ze overtuigd zijn van het feit dat de veiligheid wan een land echt in gevaar is, dan dat ze twijfels hebben of dit inderdaad het geval is.

Hogere lonen voor militairen betekent tevens een hogere belasting voor de rest van de bevolking, omdat de noodzakelijke loonsverhoging op de eén of andere manier betaald moet worden. In een dienstplichtigenleger hebben we dit mechanisme niet omdat dienstplichtigen gedwongen worden en dus ook geen looneisen kunnen stellen.

Indien de voorkeuren voor de oorlog niet veranderen in de bevolkingsgroep die de militaire arbeid levert, maakt het geen verschil voor de oorlogsbeslissing of we nu te maken hebben met een dienstplichtigenleger of een vrijwilligersleger. Echter, indien de bevolkingsgroep die de militaire arbeid levert wel een verandering in de voorkeur voor de oorlog laat zien, is het onderscheid tussen het dienstplichtigenleger en het vrijwilligersleger wel van belang. Door de extra belastingen zal de oorlog duurder worden in het geval van een vrijwilligersleger. Des te groter de stijging van de belasting, des te groter is de kans dat de mediane kiezers de oorlogsbeslissing willen terugdraaien. Hoewel een toename in belastingen niet voldoende hoeft te zijn om de drempel van de oorlogsbeslissing te passeren, is het waarschijnlijker dat dit sneller gebeurt in het geval van een vrijwilligersleger, omdat een dienstplichtigenleger de koppeling naar de bevolking met behulp van belastingen niet kent.

In het geval van een vrijwilligersleger zijn er dus twee mechanismen waarlangs een oorlogsbeslissing veranderd kan worden: de voorkeur voor de oorlog en de prijs van de oorlog in de vorm van belastingen. In het geval van een dienstplichtigenleger hebben we slechts het eerste mechanisme en ontbreekt de impliciete kosten-baten analyse.

Samenvattend kunnen we stellen dat dienstplicht de mogelijkheid van een oorlog zal vergroten. Indien de leden van een democratische gemeenschap verschillen in hun bereidheid tot een oorlog, zal een beslissing voor een oorlog waarschijnlijker zijn in het geval van een dienstplichtigenleger, dan in het geval van een vrijwilligersleger. Dit komt omdat de budgettaire kosten van een oorlog onder dienstplicht lager zullen zijn.

Een situatie van oorlog of "nationale noodtoestand" kan dus niet onafhankelijk bepaald worden van het institutionele bestel dat een land heeft. Democratische processen kunnen leiden tot het declareren van een noodtoestand onder een bepaald institutioneel bestel. Een noodtoestand die onder een ander institutioneel bestel nooit bestaan had.

In de praktijk van alle dag vinden we deze denkbeelden terug bij het Britse vrijwilligersleger. De Britten zijn van mening dat een leger slechts dient ter verdediging van vitale doelen en dat een samenleving zich wel twee keer moet bedenken will zij schaarse militairen opofferen voor een offensieve actie. In een dienstplichtigenleger vinden we deze schaarste riet en zijn de gedachten over oorlog dan ook vaak aggressiever.

Voor de individuele soldaat betekęnt dit dat de sterftekans in een dienstplichtigenleger hoger is dan in een vrijwilligersleger, omdat een vrijwilligersleger minder snel aan een oorlog begint dan een dienstplichtigenleger. Combineren we dit gegeven met het feit dat dienstplichtigenlegers veel arbeidsintensiever zijn dan vrijwilligerslegers, dan komen we tevens tot de conclusie dat in een dienstplichtigenleger ook nog eens veel meer slachtoffers te verwachten zijn dan in het geval van een vrijwilligersleger. 
De behoefte aan rieuwe militairen door de dood zal in een vrijwilligersleger dus minder hoog zijn dan we op basis van het vroegere dienstplichtigenleger konden verwachten. Hoewel dit gegeven voor een $\mathrm{krijgsmacht} \mathrm{in} \mathrm{vredestijd} \mathrm{meer} \mathrm{theoretisch}$ dan praktisch van aard zal zijn, heeft zij wel betekenis voor de grootte van het mobilisabele bestand. De grootte van het mobilisabele bestand zal kleiner zin bij een vrijwilligersleger dan bij een dienstplichtigenleger. Bescherming van het schaarse personeel is een belangrijke doelstelling in een vrijwilligersleger, wat tevens betekent dat minder vervangers noodzakelijk zijn.

\subsubsection{Rangen en beloningen}

In het begin van deze paragraaf hebben we gezien dat de nadruk op een jeugdige krijgsmacht in een vrijwilligersleger niet vol te houden is. Helaas is de krijgsmacht door een second-best personeelsmanagementsysteem wel gedwongen over te gaan tot zo'n jeugdige krijgsmacht. De huidige beleidsstructuren maken het zeer moeilijk te voldoen aan alle vereisten van een vrijwilligersleger. In het laatste deel van deze paragraaf zal daarom worden ingegaan op die instrumenten die ervoor kunnen zorgen dat het personeelsmanagementsysteem van de krijgsmacht wel in overeenstemming is met de vereisten van een modern vrijwilligersleger, zodat potentiële vrijwilligers op een juiste wijze een afweging kunnen maken tussen een baan in de krijgsmacht en een baan in de burgermaatschappij zonder gestoord te worden door institutionele belemmeringen.

De centrale vraag hier is: "Hoe zorgen we ervoor dat militairen zolang mogelijk in dienst van de krijgsmacht blijven". In de literatuur ${ }^{59}$ is voor deze vraag én begrip te vinden: "de retention-rate". Des te hoger de "retention-rate" des te ervarener de krijgsmacht en des te lager de personeelsbehoefte van de krijgsmacht. Het belangrijkste obstakel om de "retention-rate" over de gehele lengte te verbeteren is dat de beloningssystemen in de krijgsmacht gekoppeld zijn aan het rangenstelsel, de duur van het dienstverband in de krijgsmacht en het verzorgingsbeginsel. Omdat deze systemen weinig waarde hechten aan verschillen in beroepsmatige vaardigheden -verschillen waar in de burgermaatschappij juist veel waarde aan gehecht wordt- is het militaire beloningssysteem attractief voor personeel met weinig beroepsmatige vaardigheden, terwijl het er niet in slaagt die mensen tevreden te stellen die de extra vaardigheden juist wel bezitten.

Het eindresultaat is dat de krijgsmacht met die mensen blijft zitten die ze eigenijik best missen kan en de mensen kwijt raakt die ze juist hard nodig heeft. Het millitaire beloningssysteem verschilt in vele aspecten van het beloningssysteem in de burgermatschappij. Twee van deze verschillen vallen daarbij het meest op. De eerste is dat de krijgsmacht haar personeelsleden voornamelijk op basis van rang en dienstjaren uitbetaalt, terwijl in de burgermaatschappij, door een nadruk te leggen op vaardigheid en beroep, meer uitbetaald wordt op basis van geleverde prestaties en mogelijkheden . Daarnaast voorziet de krijgsmacht haar personeel in vele basisbehoeften, zoals voeding, kleding, onderdak en medische zorg. ${ }^{60}$ Dit verzorgingsbeginsel vinden we slechts sporadisch terug in de burgermaatschappij.

\footnotetext{
59zie onder andere : Martin Binkin en Irene Kyriakopoulos, Paying the Modern Military, Brookings Institution, Wrashington D.C. 1981.

60 De Nederlandse praktijk laat zien dat het verzorgingsbeginsel steeds mear op de achtergrond raakt.

Boroepsmilltären wonen veelal buiten de kazeme en betalen voor hun eten. Kleding en medische zorg worden nog wel steods door de krijgsmacht verzorgd.
} 
De reden voor het beloningssysteem dat de krijgsmacht hanteert, heeft een historische oorsprong en raakt aan de wortels van vrijwel ieder militair apparaat. Het militaire establishment is namelijk eerder een instituut dan een beroep. Een burger heeft een beroep en werkt voot een bedrijf. Een militair daarentegen is in het leger en wordt verondersteld daarmee meer een roeping te volgen om een hoger goed te verwezenlijken, dan dat hij puur materieel naar zichzelf kijkt. Het instituut krijgsmacht staat bij de militair voorop en niet zujn persoonlijk belang. Hoewell de beloning van de militair niet te vergelijken is met wat we verwachten kunnen in een normale marktsituatie, wordt dit gecompenseerd door een reeks van sociale voorzieningen en een hoeveelheid psychologisch inkomen. In het geval van problemen op de werkplek zullen de leden van een instituut zich niet zo snel organiseren, maar zullen ze in een persoonlijk onderhoud met hun meerderen proberen hun problemen op te lossen, daarbij vertrouwend op het vermogen van het instituut om zijn eigen problemen op te lossen.61

De krijgsmacht heeft duidelijk haar eigen normen en waarden en wijkt daarmee af van de burgermaatschappij. Deze normen en waarden zorgen ervoor dat een individu volledig ter beschikking staat van de organisatie "which can decide what jobs he does, how and when he does them, what hours he works and the conditions in which he works and lives, entirely without consultation with the employee". 62 Hoe deze individuen te motiveren is echter een vraag waar niet zo snel een antwoord op gevonden kan worden:

\footnotetext{
"Traditionally, money has not been the only answer; service to the country has been more encouraged largerly as a sacrifice to be made out of patriotism or a sense of moral indebtness. Thus military leaders have gone to great lengths to create a professional identity-literally a different way of life in which cohesion, unity of purpose, and reciprocal loyalty are emphasized." ${ }^{\text {:63 }}$
}

Ten einde de eenheid en verbondenheid te bevorderen, worden karakteristieken benadrukt die de leden van de krijgsmacht onderscheider van de rest van de burgerbevolking. Het is dan ook niet verbazingwekkend te constateren dat het militaire beloningssysteem zich aan het model van eenheid en verbondenheid heeft aangepast. Dit beloningsssysteem verplicht zich tot het betalen van hetzelfde loon aan iedereen met dezelfde rang, waarbij het niet uitmaakt of hij of zij nu pantserinfanterist, gewondenverzorger of administratieve kracht is. De impliciete gedachte is namelijk dat iedereen een gelijke bijdrage levert aan de nationale verdediging van een land. Een negatief punt bij deze gelijkheidsgedachte is dat uniformiteit de relevantie van de arbeidsmarkt onderschat, wat kan resulteren in vullingsproblemen.

Van grote invloed op het unieke karakter van het militaire belloningssysteem is het personeelsmanagementsysteem dat de krijgsmacht gebruikt. De krijgsmacht kent een gesloten personeelssysteem, waarbij vrijwel alle personeelsleden aangenomen worden aan de woet van de hiërarchie en verder doorstromen naar boven. Echter, of personeelssystemen en beloningssystemen nu gesloten of open zijn, ze kunnen niet om efficiëntiecriteria heen. Dit geldt zowel voor de marktsector als de overheidssector, omdat efficiëntie in de salarisstructurur belangrijk is willen openbare diensten tegen een redelijke prijs tot stand kunnen komen.

\footnotetext{
61 Zie vow een nadere uitleg over het instituut kriggsmacht Charles C. Moskos, Jit, "From Insititution to Occupation: Trends in Military Organization," Armed Forces and Society, vol. 4 (fall 1977), p. 42.

62 United Kingdiom, National board for prices and incomes, Standing reference on tha pay of the armed forces: second report, Report 116, blz. 6 in: Binkin en Kyriakopoulos, Paying the modern military, blz. 21.

63 Bürikin and Kyriakopoulos, op cit., blz $21-22$.
} 
In de burgermaatschappij bestaan er grote verschillen in beloning tussen verschillende beroepen. Verschillen dile ontstaan door de aard van het beroep, functiezwaarte, de menselijke investering welke voor het beroep verricht is, de alternatieve arbeidsmogelijkheden (schaarste) en het groeipotentieel dat a an iedere functie verbonden is.

In de krijgsmacht is hier weinig van terug te vinden. Sterker nog, het militaire beloningssysteem kenmerkt zich juist door de afwezigheid van beroepsmatige verschillen, en dat terwijl er toch een grote hoeveelheid taken in de krijgsmacht te verrichten is. Zoals we hiervoor reeds gezien hebben is deze afwezigheid van beroepsmatige verschillen in beloning niet geheel onverwacht, omdat het de natuurlijke uitkomst is van een beloningssysteem dat alle taken als even belangrijk ziet en daarom als even produktief. Maar zo'n systeem is slechts te handhaven in een wereld waar schaarste afwezig is, of in een wereld waar er voldoende mensen zijn die genoegen nemen met fenomenen als groepsvoldoening en psychologisch inkomen. Helaas zijn er maar weinig landen in de wereld waar mensen genoegen nemen met fenomenen als psychologisch inkomen, zodat het beloningssysteem van de krijgsmacht alleen stand kan houden, indien de arbeidsplaatsen voor een groot deel worden opgevuld met behulp van dienstplichtigen.

Afschaffing van die dienstplicht roept schaarste op en daarmee ook een beloningssysteem dat geschikt is om het schaarsteprobleem te beteugelen. Door het huidige beloningssysteem en het streven naar uniformiteit is de krijgsmacht niet in staat in te zien dat sommige taken als minder attractief, moeilijker, beter of slechter dan andere taken worden gezilen. Ook wordt door het beloningssysteem niet voldaan aan de elementaire wetten van vraag en aanbod op de arbeidsmarkt, waardoor het vullingsprobleem in een vrijwilligersleger alleen nog maar groter wordt.

Afschaffing van de dienstplicht vraagt om een beloningssysteem dat voldoet aan de wetten van de markt en dat in overeenstemming is met de gebruikelijke beloningssystemen in de burgermaatschappij. Dit betekent dat het beloningssysteem in overeenstemming moet zijn met de zwaarte van de functie, het opgebouwde human capital, de aard van de functie, schaarstefactoren en groeimogelijkheden. Dit betekent tevens dat de krijgsmacht zich in haar beloningssysteem dient te ontdoen van de karakteristieken die haar zo anders maken dan de burgermaatschappij. De overgang van een dienstplichtigenleger naar een vrijwilligersleger betekent de overgang van een confectiepak naar een maatpak. Een maatpak dat ook voor de beloning noodzakelijk is. In zo'n maatpak is er geen plaats meer voor algemene salarisverhogingen, maar zal er veel meer gedacht moeten worden aan bonussen en schaarste premies, extra periodieken en prestatiebeloning:

\footnotetext{
"Expanded use of bontises is certain to taise the basic issue of whether the military institution is willing to concede that one skill deserves higher compensation than another at the same rank and grade levels and, more broadly, whether the reform of military pay policy should be reduced to provision af unequal pay for the same grade." 64
}

Met alle mogelijke arbeidsmarktinstrumenten zal ervoor gezorgd moeten worden dat de voorziening van het collectieve goed clefensie gehandhaafd blijft, terwijl de financiële gevolgen binnen de perken blijven.

Eerder in deze paragraaf is reeds ter sprake gekomen dat er door het gesloten personeelssysteem van de krijgsmacht en de opwaartse stroming door de organisatie een automatisch instrument in de krijgsmacht bestaat dat er voor zorgt dat ervaren

64 Binkin en Kyriakopoulos; op cit, blz. 44. 
mensen de organisatie dienen te verlaten, omdat er hogerop in de organisatie geen plaats meer voor ze is. Het aantal rangen is gewoonweg op.

Ook is er binnen de krijgsmacht geen plats om te voldoen aan salariseisen van ervaren personeel, omdat een hoger salaris automatisch een hogere rang vereist, terwijl er hiërarchisch gezien geen plaats meer is voor deze mensen. Het gevolg is dat deze mensen de organisatie zullen verlaten, en de krijgsmacht op zoek moet naar nieuwe mensen die pas over langere tijd dezelfde ervaring zullen hebben als de man die net is weggegaan.

De second-best oplossing waartoe de krijgsmacht gedwongen is in haar personeelsbeleid heeft met name haar oorzaak in de strikte koppeling van rang aan salaris* schaal. De rang is een persoonlijke titel van een individu in de krijgsmacht. De krijgsmacht kent rangen van soldaat tot generaal met daartussen een groot aantal andere rangen. ${ }^{65}$ Dat de krijgsmacht zoveel rangen kent, komt omdat zij zich richt op het institutionele karakter van het millitaire apparaat en niet op de beroepsmatige kant. In een institutioneel bestel is de aandacht niet gericht op functies of taken, maar op personen en daarom ook op de persoonlijke titel van deze personen, de rang. Het onderscheid in titels wordt vervolgens expliciet gemaakt door een hiërarchisch systeem, waarin een duidelijke volgorde in titels naar voren komt.

Een salarisschaal is een stap of een graad in een waarderingsschaal, welke aan een functie gekoppeld is. De salarisschaal geeft gewoonweg weer hoeveel geld iemand krijgt voor een arbeidsprestatie. Aangezien rang en salarisschaal op een direkte manier gekoppeld zijn, geeft in de krijgsmacht niet de salarisschaal weer wat iemand verdient, maar doet de specifieke rang dit. Wil de krijgsmacht iemand beter belonen dan moet hij of zij in rang omhoog, omdat een nadere onderverdeling van de salarisschaal simpelweg ontbreekt.

Hoewel er in de oorspronkelijke vorm van het militaire beloningssysteem geen plaats is voor functiespecifieke waardering, is ook de Nederlandse krijgsmacht er niet aan ontsnapt toch enige elementen van een functiespecifieke waardering over te nemen. De oorzaak van dit feit heeft te maken met een ontwikkeling in de technologie die een behoefte aan hoger geschoold personeel noodzakelijk maakt. Personeel wordt voor de extra scholing en taken beloond met een hogere rang, waardoor voor buitenstaanders de indruk bestaat dat er een soort ranginflatie binnen de krijgsmacht ontstaat.

In 1991 is door het bureau Zuidema een onderzoek verricht naar ranginflatie binnen de krijgsmacht. Uit haar rapport "Is rang alleen rang als er rang op staat?" komt naar voren dat het onweerlegbaar aantonen van het al dan niet besta an van ranginflatie niet mogelijk is gebleken. Wel wordt een kwantitatieve toename van functies met een hogere rang ("opwaartse druk") geconstateerd. Dit verschijnsel blijkt zich echter eveneens, en in sterkere mate, bij de burgerlijke tijksoverheid voor te doen. Hiermee wordt een ontwikkeling weerspiegeld, die verwijst naar de doorwerking van de toenemende complexiteit van maatschappij en technologie in bestuurlijke functies. 66

Het niet kunnen aantonen van ranginflatie is niet verrassend indien we de doot bureau Zuidema ontwikkelde definitie van ranginflatie mader beschouwen. Deze, zeet juiste, definitie luidt:

65 De rangen zajin als volgt: 1) soldaat, 2) soldaat der eerste klasse, 3) korporaal, 4) korporanal der cerste (klasse, 5) sergeant, 6) sergeant der eerste klasse, 7) sergeant-majoor, B) adjudant/vaandirg, 9), tweede luitenant, 10) ow rste Jwitenant, 11) kapittein, 12) majoor, 13) luitenant-kolonel (overste), 14) kolonel, 15) brigade-generaal, 16) generaalmajoor, 17) luitenant-genteraal en 18) generaal.

66 N, van Dijkhuizen en P.H.J. Suiker, Is rang alleen rang alls er rang op staat?, Lewsdien, 1991. 
"Ranginflatie is een asymetrische ontwikkeling van de hoogte van de rang en de zwaarte van de functie, waarin de hoogte van de rang de functiezwaarte in ontwikkeling overtreft".

Uit deze definitie blijkt dat er een verband dient te zijn tussen rang en functie wil er sprake zijn van ranginflatie, terwijl we hiervoor hadden gezien dat de krijgsmacht juist niet de nadruk legde op een verband tussen rang en functie, maar tussen rang en personen. Een verband dat voortkomt uit het institutionele karakter van de krijgsmacht. Een onderzoek naar ranginflatie is dan ook bij voorbaat gedoemd tot een mislukking. Wel geeft het bureau Zuidema in zijn rapport enige aanbevelingen om de opwaartse druk op de rangen te beheersen. Naast de aanbeveling om een goed registratiesysteem op te zetten en een bedrijfsmatig standaardmodel voor de opbouw van de organisatie te ontwikkelen, komt het bureau Zuidema tot een derde mogelijkheid, die voornoemde mogelijkheden in het niet doet vallen, doordat zij in wezen een stabielere organisatievorm mogelijk maakt dan het voorgaande. Bureau Zuidema adviseert:

"In dit wooronderzoek stuitten wij herhaalde malen op het verschijnsel dat (bijwoorbeeld) doordat de technologie ingewikkelder werd men beter opgeleide mensen voor bepaalde taken behoefde die beter betaald moesten worden (marktwaarde) en derhalve een hogere rang kregen aangemeten. Het lijkt zinvol deze oneigenlijke trits te doorbreken door:

- als boven genoemde organisatiemodellen te kiezen met vaststaande rangen (voorzover men, bijvoorbeeld met het oog op de oorlogsorganisatie, hiërarchie nodïg heeft, danwel in vergelijk met buitenlandse krijgsmachten bepaalde rangen nodig heeft in verband met samenwerkingsprojecten en elders heersende culturen);

- bezoldiging los te koppelen van (in feite) de dienstjaren en dus de rangen, en vervolgens te koppelen aan de (objectlef vast te stellen) functiezwaarte, met de daaraan verbonden vorm van prestatiebeoordeling.

Op deze wijze kan men flexibel reageren op wijzigingen in de organisatie of op een onvoorziene externe bemanningswraag, terwijl men, zonder de vooraf gekozen structuur van de krijgsmacht aan te hoewer tasten darwel te moeten zoeken naar een aantal oneigenlijke aanpassingen var het beloningssysteem, beter kan inspelen op de situatie op de arbeidsmarkt." 67

Bureau Zuidema slaat hiermee de spijker op zijn kop. Om het beloningssysteem aan te passen aan de behoeften van een vrijwilligersleger dient het salaris losgekoppeld te worden van de rangen. Het salaris dient gekoppeld te zijn aan de zwaarte van de functie, inclusief alle elementen die in de salarisopbouw van een functie in de burgermaatschappij ook aanwezig zijn.

Rangen zijn voorbestemd om als coördinatiemechanisme te fungeren, en de ontwikkeling van salarisschalen binnen de krijgsmacht moet voorzien in de behoefte militairen te kunnen belonen naar functiezwaarte en niets anders. Als een bedrijf twee maal zo groot wordt, dan krijgt de directeur een hoger salaris, maar hij blijft directeur en wordt geen directeur der eerste klasse! In de krijgsmacht dient er eigenlijk geen verschil te zijn met een bedrijf.

De krijgsmacht zelf was zich reeds enige tijd bewust van het verschijnsel dat haar personeelssysteem niet goed functioneerde. Toch duurde het tot 1 januari 1990 voordat an het element "functiezwaarte" een groter gewicht werd toegekend. Als gevolg daarvan is de rang gekoppeld aan de functie en is daarmee sprake van een indirecte koppeling van bezoldiging aan functie. De aanbeveling van het bureau Zuidema om

67Van Dijkhuizen en Sulker, op cit. blz. 60. Zie voor dezelfde bewoordingen Binkin en Kyriakopoulos, Paying the Modern Military, hoofdstuk 4. 
de bezoldigingssystematiek structureel te veranderen vindt de Minister van Defensie Ter Beek een te zware ingreep. ${ }^{68}$ Daarmee geeft hij impliciet toe dat hij de koppeling tussen rangen en salaris in stand houdt en hij het schaarstebegrip onvoldoende in de vingers heeft.

In paragraaf 6.2 hebben we kunnen zien dat de taken van de Nederlandse krijgsmacht in de toekomst verder uitgebreid worden. Taken die qua inhoud, risico en opleiding aanzienlijk kunnen verschillen. Daar er een grote differentiatie in taken zal zijn heeft de krijgsmacht ook personeel van een divers pluimage nodig. Werving van personeel dient afgestemd te zijn op de wensen qua opleiding, risicoprofiel en contractduur van de toekomstige militair. De "matching" van taken en wensen kan dan alleen een goed resultaat hebben, indien deze vergezeld wordt van een differentiatie in beloning. Deze differentiatie is praktisch slechts uitvoerbaar indien de banden tussen rangen en salarissen worden losgesneden en wordt overgegaan naar een flexibel beloningssysteem.

Daamaast dient de top-down benadering in de krijgsmacht vervangen te worden door een meer bottom-up benadering van het personeelsbeleid. Door invoering van het subsidiariteitsbeginsel in de krijgsmacht krijgen we een situatie dat militairen alleen een hogere rang hebben, indien dit voor de coördlinatie tussen verschillende onderdelen in de krijgsmacht noodzakelijk is. Functies die puur met toezicht te maken hebben, worden op deze manier uitgeschakeld omdat het beroepspersoneel zelf wel in staat is haar taken naar behoren uit te voeren. Subsidiariteit houdt in dat bij een optimale besluitvorming alleen die besluiten die niet op een lager, meer gedecentraliseerd niveau kunnen worden afgedaan op een hoger niveau worden genomen. Dit bespaart in de eerste plaats een groot aantal schaarse mensen, maar betekent ook dat in een oorlogssituatie de effectiviteit verbetert, omdat er minder kans is dat een eenheid uit elkaar valt door gevechtshandelingen. Des te groter de groep, des te groter de kans op desintegratie. Een ander nevenverschijnsel van het subsidiariteitsbeginsel binnen de krijgsmacht is dat de inhoud van de functie met de laagste rang sterk in waarde toeneemt, waardoor deze functie een heel stuk interessanter wordt.

De Nederlandse krijgsmacht zal zich in de toekomst een maatpak voor haar uit te voeren taken moeten laten aanpassen. Zonder een nader oog voor de details lukt dat echter nooit. De organisatie moet op ieder onderdeel aan dit maatpak voldoen en dus ook op het gebied van de beloning. Het huidige beloningssysteem is niet alleen hard a an vervanging toe, het nodigt juist uit tot een drastische verbouwing. Allereerst is het noodzakelijk dat militaire managers rang en salaris strikt gescheiden houden. Het belonings- en waarderingssysteem dient vervolgens zo te worden opgezet, dat er nog steeds gelijke mogelijkheden voor promotie zijn (de soldaat van vandaag moet nog steeds de sergeant van de toekomst kunnen worden), maar de salarisschalen moeten kunnen variëren onafhankelijk van de rangen. De salarisschalen dienen het meest uiltgebreid te zijn bij die categorie functies waar de trainingskosten het hoogst zijn (F-16vliegers), en waar lange contracten het meest wenselijk zijn. Niet verbazingwekkend zijn dit ook de functies waar de "retention-rate" het meest onder druk staat. Juist een groter aantal schalen bij een functie zal er in kunnen voorzien dat er financiële prikkels zullen bestaan om iemand zo lang mogelijk in dienst te houden.

De mate waarin de twee belangrijkste personeelsbeleidsinstrumenten - promotie en beloning - naast elkaar gebruikt kunnen worden, zal een indicator zijn voor effectief personeelsbeleid. Het loskoppelen van rangen en salaris zal niet alleen een effi-

\footnotetext{
68 Brief $90 / 377 / 23459$ aan de Voorzitter wan de Tweede Kamer der Staten Generaal, 'G-Giravenhage, 14 november
} 1991. 
ciêntieverbetering opleveren, het zal ook bijdragen aan de kwaliteit van de krijgsmacht waardoor een lagere behoefte aan persioneel ontstaat. Door de lagere behoefte aan direkt-produktief personeel ontstaat vervolgens een multipliereffect ten aanzien van de behoefte aan niet-direkt-produktief personeel, zodat de totale personeelsaantallen in de pijplijn flink zullen verminderen. De mogelijkheden om de "retentionrate" en de kwaliteit van de krijgsmacht te verbeteren via een verandering van het beloningssysteem zijn zeer belovend, maar kunnen pas echt een succes worden indien ook het pensioneringsbeleid herzien wordt.

Het huidige pensioneringsbeleid heeft als woomaamste reden dat de krijgsmacht een jeugdige krijgsmacht dient te zijn. In de Koninklijke Marine gaan mensen op hun 50 e met pensioen en voor de overige krijgsmachtdelen geldt een leeftijdsontslag van 55. Het verschil tussen de Koninklijke Marine en de overige krijgsmachtdelen wordt veroorzakt door de compensatie die marinemensen krijgen voor de tijd dat zij geen voet aan vaste wal hebben kunnen zetten tijdens hun diensttijd. In een personeelsbeleid dat zich richt op ervaring is de uittreding op 50 of 55-jarige leeftijd een vreemde cend in de bijt. Een herziening van het pensioneringsbeleid dient daarom gericht te zijn op het in stand houden van een meer ervaren krijgsmacht en moet samengaan met een harmonisatie in beloningstructuren, om er voor te zorgen dat ervaren mensen op de toppen van hun kunnen de krijgsmacht niet vervroegd verllaten.

De reden van het "functionele leeftijdsontslag" is altijd gelegen geweest in het kunnen voldoen aan de fysieke vereisten van de krijgsmacht. Daarmaast is het huidige pensioneringsbeleid bedoeld als een aantrekkelijk deel van de beloning van de militair en dient zij als een vergoeding voor de speciale institutionele karakteristieken van het leven als militair. Tenslotte dient het pensioen de overgang naar het burgerleven te vergemakkelijken.

Aan de nadruk op een jeugdige krijgsmacht is in het begin van de paragraaf reeds uitvoerig aandacht besteed. Een jeugdige krijgsmacht is een misvatting en dat geldt nog meer in een vrijwilligersleger dan in een dienstplichtigenleger. Zelfs al zou het waar zijn dat een jeugdige krijgsmacht noodzakelij $k$ is voor het in stand houden van de gevechtskracht, dan nog is het twijfelachtig of vervroegde pensionering daar nu echt aan bijdraagt. Vrijwell alle militairen die voor vervroegde pensionering in aanmerking komen, zijn niet afkomstig uit de gevechtsonderdelen. Het is zelfs zo dat een aanzienlijk deel van deze militairen nooit een gevechtsfunctie gezien heeft. Ook aan de produktiviteit en kwaliteit van de uittredende militairen hoeft niet getwijfeld te worden. Een groot deel van de gepensioneerde militairen gaat na vertrek bij de krijgsmacht gewoon verder met diverse functies in de burgermaatschappij.

Het huidige pensioneringssysteem heeft verder als nadeel dat het de beloning van een functie in de krijgsmacht niet echt zichtbaar maakt. Hoewel de krijgsmacht wil dat de militair zijn baan als een roeping ziet, ligt dat voor de meeste militairen toch anders: Zeker bij jonge militairen speelt het vooruitzicht op een goed pensioen weinig tot geen rol bij de keuze toe te treden tot de krijgsmacht, omdat dit toekomstig inkomen zover weg is dat de waarde van dit inkomen een relatief laag gewicht krijgt. In vergelijking met functies in de burgermatschappij betekent dit vervolgens dat het animo voor een baan in de krijgsmacht achter blijft. Het huidige pensioenbeleid dient daarom gewijzigd te worden en de beste manier om dit te doen is door het huidige systeem te laten aansluiten bij het pensioensysteem dat burgerambtenaren kennen.

De krijgsmacht zal zich moeten aanpassen aan de normen en waarden van de burgermaatschappij wil zij op een meer efficiënte wijze omgaan met de schaarse hulpmiddelen in de maatschappij. Het vasthouden aan eigen normen en waarden, vaak stammend uit de Napoleontische tijd, kan betekenen dat de krijgsmacht altijd 
een second-best beleid zal moeten blijven voeren. Dit second-best beleid kan zij zich. nog wel veroorloven in een dienstplichtigenleger, omdat daar de vulling van het personeel gegarandeerd is. In een vrijwilligersleger betekent het vasthouden aan de eigen normen en waarden het ingooven van de eigen glazen. In een vrijwilligersleger dient niet het instituut krijgsmacht voorop te staan, maar het beroep militair. Een beroep net als ieder ander beroep in de maatschappij.

\section{$\S 6.5$. Slotopmerkingen}

In dit hoofdstuk hebben we gekeken naar de arbeidsmarkt voor militairen. Uit dit hoofdstuk blijkt dat de vergelijking van de krijgsmacht met de burgermaatschappij in een vrijwilligersleger een belangrijke rol speelt. In tegenstelling tot in een dienstplichtigenleger dient de krijgsmacht nu te concurreren met de overige sectoren in de maatschappij om de schaarse arbeidskrachten.

In dit concurrentieproces speelt de vergelijking van beloningen, zowel materieel als immaterieel, een belangrijke rol. In tegenstelling tot in een dienstplichtigenleger beperkt dit zich niet tot een interne vergelijking in de krijgsmacht, maar dient de vergelijking zich uit te breiden tot de gehele maatschappij. Dit betekent dat verschillen in beloning verbonden dienen te zijn aan verschillen in zwaarte van de functie, verschillen in vaardigheden en het aanbod op de arbeidsmarkt. In plaats van een macrobenadering van het personeelsbeleid dient het personeelsbeleid zich te concentreren op de bezetting van de specifieke functies in de krijgsmacht. Het confectiepak dient plaats te maken voor het maatpak. Een maatpak waarin geen plaats meer is om een vrijwilliger te behandelen alsof hij bezit is van de generaal, maar een maatpak waar rekening gehouden dient te worden met de wensen van iedere afzonderlijke vrijwilliger. De krijgsmacht is een groot bedrijf met honderden functies, zodat het niet echt moeilijk zal zijn om te voldoen aan de wensen van de individuele vrijwilliger. Mocht deze vrijwilliger eventueel toch niet voldoen aan de wensen van de krijgsmacht en er zijn geen alternatieven voorhanden, dan dient de krijgsmacht niet te schromen zelf de middelen ter hand te nemen om haar" wensen te laten "matchen" met de wensen van de vrijwilliger. Een vrijwilligersleger vraagt om een humaan en reëel personeelsbeleid. Niet alleen maar omdat dit de vrijwilligers goed uit zou kunnen komen, of omdat het de maatschappij zowel in menselijk als in financiëel oogpunt ten goede komt, maar vooral omdat het een uitkomst voor de krijgsmacht zelf is, omdat zij daardoor de vullingsproblemen waarvoor zij in een vrijwilligersleger gesteld wordt op een gemakkelijke wijze kan oplossen. 


\section{De wisselwerking tussen maatschappij en krijgsmacht}

"Een (....) misverstand is dat privatisering geen betrekking kan hebben op de zogenaamde echte collectieve goederen".

P.B. Boorsma in: Openbare Uitgaven 16, oktober 1984, blz. 299.

De krijgsmacht maakt deel uit van onze maatschappij. Wij weten niet anders dan dat er een krijgsmacht is in onze samenleving. Doch, wil er een krijgsmacht bestaan dan is het noodzakelijk dat deze wordt aanvaard door de maatschappij. Indien de maatschappij cle noodzaak van een krijgsmacht niet inziet, dan kan de krijgsmacht beter ophouden te bestaan. Naast de maatschappelijke aanvaarding in algemene zin om te kunnen bestaan, heeft de krijgsmacht tevens een bepaald niveau van maatschappelijke aanvaarding in specifieke zin nodig om goed te kunnen functioneren:

"Mensen moeten er willen werken niet alleen in verband met de maatschappelijk aarvaarde doelstellingen van de organisatie, maar ook in verband met de rechtspositie, de aard van de werkzaamheden en de omstandigheden waaronder deze moeten worden verricht". ${ }^{1}$

Het begrip "maatschappelijke aanvaarding" wordt door het Ministerie van Defensie nog niet zo lang als beleidsbegrip gehanteerd. Tot in de jaren vijftig bestond het Defensiebeleid slechts uit twee centrale onderwerpen: ${ }^{2}$

- de doeltreffendheid van de organisatie

- de doelmatigheid van de organisatie.

Het personeel stond volledig ten dienste van de organisatie, 24 uur per dag. Personeelsbeleid betekende voor het overgrote deel niet meer dan personeelsbeheer. De mens in de krijgsmacht werd vrijwel alleen gezien in zijn militaire rol en werd geacht daarin als persoon volledig op te gaan. Het militaire apparaat was in de jaren vijftig nog zeer gesloten.

Deze geslotenheid van de krijgsmacht heeft altijd de vrees met zich mee gebracht dat de krijgsmacht zich zou ontwikkelen tot een "staat in een staat". De gedachte van de "staat in de staat" is al heel oud en wordt onder meer genoemd door Niccolo

\footnotetext{
${ }_{1}$ MRK-advies nx. 14, Maatschappelijke aanvaarding van da krijgsmacht, Den Haag 1988, biz. 5 . en Maatschappelijke Raad voor de Krijgsmacht, Evaiuatie maatschappelijke aanvaarding wan de krijgsmacht 19881991, advies 14/1, Den Haag, 1991.

${ }^{2}$ Idem, blz, 3 .
} 
Machiavelli (1469-1527) in zijn "Dell arte delle guerra" ${ }^{3}$ Machiavelli pleitte ter voorkoming van een "staat in de staat" voor de mogelijkheid van de militaire dienstplicht. Hij deed dit omdat hij in de militaire dienstplicht een obstakel zag voor iedereen die de macht wilde grijpert. Volgens hem was een leger dat een doorsnee van de samenlleving was betrouwbaarder dan een vrijwiligersleger.

Machiavelli's pleidooi om de wisselwerking tussen maatschappij en krijgsmacht te bevorderen door de militaire dienstplicht wordt ook door anderen gevolgd. Het Ministerie van Defensie komt in de Defensienota 1968 met de volgende verklaring over de dienstplicht:

"De Koninklijke Landmacht heeft door haar grote verspreiding en doordat zij zoveel dienstplichtigen omvat, veel meer directe contacten met de Nederlandse samenleving dan beide andere krijgsmachtdelen. Daardoor worden haar gewoonten, haar werkwijze en de bij haar bestaande verhoudingen welhaast voortdurend getoetst aan wat elders in de Nederlandse samenleving als normaal en juist geldt. Mede om deze reden moet de landmacht zich doorlopend bezinnen op de juistheid en de gerechtigheid van haar gewoonten, werkwijze en verhoudingen. Dit geschiedt in steeds toenemender mate" 4

Voor het eerst noemt een Defensienota de maatschappelijke effecten van de millitaire dienstplicht naast het vullingsargument. Veel directer zijn deze woorden terug te vinden in de Defensienota 1984 :

"De dienstplicht is niet alleen een onmisbaar instrument voor de vulling van de krijgsmacht, ze bevordert ook de wisselwerking tussen krijgsmacht en samenleving " 5

Terwijl in de Defensienota 1984 nog eerst de vulling wordt genoemd en daarna pas de matschappelijke effecten draait de Defensienota 1991 de volgorde juist om. Over de mogelijkheid van een vrijwilligersleger zegt de nota:

"Een krijgsmacht met dienstplichtigen verzekert echter de betrokkenheid van de samenleving bij haar verdediging. Ook leidt een permanente doorstroming van jonge Nederlanders tot een grotere ontvankelijkheid van de krijgsmacht voor maatschappelijke ontwikkelingen. Daardoor is het eenvoudiger te verzekeren dat de krijgsmacht een afspiegeling blifft van de samenleving waarvan zij deel uitmaakt. Een meer praktisch aspect dat moet worden bezien is de mogelijkheid woldoende vrijwilligers te werven".6

De vraag hierbij is echter wel of dit een praktische ontwikkeling of een politieke beleidskeuze betreft. In 1991 was er sprake van een eventuele afschaffing van de dienstplicht. Het moet daarom niet uitgesloten worden geacht dat in de Defensienota 1991 getracht is de dienstplicht te behouden op basis van het argument van de wisselwerking tussen matschappij en krijgsmacht, daar reeds bekend was dat het vullingsargument voor de instandhouding van de dienstplicht niet langer houdbaar was. Directe aanwijzingen voor de houdbaarheid van deze stelling zijn echter niet aanwezig.

In het algemeen kan de wisselwerking tussen maatschappij en krijgsmacht zo worden omschreven dat de normen en waarden in de krijgsmacht een afspiegeling zijn van de normen en waarden in de maatschappij. Daarnaast zal de maatschappij een politieke controle moeten uitoefenen over de krijgsmacht op een zodanige wijze

\footnotetext{
3Zir o.a. M.L. Tiesinga, Dienstplicht: van millitaire naar sociale? , proefversie Armex Defonsie Magazine (1992).

4 Zie VVDM-rapport "Eindo owefening", Utrecht 1992, blz.6.

5 Viden.

6 Defensienota 1991, Ministerie van Defensie, Den Haag 1991, blz. 176.
} 
dat de krijgsmacht zich niet kan ontwrikkelen tot een "staat in een staat" en de regering de baas is over de krijgsmacht.

Uit deze omschrijving kunnen de volgende vragen worden afgeleid. Welke elementen in de krijgsmacht kunnen er voor zorgen dat de normen en waarden in de krijgsmacht afwijken van wat in de maatschappij normaal is en wel op een zodanige wijze dat deze ook een bedreiging voor de rest van de maatschappij vormen? Daar aan gekoppeld is de vraag welke instrumenten de afsplegeling van de maa tschappelijke waarden en normen in de krijgsmacht en de politieke controle op de krijgsmacht kunnen overnemen indien de dienstplicht niet meer gebruikt kan worden als instrument?

\section{\$7.1. Het korps officieren}

De krijgsmacht kent een overwegend gesloten personeelssysteem en zoals we reeds eerder gezien hebben daardoor een opvallende personeelsstructuur en -culturur. De cultuur in de krijgsmacht is nauw verbonden met een sterke discipline die hiërar. chisch georganiseerd is. Deze cultuur kan er toe leiden, dat mensen gedwongen worden handelingen te verrichten die hun eigenlijk vreemd zijn, en in kunnen druisen tegen de principes van de samenleving, maar die zij moeten doen omdat ze in een ondergeschikte situatie verkeren. Meer dan eens zijn soldaten gebruikt om staatsgrepen te plegen.

De internationale geschiedenis laat zien dat het daarbij niet zoveel uitmaakt of deze ondergeschikten nu beroepsmilitairen of dienstplichtigen zijn. Zo zijn er vele staatsgrepen, zoals die in Chili 1973, met behulp van dienstplichtigen gepleegd. Canby schrijft over de empirische toetsing van dit fenomeen:

"The assertion that a high-turnover, socially representative military is less dangerous to democratic in" stitutions than a volunteer force is not empirically supportable. Although the refusal of conscripts to obey their immediate superiors was a key factor in the collapse of the French Army Coup against the Gaulle in 1960, other eclectic examples Indicalte that conscription is not a sufficient condition to insure against coups. Greece has universal conscription and Brasil and Peru have selective conscription. Not only is conscription no insurance against coups, the conscription/voluntarism issue is only loosely related to political threats from the military as an institution. This is because the military threats to any existing political order generally come from the officer corps, which control the millitary and is the most direct position to influence political institutions ${ }^{19}$ : 7

Willen we controle kunnen uitoefenen op het democratisch gehalte van de krijgs macht dan is het zaak de top van de hierrarchie te controleren. En hierbij is een onderscheid tussen een dienstplichtigenleger en een vrijwilligersleger niet nodig, omdat de uitwoering van een doelmatige en effectieve krijgsmacht altijd een professioneel korps officieren vereist. Dit verandert niet indien het recruteringssysteem in de krijgsmacht verandert. De kerngroep, welke een potentiële dreiging voor de maatschappij kan vormen, zal altijd dezelfde mensen bevatten onder welk recruteringssysteem dan ook. Beweringen dat een krijgsmacht met een groot personeelsverloop essentieel is voor een verburgerlijkte krijgsmacht kunnen door de empirie niet bevestigd worden. Dit wordt nog duidelijker als we beseffen dat jonge dienstplichtigen relatief weinig contact hebben met oudere officieren. Wil het korps officieren daadwerkelijk beinvloed

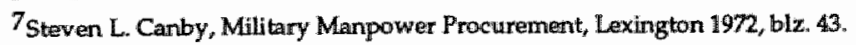


worden dan is het noodzakelijk dat de officieren er persoonlijk iets van merken, waardoor hun gedrag of hun gedachten veranderen.

Uitgangspunt bij de beirnvloeding van het korps officieren is dat deze beinvloeding zich dient te richten op een politieke neutralisatie van het korps officieren zonder dat getornd wordt aan de primaire taken van de officieren. Theoretisch zijn er een aantal manieren on de militaire top te neutraliseren. De eerste methode gaat uit van indoctrinatie van het korps officieren, om er voor te zorgen dat de militaire leiders de standpunten delen van de leidende groep politici in de maatschappij. Deze methode is grootschalig toegepast door de voormalige communistische totalitaire regimes. Ook in Nederland komt het vragen van loyaliteit van hoge officieren jegens de politiek wel eens voor. ${ }^{8}$

Een tweede methode is het opleggen van formele politieke controle. Vaak wordt deze formele politieke controle ook nog eens ondersteund door een grote mate van informele politieke controle. Bij de formele en informele politieke controle kan gedacht worden aan inspectieorganen, milieugroepen, anti-militaristische groeperingen, omwonenden van kazernes en oefenterreinen enz. Ook vallen hier de arbeidsinspectie, de Algemene Rekenkamer en de ombudsman onder.

Een derde methode is de versplintering van het korps officieren in diverse sociologisch-politieke groeperingen. Het doel van de versplintering is te komen tot het doorbreken van de eensgezindheid onder officieren over bepaalde orders die kunnen leiden tot ondemocratische acties. Een sociaal-politiek gemengd korps officieren zal het veel moeilijker hebben om samen te smelten met én bepaalde groep burgers en theeft tot gevolg dat het korps officieren zich zal splitsen, indien éen bepaalde groep burgers om de steun van de officieren vraagt.

Om tot een gediversificeerd korps officieren te komen zijn een aantal mogelijkheden voorhanden. Allereerst kan verregaande arbeidsverdeling binnen de krijgsmacht leiden tot diversificatie van taken en de mogelijkheid tot het aantrekken van een groter potentieel aan mogelijke officieren, omdat er meerdere taken te volbrengen zijn in de krijgsmacht. Of zoals Canby zegt:

"If the services would allocate their best talent by special assignments instead of dispersing them through standardized career patterns, the military would be more attractive to high opportunity-cost talent and fewer would be needed".9

Een andere diversificeringstechniek sluit aan bij de opleiding van officieren, en heeft als doel het curriculum van militaire opleidingsinstituten te verbreden. In de praktijk komt dit neer op de ansluiting en samenwerking van militaire academies bij reguliere universiteiten en hogescholen, waardoor de strikte band met de krijgsmacht losser wordt gemaakt.

Een vierde methode heeft tot doel de grip van het oudere en hiërarchisch hogere personeel op de jongeren te verzwakken. Evenals de vorige methode zijn dit manieren om de krijgsmacht van binnen uit aan te laten sluiten bij de normen en waarden

\footnotetext{
8 Dit is onderneer in 1992 voorgekomen. Een genteral van de Koninklijke Landmacht, luitenant-generaal Couzy, uitte zijo bezorgdheid over de herstructurering van de krijgsmacht to een opiniestuk in NRC-Handelsblad. In een reactio w as een deel van de politiek van mening dat een generaal zijn mening voor zich moest houden. Volgens de politicl is het an hen voorbehouden politiek te bedrijwen, generaals moesten ztich bezighouden met het commanderen wan hun troepen. Naar aanleiding van deze gebeurtenis werd generaal Couzy gedwongen een loyaliteitsverklaring to takenen, wat hem or overigens niet van weerhield te stoppen met het geven van zijn mening ower krijgsmachtspeciffeke taken in hat openbaar. Zie onder andere zija tnterview met het VVDM-maandblad "20", april 1993

9 Canby, op cit. blz: 244.
} 
van de burgermaatschappij. De eerste twee methoden zijn voornamelijk controlemiddelen van buiten af opgelegd. Volgens Canby kan bij het verzwakken van de grip op de jongere soldaten vooral gedacht worden aan het onderbreken en beïnvloeden van de tussenliggende schakels, de intermediaire rangen:

"This means that the onus of blocking anti-state acts of senior officers is on career officers in the inter" mediate ranks. Given the vise-like control seniors have over their subordinates' career ${ }^{\prime}$ these intermediate officers are in a difficult position. Any questioning of the legality of an order, correct or not, may well ruin their subsequent millitary careers unless institutional protection is provided by a grateful government." 10

De afhankelijkheid van de jongere officier van de oude officier kan op een aantal manieren verzwakt worden. Zo zal het stellen van hoge toelatingseisen tot het korps officieren hopelijk leiden tot een hogere kwaliteit officieren, die moreel en economisch onafhankelijk zijn door hun hogere intelligentie, grotere politieke bewustzijn en betere civiele mogelijkheden. Bovendien is het aanbevelenswaardig er voor te zorgen dat de officieren die de communicatie en beslissingen verzorgen, de officieren zijn met de beste opleidingen en het hoogste potentieel.

De belangrijkste schakel is echter het promotiesysteem. Het promotiesysteem in de krijgsmacht zou zo in elkaar moeten zitten dat lagere officieren zo min mogelijk afhankelijk zijn van de goodwill van hun directe meerderen. Een promotiesysteem waarin een balans is tussen prestatie, wat niet objectief gewaardeerd kan worden $x_{x}$ en intelligentie, wat well objectief te bepalen is, kan de afhankelijkheid verminderen. In zo'n systeem ligt de nadruk op de functievereisten om een bepaalde rang te kunnen vervullen en niet op de lengte van de diensttijd of de loyaliteit ten opzichte van de meerdere. Daarbij draagt het tevens bij aan een vermindering van zwakke elementen die in het management van diverse krijgsmachtdelen gesignaleerd wordt. Het management in de krijgsmacht theeft namelijk de neiging te veel nadruk te leggen op persoonlijke leiderschapskwaliteiten en de cognitieve elementen voor het goed kunnen uitvoeren van dit leiderschap te veronachtzamen of zelfs te negeren. Overigens is binnen het Ministerie van Defensie sinds het begin van de jaren negentig de nadruk al steeds meer verschoven in de richting van functievereisten en cognitieve elementen.

Hiervoor is voornamelijk gekeken naar het middenkader. De invloed die soldaten op hun meerderen kunnen uitoefenen moet echter niet vergeten worden. Vooral in Nederland hebben de soldaten een baanbrekende rol gespeeld bij het verminderen van de grip van de officieren op de soldaten.

Soldaten hebben ieder voor zich weinig te vertellen. Zij hebben bevelen op te volgen en daarmee klaar. Weigering van een dienstbevel kan immers leiden tot strafvervolging. De Nederlandse geschiedenis en de praktijk leert dat soldaten wel een vuist kunnen maken, indien zij zich kunnen verenigen en op deze wijze kunnen opkomen voor hun eigen belangen zonder daarbij de algemene belangen van de krijgsmacht te schadien.

Vooral voor dienstplichtigen is het belangrijk zich te kunnen verenigen, omdat dit eén van de weinige manieren is waarop zij hun onvrede naar voren kunnen brengen. $\mathrm{Z}_{\mathrm{ij}}$ kunnen namelijk geen ontslag nemen indien de situatie hun niet bevalt. Vrijwilligers kunnen dit wel. Het ontslagrecht van vrijwilligers brengt een nieuwe, meer economische dimensie aan de wisselwerking tussen maatschappij en krijgs-

$10_{\text {Idem, blx. } 47 \text {. }}$ 
macht. Dienstplichtigen moeten verplicht dienen, mogen geen ontsilag nemen en omdat ze ook nog eens goedkoop zijn, is de vervangingswaarde van een dienstplichtige laag. Is een dienstplichtige lastig of functioneert deze niet, dan is deze persoon snel vervangen door een nieuwe dienstplichtige. Zou de krijgsmacht met vrijwilligers gevuld worden dan is de situatie echter anders. Enerzijds omdat het duur is een vrijwilLiger te dumpen - war halen we immers zo snel een vervanger vandaan. Anderzijds omdat de krijgsmacht problemen krijgt met de opvulling van haar vacatures, indien de normen en waarden van de krijgsmacht afwijken van de normen en waarden in de maatschappij. De krijgsmacht kan zichzelf als werkgever de markt wit prijzen, indien geen rekenüng wordt gehouden met de wensen van de soldaten. Het mechanisme dat hiervoor beschreven is, is vergelijkbaar met het mechanisme dat beschreven is in paragraaf 6.4.1. In paragraaf 6.4.1. hebben we gezien dat een vrijwilligersleger minder snel in oorlog zal gaan dan een dienstplichtigenlleger, omdat de kans bestaat dat een vrijwilligersleger zonder personeel komt te zitten indien de oorlogsbeslissing niet meer gedragen wordt door de groep in de maatschappij die voor de soldaten moet zorgen. Bij onmenselijke behandeling van soldaten door hun meerderen kan het zelfde gebeuren. Druk van de arbeidsmarkt zal er toe leiden, dat de arbeidsvoorwaarden en arbeidsomstandigheden in brede zin overeen moeten komen met hetgeen elders in de maatschappij gebruikelijk is, omdat de krijgsmacht anders het gevaar loopt zonder personeel te komen. Bovendien zullen vrijwilligers ontslag nemen indien de arbeidssituatie ze niet meer bevalt.

Dit is echter geen absolute waarschijnlijkheid. Een aantal vrijwilligers zal een eventueel afwijkend werk- en leefklimaat accepteren, omdat zij nauwelijks alternatieven hebben op de arbeidsmarkt. Volgens de Maatschappelijke Raad voor de Krijgsmacht (MRK) zal dit voomamelijk laaggeschoolden betreffen. ${ }^{11}$ Afschaffing van de dienstplicht vraagt daarom volgens de Maatschappelijke Raad voor de Krijgsmacht om alertheid op dit gebied: het streven moet gericht zijn en blijven op representativiteit van de krijgsmacht, zowel naar normen als naar waarden als naar samenstelling. De MRK is voornamelijk bevreesd voor een situatie waarin het overgrote deel van de vrijwilligers voortkom wit een groep in de maatschappij die niet beïnvloed wordt door verschuivingen in opinies in de maatschappij. In termen van het mediane kiezersmodel wil dit zeggen dat deze groep vrijwilligers de drempel van bijvoorbeeld wel of geen oorlog voreren nooit zal overschrijden.

De bezorgdheid van de Maatschappelijke Raad voor de Krijgsmacht op dit punt is begrijpelijk. Toch zijn er in een vrijwilligersleger een aantal instrumenten in te bouwen, waarvan het ontslagrecht er een is, waardoor de druk van de arbeidsmarkt daadwerkelijk effect kan hebben. Deze instrumenten zorgen voor een automatische prikkel in de wisselwerking tussen maatschappij en krijgsmacht.

Zo zijn de taken van het nieuwe vrijwilligersleger een stuk uitgebreider dan de taken van het oude dienstplichtigenleger. Vrijwilligers dienen ook voorbereid te zijn op hun VN-taken. Juist deze VN-taken vragen om een hoger opleidingsniveau van de virijwilligers, welke door een initiêle opleiding reeds verkregen is of door bijscholing in de krijgsmacht wordt verkregen. Taken die ondermeer gericht zijin op overreding en overtuiging, vragen om mondiger sollaten dan vroeger noodzakelijk was. Bovendien zullen de nieuwe taken van de krijgsmacht de laaggeschoolden ook een stapje omhoog helpen op de maatschappelijke ladder waardoor de representativiteit van de krijgsmacht toeneemt.

\footnotetext{
${ }^{11}$ Maítschappelijke Raad voor de Krijgsmacht, Standpunt van de Maatschappelijke Raadi voor de Krijgsmacht over het advies van de commissie Mejier, advies nr. 26, Dan Haag 1992, blz. 12.
} 
Met andere woorden, er is wel degelijk plaats voor laaggeschoolden in een vrijwilligersleger. Indien de krijgsmacht de scholing van deze laaggeschoolden achterwege laat, heeft zij daar toch voornamelijk zichzelf mee, omdat zij dan moeilijker vrijwilligers zal kunnen werven en onvoldoende uitvoering kan geven aan met name de humanitaire $\mathrm{VN}$-taken.

Op dezelfde wijze waarop geacht wordt de invloed van de top van de hiërarchie te verminderen, door het middenkader onafhankelijker te maken, kan de onderkant van de hiërarchie op deze wijze ook onafhankelijker worden gemaakt.

Een laatste opmerking is dat het te verwachten is dat de militaire belangenbehartigingsorganisaties onverminderd blijven bestaan. Zij zullen naar alle waarschijnlijkheid de rechten van de vrijwilligers blijven behartigen en daarmee druk uitoefenen op de werkgever en de top van de hiërarchie in de krijgsmacht namens deze soldaten, om op deze wijze ook tegengas te kunnen geven.

\section{\$7.2. De privatisering van defensie}

In de krijgsmacht werken zowel burgers als militairen. In hoofdstuk 5 hebben we gezien dat afschaffing van de dienstplicht of het betalen en behandelen van dienstplichtigen als vrijwillige militairen, militaire arbeidskrachten duur maakt, waardoor zij beter vervangen kunnen worden door burgers op plaatsen waar dit mogelijk is. Door de vervanging van militairen door burgers treedt bovendien vermaatschappelijking van de krijgsmacht op, omdat de krijgsmacht in grotere mate afhankelijk wordt van burgers.

Uit maatschappelijk oogpunt worden dienstplichtigen vaak beschouwd als "burgers in uniform". Bij het verdwijnen van deze "burgers" treedt dus een verslechtering. op van de vermaatschappelijking van de krijgsmacht, indien we veronderstellen dat de verhouding burgers/militairen de mate van vermaatschappelijking van de krijgsmacht weergeeft. Dienstplichtigen dienen dus in dit geval niet beschouwd te worden als militairen, maar als burgers. Verbetering van de ratio levert maatschappelijke baten op en een verslechtering van de ratio is te beschouwen als een maatschappelijke last. Het verdwijnen van de dienstplicht verplicht de maatschappij de wisselwerking tussen maatschappij en krijgsmacht te verbeteren door nieuwe instrumenten voor deze wisselwerking in te zetten. Deze instrumenten dienen er voor te zorgen dat het aantal burgers dat direct hav invloed op de krijgsmacht kan laten gelden toeneemt in verhouding tot het aantal millitairen. Een van die instrumenten is privatisering. Boorsma omschrijft het begrip privatisering als volgt:

"Het meer inschakelen door de overheid van het particuliere initiatief" "12

Hieronder verstaat hij zowel de verzelfstandiging van delen van de collectieve sector, als het overhevelen van taken naar de particuliere sector, als ook de intensivering van het vrijwilligerswerk. ${ }^{13}$

\footnotetext{
12p.B. Boorsma, Privaltisering, Openbare Uitgaven 16, ni, 6 oktober 1984, bliz.. 284 .

13 Deze omschrijuing van het begrip privatisering zal in het vervolg wan dit hoofdstuk worden gebruikt. De omschrijving wijkt enigzins af van meer moderne omschrijvingen van het begrip privatisering, watbij verzelfstandiging als een aparte categorie wordt gezien en geen onderdel witmaakt van het begrip privatisering.
} 
In hoofdstuk 5 werd reeds gesproken over uitbesteding als de substitutie van dienstplichtigen door burgers en kapitaal. Feitelijk is uitbesteding slechts een onderdeel wan het grote begrip privatisering. Privatisering van de krijgsmacht is dus niet alleen van belang voor een verbetering van de wisselwerking tussen maatschappij en krïgsmacht, privatisering van de krijgsmacht kan ook een efficiëntieverbetering opleveren.

Privatisering van de krijgsmacht lijkt in eerste instantie nogal paradoxaal. Toch geeft de krijgsmacht alle mogelijkheden om privatisering toe te passen. Defensie is een collectief goed. ${ }^{14}$ Dit collectieve goed wordt betald uit de belastingopbrengsten van de overheid, doch hoeft niet per definitie ook geproduceerd te worden door de overheid. Dat het collectieve goed defensie geproduceerd wordt door de krijgsmacht, een onderdeel van de overheid, komt omdat de overheid het geweldsmonopolie bezit. Een nadere blik op de krijgsmacht laat ons zien dat de krijgsmacht zowel gevechtsfuncties als niet-gevechtsfuncties bezit. Omdat de gevechtsfuncties gekoppeld zijn aan het geweldselement dienen deze functies altijd bij de overheid te blijven. Privatisering in de vorm van het afstoten van taken is in deze onmogelijk. De niet-gevechtsfuncties in de krijgsmacht kennen de beperking van het geweldsmonopolie niet. Deze functies komen dan ook onverkort voor privatisering in aanmerking.

In paragraaf 7.2.1 gaan we nader in op de theoretische achtergronden van privatisering. In paragraaf 7.2.2. worden de theoretische uitkomsten toegepast op de krijgsmacht. Het doel van deze paragrafen is niet primair gelegen in het feit of de privatisering van de krijgsmacht efficiëntievoordelen oplevert. Om de juiste grootte van de efficiëntievoordelen te bepalen zal aan twee paragrafen niet voldoende zijn. Efficiëntieverbetering mag dan geen hoofddoel zijn, een nevenvoorwaarde is het zeker. Hoofddoel van de privatisering van de krijgsmacht is de verbetering van de wisselwerking tussen maatschappij en krijgsmacht. Of dit daadwerkelijk mogelijk is met behulp van privatisering, zullen we aan het einde van dit hoofdstuk zien.

\section{\$7.2.1. Privatisering: de theorie ${ }^{15}$}

Privatisering kan zich zowel aan de aanbodzijde als aan de vraagzijde van het economische proces voordoen. Bij privatisering aan de vraagzijde gaat het om toepassing van het profijtbeginsel. Dit wil zeggen dat de kosten van een overheidswoorziening geindividualiseerd kunnen worden en bij de gebruiker in rekening worden gebracht. Defensie als eindprodukt voor de consument is echter een zuiver collectief goed, waardoor toepassing van het profijtbeginsel onmogelijk is.

\footnotetext{
14 Zie ook hoofdstuk 2 .

15 Deiza paragraaf is gebaskerd op een auntal artkelen: E. Biesmeijer en W.C. Verbaan, Zelfbeheer It de ambtenaar wordlt mamager, Openbare Uitgaven, 16, n*. 5, septomber 1984, blz. 226-239; N.P. Mol, Zelfbeheer I: kostenplaatsenbudgettering, Openbare Uitgaven 16, nr. 5 , september 1984, blz. 240-256; N.P. Mol, Bedrijfseconomie van de collectieve sector, Alpen aan da Rijn, 1989; N.P. Mol en H.A.A. Verbon, Institutionele economie en openbaar bestutur, perspectieven op de verzels tandiging van overheidsdiensten, 's-Graventhage 1993; P.B. Boorsma, Privatisering, Openbare Uitgaven 16, nr 6, oktober 1984, bl2, 282-303; B.C.], van Velthoven en F.A.A.M. van. Winden, Privatisering, eer politiek-conomische benadering, Openbare Uitgaven 16, nr.6, oktober 1984, blz. 304317; P. Felix, Verzelistandiging alls privatiseringsvariant, Economisch Statistische Berichten, 5 maart 1986, blz. 248$252 ; \mathrm{E}$. Boneschansker en H. de Groot, Verzelfstandiging van overheidsdiensten: wanneer en hoe?, Openbare Uilgaven 24, nr.3, mei. 1992 ; D.J. Kraan, Bureaucratietheorie en organisatie wan de rijksdienst, Openbare Uitgaven 24, nr.4, jull 1992; R.H. Covase, The nature of the firm, Economica 4, 1937, blz. 386-405, R.H. Coase, Accounting and the theory of the firm. Journal of accounting and economics 12 (1990), blz. 3-13, R.H. Coase, The institutional structure of production, The American Economic Review, september 1992, blz. 713-719; N.P. Mol en H.A.A. Verbon, Institutionele conomie en openbaar bestuur, perspectieven op de verzelfstandiging van overheidsdiensten, 'sGravenhage, 1993.
} 
Bij privatisering aan de aanbodzijde valt te denken aan afstoting, uitbesteding en verzelfstandiging. Bij afstoting laat de overheid de taken geheel over aan de particuliere sector zonder zich verder met beleid en uitvoering te bemoelen. Bij uitbesteding blifft de overheid de omvang van de taken beleidsmatig bepalen, maar gaan delen van de uitvoering - in contract - over naar het particuliere bedrijfsleven. Bij verzelfstandiging worden taken overgedragen aan verzelfstandigde organisaties met een eilgen rechtspersoionlijkheid met indirect overheidstoezicht. De laatste vorm biedt de meeste mogelijkheden voor varianten.

Verzelfstandiging kan extern en intern plaatsvinden. In het geval van externe verzelfstandiging spreken we meestal van zelfstandige bestuursorganen. Zelfstandige of functionele bestuursorganen zijn privaat- of publiekrechtelijke organisaties die een zodanige zelfstandigheid hebben bij het uitvoeren van publieke taken dat er geen hiërarchische ondergeschiktheid is ten opzichte van een minister. In het geval van interne verzelfstandiging hebben we het over vormen van contractmanagement, zelfbeheer en agentschappen binnen de rijksdienst. De ministeriêle verantwoordelijkheid voor de uitgevoerde taken blijft volledig bestaan, terwijl de uitvoeringsinstanties meer ruimte krijgen om daarmee een meer efficiënte bedrijfsvoering te kunnen bewerkstelligen. Bij externe verzelfstandiging wordt het hiërarchisch toezicht opgeheven. Aan de opheffing van het hiërarchisch toezicht is het voordeel verbonden dat de daaraan verbonden kosten vervallen. Daar kan echter een stijging van de produktiekosten tegenover staan. Derhalve moet worden nagegaan onder welke voorwaarden per saldo een besparing optreedt.

Kraan ${ }^{16}$ formulleert de criteria voor externe verzelfstandiging als volgt:

1. De gewenste kwaliteit en kwantiteit van de geproduceerde voorziening moet in voldoende mate stabiel zijn;

2. De minister moet kunnen beschikken over actuele en betrouwbare informatie over de kosten per eenheíd van de geproduceerde voorziening;

3. Er moet een effectieve prikkel aanwezig zijn voor de leiding van de te verzelfstandigen dienst om naar efficiëntiewinst te streven.

Indien de gewenste kwaliteit of kwantiteit van het produkt afhankelijk is van snel veranderende en onvoorspelbare omstandigheden, is verzelfstandiging niet efficiënt vanwege transactiekasten. Het bestaan van transactiekosten bij handelingen kan betekenen dat alternatieve coördinatiemethoden te prefereren zijn boven het marktmechanisme, zelfs indien deze coördinatiemethoden kosten en imperfecties met zich meebrengen. Afzonderlijke overeenkomsten per levering met aanbieders van produktiefactoren en intermediaire produkten zouden immers kunnen leiden tot hoge (transactie)kosten. Indien de transactiekosten en imperfecties veel groter zijn dan de prijzen die het marktmechanisme genereert, geldt natuurlijk dat het hiërarchisch toezicht dient te verdwijnen.

Hiërarchisch toezicht is nodig indien we willen waarborgen dat een dienst op ieder moment produceert wat de minister wenst. Dit geldt met name in gevallen waarin beleidsvrijheid aanwezig is tijdens de begrotingsuitvoering.

Uit het tweede criterium vloeit voort dat het produkt goed meetbaar moet zijn en dat een bedrijfseconomische financiële administratie moet worden gevoerd op basis van het baten-lastenstelsel. Alleen op die wijze kan worden gewaarborgd dat de benodigde kosteninformatie permanent op basis van actuele gegevens kan worden geleverd. De besturing van de produktie kan slechts efficiënt zijn, als indicatoren rele-

16 Kraan, blz. 164-165. 
vante prestaties kunnen weerspiegelen. Ieder produkt dient goed gedefinieerd te zijn, watabil een bedrifseconomische administratie er tewens voor lan zorgen dat een duidelik inzicht wordt verkregen in de inteme transactiekosten die gemaakt worden om het produkt tot stand te brenger.

Kostprijsberekening binnen de collectieve sector is des te meer noodzakelik, omdat met behulp van de berekende kostprijzen beredeneerd kan worden, welke delen wan wen organisatie hierrarchisch bestuurd kunnen worden en in welke delen van de organisatie het marktmechanisme voorop staat. Op basis van een goed inzicht in de Kosten per eenheid is het mogelik de financiering van de verzelfstandigde dienst te baseren op nomkosten per eenheid. In verband hiermee is het nodig dat de verlangde prestuties worden vastgelegd in een juridisch afdwingbaar contract en dat aan extem verzelfstandigde diensten altijd rechtspersoonlijkheid wordt toegekend.

Het derde criterium komt erop neer dat bij de afwezigheid van hiërarchisch toezicht een andere prikkel aanwezig moet zijn, waardoor overwinsten van de verzelfstandigde dienst worden geelimineerd. Dit is nodig omdat financiering op basis van normkosten nog geen doelmatig produktieproces garandeert. Daartoe is informatie over de gemiddelde kosten vereist die niet uit de financiële administratie kan worden afgeleid, ook niet als deze op bedriffseconomische wijze is ingericht. Er kan immers een verschil bestaan tussen de zichtbare kosten en de zuivere kosten. Dit verschil kan onder meer worden toegeschreven aan de informatievoorsprong die een dienstleiding vak heeft en aan het feit dat de dienstleiding gebruik kan maken van haar machtspositie om een prijs te bedingen die uitgaat boven de kosten waarover de politicus informatie heeft. Deze situatie komt overeen met de kenmerken van het bilateraal-monopoliemodel van Niskanen, zoals beschreven in hoofdstuk 2 .

Het probleem van de overwinsten kan worden opgelost door het persoonlijk inkomen van de dienstleiding op enigerlei wijze te koppelen aan het verschil tussen het toegekende budget en de zichtbare kosten: de zogenoemde "efficiëntiewinst". Een systeem waarbij volkomen concurrentie optreedt, biedt daartoe de beste mogelijkheden. Volkomen concurrentie introduceert een aantal prikkels die er voor zorgen dat eventuele overwinsten op den duur verdwijnen. De vraag rijst echter of vergelijkbare prikkels bij verzelfstandiging binnen de collectieve sector mogelijk zijn.

Een manier waarop aan de efficiëntieprikkels zou kunnen worden vormgegeven, is door te bepalen dat de verzelfstandigde dienst een deel van deze winst "zelf mag houden". Hiermee wordt dan bedoeld dat een deel van het verschil tussen het toegekende budget en de zichtbare kosten ter vrije besteding van de dienst worden gesteld, echter zondet dat deze middelen aan het inkomen van de dienstleiding mogen worden toegevoegd. Dit leidt echter niet tot een effectieve oplossing. Ten eerste zou deze prikkel tot zuivere verkwisting leiden, aangezien de vrije besteding per definitie tot ondoelmatige aanschaffingen of een politiek ongewenst, namelijk te hoog, produktieniveau leidt. Ten tweede kan deze prikkel per definitie niet effectief zijn. Immers de leiding van een verzelfstandigde dienst zal er nooit toe overgaan om (onzichtbare) overwinst om te zetten in (zichtbare) efficiëntiewinst, indien dit impliceert dat slechts een deel van deze winst ter vrije besteding staat. Indien deze winst als onzichtbare overwinst wordt opgenomen staat immers $100 \%$ ter vrije besteding.

Een mogelijkheid om vorm te geven aan de efficiëntieprikkel die soms wel tot goede resultaten leidt is de overheids-NV. Daartoe is dan wel nodig dat de overheid een marktconform dividend verlangt. De overheids-NV dwingt tot een nauwkeurige registratie van de gerealiseerde efficiëntiewinst en het feit dat eventuele afwijkingen van een marktconform dividend openbaar zijn werken in de praktijk als belangrijke prikkels. Doordat de directie van een overheids-NV is vrijgesteld van de gebruikelijke 
ambtelijke arbeidsvoorwaarden, is het daamaast mogelijk om een relatie te leggen tussen de gerealiseerde efficiëntiewinst en het persoonlijk inkomen van de bedrijfsleiding. Een aparte vraag is dan hoe na verzelfstandiging structureel te hoge marges van efficiëntiewinst kunnen worden voorkomen. Daarvoor kunnen een aantal methoden worden gebruikt.

De eerste methode sluit aan bij een systeem van volkomen concurrentie waarbij gedwongen winkelnering uitgesloten is. Een tweede methode is prijsregulering. Door externe verzelfstandiging binnen de collectieve sector, dus in de vorm van een zelfstandig bestuursorgaan, overheids-NV of overheidsstichting, is bovendien een automatisch mechanisme ingebouwd, daar efficièntiewinsten - die per definitie zichtbaar zijn - in beginsel via budgettaire ombuigingen of dividenduitkeringen weer worden toegevoegd aan de algemene middelen.

Structureel te hoge winstmarges kunnen ook ontstaan ten koste van de inputfactoren, arbeid en kapitaal. Dit kan tot gevolg hebben dat de kwaliteit van het produkt op lange termijn onder druk kan komen te staan. Kwaliteitscontrole zowell ten aanzien van de "inputfactoren", de "output", als het produktieproces is een essentieel onderdeel van een privatiseringsproces. Zonder deze controles kan een privatiseringsproces spaak lopen. Er zal dan ook een formele basis aanwezig moeten zijn om de kwaliteit te garanderen. Zo is het heel goed voor te stellen dat efficiëntiewinst slechts wordt uitgekeerd aan de leiding van een eenheid, indien dit de goedkeuring kan verdragen van de kwaliteitscontroleurs. Voorbeeld van zo'n kwaliteitsbewaking kan een Raad van Commissarissen zijn.

De angst dat omvangrijke efficiëntiewinsten verdwijnen in de zakken van private ondernemers is waarschijnlijk een belangrijke reden waarom in de praktijk nogal eens de voorkeur gegeven wordt aan externe verzelfstandiging in de vorm van een zelfstandig bestuursorgaan of an interne verzelfstandiging boven privatisering. Te bedenken echter valt dat de afwezigheid van een adequate efficiëntieprikkel bij verzelfstandiging binnen de collectieve sector de kosten per eenheid produkt veel nadeliger kan beinvloeden dan het accepteren van een beperkt zichtbare - en daardoor beheersbare - winstmarge in verzelfstandigde diensten.

$\mathrm{Bij}$ externe verzelfstandiging doet het in principe weinig ter zake of er sprake is van een $100 \%$ overheidsdeelname of niet. De essentie ligt in de overeenkomsten of contracten tussen de overheid en de verzelfstandigde dienst. Daarnaast kunnen financieringsdoeleinden - bijvoorbeeld minder beslag op de overheidsmiddelen bij investeringen - een reden zijn de particuliere sector in de produktie te betrekken.

De verschillen tussen interne verzelfstandiging en externe verzelfstandiging blij" ven beperkt indien aan de interne verzelfstandiging vorm wordt gegeven door het laten vervallen van het hiërarchisch toezicht op beslissingen van de dienstleiding over afzonderlijke apparaatuitgaven. De dienstleidung krijgt in deze de beschikking over een ongedifferentièerd budget. Dit impliceert dat ter waarborging van de doelmatigheid van het produktieproces dezelfde eisen moeten worden gesteld als bij externe verzelfstandiging, behoudens het feit dat rechtspersoonlijkheid van de dienst niet nodig is om sanctionering van een wanprestatie mogelijk te maken. Een soort van rechtspersoonlijkheid is echter wel nodig, willen we een adequate efficièntieprikkel beschikbaar hebben die bij interne verzelfstandiging de overwinsten afroomt. Hiervoor is de rechtsvorm van het "agentschap" voorgesteld. Of deze in praktijk ook echt effectief is, is vooralsnog niet bekend.

Wil afstoting, uitbesteding, en verzelfstandiging een succes zijn, dan zijn een aantal succesvoorwaarden nodig om deze vormen van privatisering ingevoerd te krijgen. De belangrijkste zijn: 
- de ambtelijke top moet het systeem als nuttig ervaren

- de medewrerkers van de dienst moeten er belang bij hebben

- de taakstelling van de output dient woor de betrokken partijen duidelijk te zijn en

- ex moet een goed management-informatiesysteem zijn op grond waarvan de dienst en de leiding beheersmaatregelen kunnen nemen.

Daarnaast zal de cultuur van zo'n dienst ook dienen te veranderen. De organisatiecultuur van een conditionerende, regelende en controlerende overheid verdraagt zich immers niet met een cultuur die nodig is om op effectieve en efficiënte wijze concrete produkten en diensten te leveren. De praktijk laat zien dat juist culturele factoren de oorzaak zijn van het mislukken van vele reorganisaties waarvan privatisering erén is.

Privatisering is een ingewikkeld proces en vindt niet plaats vanwege de algemeen theoretische argumenten pro en contra, maar omdat politici en ambtenaren daartoe gedwongen worden of zich gedwongen voelen. Indien ze zich niet gedwongen voelen kunnen namelijk de argumenten tegen privatisering de overhand krijgen. Zo kan privatisering een verlies aan banen bij de overheid betekenen. Daarnaast kan serviceverlies optreden. Een derde reden tegen privatisering is dat dit enorm kostbaar kan zijn. Gesteld wordt ondermeer dat het voor kan komen dat een bedrijf inschrijft tegen een te lage prijs waarop het contract wordt verkregen. Na enige tijd wordt de prijs verhoogd. Aangezien dan inmiddels bij de witbestedende partij de eigen kennis en technologie verdwenen is om het werk zelf te doen, is de overheid gedwongen de prijsverhoging te accepteren. Een vierde argument dat wordt gehanteerd is dat bedrijven zich weinig gelegen laten liggen aan niet-bedrijfseconomische waarden, zoals een schoon milieu en een vijfde argument tenslotte is gelegen in het sociale beleid: een particulier bedrijf zal eerder zijn personeel extra belasten en ook gemakkelijker ontslaan dan een overheidsdienst. Deze argumenten zijn in de praktijk van alle dag van wezenlijk belang.

In hoeverte de in deze paragraaf beschreven theorie ook toepasbaar is in de krijgsmacht is het onderwerp van de volgende paragraaf.

\section{\$7.2.2. De privatisering van de krijgsmacht}

Willen we de theorie, beschreven in paragraaf 7.2.1., in de praktijk toepassen, dan is het noodzakelijk de kernelementen van de theorie goed onder de loep te nemen. Hierbij volgen we de criteria die door Kraan zijn opgesteld.

Voorop gesteld is dat de gewenste kwaliteit en kwantiteit van de geproduceerde voorzlening, in ons geval defensie, in voldoende mate stabiel zal moeten zijn. Hoewel de laatste jaren de internationale velligheidssituatie volop in beweging is en daardoor het collectieve goed defensie een iets ander jasje krijgt, is er geen sprake van instabiliteit ten anzien van de voorziening. In de kern beschouwd zal er altijd bescherming tegen invloeden van buitenaf noodzakelijk zijn. De stabiliteit van het collectieve goed defensie kan in de huidige omstandigheden als voldoende worden gezien.

Dit biedt ons de mogelijkheid de overige elementen te analyseren. Bij de analyse zal een globale schets worden gegeven. Een gedetailleerde aanpak is zeker mogelijk, maar gaat de strekking van deze paragraaf te boven. Doel is het algemene kader van de privatisering van de krijgsmacht te schetsen om daarmee aan te tonen of privatisering de wisselwerking tussen maatschappij en krijgsmacht kan verbeteren. 
De eerste stap bestaat daarbij uit het definiëren van het eindprodukt van de krijgsmacht op een zodanige wijze dat deze ook gemeten kan worden. Uit de definitie van het eindprodukt kunnen vervolgens een aantal intermediaire produkten worden afgeleid welke noodzakelijk zijn om het eindprodukt daadwerkelijk tot stand te laten komen. Vervolgens dienen aan de verschillende produkten kostprijzen gekoppeld te worden. Om deze kostprijzen per eenheid produkt te kunnen berekenen dient de financiële administratie zo ingericht te zijn, dat deze administratie in staat is om kostprijzen te kunnen genereren. Voor zover de krijgsmacht nog een kasboekhouding hanteert zal deze financiële administratie omgezet moeten worden in een bedrijfseconomische financiële administratie op basis van een baten-en lastenstelsel.

De derde stap is vervolgens dat de krijgsmacht wordt opgedeeld in verschillende diensten- en produktiecentra, die intern of extern verzelfstandigd worden. Waar dat mogelijk is zullen diensten uitbesteed kunnen worden. Tenslotte moet een invulling worden gegeven aan de instanties die de kwaliteitsbewaking op zich zullen nemen.

De krijgsmacht produceert gevechtskracht. Gevechtskracht is een abstract produkt welke geleverd wordt aan een niet alledaagse markt: de veiligheidsmarkt. Gevechtskracht ontstaat door de aanwezigheid van kapitaal en arbeid. Willen we gevechtskracht meten dain stuiten we echter op problemen. Gevechtskracht is niet direct meetbaar, waardoor we op zoek moeten naar een alternatieve meetwijze, welke een indicator kan opleveren voor het abstracte begrip gevechtskracht.

Gevechtskracht is nodig om eventuele vijanden buiten de deur te houden. Wil dit daadwerkelijk succesvol zijn, dan betekent dit dat de krijgsmacht inzetbaar moet zijn op een zodanige wijze dat zij de vijand kan weerstaan. De combinatie van kapitaal en arbeid moet zijn vruchten kunnen afwerpen, wil gesproken kunnen worden van een daadwerkelijke inzetbaarheid wan de krijgsmacht. Om de vijand te kunnen weerstaan zal een krijgsmacht moeten oefenen. Door dit oefenen, zal zij op een gegeven moment zoveel kwaliteit bezitten dat zij ingezet kan worden binnen een bepaald tijdsbestek en zo sterk is dat zij de vijand kan weerstaan. Met andlere woorden het aantal oefendagen kan gezien worden als een indicator voor het produkt gevechtskracht. Hoeveel oefendagen voor ieder onderdeel noodzakelijk is om het stempel voldoende gevechtskracht mee te krijgen is natuurlijk verschillend. Bij een definiëring van het produkt gevechtskracht kan het aantal oefendagen dat reeds gewoon is per onderdeel als uitgangspunt dienen.

In een statische toestand zouden we voor de gevechtskracht voldoende hebben aan het reeds aanwezige personeelsbestand en materieel. Echter oefenen kost tijd, en met het voortschrijden van de tijd lopen contracten van het personeel af, gaat materieel kapot en moet er ook materieel vervangen worden door veroudering. Daarnaast zal er tijdens het oefenproces uitgebreid gebruik worden gemaakt van diverse grond-en hulpstoffen, zoals voeding, kleding, benzine, ten einde alles goed te laten functioneren.

Wil een produktie-eenheid, zoals een brigade of een geneeskundig bataljon, goed kunnen functioneren dan heeft zij intermediaire produkten nodig die dienen als "input". Ook deze produkten dienen op enigerlei wijze geproduceerd te worden.

Bij een nadere kijk op de intermediaire produkten nemen we eerst de kapitaalszijde van het gevechtskrachtproduktieproces onder de loep. In de krijgsmacht wordt gebruik gemaakt van gebouwen, terreinen en machines. Deze materiële produkten. zijn gemakkelijk te onderscheiden. Ze zijn niet abstract, maar reẻel aanwezig. Zo ook de gebouwen in de krijgsmacht. 
Het bouwen wan kazernes, onderhoudsplaatsen, hangars eriz. kost geld, maar ook heit onderhoud aan 11 deze gebouwen moet in rekening worden gebracht. De kosten van de gebouwen kunnen worden omgezet in een kostprijs per eenheid gebruik van een gebouw. Deze kostprijs kan vervolgens dienen als normprijs voor een ieder die een gebouw of een deel van een gebouw wil gebruiken. De normprijs kan door een gebouwendienst in rekening worden gebracht bij de afnemer. Bij het opstellen van de waarde van een gebouw om de kostprijs te berekenen, kunnen de "opportunity costs" van zo'n gebouw als uitgangspunt dienen. Dit om problemen bij het opstellen van de kostprijs van deze gebouwen zoveel mogelijk op te lossen.

Bij de keuze voor welke vorm van privatisering een gebouwendienst in aanmerking komt, is het goed eerst even te kijken naar de algemene veiligheidsrisico's die eigen zijn aan de krijgsmacht. De krijgsmacht dient ons tegen externe factoren te beschermen. De vijand, concurrent, dient buiten de deur te wordien gehouden. Zij mag niet op de hoogte zijn op welke wijze de krijgsmacht haar strategie en primaire uitvoering bepaalt. Des te verder een onderdeel van het strategisch besluitvormingsproces af staat, des te minder zal het noodzakelijk zijn deze onder direct hiërarchisch toezicht te plaatsen. In het strategische besluitwormingsproces staat de aanwending van de combinatie van kapitall en arbeid, gevechtskracht, centraal. Zonder strategie van de krijgsmacht is een tark eigenlijk niets anders dan een hoop staal op rupsbanden, waarmee weinig begonnen kan worden. Vele produkten voor de krijgsmacht worden niet door de krijgsmacht zelf gemaakt, maar door bedrijven. Bedrijven die belang hebben bij eigenhandige bescherming van hun produkten, daar anders de concurrent er mee van door gaat.

Indien we op basis van het veiligheidsrisico een indeling maken van onderdelen die in een bepaalde vorm geprivatiseerd kunnen worden, dan zal de strategieafdeling altijd onder het ministerie blijven vallen. De gevechtseenheden komen voor interne verzelfstandiging in aanmerking, ook al omdat zij directe aanwijzingen van de politiek kunnen verwachten en zij beschikken over de mogelijkheden het geweldsmonopolie tot uitdrukking te brengen. Direct hiërarchisch toezicht is in deze noodzakelijk. De toeleveranciers aan de gevechtseentheden komen voor externe verzelfstandiging in aanmerking, waarbij gedacht kan worden aan uitbesteding, indien een grote mate van concurrentie bij de toelevering van die speciale diensten tot de mogelijkheden behoort. Een gebouwendienst kan door middel van externe verzelfstandiging geprivatiseerd worden, daar het veiligheidsrisico hier laag ligt. Gebouwen worden door private aannemers gebouwd, terwill deze aannemers voor gespecialiseerde produkten huin comparatieve voordeel ten opzichte van andere aannemers, die zij door de bouw kunnen krijgen, niet verloren willen laten gaan door onvoorzichtigheid. Daarnaast is het voor een gebouwendienst wenselijk om op een externe wijze verzelfstandigd te worden, omdat zij op deze wijze in haar financieringswijzen wordt versterkt. In de rechtspersoonlijkheid van een overheids-NV is zil namelijk gemakkelijker in staat leningen af te sluiten op de kapitaalmarkt.

Juist voor een dienst waarvan het produkt een investeringsgoed is, is het noodzakelijk dat externe financiering tot de mogelijkheden behoort, omdat de dienst op deze wijze flexibel om kan gaan met veranderingen in de markt. De markt is in dit geval de markt voor veiligheid.

Wil de Defensiegebouwendienst-NV efficiënt kunnen werken, dan is het noodzakelijk dat er voldoende prikkels binnen de dienst aanwezig zijn om tot efficiënt handelen te kunnen komen. De theorie zegt dat voor het instellen van prikkels het persoonlijk inkomen van de leiding gekoppeld dient te worden aan de efficiēntiewinst van een dienst wil de efficiëntiewinst boven water kunnen komen. Deze theoretische 
stelregel zal dan ook in de praktijk ingevoerd moeten worden. Wel is het zo dat voldoende "checks-and-ballances" in het systeem moeten worden ingebouwd, die er voor zorgen dat de winst niet ten koste is gegaan van personeel en kwaliteit van de gebouwen.

De kwaliteitscontrole ten aanzien van het personeel kan bijvoorbeeld geregeld worden door het personeel op te nemen in de Raad van Commissarissen van de Defensiegebouwendienst-NV, die uiteindelijk moet beslissen over de toekenning van een deel van de efficiëntiewinst aan de leiding van de Defensiegebouwendienst- $N$. Ook kan in een Raad van Commissarissen ruimte worden gemaakt voor leden van de Algemene Rekenkamer, het Ministerie van Defensie en het parlement om de kwaliteitsgaranties te kunnen waarborgen.

De kwaliteit van de Defensiegebouwendienst-NV stat tevens onder controle van haar afnemers. Dit kunnen de gevechtseenheden zijn, maar ook andere gebruikers. Probleem in de relatie tussen de afnemers en de Defensiegebouwendienst- $N V$ is dat vaak sprake zal zijn van gedwongen winkelnering en een situatie van een bilateraalmonopolie niet te vermijden valt. Dit komt omdat er sprake is van slechts eên aanbieder en één afnemer. Zo kunnen gevechtseenheden zich niet zomaar overall vestigen en hebben de gebouwen van de Defensiegebouwendienst-NV soms zulke specifieke kenmerken dat altematieve aanwending onmogelijk is. Het marktmechanisme zal haar werk niet goed kunnen doen, waardoor een bepaalde mate van prijstegulering is geboden. In deze is de taak van de Raad van Commissarissen van de Defensiegebouwendienst- $\mathrm{NV}$, maar ook de taak van de Raad van Commissarissen van de afnemer, goed te letten op het feit dat de norm- of interne verrekenprijzen riet de uitkomst zijn van scheve machisverhoudingen.

Een ander noodzakelijk intermediair produkt is het gebruik van terreinen. Terreinen dienen oefenrijp te zijn voordat ze gebruikt kunnen worden. Ook zullen terreinen gebruikt worden voor de bouw van kazernes en andere gebouwen. In dit geval is de Defensieterreinendienst-NV toeleverancier van de Defensiegebouwendienst-NV. Prijsafspraken dienen gebaseerd te zijn op de normkosten per eenheid terrein, waarbij enige mate van prijsregulering ook hier noodzakelijk zal zijn. Deze prijsregulering thoeft natuurlijk niet te gelden voor de prijzen die toeleveranciers de Defensieterreinendienst-NV in rekening brengen voor verrichte diensten, zoals de bewaking van de terreinen en de aanleg van wegen. De Defensieterreinendienst-NV kan geprivatiseerd worden door middel van externe verzelfstandiging. $\mathrm{Zij}$ zal op de zelfde wijze geleid en gecontroleerd kunnen worden als de DefensiegebouwendienstNV.

Een derde groep produkten aan de materieelkant van het krijgsmachtbedrijf is het machinebestand dat nodig is om alle produkten in de krijgsmacht te kunnen maken. Onder deze machines vallen niet alleen de tanks, F-16-gevechtsvliegtuigen en fregatten, maar dient ook gedacht te worden aan de heftrucks in de magazijnen, de computers in de defensiekantoren en de software voor deze computers. Het gaat hier dus om de in principe mobiele kapitaalgoederen die worden verstrekt door een materieelbedrijf en gebruikt worden door de diverşe krijgsmachtdelen.

Externe verzelfstandiging in de vorm van een Defensilemachinepark-NV is ook hier de geëigende weg om op efficiënte wijze om te kunnen gaan met de machines. Bovendien kan deze Overheids-NV flexibeler omgaan met investeringsverzoeken uit 
andere delen van de krijgmacht, omdat externe verzelfstandiging haar de mogelijkheid biedt om externe financiering te gebruiken. ${ }^{17}$

De vierde groep produkten zijn de grond- en hulpstoffen die nodig zijn voor de produktie van gevechtskracht. Het gaat hierbij om verbruiksgoederen, zoals kleding, kerosine, kantooraccessoires enz. De dienst die deze produkten dient te leveren is feitelijk weinig anders dan een inkoopbureau vergelijkbaar met het Rijksinkoopbureau. Zij huurt haar gebouwen van de Defensiegebouwendienst-NV, de machines van de Defensiemachinepark-NV en de terreinen van de Defensiegebouwendienst-NV. De logistieke taak vain de Defensiegoederendienst-NV kost geld. De kosten wan deze taak komen daarom ook terug in de prijzen, welke zil in rekening brengt aan haar afnemers. Of de prijzen van de Defensiegoederendienst-NV de juiste prijzen zijn, kan worden achterhaald door de prijzen te vergelijken met de prijzen van branchegenoten in de burgermaatschappij. Ook bij de controle van alle overige Defensiebedrijven is dit een manier om te zien of er geen misbruik wordt gemaakt van bepaalde monopoliesituaties of machtsverhoudingen.

Tot nu toe hebben we vier Defensiebedrijven beschouwd. Drie van de bedrijven gingen om met investerings- of kapitaalgoederen. Willen we kapitaalgoederen in een goede conditie houden, dan is adequal onderhoud noodzakelijk. Zowel de gebouwen, als de terreinen, als de machines kunnen zonder onderhoud niet lang overleven. Onderhoudsbedrijven zijn in grote aantallen aanwezig in de maatschappij. Hoewel niet ieder bedrijf direct de kennis zal hebben om F-16-gevechtsvliegtuigen te onderhouden, is een grote mate van mededinging op de onderhoudsmarkt te verwachten. Daar het onderhoud nog een stapje verder weg is van het terrein van de strategische besluitvorming, is het onderhoud een deel van het krijgsmach bedrijf dat uitstekend door het particuliere initiatief kan worden gedaan. De privatiseringsvorm van uitbesteding komt hier het meest voor in aanmerking. Concurrentie zal er in deze voor zorgen dat de prijzen van het onderhoud een reelle basis zullen hebben. Er is in deze dan ook geen extra toezicht nodig op de kwaliteit, zoals dit bij de Defensiebedrijven wordt voorgestaan. Voldoet een onderhoudsbedrijf niet, dan moet de vervanger in feite al klaar kunnen staan. De kosten van onderhoud zullen in rekening worden gebracht bij de Defensiebedrijven. Deze zullen de kosten weer doorberekenen aan hun afnemers.

Schematisch kunnen we het verband tussen gevechtseenheden, Defensiebedrijven en onderhoudsbedrijven weergeven, zoals is gedaan in schema 7.1. De ononderbroken pijlen in dit schema geven de richting van de goederenstromen aan. De onderbroken pijlen geven de geldstromen weer.

Het schema is zeker niet compleet, omdat het de ondlerlinge goederenstromen tussen de diverse Defensiebedrijven niet weergeeft. Bovendien kan het zo zijn dat de onderhoudsbedrijven op hun beurt ook weer gebruik maken van gebouwen en machines die in bezit zijon van respectievelijk de Defensiegebouwendienst-NV en de Defensiemachinepark-NV. Daarnaast zijn er ook altijd nog de aannemers, de wapenproducenten, bewakingsdiensten enz., die ook een plaats in het schema hebben.

17 De Nederlandse krijgsmacht is nomenteel (1993) verwikkeld in een grote reorganisatie om haar nieuwe taken to kunnen uitwoeren. Voor deze nieuwe taken zijn vele nieuwe investeringen nodigg die niet betaald kunnen worden uit do aanwezige begroting. De investeringen worden nu verspreid over een groot aantal begrotingsjaren. Dit betekent echter wel dat een auntal taken blift liggen, waarvan de noodzaak madrukkelijk aanwezig is.

Bovendien zitten eenheden zonder de noodzakelijk materiêle ondersteuning waardoor de waarde van hun output

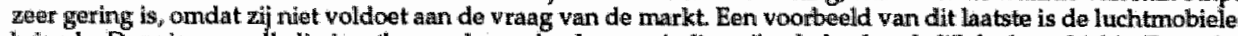
brigade. Deze is pas wolledig inzetbaar volgens de plannen, indien zij cok daadwerkelijk luchtmobiel is. Door de afwezigheid van helicopters productert zij in feite niets. Daar kan pas verandering in komem indien de helicopters komen of de doelen wan de luchtmobiele brigade worden herzien. 


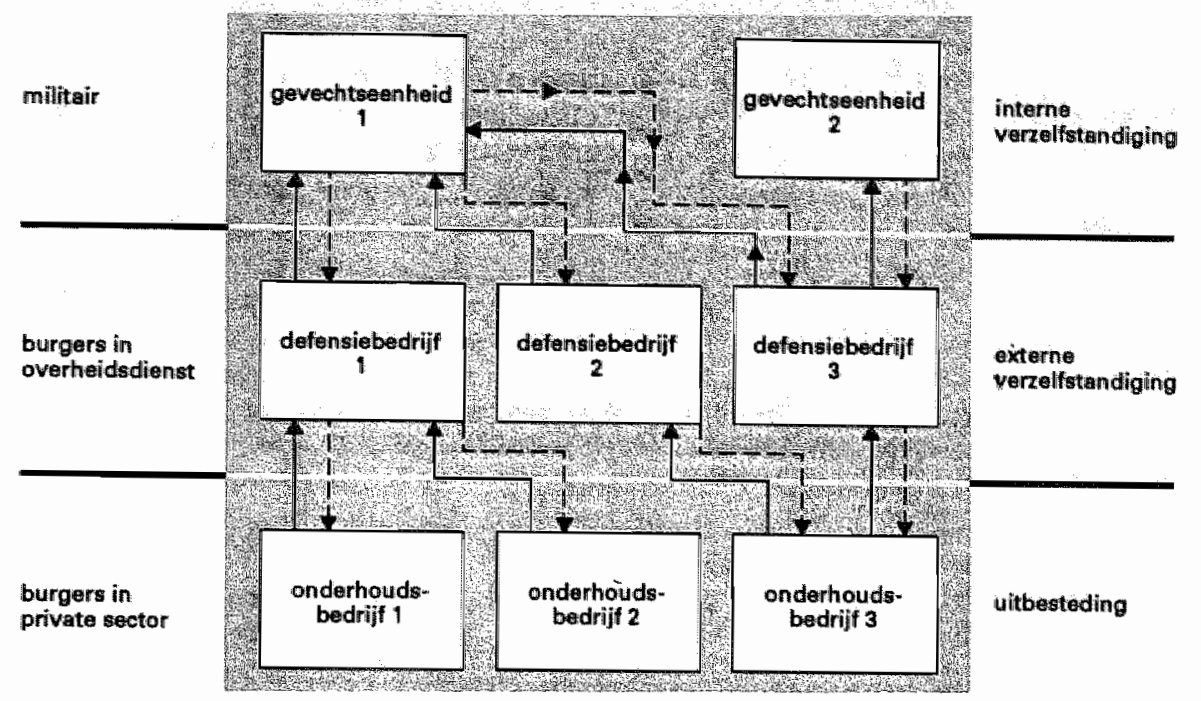

schema 7.1 Het verband tulssen gevechts defensiebredrijven en onderhoudsbedrijven

Aan de personele kant zijn, op dezelfde wijze als bij de kant van het materieel is gebeurd, ook een aantal intermediaire produkten te onderscheiden. Deze intermediaire produkten zullen we analyseren aan de hand van de levenscyclus van een militair. Deze levenscyclus begint bij de werving en selectie van een militair. Vervolgens moet een militair worden opgeleid, wil hij aan de functievereisten voldoen die nodig zijn voor het leveren van voldoende gevechtskracht. Na zijn opleiding komt de militair in actieve dienst om vervolgens de dienst te verlaten omdat de militair met pensioen gaat of omdat hij vertrekt naar een functie in de burgermaatschappij.

In hoofdstuk 6 hebben we langdurig stil gestaan bij het vraagstuk van de werving en selectie van militairen. Eén van de problemen die we daar geconstateerd hebben is dat de wensen van de militair niet altijd op de juiste wijze worden opgepikt door de krijgsmacht. Daarnaast wordt een groot deel van de vrijwilligers afgewezen, terwijl daar eigenlijk helemaal geen reden toe is. De oorzaak van de onverschilligheid in dit beleid ligt voor een deel bij het ontbreken van prikkels om daadwerkelijk efficiënt te handelen. Prikkels die ondermeer ontbreken door het bestaan van de dienstplicht.

De werving van nieuwe vrijwilligers kost geld. Kostbare reclamecampagnes worden opgezet om vrijwilligers te werven. De selectie van de vrijwilligers kost ook geld. Naarmate er meer vrijwilligers worden afgewezen zal het noodzakelijk zijn meer geld te steken in wervingscampagnes en selectiewerkzaamheden. Indien er geen prikkels zijn om het verschil tussen werkelijke kosten en budget te maximaliseren zal dit proces doorgaan tot het moment waarop het budget op is. Bureaucraten streven naar budgetmaximalisatie en in hun streven hiernaar zullen zij argumenteren dat de kwaliteit van de geworven soldaat boven alles gaat. Dit ondanks de praktische constatering ${ }^{18}$ dat de kwaliteit van soldaten slechts zeer weinig verschilt en mocht er daad-

18 Zie hoofdlstuk 6 , paragraaf 3.1 . 
werkelijk een verschil zijn dan is dit verschil vaak weg te werken door middel van extra scholing.

Indien de werving en selectie als een apart produkt wordt opgevat kunnen we zien welke mogelijkheden er zijn om dit proces te verbeteren. Werving en selectie hebben tot doel te komen tot een vrijwilliger welke geschikt is om opgeleid te worden tot militair, of om direct ingezet te worden in een ander Defensiebedrijf. De kosten die voor de werving en selectie worden gemaakt kunnen worden omgezet in een kostprijs per geschikt gevonden vrijwilliger. Deze normprijs wordt vervolgens in rekening gebracht bij de afnemer in het krijgsmachtbedrijf. Indien de wervings- en selectiedienst wordt yormgegeven in een overheids-NV komt de leiding van het Wervingsen Selectie-instituut-NV in aanmerking voor een deel van de efficiëntiewinst van het instituut. Als zij dan daadwerkelijk gevoelig is voor deze winst zal zij er toe overgaan sneller vrijwilligers geschikt te verklaren, omdat op deze wijze haar kosten worden gedrukt. Het toewijzeri van de efficiëntiewinst aan de leiding van het Wervings- en Selectie-instituut-NV zorgt woor een prikkel om op het oog minder geschikte vrijwilligers toch in dienst te nemen.

In dit proces heeft het Wervings- en Selectie-instituut-NV niet geheel de vrije hand, omdat zij wel degelijk afhankelijk is van haar afnemers. Zo zullen het Defensieopleidingsinstituut-NV en ook de gevechtseenheden tegengas proberen te geven om een al te lage kwaliteit aan recruten te voorkomen, omdat dit tot grotere aantallen uitvallers leidt. Uitvallers moeten weer vervangen worden en voor deze vervanging dient natuurlijk betaald te worden. Anderzijds hebben het Defensieopleidingsinstituut-NV en de gevechtseenheden natuurlijk ook voordeel bij een lage kostprijs van een geschikte kandidaat. Met name de gevechtseenheden zullen hier voordeel bij hebben, omdat aan een lage kostprijs van een geschikte kandidaat ook een laag salarispeil gekoppeld is. ${ }^{19}$ Het Defensieopleidingsinstitutut-NV kent deze prikkel in iets mindere mate omdat een vrijwilliger slechts korte tijd in opleiding is. Doch ook zij hebben als afnemer van het Wervings- en Selectieinstituut-NV baat in de salarissfeer bij een lage kostprijs van een geschikte kandidaat.

Het Wervings- en Selectie-instituut-NV kan geprivatiseerd worden door middel van externe verzelfstandiging. De controle op de kwaliteit is grotendeels al via het marktproces geregeld, doch gezien de geringe hoeveelheid afnemers is het raadzaam om ook hier een belangrijke rol toe te wijzen aan de Raad van Commissarissen bij het kwaliteitsproces.

Nadat een vrijwilliger geschikt is bevonden zullen velen doorgaan naar het opleidingsinstituut om opgeleid te worden tot soldaat, officier of een andere functie welke nodig is binnen het krijgsmachtbedrijf. Het Defensieopleidingsinstituut-NV heeft als produkt een opgeleide vrijwilliger. De opleidingen zullen verschillen naar functie. Door de functievereisten per functie als uitgangspunt te nemen zullen een aantal aktiviteiten ondernomen moeten worden wil een geschikte vrijwilliger het stempel opgeleid meekrijgen. De functievereisten zullen per functie verschillen. Dit betekent dat de kosten per opgeleide vrijwilliger ook zullen verschillen. Indien de leiding van het Defensieopleidingsinstituut-NV geprikkeld wordt door de toewijzing van mogelijke efficiëntiewinst, zal zij waken voor het feit dat vrijwilligers aktiviteiten moeten verrichten die niet overeenkomen met de functievereisten voor een bepaalde functie. Enerzijds kosten die overbodige aktiviteiten de leiding geld, maar anderzijds

\footnotetext{
${ }^{19}$ Hot afwijzen wan vrijwilligers heeft tot gevolg dat nieuwe wrijwilligers in een hoger salarissegment moeten worden gezocht. Het eerder aannemen van vrijwilligers bespaart niet alleen wervingskosten, maar zorgt tevens voor het afromen wan een lager deel wan het arbeidsaanbod.
} 
kunnen die activiteiten er tevens toe leiden dat de vrijwilliger afvalt waardoor de kosten nog meer toenemen.

Vanuit de afnemers van het Defensieopleidingsinstituut-NV zal er ook een prikkel komen de kostprijs van een opgeleide vrijwilliger zo laag mogelijk te houden, zodat er ook van die kant druk komt de opleiding te beperken tot de strikt noodzakelijke aktiviteiten voor de functievervulling.

Het produkt van het Defensieopleidingsinstituut-NV is niet beperkt tot het opleiden van vrijwilligers. $\mathrm{Zij}$ heeft ook een taak met betrekking tot het op peil houden van de geschiktheid van de soldaat, officier, materieeldeskundige, VN-deskundige enz. of om er voor te zorgen dat personen in het krijgsmachtbedrijf kunnen voldoen aan functievereisten om hogerop te komen. Al deze aktiviteiten kosten geld, welke in rekening kunnen worden gebracht aan de afnemers. Dit hoeven niet alleen de produktie-eenheden of Defensiebedrijven te zijn, maar kunnen ook individuele personen zijn. Het aantal produkten dat het Defensieopleidingsinstituut-NV zal moeten verzorgen zall zeer aanzienlijk zijn. In hoofdstuk 6 hebben we reeds gezien dat opleidingen niet beperkt kunnen blijven tot strikt militaire, maar dat ook ruimte wrij gemaakt moet worden voor additionele burgeropleidingen en VN-opleidingen. Dit alles om te kunnen voldoen aan de taken van de diverse onderdelen van het krijgsmachtbedrijf, maar ook om de salariskosten te kunnen drukken.

Voor de burgeropleidingen en VN-opleidingen geldt dat de afnemers de aktiviteiten voor de opleidingen beperkt zullen proberen te houden tot die aktiviteiten die strikt noodzakelijk zijin voor de doelen die met de opleiding bereikt moeten worden. Het Defensieopleidingsinstituut-NV heeft ook hier geen vrije hand.

Uiteindelijk komt een militair in aktieve dienst bij een gevechtsonderdeel. Het gevechtsonderdeel is de plaats waar de personeelskant en de materieelkant duidelijk samenkomen. Gevechtsonderdelen hebben een geweldsmonopolie en dienen daarom rechtsstreeks onder de hiërarchie van de minister te vallen. Externe verzelfstandiging behoort hier dus niet tot de mogelijkheden. Een gevechtseenheid komt echter wel in aanmerking voor interne verzelfstandiging. Iedere gevechtseenheid krijgt een budget toegewezen wit de begroting. Met dit budget moeten zij voldoen aan de produktienormen welke voor dat onderdeel gesteld zijn in termen van oefendagen. Ook gevechtseenheden zullen trachten efficiënt met hun geld om te gaan, indien de efficiëntiewinst op enigerlei wijze gekoppeld is aan het persoonlijk inkomen van de leiding:

Gevechtseenheden komen in de produktieketen van het krifgsmachtbedrijf voor aan het einde van de produktieketen. Enkele bijzondere gevallen uitgezonderd kunnen zij geen prijzen in rekening brengen voor hun produkt. ${ }^{20}$ De gevechtseenheden krijgen hun inkomsten dan ook uit de Rijksbegroting. Met deze gelden kopen ze van het Defensieopleidingsinstituut-NV hun opgeleide soldaten, van de Defensiegebouwendienst-NV worden de gebouwer gehuurd enz.

Voor een overzichtelijke en efficiënte bedrijfsvoering is het noodzakelijk dat de gevechtseenheden niet te groot zijn. Bij de Landmacht kan gedacht worden aan een brigade als intern verzelfstandigde eenheid, bij de luchtmacht aan een wing en bij de Marine aan een taakgroep. Andere indelingen zijn ook mogelijk.

Voor het goed kunnen verlopen van de bedrijfswoering is het noodzakelijk dat de contacten met de toeleveranciers op een adequate wijze tot stand komen. Daar dit

\footnotetext{
20 Dilt komt natuurlijk door de goederenkarakteristieken wan het collectieve goed defensie. Zie oolk hoofdstuk 2 , paragraaf 1.
} 
werk voor de mulitaire top van een gevechtseenheid te belastend kan zijn, is het raadzaam de gevechtseenheden bij te laten staan door een bedrijfsbureau. Dit bedrijfsbureau is verantwoordelijk voor de financiêlle en logistieke administratie van een gevechtseentheid. Zij kan ook taken op zich nemen die logistiek het nivo van een gevechtseenheid overstijgen. ${ }^{21}$

De budgetten waar de toeleveranciers aan de gevechtseenheden uit kunnen putten zijn niet afkomstig wit de Rijksbegroting. Zij dienen hun geld geheel zelfstandig te verdienen en met de opbrengst van hun intermediaire produkt hun kosten te dekken. Zeker voor de toeleveranciers die grote concurrentie uit de burgermaatschappij kunnen verwachten is dit een wankele basis, doch indien ze goede kwaliteit leveren tegen een redelijke prijs is hun bestaan ook min of meer verzekerd.

De hier gepresenteerde decentrale opbouw van het krijgsmachtbedrijf laat een aantal taken die momenteel door de centrale organisatie worden uitgevoerd over aan de diverse Defensieinstituten en bedrijven. Voor de centrale organisatie van het Ministerie van Defensie blijven nog een aantal taken over, waarvan de besluitvorming ten aanzien van de te volgen strategie door de gevechtseenheden de belangrijkste is. Deel van deze strategie is het bewaren van een eenheid van beleid binnen de gevechtseenheden. Het kan natuurlijk nooit zo zijn dat de diverse gevechtseenheden verschillende soorten wapensystemen gebruiken.

Ook het in kaart brengen van de internationale veiligheidssituatie is een taak die overblifft voor de centrale organisatie. Van de financiële taken is de toewijzing van de budgetten aan de gevechtseenheden volgens normprijzen de belangrijkste taak. De toewijzing van budgetten aan opleidingen, materieel enz. vervalt omdat deze taak door het prijsmechanisme wordt overgenomen. Wel is het natuurlijk zo dat een deel van het financiële werk dat in het verleden door de centrale organisatie werd gedaan, nu gedaan wordt door de decentrale organisaties. Met betrekking tot de kwaliteitscontroles en plaatsen in de diverse Raden van Commissarissen is een plaats voor financiële experts van de centrale organisatie aan te raden, daar zij veelal in staat geacht kunnen worden de verschillende normprijzen en eventuele machtssituaties goed te doorgronden.

Van het personeelsbeleid blijft alleen het algemene personeelsbeleid in handen van de centralle organisatie. De exacte invulling van het personeelsbeleid komt te liggen bij de decentrale organisaties, waarbij iedere eenheid zijn eigen verantwoordelijkheid heeft ten aanzien van aan haar opgedragen taken. Dit betekent dat het Wervings- en Selectie-instituut-NV haar eigen beleid opstelt ten aanzien van werving en selectie, evenals het Defensieopleidingsinstituut-NV dat doet voor de opleidingen.

Indien we weer terugkeren naar de gevechtseenheden is het ook niet meer dan logisch dat een groot aantal aktiviteiten daar geregeld en verantwoord worden, omdat voor het leveren van maatwerk de situatie ter plekke de beste uitkomsten oplevert. Moet het contract van een soldaat verlengd worden? Wat is de ideale lengte van een contract gezien de capaciteiten, mogelijkheden en kosten die aan een specifieke soldaat verbonden zitten? Willen we daadwerkelijk komen tot een efficiènte krijgsmacht dan is maatwerk een vereiste, waarbij maatwerk verkregen kan worden door privatisering. Privatisering zorgt er voor dat de krijgsmacht wordt opgesplitst in een groot aantal "bedrijfjes" die ieder hun prikkels hebben gekregen om zo efficiënt mogelijk te

\footnotetext{
21 Dararvoar zal zij wel vergoed moeten worden door de gebruikers. Als voorbeeld kan gedacht worden aan de mogelijkheid dat het bedriffsoureat van cén gevechtseenheid de onderhandelingen woert met een vervoersmaatschappij over gen goede busverbinding van en naar de kazerne, waar ook de andere gevechtseenheden die aanwezig zijn op de kazeme van profitteren. De kosten van die onderhancielingen zullen dan ook naar rato moeten worden doomorekend wan de afnemers.
} 
handelen. Niet ieder krijgsmachtbedrijfe zal in dezelfde mate gebruik willen of kunnen maken van deze prikkels, maar de aanzet tot efficiënt handelen is in principe aanwezig. Dit zal de maatschappelijke aanvaarding van de krijgsmacht aanzienlijk verbeteren, zowel in algemene als in specifieke zin.

Prikkels zijn aanwezig om de kansarmen in de maatschappij ook een kans te geven in de krijgsmacht, prikkels zijn aanwezig om vrijwilligers er voor te behoeden dat zij aktiviteiten moeten verrichten die niet functioneel zijn, prikkels zijn aanwezig om militairen te vervangen door burgers omdat burgers nu eenmaal minder kosten met zich mee brengen. Prikkels zorgen voor een toegenomen dynamiek en toegenomen dynamiek is niets anders dan een betere wisselwerking tussen twee fenomenen, in dit geval de krijgsmacht en de maatschappij.

Privatisering van de krijgsmacht laat de diverse onderdelen van de krijgsmacht zien welke kosten verbonden zijn aan hun handelen. Door privatisering wordt hun duidelijk gemaakt dat zij omgaan met schaarse middelen, welke grote waarde hebben in de maatschappij. Privatisering van de krijgsmacht vermindert het "free-rider" gedrag van de diverse onderdelen, omdat zij nu zelf voor de kosten van het gebruik dienen op te draaien en niet een ander onderdeel van de krijgsmacht, zoals in een situatie zonder privatisering vaak het geval is.

Het is juist het "free-rider" gedrag van bepaalde eenheden dat gevaren voor de maatschappij kan meebrengen. Hoewel door de privatisering de gevaren van bijvoorbeeld een staatsgreep niet uit te sluiten zijn, kan zij wel aan velen het gevoel meegeven, dat aan zo'n actie grote maatschappelijke kosten verbonden zijn, die uiteindelijk op het bord kunnen komen van de eenheid die de actie zelf ondernomen heeft. Bovendien zijn de gevechtseenheden in grote mate afhankelijk van overheids-NV's. Willen zij maatschappij onvriendelijke aktiviteiten uitvoeren dan dienen zij toch zeker een groot aantal van deze bedrijven achter zich te hebben.

Voordat we deze paragaaf afronden met een aantal schema's van de overgebleven kerntaken van de krijgsmacht, rest ons nog de levenscysclus van de militair af te ronden. Na zijn aktieve dienst bij een gevechtseenheid zal hij deze verlaten. Indien hij gepensioneerd wordt zal hij verder niet meer direct in aanraking komen met de krijgsmacht. Zijn pensioen krijgt hij van een pensioenfonds en daarmee is de kous af. Indien de militair de gevechtseenheid verlaat om in de burgermaatschappij te gaan werken, kan hij vaak veel plezier hebben aan enige hulp bij zoeken naar een nieuwe baan. In dit geval dient de krijgsmacht op enigerlei wijze zorg te dragen voor het produkt "overgang naar de burgermaatschappij". Bij de burgermaatschappij hoeft niet strikt gedacht te worden aan een baan buiten het krijgsmachtbedrijf om. Het kan best zo zijn dat deze militair een baan vindt in één van de andere Defensiebedrijven. Daar bij een militair de kosten van het specifieke produkt "overgang naar de burgermaatschappij' kunnen worden toegeschreven aan een gevechtseenheid vallen de kosten ook in deze toe aan deze gevechtseenheid.

De kerntaken van het krijgsmachtbedrijf worden uitgeoefend door de gevechtseenheden. Welke taken dit zijn krijgt zij opgedragen door het Ministerie van Defensie. Het Ministerie onderzoekt de vraag naar veiligheid op de internationale veiligheidsmarkt, de krijgsmacht levert het aanbod (zie schema 7.2). In dit schema is uitgegaan van het loslaten van de huidige structuur van het Ministerie van Defensie waarin een onderscheid wordt gemaakt tussen Landmacht, Luchtmacht en Marine. 


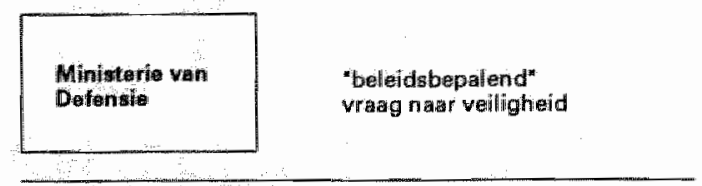

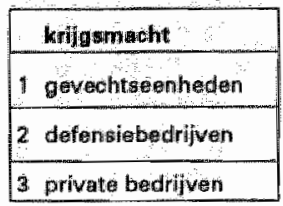

"beleidisustwoerend"

a anbod van veiligheid

sohema 7.2 Wraag en aanbod $n$ aar veiligheid

De gevechtseenheden maken gebruik van inputs aan de personele en aan de materiële kant. De gevechtseenheden staan dan ook centraal in het krijgsmachtbedrijf. Dit komt tot uitdrukking in schema 7.3. In schema 7.3 zijn slechts de besproken directe toeleveranciers aan de gevechtseenheden opgenomen. De catering, geneeskundige, psychologische en maatschappelijke diensten zijn in de praktijk wel degelijk aanwezig, doch zijn hier ten behoeve van de overzichtelijkheid van het verhaal en het schema weggelaten.

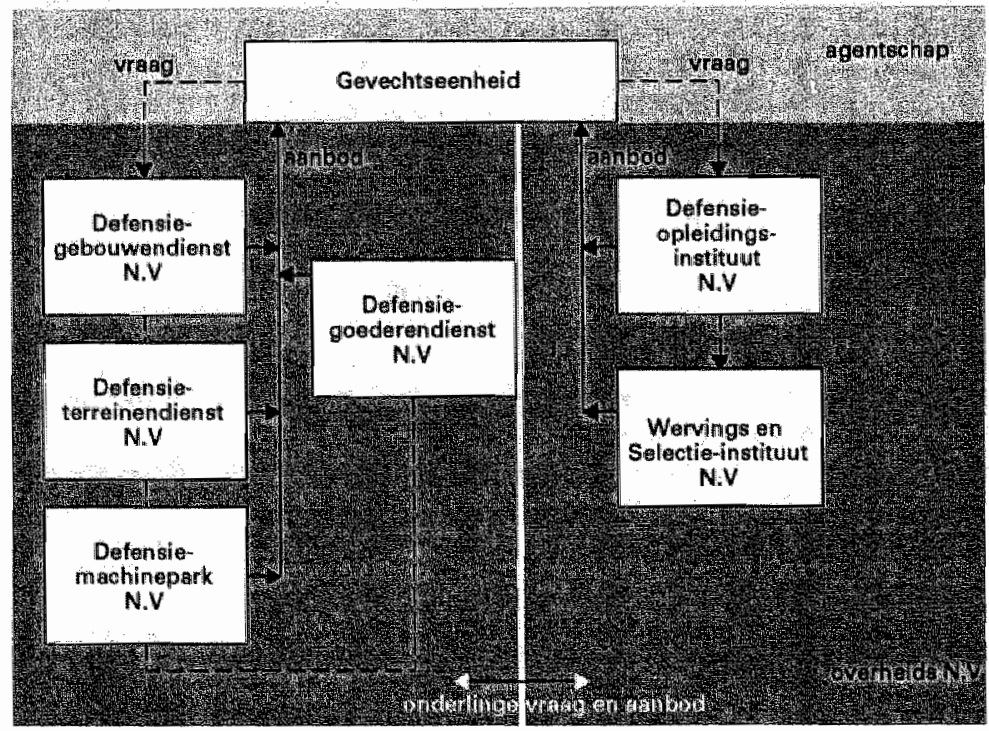

schema 7.3 Het verband tussen de gevechtseenheden en de defersiebedrijven 
Tenslotte hebben we onder de diverse externe verzelfstandigde bedrijven een groot aantal particuliere ondernemingen die in het gevechtskrachtproduktieproces ook een rol spelen. Schema 7.4. is dan ook het laatste schema in de rij van het privatiseringsproces, welke in schema 7.2. voerde van Ministerie naar agentschap, in schema 7.3. van agentschap naar Overheids-NV en in schema 7.4. van Overheids-NV naar particuliere vennootschap of onderneming.

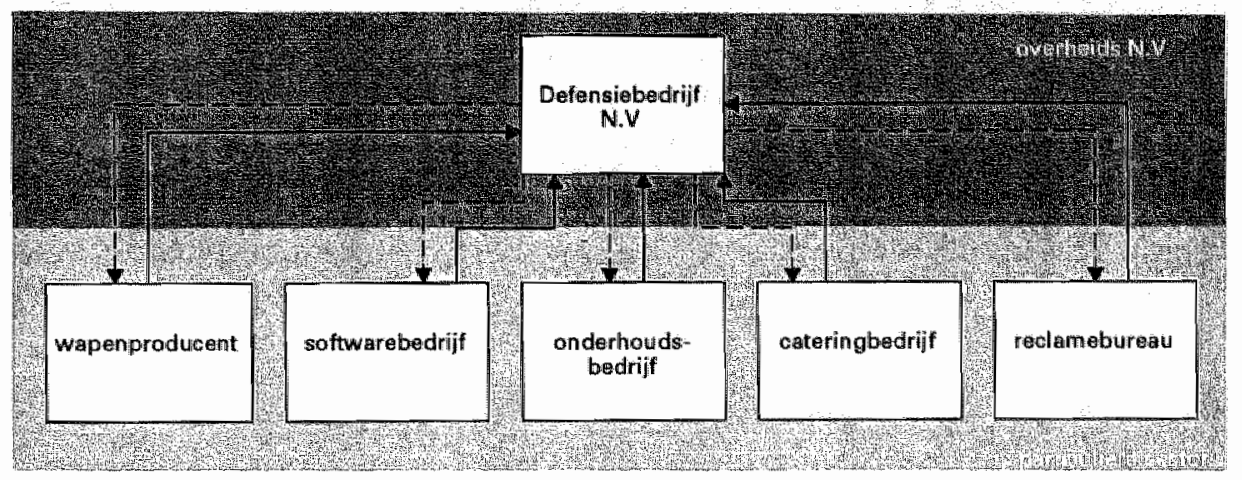

schema 7.4 Het verband tussen de overheids.N.W en de particuliere onderneminng

\section{$\$ 7.3$. Conclusies}

In dit hoofdstuk heeft de wisselwerking tussen maatschappij en krijgsmacht centraal gestaan. De wisselwerking tussen maatschappij en krijgsmacht is vanuit een economische wijze benaderd. Zij heeft zich gericht op de interne dynamiek van de krijgsmacht en heeft gezocht naar die instrumenten die er voor kunnen zorgen dat de krijgsmacht geruisloos bij de maatschappij aansluit, ook in de afwezigheid van de dienstplicht. Wisselwerking tussen twee fenomenen is een vraag naar de dynamiek tussen beide fenomenen. Uit de economische literatuur komt naar voren dat dynamiek een vraagstuk van prikkels is. Daar waar prikkels ontbreken, zal de dynamiek op den duur verloren gaan.

De wisselwerking tussen maatschappij en krijgsmacht is dan ook een zoektocht naar prikkels die deze wisselwerking ten goede kunnen zijn. Deze prikkels kunnen onder meer worden gevonden door ondergeschikten de mogelijkheid te geven onafhankelijk van hun meerderen te kunnen opereren. Aan ondergeschikten moeten de mogelijkheden open staan hun meerderen te kunnen weerstaan zonder dat dit repercussies voor de ondergeschikten kan opleveren. Voorbeelden hiervan zijn de bevordering op basis van objectieve maatstaven en de mogelijkheid op elk gewenst moment ontslag te nemen.

Privatisering is een andere mogelijkheid om de dynamiek van de krijgsmacht te verbeteren. Privatisering brengt niet alleen een betere wisselwerking tussen maatschappij en krijgsmacht, maar bovendien kan privatisering de prikkels geven tot besparingen op de Defensiebegroting. Maatschappelijk baten gaan hand in hand met budgettaire baten. 
In dit hoofdstuk is weergegeven hoe privatisering van de krijgsmacht in vredestijd gestalte kan krijgen. Bovendien is de beschreven organisatiestructuur zeer geschikt in een oorlogssituatie, waarbij echter de opmerking gemaakt dient te worden dat in een oorlogssituatie de effectiviteit voorop staat en het efficiëntie-aspect tijdelijk naar de achtergrond verdwijnt. Overigens geldt het achterwege laten van de efficiëntieaspecten alleen voor die oorlogssituaties die direct bedreigend zijn voor de soevereiniteit van de eigen samenleving.

Hebben we te maken met het uitvoeren van $\mathrm{VN}$-taken, dan is de toewijzing van extra budget de geëigende weg om de taken in VN-verband uit te voeren, waarbij wel degelijk de efficiëntieregels in het achterhoofd een rol moeten spelen.

Of privatisering van Defensie in de praktijk daadwerkelijk uitvoerbaar is, is een vraag van een hele andere orde. Privatisering is wel degelijk technisch mogelijk, de cultuur van de krijgsmacht is echter een punt waar terdege rekening mee moet worden gehouden. Vele privatiseringsprocessen zijn mislukt, omdat de cultuur van het te privatiseren bedrijf zich niet verdroeg met de noodzakelijk te nemen stappen. In het volgende hoofdstuk, dat handelt over de overgang van een dienstplichtigenleger naar een vrijwilligersleger, zullen we op dit punt nader ingaan. 


\section{De overgang van een dienstplichtigen- leger naar een vrijwilligersleger}

"Under the volunteer army, there is no reason why we couldn't maintain a "stand-by" draft - a reserve mechanism to be called upon only in case of national emergency."

James C. Miller, A volunteer army for America, In: Miller J. (ed.), Why the Draft, the Case for the Volunteer Force, Baltimore, 1968, blz. 185.

De grondwet, artikel 97 , bepaalt dat:

"Alle Nederlanders daartoe in staat, zijn verplicht mede te werken tot handhaving van de onafhankelijkheid van het Rijk en tot verdediging van zijn grondgebied".

"Tot bescherming van de belangen van de staat is een krijgsmacht, bestaande tuit vrijwillig dienenden en ulit dienstplichtigen",

vervolgt de grondwet in artikel 98 . Uit deze formulering kan worden gelezen dat de krijgsmacht altijd dienstplichtigen in haar midden dient te hebben, en dat met andere woorden een vrijwilligersleger grondwettelijk onmogelijk is. Artikel 98, lid 1 van de grondwet stamt uit 1887 en had tot strekking de dienstplicht eindelijk eens een grondwettelijke basis te verschaffen. Echter het was geenszins de bedoeling om de wetgever te verplichten de krijgsmacht mede uit dienstplichtigen te recruteren als daar technisch de noodzaak niet toe bestond. ${ }^{1}$ Dit betekent dat er geen juridische belemmeringen bestaan om een dienstplichtigenleger in Nederland om te zetten in een vrijwilligersleger. Omgekeerd geldt natuurlijk hetzelfde.

Desondanks heeft de Raad van State gemeend dat de afschaffing van de dienstplicht niet zonder wijziging van de grondwet kan. Zij komt tot deze conclusie op basis van de stelling dat in de grondwet het woord "dienstplichtigen" voortkomt, en dat de krijgsmacht grondwettelijk gezien niet zonder dienstplichtigen kan. Willen we de dienstplicht afschaffen dan dient volgens de Raad van State de grondwet gewijzigd te worden. Toch kunnen er een aantal opmerkingen worden geplaatst bij de stelling name van de Raad van State.

De dienstplicht is een instituut, welke uit een aantal onderdelen bestaat. Het eerste onderdeel bestaat uit de registratie van de dienstplichtige, vervolgens wordt de dienstplichtige gekeurd, alvorens de dienstplichtige verplicht is op te komen voor de

II Zie N.H.M. Roos, NRC-Handelsblad, 3 november 1992, opiniepaginia. 
eerste oefening. $\mathrm{Na}$ de eerste oefening moet een dienstplichtige nog een aantal malen op herhalingsoefening. Bij het afschaffen van de dienstplicht gaat het hoofdzakelijk om het afschaffen van de opkomstplicht yoor de eerste oefening en de herhalingsoefeningen. De registratieplicht en de keuringsplicht kunnen altijd blijven bestaan en maken ook in een vrijwilligersleger deel wit van het personeelssysteem van de krijgsmacht. De dienstplichtigen zijn op deze wijze op afstand geplaatst van de krijgsmacht, maar maken nog wel degelijk deel uit van het instituut krijgsmacht. Indien het begrip "dienstplichtigen" op deze wijze wordt geinterpreteerd is een wijziging van de grondwet in zijn geheel niet nodig. Dienstplichtigen maken nog wel degelijk deel uit van de krijgsmacht, al zijn zij niet direct fysiek aanwezig. Blijkbaar is de Raad van State een andere mening toegedaan.

Dit hoofdstuk zal zich bezig houden met het conversievraagstuk dat samenhangt met de overgang van een dienstplichtigenleger naar een vrijwilligersleger. Daartoe zal allereerst worden gekeken naar het moment waarop een dienstplichtigenleger kan worden omgezet in een vrijwilligersleger. Belangrijk is dat voor deze overgang een voldoende politiek draagvlak is. De vraag hierbij is in hoeverre de diverse welvaartsposities van individuen in onze samenleving beïnloedt worden door de overgang van een dienstplichtigenleger naar een vrijwilligersleger. In paragraaf 1.5 . hebben we de welvaartsposities van vier groepen centraal gesteld. Indien we de analyses in de hoofdstukken hiervoor in beschouwing nemen, zien we dat met de overgang van een dienstplichtigenleger naar een vrijwilligersleger, de welvaartspositie van de dienstplichtigen verbetert (hoofdstuk 4). Ook de positie van de algemene belastingbetaler gaat er op vooruit, ondat in een vrijwilligersleger de 'excess burden' van de dienstplichtbelasting wegvalt (hoofdstuk 5). Bovendien wordt de krijgsmacht door het afschaffen van de dienstplicht geconfronteerd met de werkelijke kosten van dienstplichtigen en met echte schaarste aan arbeidskrachten. Dit leidt er toe dat de binding tussen maatschappij en krijgsmacht eerder versterkt wordt dan verzwakt ten opzichte van de situatie in een dienstplichtigenleger (hoofdstuk 7 ) en bovendien tot een kwalitatief betere krijgsmacht, omdat door het omgaan met echt schaarse arbeidskrachten de krijgsmacht gedwongen wordt zijn personeel serieus te nemen. Doet zij dit niet dan snijdt zij zich met een hoop taken zelf in de vingers (hoofdstuk 6). De welvaartsposities van alle vier de groepen verbeteren op de lange termijn. Met andere woorden, hier is sprake van een duidelijke Pareto-verbetering die er zorgt dat het ook in politiek opzicht mogelijk is over te stappen van een dienstplichtigenleger naar een vrijwilligersleger.

Vervolgens zal in dit hoofdstuk worden ingegaan op de instrumenten die in het conversieproces gebruikt kunnen worden, teneinde de overgang een succes te maken. Ook zal aandacht worden besteed an de omschakeling van een centraal geleide organisatle naar een decentralle organisatie, zoals is beschreven in hoofdstuk 7. Daarnaast zullen de consequenties voor de mobilisabele eenheden bekeken worden. Tenslotte zal worden ingegaan op de cultuurverandering die de krijgsmacht zal moeten ondergaan, wil zil het conversieproces tot een goed einde willen brengen. De erfenis van de dienstplicht kan niet te lang blijven hangen, wil het vrijwilligersleger effectief en efficieint kunnen handelen.

\section{\$8.1. De keuze tussen een dienstplichtigenleger en een vrijwilligersleger}

Iedere samenleving zal zich proberen te verdedigen tegen indringers van buitenaf. Indien een keuze gemaakt zal moeten worden hoe deze verdediging in te vullen, zal 
al snel de vraag worden gesteld of een dienstplichtigenleger of een vrijwilligersleger nodig is. Deze vraag is echter moeilijker te beantwoorden dan op het eerste gezicht lijkt.

Zoals blijkt uit de hoofdstukken 4 en 5 van dit proefschrift, is in deze tijd een vrijwilligersleger te prefereren boven een dienstplichtigenleger, omdat de kosten van een vrijwilligersleger in vredestijd altijd lager zijn dan de kosten van een dienstplichtigenleger. Bovendien hebben we in de hoofdstukken 6 en 7 gezien dat er ook op andere terreinen, zoals de kwaliteit van de krijgsmacht en de binding tussen maatschappij en krijgsmacht geen problemen te verwachten zijn, mits de juiste instrumenten worden gebruikt.

Een vrijwilligersleger is efficiënt in haar gebruik van produktiefactoren. Zij doorkruist de vrije keuze tussen arbeid en kapitaal niet, waardoor de relatieve prijzen van de produktiefactoren niet worden verstoord en er geen "excess burden" optreedt. De vulling van een vrijwilligersleger komt tot stand door middel van zelfselectie en sluit daarom uit dat de "opportunity costs" van de vrijwilligers hoger zijn dan het gangbare loon in de krijgsmacht. Dienstplicht kent het systeem van zelfselectie niet, waardoor de "opportunity costs" altijd hoger zijn dan de loonkosten. In het gebruikte kostenconcept zijn de "opportunity costs" altijd de centrale schakel geweest. Deze "opportunity costs" spelen dan ook een cruciale rol in de keuze tussen een dienstplichtigenleger en een vrijwilligersleger, zeker indien we beseffen dat een keuze voor een dienstplichtigenleger zeker opportuun kan zijn.

Naast de kosten wordt ook aan de flexibiliteit grote waarde gehecht in de keuze tussen een dienstplichtigenleger en een vrijwilligersleger. De keuze tussen de beide mogelijkheden kan namelijk niet voortdurend worden veranderd. Een eenmaal gemaakte keuze zal enige tijd mee moeten gaan. Van een vrijwilligersleger wordt gezegd dat dit duur en inflexibel is. Met betrekking tot de kosten hebben de vorige hoofdstukken al voldoende gezegd. Budgettair gezien kan een vrijwilligersleger duur lijken. Dit zal zich zeker voordoen in tijden van militaire expansie. Maatschappelijk is dit echter niet zo, en ook budgettair kunnen de kosten zeer goed in dle hand worden gehouden. Bij een uitbreiding van de krijgsmacht dient de krijgsmacht een hoger deel van het arbeidsaanbod aan te trekken, wat in termen van "economic rent" kostbaar kan zijn. Doch het gebruik van tijdelijke bonussen kan er voor zorgen dat de "economic rent" binnen de perken blijft. Flexibiliteit in een vrijwilligersleger kan ook worden verkregen met behulp van bonussen, om op deze wijze vraag en aanbod op een snelle wijze in overeenstemming met elkaar te brengen zonder de normale salarisstructuur te hoeven verstoren.

De voordelen van dienstplicht zijn voornamelijk gelegen in de grotere mate van flexibiliteit en zekerheid. Daarnaast levert dienstplicht financiële voordelen op voor de krijgsmacht in oorlogstijd. In vredestijd spelen deze financiële voordelen een ondergeschikte rol, omdat ze in het riet vallen tegen de maatschappelijke kosten. In oorlogstijd kan dit anders zijn, omdat bij volledige mobilisatie het complete nationale vermogen in gevaar is. Gedurende zulke perioden kan de sociale waarde van produktiefactoren haar marktwaarde overschrijden, waardoor het instellen van de dienstplicht opportum is. De directe bescherming van de maatschappij levert in dit geval grote maatschappelijke baten op, welke zonder dienstplicht nooit verkregen zouden kunnen worden.

In termen van "opportunity costs" laat de keuze tussen een dienstplichtigenleger en een vrijwilligersleger zich vertalen naar de vraag wanneer de "opportunity costs" voor de maatschappij in termen van oorlogsschade aan mensen en kapitallgoederenvoorraad groter zijn dan de "opportunity costs" voor de soldaten. 
Daarbij dienen we ons voor ogen te houden dat de schade aan de mensen en kapitaalgoederenvoorraad nul is bij vrede, gering zal zijn bij een beperkte actie en zeer groot zal zijn bij een invasie.

De "opportunity costs" voor de soldaten zullen bij een dienstplichtigenleger altijd groter zijn dan bij een vrijwilligersleger, maar de schade aan de mensen en de kapitaalgoederenvoorraad zal groter zijp bij een vrijwilligersleger dan bij een dienstplichtigenleger. Algebraïsch zal voor de "opportunity costs" van de soldaten in een dienstplichtigenleger ( $O C D s$ ) een relatie kunnen gelden van:

$$
O C D s=a_{1}+b_{1} X \quad(0<X<1)
$$

waarbij $X$ een maatstaf voor veiligheid is, die zich vertaalt in het aantal soldaten dat nodig is. Indien $X=0$ dan is de situatie zeer veilig en indien $X=1$ is er sprake van een invasie.

De schade aan de mensen en de kapitaalgoederenvoorraad bij een dienstplichtigenleger $(O C D m)$ kan worden weergegeven door de volgende vergelijking:

$$
O C D m=\left(d_{1} e^{x}\right) /(1-X)
$$

Bij een relatief veilige situatie $(X=0)$ is er $d 1$ schade en in een situatie waarbij $X=1$ is de schade oneindig groot.

De totale kosten bij een dienstplichtigenleger $(O C D)$ zijn nu:

$$
O C D=O C D s+O C D m
$$

Voor een vrijwilligersleger geldt een zelfde soort relatie:

$$
\text { OCVs }=a_{2}+b_{2} X \quad(0<X<1)
$$

en

$$
O C V m=\left(d_{2} e^{x} /(1-X)\right.
$$

waarbij $a_{2}<a_{1}, b_{2}<b_{1}$ en $d_{2}>d_{1}$. De totale kosten zijn hier:

$$
O C V=O C V s+O C V m
$$

Grafisch laten de vergelijkingen 8.3. en 8.6. zich weergeven als in figuur 8.1, waarbij de stippellijn de kosten bij een dienstplichtigenleger en de ononderbroken lijn de kosten bij een vrijwilligersleger uitbeelden. Duidelijk is dat het overgangspunt daar moet liggen waar de schade aan de mensen en de kapitaalgoederenvoorraad duidelijk wordt en niet meer tegengegaan kan worden door het aantrekken van vrijwilligers met welke prikkels dan ook. Het is echter zeer moeilijk om het echte overgangspunt aan te geven. Dit overgangspunt hangt samen met de mogelijkheden van een invasie. 


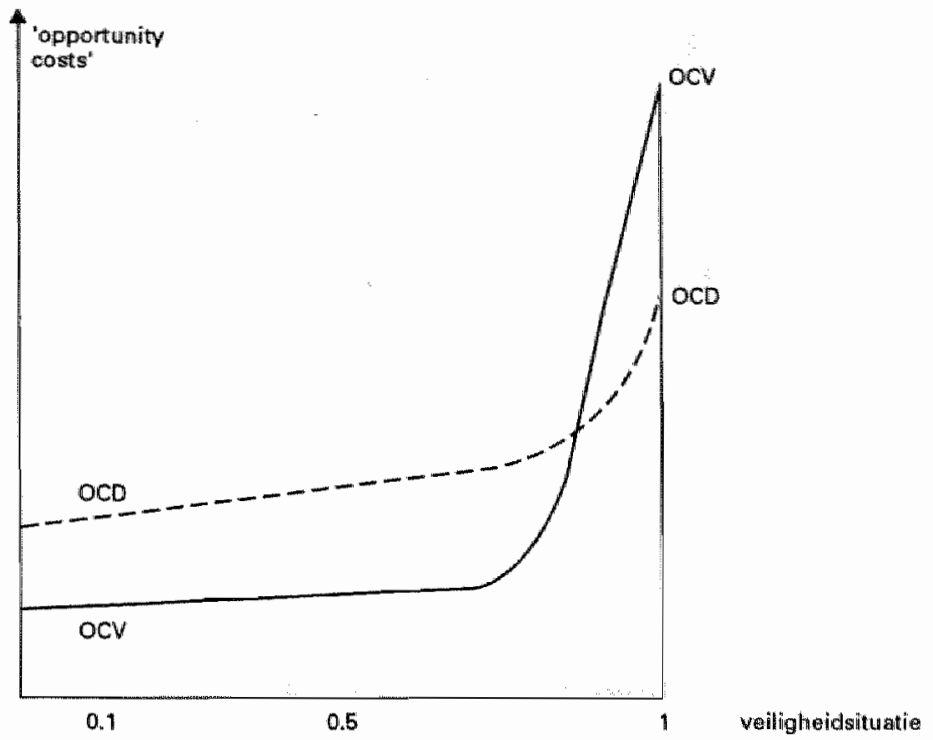

figuur 8.1 De kasten van een vrijwilligersleger en een dienstplichtigenleger

Bij een invasie zijn de kosten het hoogst, en zou dus eigenlijk dienstplicht moeten gelden, doch als de dienstplicht wordt ingevoerd op het moment van de invasie kan het al te laat zijn. Gezien de huidige technische mogelijkheden om een verrassingaanval te zien aankomen, zal een invasie niet onverwacht komen en bovendien is de gevechtskracht om een invasie tegen te houden in grote mate afhankelijk van het beschikbare materieel. Indien het gevechtsmaterieel op is, begint een soldaat weinig. Er zal hoogstens plaats zijn voor het gebruik van handwapens en het dragen van een uniform. Schieten kan iedereen in zeer korte tijd leren en de praktijk van de oorlog maakt mensen al snel geoefend in het hanteren van een handwapen. Dienstplicht is dus niet direct noodzakelijk bij een invasie. Op basis van vrijwilligheid is zeer veel te bereiken, daar in onze wereld bovendien geldt dat de hoeveelheid mensen en de snelheid waarmee mensen ingezet kunnen worden in een krijgsmacht niets zegt over de gevechtskracht van deze krijgsmacht. Gevechtskracht is een combinatie van kapitaal en arbeid, waarbij beide componenten gewicht in de schaal leggen.

Daar we in deze maatschappelijke kosten-batenanalyse slechts in termen van onzekerheid ktunnen spreken over de kosten van een vrijwilligersleger of een dienstplichtigenleger is een gevoeligheidsanalyse op basis van deze analyse niet mogelijk. Zoals Frank $\mathbb{H}$. Knight ons duidelijk heeft gemaakt in zijn "Risk, uncertainty and profit" kurnen gevoeligheidsanalyses pas worden uitgevoerd, indien de specifieke kansen op bepaalde gebeurtenissen bekend zijn. De internationale veiligheidssituatie kent deze kansen helaas niet.

Concluderend kunnen we aan het einde van deze paragraaf stellen dat de keuze tussen een dienstplichtigenleger en een vrijwilligersleger slechts dan ten gunste van een dienstplichtigenleger vitvalt, indien dle vrijheid en de veiligheid van de gemeen- 
schap in groot gevaar verkeren en een invasie niet meer gestopt kan worden door de reguliere krijgsmacht met behulp van hun gevechtsmaterieel en beroepsmilitairen.2

Voor de dienstplicht als formele regeling betekent dit niet dat de dienstplicht ook wit de grondwet dient te verdwijnen, indien er geen dienstplichtigenleger is. In een vrijwilligersleger blijft de dienstplicht wel bestaan, alleen worden er geen dienstplichtigen opgeroepen. De opkomstplicht vervalt in dit geval. In een vrijwilligersleger kunnen de registratie en de keuring van potentiêle dienstplichtigen blijven bestaan. De registratie en keuring van dienstplichtigen zorgen er voor dat de krijgsmacht altijd terug kan vallen op dienstplichtigen. Zij zijn in feite op afroep beschikbaar en maken direct onderdeel uit van de krijgsmacht. De keuze tussen een dienstplichtigenleger en een vrijwilligersleger betekent praktisch dan aok de keuze tussen de opkomstplicht en het laten vervallen van de opkomstplicht. Een keuze welke staatsrechtelijk zonder veel problemen kan worden gemaakt.

\section{\$ 8.2. De overgang van een dienstplichtigenleger naar een vrijwilligersleger}

Uit het voorgaande blijkt dat de aantrekkelijkheid van een vrijwilligersleger groot is en indien we momenteel reeds zo"n krijgsmacht zouden hebben, zou het heel wat waard zijn om deze te behouden. Toch zal het nog een aanzienlijke klus zijn het dienstplichtigenleger in te ruilen voor een vrijwilligersleger, amdat de overgang van eén systeem naar een ander systeem met grote kosten gepaard kan gaan. Voor de overgang naar een vrijwilligersleger zijn een aantal aanpassingen noodzakelijk. Deze aanpassingen hebben te maken met de overgang van een centraal geleid systeem, dat een dienstplichtigenleger in feite is, naar een vrijwilligersleger dat een marktconform systeem omhelst. Aanpassingen die te maken hebben met een verandering van de hoeveelheid te produceren gevechtskracht ${ }^{3}$ zullen hier niet expliciet behandeld worden. Voor het overgrote deel kunnen deze aanpassingen worden ondergebracht bij de aanpassingen die nodig zijn voor de overgang naar een vrijwilligersleger. Alleen zal de dimensie van de aanpassingen een stuk groter zijn, dan in het geval dat de hoeveelheid te produceren gevechtskracht dezelfde was gebleven.

De eerste stap welke nodig is voor het opzetten van een vrijwilligersleger is dat de wedde van dienstplichtigen wordt opgetrokken naar het niveau van beroepsmilitairen. Deze weddeverhoging heeft drie dimensies. Allereerst heeft een hogere zichtbare wedde effect op de aantrekkelijkheid van het soldatenbestaan. Door een hogere wedde zal het aanbod van vrijwilligers toenemen, al was het alleen maar omdat de huidige dienstplichtigen een positievere kijk krijgen op hun eigen werk. Zij worden naar de waarde van hun arbeid betaald, waardoor hun arbeid ook meer aanzien krijggt.

De tweede dimensle van een weddeverhoging is dat het gebruik van dienstplichtigen kostbaarder wordt. Door het feit dat de werkelijke kosten van militaire arbeid zichtbaar worden, zal een proces op gang moeten kunnen komen, welke er voor zorgt dat substitutie van militaire arbeid door kapitaal en burgerarbeid plaatsvindt. In hoofdstuk 5 hebben we kunnen zien dat dit proces tot aanzienlijke kostenbesparingen kan leiden, mits de dienstplichtige niet alleen als een dure produktiefactor wordt gezien, maar bovendien als een schaarse produktiefactor. Een weddeverthoging ver-

\footnotetext{
2 Zie ook ]. van Puttan, "Geen reden te sterven voor de staat", NRC-Handelsblad, 31-10-1992, opiniepagina.

${ }^{3}$ De verandering van de hooveelheid gevechtskracht is voortgekomen uit de gewijzigde veiligheidssituatie waarover de Prioriteitennota 1993 bericht. In principe wordt hier dus uitgegaan wan de gevechtskracht die nodig is volgens de Defensienota 1991, orndat er systematisch niets verandert.
} 
schaft ons hier de noodzakelijke prikkels voor het substitutieproces, maar is nog niet een voldoende prikkel.

Een derde dimensie van de weddeverhoging is de compensatie van dienstplichtigen voor hun verlies aan inkomen, gedurende hun diensttijd. De weddeverhoging zal nooit volledig compenserend kunnen zijn, omdat niet ieders "opportunity costs" gelijk zijn. Bovendien zal de weddeverhoging naar het niveau van beroepsmilitairen naar alle waarschijnlijkheid geen compensatie kunnen bieden voor zaken als de "baalpremie" en het verlies aan inkomen nadat de dienstplichtperiode is afgesloten. Toch zal de compensatie ook haar effect hebben ten aanzien van het ontwijken van de dienstplichtbelasting. Door de compensatie vermindert de last aanzlenlijk, waardoor het ontwijkingsgedrag ook zal verminderen. Dit zal zeker gelden voor jongens, waarbij de feitelijke compensatie ook de "baalpremie" dekt.

Een weddeverhoging naar het niveau van beroepsmilitairen kost geld, maar zorgt ook voor de nodige prikkels om een vrijwilligersleger te kunnen opstarten. Hoeveel geld gemoeid is met de weddeverhoging is afhankelijk van de tijdsduur van de overgang naar een vrijwilligersleger. Enerzijds is er een prijseffect dat er voor zorgt dat de wedde van dienstplichtigen een groter deel van de begroting van het Ministerie van Defensie voor zijn rekening neemt. Anderzijds is er een volume-effect, omdat door de weddeverhoging het aantal dienstplichtigen zal afnemen. Het totaal effect van de weddeverhoging is onduidelijk. Veell zal afhangen van de snelheid waarmee het aantal dienstplichtigen afneemt. Vlak na de invoering van een hogere wedde zall er sprake zijn van hogere kosten, maar of deze situatie weken, maanden of jaren gaat duren hangt samen met de effectiviteit van het reorganisatieproces.

Een weddeverhoging naar beroepsniveau kan binnen enkele dagen geregeld zijn, het laten verdwijnen van de dienstplichtigen hangt samen met de mate waarin burgers en vrijwilligers kunnen worden geworven om deze taken over te nemen. De produktie in het krijgsmachtbedrijf dient immers voort te gaan, anders is zij niet inzetbaar.

Het afschaffingstraject dient te beginnen met een analyse van de hoeveelheid eenheden die daadwerkelijk nog nodig zijn om de gestelde gevechtskracht te kunnen produceren. Dienstplichtigen die op functies zitten die niet meer nodig zijn, kunnen het best direct naar huis worden gestuurd, omdat zij slechts nutteloze bijdragen leveren. De dienstplichtigen die niet-gevechtsfuncties vervullen, dienen vervangen te worden door burgerpersoneel. De inhuur van uitzendkrachten kan daarbij voor een soepele overgang zorgen; omdat de dienstplichtigen op niet-gevechtsfuncties functies vervullen die slechts weinig specialistische kennis vereisen. Chauffeur, kopieerhulp of hofmeester zijn de meest sprekende voorbeelden in deze.

De dienstplichtigen die nuttige gevechtsfuncties vervullen zullen het langst moeten dienen. Voordat die dienstplichtigen naar huis kunnen, moeten eerst vrijwillige soldaten geworven en opgeleid worden. Dit kost enige tijd, maar kan toch binnen anderhalf jaar na het besluit om over te gaan nar een vrijwilligersleger te bewerkstelligen zijn.

Door de overgang van een dienstplichtigenleger naar een vrijwilligersleger zullen niet alleen dienstplichtigen verd wijnen, maar zullen tevens functies voor beroepsmilitairen gaan verdwijnen. Ten einde ontslag te vermijden zullen voor de beroepsmilitairen op deze functies oplossingen moeten worden gevonden.

Een eerste oplossing is dat een a antal beroepsmilitairen de functies van soldaten gaat overnemen. Op het eerste gezicht lijkt dit een degradatie, doch nader beschouwd kan dit nogal meevallen. Dit komt omdat de functie van soldaat in het toekomstige vrijwilligersleger heel anders zal zijn dan de functie van soldaat in het vroegere 
dienstplichtigenleger. Enerzijds speelt hier dat de krijgsmacht nieuwe taken heeft gekregen die inhoudelijk veel meer vragen van een soldaat, anderzijds zal door de toepassing van het subsidiariteitbeginsel binnen de krijgsmacht, de soldaat voor de meeste zaken zelf verantwoordelijk zijn. Daarmee komt de functie van soldat in het toekomstige vrijwilligersleger meer overeen met de functie van een onderofficier in het vroegere dienstplichtigenleger. Groot verschil is dat de toezichthoudende functies. vrijwel verdwenen zijn, daar de toezichthouders in de gevechtseenheden nu zelf het werk verrichten. Een bijkomend voordeel van de toepassing van het subsidiariteitsbeginsel is dat dit beginsel kan bijdragen aan een verbetering van het reconstitutievermogen van de krijgsmacht. Mocht de internationale veiligheidssituatie zo zijn dat terug moet worden gegaan naar de instelling van een dienstplichtigenleger, dan kunnen soldaten in het vrijwilligersleger worden doorgeschoven naar leidinggevende functies in een dienstplichtigenleger.

Het subsidiariteitsbeginsel zal voor velen binnen de krijgsmacht een ware cultuurschok kurnen veroorzaken, doch indien de spelregels van de subsidiariteit en de inhoud van de nieuwe soldatenfunctie goed worden tuitgelegd en uitgevoerd, kan hier zonder veel problemen op een praktische wijze worden uitgekomen. Wel zal het zo kunnen zijn dat door de verandering van functie van soldaat of door een verandering van het onderdeel, de vroegere onderofficier opnieuw een opleidingsfase zal moeten doorlopen om ingespeeld te raken op zijn toekomstige taak.

Het inzetten van vroegere onderofficieren op toekomstige soldatenfuncties hoeft niet samen te gaan met een verandering van rang en daarmee salaris. Een factor die voor velen in de krijgsmacht belangrijk zal zijn. Wel kan het betekenen dat sommige onderdelen in een overgangssituatie geen militairen met de rang soldaat zullen hebben en slechts gevuld zullen zijn met vroegere onderofficieren. Dit hoeft geen bezwaar te zijn, indien we beseffen dat de functie-inhoud het wezenlijke is waarom het draait in de krijgsmacht en de rang van een persoon feitelijk niets anders is dan zijn salarisschaal.

Een tweede optie is overtollige beroepsmilitairen in een arbeidspool te plaatsen. Tijdens de periode dat deze militairen in deze interne arbeidsreserve verblijven, zullen zij door de krijgsmacht om-, her- of bijgeschoold kunnen worden ten einde een soepele overgang naar de burgermaatschappij te maken. Daarnaast kunnen zij vanuit de arbeidspool flexibel worden ingezet op plaatsen waar gaten in de krijgsmachtorganisatie vallen of waar nieuwe onderdelen tot leven komen. Hoofdtaak van de arbeidspool is dus te zorgen voor het op niveau houden van de kennis van beroepsmilitairen en ze klaar te maken voor de nieuwe taken van de krijgsmacht of een plaats in de burgermaatschappij. Verlies aan "human capital" dient zoveel als mogelijk voorkomen te worden, terwijl alternatieve vormen van "human capital" juist opgebouwd dienen te worden.

Nadat de eerste fase van de overgang van een dienstplichtigenleger naar een vrijwilligersleger voorbij is met het laten verdwijnen van de dienstplichtigen en het reorganiseren van het overtollige bestand aan beroepsmilitairen komt de tweede fase. Deze tweede fase houdt het omzetten van de niet-gevechtsfuncties die nog bezet worden door militairen in plaatsen voor burgers in.

Dit proces kan heel langzaam geschieden met alle efficiëntieverliezen van dien, door te wachten op het moment dat militairen op zulke functies met pensioen gaan. Dit kan ook sneller worden bereikt door de niet-gevechtsfuncties niet meer in aanmerking te laten komen voor rotatiedoeleinden. Met de rotatie wordt bedoeld afwisseling in de werkzaamheden voor de beroepsmilitair te verzorgen en invulling te geven aan een loopbaanontwikkeling. Na een aantal jaren op een onderdeel te hebben 
gewerkt verlaat de beroepsmilitair zijn onderdeel en gaat hij naar een ander onderdeel en van de ene functie naar de andere. Vanuit het gezichtspunt van de krijgsmacht als werkgever komt het gebruik van rotatie voort uit twee principes: het vullen van vacatures in het personeelsbestand en het onderhouden van personeelsmanagementdoelen.

Bij het vullen van de vacatures is het belangrijk te onderkennen dat de vacatures niet alleen ontstaan door overlijden, ontslag of promotie. Belangrijk is ook dat militairen niet graag lang willen verblijven op plaatsen die veraf gelegen zijn. Dit komt tevens omdat het meestal aan de mogelijkheden ontbreekt om het personeel extra te belonen voor het feit dat in een afgelegen plaats gewerkt moet worden. De toelages die worden verstrekt voor verbliff in het buitenland zijn dan ook niet gericht op het ongemak dat het personeel heeft, maar meer op een compensatie van de meerkosten dat een verblijf in het buitenland met zich meebrengt.

Door de beroepsmilitair wordt de rotatie veelal als positief ervaren, doch voor de krijgsmacht zitten er ook negatieve aspecten aan het rotatiesysteem. Door de relatief korte duur van het verblijf in een bepaalde functie, $z$ al een beroepsmilitair niet echt een specialist worden op deze functie. Zijn meerwaarde op een vaak evoluerende functie zal daarom niet optimaal zijn, bovendien kost rotatie een hoop geld in termen van verplaatsings- en reiskosten. Bovendien zal een aantal militairen het rotatiesysteem niet als prettig ervaren. Dit zal zeker het geval zijn, indien de rotatie verplicht is. Door de verplichte rotatie zullen mensen ontslag nemen, een situatie waarmee niemand gediend is.

Het buiten beschouwing laten van de niet-gevechtsfuncties als rotatieplaats betekent dat minder plaatsen beschikbaar zijn voor militairen. Dit betekent echter ook dat er in totaal minder militairen nodig zijn en dat er dus minder mensen hoeven te roteren. Op lange termijn leidt het verminderen van het aantal rotatieplaatsen dus niet tot problemen. De roterende groep militairen wordt steeds kleiner op een steeds kleiner wordende groep functies. Op korte termijn zal de oplossing gezocht moeten worden in een langer verblijf in een bepaalde functie, rotatie niet alleen binnen het eigen wapenvak maar over alle gevechtsfuncties te laten plaatsvinden, minder inname van nieuwe militairen en opname in het specialistenteam dat nodig is om specialistische taken ten behoeve van de VN uit te voeren.

Het feit dat de niet-gevechtsfuncties niet meer in aanmerking komen voor rotatie betekent overigens niet dat militairen niet meer in aanmerking komen voor zo'n functie. Er hoeft een militair namelijk niets in de weg te staan om na zijn militaire diensttijd een tweede carriere binnen het krijgsmachtbedrijt als burger te beginnen. In sommige gevallen zijn militairen juist zeer geschikt om verder te gaan als burger, omdat zij over een bepaalde mate van specialistische kennis beschikken. Zeker in de beginfase van het overgangsproces zullen de diverse toekomstige Defensiebedrijven en -instituten hun kennis moeten halen uit de militairen die in de oude vorm van het krijgsmachtbedrijf daar reeds werkten, omdat het enige tijd kost om geschikt burgerpersoneel in dienst te hebben.

Een derde methode om het overgangsproces in de tweede fase te versnellen is het simpelweg herzien van de status van militairen in die van een burger. Door middel van de herziening van de status van militairen kan vlot worden verder gegaan met de vermaatschappelijking van de krijgsmacht, de privatisering van de krijgsmacht en het innen van efficiëntievoordelen. Militairen gaan verder als burger met het werk waiar mee ze bezig zijn. Salarisconsequenties hoeft dit niet te betekenen, daar voor iedere militaire rang een vergelijkbaar burgersalaris te vinden is. Wel zal de omzetting van militair in burger consequenties hebben voor de pensioneringsleeftijd. Toch is het de 
vraag of vele militairen nu werkelijk met 50 of 55 jaar met pensioen willen of dat ze toch willen doorwerken tot hun $62 \mathrm{e}$ of $65 \mathrm{e}$. Vaak nemen militairen na hun pensionering een andere taak op zich. Echt op hun lauweren rusten doen ze niet.

Het grote probleem bij de verandering van de status van militairen is het inruilen van het uriform voor een burgermanskostuum. Vele oudere militairen kunnen het als een grote cultuurschok ervaren, indien hun gevraagd zal worden het uniform te verruilen voor het burgerpak. De cultuur van de krijgsmacht is in het overgangsproces $z o$ 'n groot probleem dat we hierop verder zullen ingaan in paragraaf 8.5 . en het hier even laten rusten.

De overgang van een dienstplichtigenleger naar een vrijwilligersleger heeft ook consequenties voor de kapitaalzijde van het produktieproces. De substitutie van militairen door kapitaal is én van de dimensies van deze kant van het overgangsproces. Grotendeels zijn deze zaken reeds besproken in hoofdstuk 7 bij de privatisering van de krijgsmacht en in hoofdstuk 5 bij de substitutie van arbeid door kapitaal. Aan het privatiseringsproces zijn sommige noodzakelijke maatregelen nog niet nader uitgediept. In de volgende paragraaf zullen we hier verder op in gaan.

\section{\$ 8.3. De overgang van een gecentraliseerde krijgsmacht naar een gedecentraliseerde krijgsmacht}

In hoofdstuk 7 heeft de privatisering van de krijgsmacht centraal gestaan. Dit privatiseringsproces introduceert een groot aantal prikkels die de wisselwerking tussen maatschappij en krijgsmacht verbeteren en daarnaast voor een efficiëntere krijgsmacht kunnen zorgen. Willen de prikkels op een juiste wijze hun werk kunnen doen, dan is het noodzakelijk dat deze prikkels gebaseerd zijn op de juiste informatie. Met andere woorden de waarde van de produktiefactoren die de krijgsmacht gebruikt, moet weerspiegeld worden in haar prijs. Wijkt de prijs af van haar' werkelijke waarde, zoals bij dienstplichtigen het geval is, dan kan een "free-rider"-probleem ontstaan. Het gevolg van dit "free-rider"-probleem is dat de werkelijke voorkeuren ten aanzien van het gebruik van produktiefactoren niet boven tafel komen en verspilling optreedt.

Bij het doorberekenen van de diensten en produkten aan andere dellen in de krijgsmacht dient dan ook de werkelijke prijs van de dienst en het produkt in rekening te worden gebracht. Bij de verbruiksgoederen is dit geen probleem, doch bij de gebruiks of investeringsgoederen kunnen problemen ontstaan in de verrekening tussen de diverse eenheden, bedrijven en instituten in de krijgsmacht.

Willen de Defensiegebouwendienst-NV, Defensieterreinendienst-NV en het Defensiemachinepark-NV, de bedrijven die de investeringsgoederen beheren, goed kunnen functioneren, dar betekent dit dat zij de gebouwen, terreinen en machines in hun bezit moeten hebben. Momenteel zijn deze produkten in het bezit van het Ministerie van Defensie.

De gebouwen moeten dus worden overgedragen aan de Defensiegebouwendienst-NV, en wel tegen de waarde in het economische verkeer. De gebruikers van de gebouwen huren vervolgens de gebouwen van de Defensiegebouwendienst-NV en betalen daarvoor een huurprijs, welke afgeleid is van de waarde van het gebouw in het economisch verkeer. Deze methode kent echter wel een probleem. Dit probleem bestaat hieruit dat de gebruikers van een gebouw nul voor de tweede keer gaan betalen voor het gebouw. Eerst werd een bedrag ineens betaald, nu moet huur worden betald. Daarom moet de tegenprestatie van de Defensiegebouwendienst-NV uitbetaald worden aan de oorspronkelijke gebruiker wan de gebouwen. Deze 
tegenprestatie hoeft niet direct te worden betald, maar kan ook bestaan wit een schuldwordering. De Defensiegebouwendienst-NV heeft dan een schuld aan de afnemer van de gebouwen, die wordt terugbetaald uit de huuropbrengsten van deze gebouwer. Op het eerste gezicht lijkt deze constructie op het rondpompen van geld, want met het overdragen van de gebouwen om-niet aan de DefensiegebouwendienstNV en het achterwege laten van een huurprijs wordt hetzelfde eindresultaat bereikt. Echter in het laatste geval worden de afnemers van de gebouwen niet geconfronteerd met de reële kosten wan haar gebruik, waardoor prikkels voor efficiënt gebruik niet bestaan.

Bij de overgang naar een gedecentraliseerde krijgsmacht dient dus begonnen te worden met het identificeren van de gebruikers van de gebouwen, terreinen en machines. Deze gebruikers dienen vervolgens als eigenaar te worden beschouwd. De tweede stap is dat de gebouwen, terreinen en machines worden verkocht aan de diverse Defensiebedrijven, en vervolgens worden teruggehuurd. De gebruikers van de gebouwen, terreinen en machines houden een vordering op de Defensiebedrijven, die door de Defensiebedrijven onafhankelijk van het gebruik van de gebouwen, terreinen en machines wordt terugbetaald. Op deze wijze kan de financiering van het privatiseringsproces ook op soepele wijze geschieder. Mocht een onderdeel van het krijgsmachtbedrijf besluiten een deel van haar gebouwen niet meer te gebruiken, dan staat het de Defensiegebouwendienst-NV vrij daar andere gebruikers voor te vinden. Deze kunnen zowel binnen als buiten de krijgsmacht te vinden zijn. Als voorbeeld kan hier het Ministerie van Welzijn, Volksgezondheid en Cultuur dienen, die ruimte nodig heeft voor de opvang van asielzoekers. De aflossing van de schuld van de Defensiegebouwendienst-NV aan de oorspronkelijke gebruiker gaat natuurlijk gewoon door, deze kan nu betaald worden uit de opbrengsten van de verhuur aan WVC.

Gebouwen en machines zijn produkten die aan technische en economische slijtage onderhevig zijn. Gebouwen en machines worden gebouwd en na verloop van tijd weer gesloopt. De levensduur van gebouwen is dus eindig. Met terreinen is dit anders. Dat wil zeggen de grond waaruit de terreinen bestaan. De bestrating, riolering, hekwerken enz. die op de grond staan en samen met de grond het feitelijke terrein vormen zijn natuurlijk produkten die aan slijtage onderhevig zijn en zullen daardoot op de zelfde wijze behandeld moeten worden als de gebouwen en machines.

Met de pure grond is dit echter anders. Het kenmerk van grond is zijn duurzaamheid. Een dururzaamheid zelfs in die mate, dat in sommige gevallen van een eeuwigdurend produktiemiddel kan worden gesproken. Grond kan verschillende functies hebben als produktiemiddel.4 Deze functies zijn:

a) de functie van vestigingsplaats;

b) de functie van drager van vervangbare stoffen in het vegetatieve produktieproces;

c) de functie van drager van onvervangbare stolfen in het extractieve produktieproces.

Voor het krijgsmachtbedrijf is slechts de eerste functie van belang. Grond is in zijn functie als vestigingsplaats onverslijtbaar, dat wil zeggen dat grond niet aan technische slijtage onderhevig is. Indien we onderdelen van de krijgsmacht willen confronteren met de kosten van hun verbruik, dan zullen op basis van technische slijtage van de grond geen kosten in rekening kunnen worden gebracht. Dat wil zeggen, grond kan niet slijten, vervuiling van de grond kan natuurlijk altijd optreden. De kosten van het schoonmaken van de vervuiling zal door de Defensieterreinendienst- $N V$ in reke-

4. H. van der Schroeff, Kosten en kositprij)s, Amsterdam 1979, 13e druk, blz.114. 
ning gebracht moeten worden bij de vervuiler. Deze zal meestal snel op te sporen zijn. Als de gebruiker al niet de vervuiler is, dan zal de gebruiker er wel voor zorgen dat de vervuiler bekend wordt, daar zij anders zelf voor de kosten opdraait.

Grond in de functie als vestigingsplaats kan dus miet slijten in technische zin. In economische zin kan grond wel slijten. In het algemeen zal als vestigingsplaats die geografische plaats worden gekozen, die relatief gunstig ligt ten opzichte van het gebied van de afzet van een produkt en het leveringsgebied van de produktiemiddelen, zowel van kapitaal als van arbeidskrachten. Verplaatsing van die gebieden kan de bestaande vestigingsplaatsvoordelen verloren doen gaan. Als vestigingsplaats heeft de grond ter plaatse dan een verminderde betekenis, waardoor de grond in waarde kan dallen.

Voor de krijgsmacht zal de economische slijtage van de grond heel moeilijk te bepalen zijn, zo zij al niet nul is. Had de krijgsmacht voor de val van de Muur in 1989 tot taak de Noord-Duitse laagvlakte te beschermen, nu is haar takenpakket uitgebreid tot zaken die over de gehele wereld kunnen plaats vinden. De thuisbasis zal voor de nieuwe taken van de krijgsmacht in veel gevallen dezelfde blijven, waardoor van economische slijtage normaliter geen sprake is. Door de nieuwe taken kan het wel zo zijn dat nieuwe oefenterreinen of kazerneterreinen nodig zijn. De vraag is dan wie voor de financiering en de kosten van de financiering van deze terreinen moet opdraaien, daar waar het de pure grond betreft. De Defensieterreinendienst-NV krijgt geen vergoeding voor de grond, daar de grond niet verbruikt wordt. $\mathrm{Zij} \mathrm{kan} \mathrm{de} \mathrm{aankoop} \mathrm{van}$ de grond dan ook niet financieren. De financiering van de grond zal uit de algemene middelen moeten komen en kan na voorbereiding door de DefensieterreinendienstNV uitgevoerd worden door de afdeling Financieel-economische zaken van het Ministerie van Defensie: $\mathrm{Zij}$ zal de formele eigenaar van de grond $\mathrm{zijn}^{5}$, alle overige offers ${ }^{6}$ die door de grond worden opgeroepen komen dan ter verantwoording van de Defensieterreinendienst-NV, welke zij op haar beurt weer in rekening zal brengen bij de afnemers.

Voordat we deze paragraaf afronden, zullen we nog ingaan op het betalen van huur voor oefenterreinen die niet in het bezit zijn van de krijgsmacht. Niet alle terreinen waar de krijgsmacht in vredestijd gebruik van maakt zijn in haar bezit. Nu we het hiervoor in deze paragraaf hebben gehad over het feit dat grond niet slijt en dat daarom geen kosten verbonden zijn aan het gebruik van de grond, lijkt het betalen van huur voor oefenterreinen een vreemde eend in de bijt. Doch de huur wordt niet betaald doordat er sprake is van slijtage van de grond, maar vanwege een vergoeding voor de gederfde "opportunity costs" van de eigenaar van de grond. De redlen voor de krijgsmacht om de grond te huren ligt in het feit dat naar alle waarschijnlijkheid zeer weinig van de grond als oefenterrein gebruik zal worden gemaakt, waardoor de kosten van aankoop te hoog worden.

\footnotetext{
50pbrengsten uitt de verkoop van grond zullen dan ook terugvloeien naar de begroting van het Ministerie van Defensie.

6Daronder zal ook de rente behoren die door financiering van de grond eventueel betaald zal moeten worden.
} 


\subsection{De mobilisabele eenheden?}

Indien we een dienstplichtigenleger willen inruilen voor een vrijwilligersleger dienen we ook een oplossing te vinden voor de vulling van de mobilisabele eenheden. Dienstplicht bracht voor de vulling van deze eenheden een eenvoudige oplossing. $\mathrm{Na}$ de initiele opleiding was een dienstplichtige mobilisabel, ten einde als de nood aan de man was opgeroepen te worden om te dienen in de krijgsmacht. De periode die een dienstplichtige in eerste instantie doorbracht in de krijgsmacht werd dan ook omschreven als dle eerste oefening. Na deze eerste oefening kwamen dan de herhalingsoefeningen om de dienstplichtige geoefend te houden. Op deze wijze kon de krijgsmacht een groot aantal geoefende mensen krijgen voor de vulling van haar mobilisabele eenheden en de gaten die in de reguliere eenheden zouden kunnen ontstaan.

In een: vrijwilligersleger zall deze mogelijkheid op lange termijn wegvallen. $O p$ korte termijn hoeft de overgang naar een vrijwilligersleger geen problemen op te leveren voor het vullen van de mobilisabele eenheden, omdat in geval van nood nog steeds geoefende dienstplichtigen opgeroepen kunnen worden. Immers met het verdwijnen van het dienstplichtigenleger wordt niet de dienstplichtwet afgeschaft, maar verdwijnt slechts de opkomstplicht.

Met het verstrijken van de jaren zal door het verdwijnen van de opkomstplicht ook het aantal geoefende dienstplichtigen verdwijnen en zal dit tekort moeten worden ondervangen door de komst van vrijwilligers. Deze vrijwilligers, reservisten genoemd, zullen de plaatsen in de mobilisabele eenheden moeten opvullen. Hoeveel reservisten nodig zijn zal ondermeer afhangen van de doelstellingen van de krijgsmacht, doch in de hoofdstukken hiervoor hebben we gezien dat de aantallen benodigde reservisten in een vrijwilligersleger minder zullen zijn dan in een dienstplichtigenleger.

In de eerste plaats wordt het aantal reservisten dus bepaald door de doelstellingen van de krijgsmacht. Uit deze doelstellingen volgt hoeveel eenheden van die krijgsmacht een mobilisabele status hebben. In de tweede plaats wordt het aantal reservisten bepaald door de hoeveelheid materieel dat beschikbaar is ${ }^{8}$, daar de gevechtskracht van een eenheid bepaald wordt door de combinatie van kapitaal en arbeid en niet door de produktiefactoren kapitaal en arbeid afzonderlijk. Ten derde zal het aantal reservisten bepaald worden door de noodzaak gaten in eenheden op te vullen die ontstaan door het sneuvelen van soldaten. Juist in dit derde element zit een groot verschil tussen een dienstplichtigenleger en een vrijwilligersleger, zoals we gezien hebben in paragraaf 6.4.1.

In paragraaf 6.4.1. is naar voren gekomen dat de factor schatarste, die een vrijwilligersleger met zich meebrengt, tot gevolg heeft dat minder snel tot een millitaire actie zal worden overgegaan dan in het geval van een dienstplichtigenleger, omdat een actie met een vrijwilligersleger tot gevolg kan hebben dat het vrijwilligersleger zonder personeel komt te zitten. Met andere woorden, in een vrijwilligersleger zal veel zuiniger met het personeel worden omgesprongen, omdat in tegenstelling tot in een dienstplichtigenleger in een vrijwilligersleger het personeel schaars is. Het personeel in een vrijwilligersleger zal ook veel bęter beschermd worden. Dit alles leidt tot een verminderde behoefte aan reservisten.

Hoeveel reservisten nu exact nodig zijn, blijft echter een schatting. Een schatting die gemaakt zal moeten worden aan de hand van de hoeveelheid mobilisabele eenhe-

\footnotetext{
7 Deze paragraaf is ondermeer gebaseerd op: M. Binkin, US-reserve forces: the problem of the weekend warrior, The Brookings Irstitution, Washüngton, D.C., 1975.

${ }^{8}$ Zie paragraal 8.1.
} 
den, de hoeveelheid materieel, de risico"s die verbonden zijn aan eventuele acties en een schatting van de hoeveelheid acties.

Met het verdwijnen van de dienstplichtigen zullen dus vrijwillige reservisten geworwen moeten worden. Bil de werving van de reservisten staan twee mogelijkheden open. De eerste mogelijkheid sluit aan bij de werving van vrijwilligers voor de parate eenheden, waarbij in het contract de verplichting opgenomen is dat vrijwilligers na het verstrijken van het conitract voor de parate troepen nog een aantal jaren als reservist kuminen worden opgeroepen. Indien deze verplichting zonder tegenprestatie wordt opgelegd kan het voorkomen dat potentiële vrijwilligers worden afgeschrikt door de mogelijkheid een contract te tekenen, waarvan de gevolgen tot ver na afloop van de actieve diensttijd kunnen voortgaan. Om dit te voorkomen kan voor de beschikbaarheid een beloning worden gegeven. Deze beloning zal kunnen aansluiten bij de tweede mogelikheid om reservisten te werven. Deze tweede mogelijkheid is eerder besproken in paragraaf 6.2.4, waar het ging over het aantrekken van vrijwilligers voor het specialistenteam ten behoeve van VN-taken. Bij deze mogelijkheid tekenen vrijwillige reservisten een contract woor een aantal jaren, waarbij ze zich verplichten "stand-by" te zijn om taken te kunnen verrichten ten behoeve van de mobilisabele troepen.

Voor deze "stand-by" verplichting krijgen de reservisten een vergoeding. Deze vergoeding zou kunnen aansluiten bij de beloning die voormalige parate vrijwilligers krijgen voor het feit dat ze nog kunnen worden opgeroepen als reservist. Machten de reservisten worden opgeroepen, dan krijgen ze een volledige vergoeding voor hur taken. Daarbij zal ook de verzekering moeten gelden dat de reservisten terug kunnen keren naar hun oude werkgever nadat hun taak beëindigd is. Dit geldt natuurlijk ook voor de groep teservisten, die voortkomt uit de parate troepen.

Reservisten worden ook wel "weekend-strijders" genoemd. Dit heeft alles te maken met het feit dat reservisten wel moeten oefenen, willen zij inzetbaar zijn. Dit oefenen zal vooral gedurende de weekeinden gebeuren. Daarnaast zal voor de vrijwillige reservisten enige initiële opleiding noodzakelijk zijn, welke een aantal weken achter elkaar zal moeten gebeuren. Na deze basistraining kunnen zij dan ook meedraaien in de "weekend-trainingen". Ook bij de reservisten geldt dat ze behandeld dienen te worden als normale mensen, waarbij we blij moeten zijn dat deze mensen zich beschikbaar stellen als vrijwilliger. Dit betekent dat zij bij een oefening niet worden opgescheept met versleten en gebrekkig materiaal, maar dat zij gebruik kunnen maken van het materieel waarmee zij in een oorlogssituatie te maken krijgen. Daar dit materieel beschikbaar is in de mobilisatiecomplexen kan dit ook technisch te verwezenlijken zijn. Personeel om de reservisten te begeleiden is afkomstig uit de parate eenheden, daar zij bij deze parate eenheden boven de sterkte zijn geplaatst. ${ }^{9}$

De werving van de reservisten kan geschieden door het Wervings- en Selectieinstituut, terwijl de eventuele benodigde initiële opleiding door het Defensieopleidingsinstituut ter hand kan worden genomen. De kosten welke worden opgeroepen door de reservisten zullen uiteindelijk gedragen moeten worden door de eenheden war de reservisten aan toegewezen zijn.

De systematiek om de mobilisabele eenheden te vullen is dus identiek aan de systematiek welke gevolgd is om de parate eenheden te vullen. Alleen de frequentie waarmee de reservisten in de krijgsmacht aanwezig zijn verschilt van de parate troepen. Voor al het overige zal er geen verschil zijn.

\footnotetext{
92 e hierwoor hoofdstuk 5 , paragraaf 4 , woetnoot 10 .
} 


\section{\$8.5. De cultuur van de krijgsmacht}

De krijgsmacht is een hiërarchische organisatie, waarbij de lijnen van de hièrarchie van boven naar beneden lopen. In de hoofdstukken hiervoor hebben we kunnen zien dat een dienstplichtigenleger voldoet aan de kenmerken van deze hiërarchische organisatie. We hebben ook kunnen zien dat in een vrijwilligersleger de verhoudingen eigenlijk heel anders dienen te liggen. Dit uit zich niet alleen door het in paragraaf 6.4. geintroduceerde subsidiariteitsbeginsel, maar bijvoorbeeld ook door de vervanging van militairen door burgers. De burgermaatschappij kent weliswaar ook hiërarchische verhoudingen, doch deze zijn hier minder pregnant aanwezig dan in de krijgsmacht. Daar komt bovendien bij dat de krijgsmacht een bureaucratische organisatie is, waarin macht, prestige en aanzien vaak belangrijker zijn dan het inkomen dat verkregen wordt. De overgang van een dienstplichtigenleger naar een vrijwilligersleger zal voor velen in de krijgsmacht de niet prettige bijkomstigheid hebben dat die elementen waar zij hun aanzien en prestige aan ontlenen slachtoffer worden in het reorganisatieproces.

De theorie van Niskanen, welke besproken is in hoofdstuk 2 , geeft een verklaring voor het budgetmaximaliserend gedrag van ambtenaren. $\mathrm{Zij}$ is daarnaast voor het verklaren van het ontstaan en het voortbestaan van de dienstplicht van essentieel belang. Willen we de cultuur van de krijgsmacht nader bekijken, dan hebben we aan de theorie van Niskanen riet voldoende, zoals blijkt uit het werk van Haselbekke. ${ }^{10}$

Oorspronkelijk is de theorie van Niskanen in brede kring onderschreven. Geleidelijk is echter het besef doorgedrongen dat de hypothese van budgetmaximalisatie te simpel is om het complexe bureaucratische gedrag en daarmee ook de cultuur van de krijgsmacht volledig te kunnen verklaren.

De min of meer traditionele theorieën, waaronder die van Niskanen, zijn in belangrijke mate gebaseerd op formele structuren en variabelen die daar mee samenhangen, zoals begrotingen, formele beloningen, sancties, formele gezagsrelaties en dergelijke. Omdat naast het formele ook een "informeel circuit" bestaat met geheel eigen karakteristieken, schiet de traditionele theorie tekort. Wat vooral van belang is, is dat de bureaucratie niet als een holistisch, maar als een pluralistisch geheel moet worden opgevat: de meeste bureaucraten hebben zowel met onder- als met bovengeschikten te maken. Besluitvorming wordt ook in de krijgsmacht toch vooral bepaald "by exchange and trade and not by giving of orders and directives that can be "obeyed" or "disobeyed"'. Besluitvorming is met andere woorden een proces van ruill en onderhandeling, waarbij de superieur de ondergeschikte beloont voor diens gehoorzaamheid. Als de prijs, de beloning niet goed is zullen ondergeschikten niet gehoorzamen.

In de theorie van Breton en Wintrobe ${ }^{11}$ spelen vertrouwen, selectief gedrag en mededinging dan ook een grote rol. Deze neo-klassieke instrumenten vormen belangrijke elementen in hun theorie welke een reactie is op de theorie van Niskanen.

Eén van de basiselementen uit de neo-klassieke theorie is dat ruil en handel het bestaan van eigendomsrechten als grondslag hebben. We vertrouwen er op dat die rechten worden geëerbiedigd; zo niet, dan is er altijd nog de rechtspraak die én en ander kan waarborgen. Ruil karakteriseert ook de relatie tussen superieur en ondergeschikte

\footnotetext{
10 Het nu volgende gedeeltue is gebaseend op: A. G.J. Haselbekke, Profijtbeginsel en politielke besituitvorming. Leiden, 1989, bliz. 176-183. Het werk van Haselbekke is ondermeer gebaseverd op: Bretor en Wintrobe, the Logic of Bureaucratic Conduct, Cambridge, 1982.

11 Breton en Wintrobe, The Logic of Bureaucratic Conduct, Cambridge, 1982.
} 
en berust eveneens op "property rights", al zijn er in het algemeen geen wettelijke instituties om deze rechten te waarborgen. Dus moeten deze steunen op vertrowwen.

Individuen die in een bureaucratie met elkaar "ruilen" vormen onderdeel van een netwerk, dat vergelijkbaar is met een markt. Organisatietheoretici noemen de structuur van netwerken in een organisatie de informele structurur. Deze informele structuur is een variabele, waarvan omvang, complexiteit en invloed onder controle staan van de bureaucraten. Ook de formele structuur is van belang; die structurur is immers een middel voor de meerdere om het gedrag van hun ondergeschikten te beinvloeden. Het toezicht houden op het gedrag van ondergeschikten moet in een bureaucratie voor een belangrijk deel door de bureaucraten zelf geschieden. Dit toezicht is in een wereld die gebaseerd is op vertrouwen van een ander karakter dan in een wereld met contractueel afdwingbare relaties.

Volgens de bureaucratietheorie van Niskanen hebben bureaucraten alleen oog voor hun eigen belang. Zij kunnen hierbij kiezen voor een coöperatieve, efficiënte houding conform het Weberiaanse model, of een inefficiënte, disloyale houding volgens het model van Niskanen. Ze gedragen zich dus selectief. Selectiviteit leidt tot een minimalisatie van de "outputkosten" wanneer bureaucraten zich efficiènt gedragen en tot een maximalisatie bij inefficiënt gedrag.

Wat er feitelijk gebeurt is afhankelijk van de informele diensten die de bureaucraten kunnen leveren door middel van hun netwerken. De informele diensten manifesteren zich in verschillende vormen, zoals versnellingen of vertragingen in de uitvoering van diensten, veranderingen in de stroom van informatie of opdrachten wanneer deze door de hiêrrarchie gaan, variaties in de omvang en kwaliteit van de informatie die uitlekt naar andere bureaus en naar de media, en dergelijke.

Bij de overdracht van informa tie zal er bovendien altijd een zekere mate van ruis optreden. Het gaat er echter om of deze ruis bewust groter of kleiner wordt gemaakt. Dit is erg moeilijk te achterhalen, omdat nooit zeker is of bepaalde berichten bewust worden vervormd of dat die vervorming het gevolg is van de natuurlijke ruis. Daamaast is een zekere mate van weglekken van informatie onontkoombaar. Daarom is er ruimte voor bureaucraten om te manipuleren. Zo zullen ze, tegen wil en dank van hun superieuren, zaken vervormen of laten uitlekken als ze er zelf beter van denken te worden.

Indien bureaucraten deze instrumenten willen hanteren moet er sprake zijn van netwerken; er is immers ruil en handel nodig bij het hanteren van die instrumenten en dat kan alleen maar in netwerken die gebaseerd zijn op basis van vertrouwen. Selectief gedrag is de uitkomst van een onderhandelingsproces tussen superieuren en ondergeschikten enerzijds en tussen ondergeschikten onderling anderzijds en wordt bepaald door de beloning die wordt geboden voor efficiènt gedrag met betrekking tot het aanbod van informele diensten. De informele diensten zijn manifestaties van selectief gedrag. Soms komen ze overeen met wat de superieur wil, soms druisen ze daar tegen in.

Of er op een efficiënte dan wel inefficiënte wijze door de bureaucraten informele diensten worden aangeboden hangt af van de mate van vertrouwen tussen sponsor: en bureaucraat, van het vertrouwen tussen bureaucraten onderling en tenslotte van het risico dat wordt gelopen bij een inefficiënt aanbod van diensten, hetgeen voor een belangrijk deel afhankelijk is van de omvang en de kosten van het toezicht. Vertrouwen is belangrijk omdat de "property rights" in het ambtelijke ruilproces niet op een wettelijke basis rusten, zoals bij het ruilverkeer in de markt. Informele diensten in de bureaucratie worden verhandeld tegen informele diensten op een ander tijdstip en in een andere vorm. Op het moment van levering van de eerste dienst is in het al- 
gemeen niet bekend welke tegenprestatie wanneer kan worden geleverd. Binnen bureaucratieën moet er op worden vertrouwd dat de tegenprestatie te zijner tijd tot stand komt.

Binnen bureaucratieën treden uiteraard ook conflicten op. Conflicten, ofwell mededingingsproblemen, vormen een dominant aspect van de burea ucratie. Er is bijvoorbeeld mededinging op het gebied van het personeel, mededinging met betrekking tot netwerkrelaties of de deelname in die netwerken ("the old boys network") en mededinging tussen bureaus onderling. Mededinging zal daarbij niet altijd overeenkomen met vertrouwen.

Haselbekke komt op basis van de hiervoor besproken theorieën tot de conclusie dat de elementen formele en informele structuur, vertrouwen, selectief gedrag en me. dedinging een betere verklaring voor het feitelijke bureaucratische gedrag geven dan op basis van de traditionele theorieenn te verwachten is. Voor ons is het nu interessant om te zien in hoeverre de door Haselbekke genoemde elementen belangrijk zijin voor de cultuur van de krijgsmacht. En indien dit inderdaad het geval is of deze elementen ons instrumenten kunnen aangeven welke voor de overgang van een dienstplichtigenleger naar een vrijwilligersleger van belang zijn.

Voor een succesvolle overgang van een dienstplichtigenleger naar een vrijwilligersleger is de cultuur van de krijgsmacht én van de dominante factoren. Vele reorganisaties zijn mislukt omdat de cultuur van de organisatie zich niet verdroeg met het reorganisatieproces. Ook voor de krijgsmacht is het niet ondenkbeeldig dat een overgang zoals beschreven in dit hoofdstuk mislukt.

De krijgsmacht is een sterk hiërarchisch geörienteerde organisatie, met een sterke hang naar traditie en prestige. Voor vele millitairen is het rangenstelsel een heilig fenomeen en vervullen zij hun functie in de krijgsmacht vanuit een roeping en niet omdat het een beroep is. Hun uniform speelt daarbij een belangrijke rol. Als er én organisatie is, waar het model van Niskanen nog op éen of andere manier is terug te vinden dan is het de krijgsmacht. Niskanen ontwikkelde zijn theorie dan ook vanuit zijn bevindingen in de krijgsmacht van de Verenigde Staten. Zouden we op basis van de theorie van Niskanen de krijgsmacht reorganiseren, zoals beschreven is in de hoofdstukken hiervoor in dit proefschrift en de paragrafen van dit hoofdstuk, dan is zo'n reorganisatie tot mislukken gedoemd. De overgang van een dienstplichtigenleger naar een vrijwilligersleger zal dan weinig anders inhouden dan de opbouw van een vrijwilligersleger op de fundamenten van het dienstplichtigenleger, met andere woorden: de dienstplichtigen worden op een én-staat-tot-én-basis vervangen door beroepsmilitairen. Alle overige substituties en veranderingen zullen naar alle waarschijnlijkheid sneuvelen in het budgetmaximaliserend bureaucratisch geweld. Een voorbeeld van dit niet opwekkende scenario speelt in de praktijk bij de onderhoudsdiensten van de krijgsmacht. ${ }^{12}$ Uit dit voorbeeld blijkt dat het voor een goed func tioneren van deze onderhoudsdiensten noodzakelijk is dat een verregaande samenwerking tussen de 30 onderhoudsbedrijven in de krijgsmacht wordt gemaakt. Echter volgens een direct betrokkene:

"De cultuurverschillen tussen Landmacht, Luchtmacht en Martne zijn groot. Ik karr me voorstellen dat de militairen in de bedrijfsleiding niet zo over ohs voorstel staan te springen. Het betekent namelijk de afbrokkeling van hun macht. Niemand vindt het leuk om macht af te staan" "13

${ }^{12}$ Zie het ledenblad van de FNV-bond Abwa-Kabo "Aaneem", 29 augustus 1992, blz. 8. "Niemand stalat graag macht af.

13 dam. 
De samenvoegiling van de onderhoudsbedrijven komt dan ook niet van de grond. Ook de wervarging van de militairen in deze organisatie, welke vaak alleen maar aan de top van de organisatie zijn terug te vinden, door burgers komt niet van de grond.

Wil de overgang van een dienstplichtigenleger naar een vrijwilligersleger een succes worden dan moet dus uit een ander vaatje worden getapt. Duidelijk moet zijn dat de mensen in de krijgstmacht die liets in moeten leveren een gelijkwaardige contraprestatie krijgen, anders goolen zij hun lichaam tegen de kribbe. Om een goed oog te krijgen op deze contraprestatie zal aansluiting gezocht moeten worden bij de elementen die door Haselbekke naar voren zijn gebracht.

Deze elementen kunnen er voor zorgen dat de reorganisatie wel een succes wordt. Of dit in de praktijk ook zo zal zijn zal de toekomst moeten uitwijzen.

Besluitvorming is vooral een proces van ruil en onderhandeling, welke gebaseerd is op vertrouwen. Dit is zeker het geval in een gecentraliseerde krijgsmacht waarin vrijwel geen ruimte is voor echte "property rights". Bij een reorganisatie is dus de eerste vereiste dat er een bepaalde mate van vertrouwen is. Vertrouwen is ondermeer gebaseerd op informatieoverdrachten. Voor een succesvolle reorganisatie zal de hoeveelheid ruis in de organisatie tot een minimum beperkt moeten worden. Juist om dit te bewerkstelligen zal iedere schakel in de krijgsmacht mee moeten werken.

Een reorganisatieproces begint bovenaan in de hiërarchie. Hier dient de politiek te constateren dat de oorspronkelijke opdracht niet meer voldoet en dat verandering noodzakelijk is. Zonder de politieke wil om te veranderen zal sowieso niets gebeuren. De politiek moet het veranderingsproces in gang zetten en zal daarvoor zijn directe ondergeschikten ansporen dit uit te voeren. Deze ondergeschikten zullen hiermee instemmen indien ze voldoende wisselgeld krijgen, waarmee ze de idee hebben dat ze er niet op achter uit gaan, op welke wijze dan ook. Maar deze ondergeschikten zijn weer de superieuren van andere ondergeschikten. Ook hier zal een rullproces in gang worden gezet, welke er voor moet zorgen dat met de ultvoering van het reorganisatieproces wordt voortgegaan, maar dat de ondergeschikten daar in hun gedachten niet slechter van worden. Deze ruilprocessen zetten zich op ieder niveau voort, waarbij de reorganisatie als onafwijsbaar uitgangspunt geldt en op ieder niveau prestatie en tegenprestatie voor de betrokkenen ongeveer in evenwicht moeten zijn.

Voor de overgang van een dienstplichtigenleger naar een vrijwilligersleger levert dat ondermeer de volgende vragen op:

- Hoe snel verdwijnen de dienstplichtigen en wat voor beroepsmilitaiten krijg ik er voor terug?

- Indien de wedde van dienstplichtigen naar beroepsniveau wordt opgetrokken, heeft dit dan werkelijk effect op de werving van beroepsmilitairen en het kostenbesef in de krijgsmacht of dient het optrekken van de wedde naar beroepsniveau alleen maar als compensatie voor die dienstplichtigen, waar we niets voor terug zien?

- Militairen zullen niet gemakkelijk afstand doen van hun uniform, om als burger verder te gaan in de krijgsmacht. Wat is er voor nodig om ze wel zover te krijgen. Meer salaris, een langer dienstverband?

- Ontslag behoort tot de mogelijkheden, maar welk sociaal plan staat daar tegenover? Al deze vragen en nog veel meer zijn relevant voor de overgang naar een vrijwilligersleger. Telkens staan prestatie en contrapresatie tegenover elkaar. Deze voortdurende afweging kost geld. Geen enkele geslaagde reorganisatie gaat zonder reorganisatiekosten.

De reorganisatie gaat mis indien prestatie en contraprestatie te ver uiteenlopen. Dit kan ondermeer gebeuren omdat onvoldoende informatie beschikbaar is op basis waarvan beslissingen moeten worden genomen, waardoor grote onzekerheid bestaat. 
Ook kan informatie bewust zijn vervormd. Inefficiënties zullen zich ook voordoen indien geen overeenstemming wordt verkregen, en zich conflicten gaan ontwikkelen.

Het is vrijwel onmogelijk om een uitputtende opsomming van alle facetten van een succesvolle overgang van een dienstplichtigenleger nat een vijiwilligersleger weer te geven. Wel is het duidelijk dat een reorganisatie in overeenstemming moet zijn met de wetten van de bureaucratie, waarbij de elementen vertrouwen, selectief gedrag en mededinging een beslissende rol spelen. Verontachtzaming van deze elementen zal naar alle waarschijnlijkheid leiden tot een mislukking van het reorganisatieproces. Een goed inzicht in de juiste verhoudingen van deze elementen in de. krijgsmacht kan het reorganisatieproces ten goede komen en zelfs versterken.

Een reorganisatie is een proces van lange adem, waarbij de cultuux van een organisatie veelal het succes bepaalt. Zelfs indien de cultuur van de organisatie gevoelig is voor de juistheid van de reorganisatie, zal het enige tijd duren voordat een reorganisatie zijn vruchten afwerpt. Daarom kan bij een reorganisatie niet alles tegelijk gebeuren. De organisatie raakt anders oververhit door de veranderingen. De overgang van een dienstplichtigenleger naar een vrijwilligersleger dient dan ook in stappen te gebeuren. Deze stappen zijn uitgelegd in de paragrafen 8.2 en 8.3 .

De krijgsmacht dient eerst omgezet te worden van een organisatie die alleen naar haar produkt kjkt, naar een organisatie die ook naar de markt kijkt; met andere woorden, de krijgsmacht moet eerst worden omgezet van een organisatie zonder veel schaarste-invloeden naar een marktgerichte organisatie, waar oog is voor schaarse produktiemiddelen. Als dit proces achter de rug is kan verder worden gegaan met de decentralisatie van de krijgsmacht. In de eerste periode kunnen bepaalde voorzieningen wel worden opgezet welke in de overgang naar een gedecentraliseerde krijgsmacht direct van dienst kunnen zijn, zoals de veranderingen ten aarzien van de boekhouding en het informatieproces.

Hoewel we ons bewust zijn van het feit dat er nog vele opmerkingen aan deze paragraaf kunnen worden toegevoegd, stoppen we ermee in deze paragraaf, omdat additionele opmerkingen te veraf liggen van het initiële onderzoeksdoel: de militaire dienstplicht. In deze paragraaf is een indicatie gegeven van de problemen die de cultuur van een organisatie als de krijgsmacht kan oproepen. Een volledige uitwerking gaat de probleemstelling van het proefschrift echter te boven.

\section{$\S 8.6$. Slotopmerkingen}

In dit hoofdstuk heeft de overgang van een dienstplichtigenleger naar een vrijwilligersleger centraal gestaan. Voorafgaande aan zo'n overgang dient de vraag te worden gesteld of we die overgang wel willen hebben. Indien we dit hoofdstuk en de vorige hoofdstukken overzien, dan kunnen we stellen dat een vrijwilligersleger momenteel te prefereren is. Indien we reeds een vrijwilligersleger zouden hebben gehad dan zou ons er veel aan gelegen zijn om dit vrijwilligersleger te behouden. Eigenlijk is het vreemd dat een vrijwilligersleger niet eerder tot stand is gekomen, daar een vrijwilligersleger zowel in maatschappelijk als in budgettair opzicht veel goedkoper is dan een dienstplichtigenleger, en een vrijwilligersleger de krijgsmacht het besef geeft met schaarse middelen om te gaan, waardoor tevens de effectiviteit van de krijgsmacht verbetert.

Het is zaak het dienstplichtigenleger van nu om te zetten in het vrijwilligersleger van de toekomst. Dit betekent bovenal dat we ons op de toekomst dienen te richten en de erfenis van de dienstplicht dienen te vergeten. Een vrijwilligersleger is een profes- 
sioneel leger met oog voor de capaciteiten van de individuele schaarse mens, dat opgebouwd dient te worden volgens de wetten van een professionele organisatie. Dit betekent dat een vrijwilligersleger geen voortzetting kan zijn van het kader-militieleger dat het dienstplichtigenleger als uitgangspunt had. Een vrijwilligersleger heeft Nederland echter in geen 200 jaar gekend. Het zal naar alle waarschijnlijkheid dan ook veel moeite kosten om afstand te doen van het dienstplichtigenleger, doch een vrijwilligersleger zal slechts een volledig succes worden indien het dienstplichtigenleger zo snel mogelijk wordt vergeten.

In dit hoofdstuk hebben we gezien waar voor dit succes de grootste bottlenecks liggen. De cultuur van de organisatie, welke 200 jaar vrijwel zonder schaarste-elementen heeft kunnen omgaan, zal moeilijk veranderen. Ervaringen in het buitenland in deze, zoals de vrijwilligerslegers in de Verenigde Staten en Groot-Brittannië, spreken hiervan boekdelen. In de Verenigde Staten en Groot-Brittannië zijn de vrijwilligerslegers omgebouwd op de fundamenten van de dienstplichtigenlegers. De vrijwilligerslegers zijn een groot succes, maar wel verschrikkelijk prijzig door een onvoldoende besef van de omgang met schaarse middelen. Als we een dienstplichtigenleger omzetten in een vrijwilligersleger dan moet ook deze kant van het overgangsproces een succes worden. In dit hoofdstuk is aangegeven hoe dat zou kunnen. 


\section{Sociale dienstplicht}

"Niemand heeft ooit beweerd dat het gemakkelijk is om mensen bewust te maken van het geluk dat hun toekomt. Naastenliefde vereist nu eenmal de strenge, maar ook rechtvaardige hand van sociale dienstplichtigen. In deze morele krachtmeting vallen slachtoffers, dat is onvermijdelijk. Bij dienstplicht hoort nu eenmaal oorlog."

Paul Scheffer, NRC-Handelsblad, 16-10-1992, Opiniepagina.

Militaire dienstplicht en sociale dienstplicht worden vaak beschouwd als broertje en zusje. Een discussie over de militaire dienstplicht wordt vaak vervolgd met een discussie over de sociale dienstplicht. In dit proefschrift stat de militaire dienstplicht centraal, echter een klein uitstapje naar de sociale dienstplicht is niet helemaal buiten de orde, omdat de economische mechanismen die eerdier beschreven zijn voor de militaire dienstplicht ook voor de sociale dienstplicht gelden. Bovendien kan een analyse van de sociale dienstplicht een nader licht werpen op onderdelen van de militaire dienstplicht, die anno 1993 voor de militaire dienstplicht niet meer van belang zijn, maar" onder andere omstandigheden eventueel wel belangrijk zouden kunnen zijn. Met vooraf de opmerking dat de militaire dienstplicht bestaat en op het punt staat te verdwijnen, en de sociale dienstplicht niet bestaat, terwijl over de invoering juist gesproken wordt.

\section{\$9.1. Inleiding}

Sociale dienstplicht wordt omschreven als:

"Gedurende een bepaalde periode verplicht verrichten van werkzaamheden, waaraan aantoonbare maatschappelijke behoeften bestann" 1

Alls primair uitgangspunt voor het instellen van een sociale dienstplicht wordt door het CDJA gesteld dat iedereen zich naar vermogen dient in te zetten voor de maatschappij. Daarbij wordt geconstateerd dat er een aantal taken in de maatschappij blijven liggen die nu niet worden uitgevoerd, omdat er geen geld voor is. Een derde argument is dat er een hoeveelheid vuil en onaangenaam werk in onze maatschappij bestaat dat niet wordt geklaard.. Ten vierde is er de kwestie van de gelijkberechtiging.

\footnotetext{
${ }^{1}$ Definitie gehanteerd door het CJDA, de jongerenorganisatie geassocieerd met het CDA. Deze definitie is te vinden in: EJ. Kleingeld en R. Rolleman, Sociale dienstplicht, dwangarbeid of solidariteit? Utrecht april 1990, bly.14.
} 
Niet alleen de milltair dienstplichtigen, maar alle jongeren zullen zich een bepald deel van hun leven ten dienste moeten stellen van de maatschappij.

Als viffde argument wordt genoemd de bestrijding van de werkloosheid en de mogelijkheid om werklozen een betere kans op de arbeidsmarkt te geven door ze ervaring en scholing in de maatschappij op te laten doen.

Uit deze argumenten blikt dat het pleidooi voor de sociale dienstplicht vooral wordt gevoed door praktische constateringen. Het verplicht verrichten van werkzaamheden tegen een bepaalde, soms lage, vergoeding zou hiervoor de remedie moeten zijn.

Van een serieas onderzoek naar de sociale dienstplicht is nog maar weinig terecht gekomen. Ondanks verzoeken van de Tweede Kamer aan de Ministers vain Defensie en Sociale Zaken om zo'n onderzoek op te zetten is dit niet gebeurd. Wel heeft het Sociaal en Cultureel Planbureau ten behoeve van de Commissie Meijer de "ins" en "outs" van de sociale dienstplicht op een rijtje gezet. In de volgende paragraaf zullen we dit ook doen. Daarbij gaan we uit van de argumenten welke worden aangedragen door het CJDA. Bij deze argumenten zullen we aansluiting zoeken bij de methoden die eerder in dit proefschrift zijn gebruikt bij het analyseren van de militaire dienstplicht. Bij deze analyse zullen we ook aandacht besteden aan de eventuele opbrengsten van de millitaire dienstplicht, door middel van een analyse van de leereffecten door de dienstplicht op meso-economisch en macro-economisch niveau.

\section{\$9.2. Sociale dienstplicht: de theorie}

Het kenmerkende element van de sociale dienstplicht is haar verplichte karakter. Door dit verplichte karakter wordt een belasting-in-natura geintroduceerd ter grootte van het verschil tussen de "opportunity costs" van een sociaal dienstplichtige en de vergoeding die de sociaal dienstplichtige ontvangt. De grootte van deze belasting wordt bepaald door de sommatie over alle dienstplichtigen van het verschil tussen de "opportunity costs" en de vergoeding die daar tegenover staat. De "opportunity costs" houden aok in dit geval zowel de materiële als de immateriële kosten in.

De immateriële zijde van de "opportunity costs" is belangrijk, omdat juist de immateriële kosten en baten duidelijk kunnen maken waarom mensen sommige taken als vrijwilliger ter hand nemen, zonder dat daar een geldelijke vergoeding tegen overstaat. Wrijwilligers nemen werk ter hand, omdat de baten die zil persoonlijk erwaren in ruime mate opwegen tegen het verlies aan mogelijke geldelijke inkomsten. Indien deze twee elementen niet tegen elkaar opwegen, zal de vrijwilliger zijn werk staken of er niet aan beginnen. Vrijwilligers zijn schalars, omdat zij zelf de beslissing nemen zich aan te bieden als arbeidskracht. Bij sociaal dienstplichtigen is dit niet zo. Dienstplichtigen worden verplicht en daarmee verdwijnt ook het schaarste-element.

Sociale dienstplicht introduceert een belasting-in-natura. Deze sociale last drukt op de maatschappij, zoals iedere belasting dit in feite doet. Het enige verschil in deze is dat deze belasting-in-natura niet in de politieke indicatoren, zoals de collectieve lasterdiruk, terug te vinden is. Dit wil niet zeggen dat de belasting-in-natura niet aanwezig is, maar dat de politieke indicator een onvoldoende beeld geeft van de werkelijk last voor de maatschappij.

De grootte van de belasting-in-natura kan ons inzicht geven in welk bedrag aan geldelijke beloning ongeveer nodig is voor een vrijwillige vervulling van de functies die door de social dienstplichtigen worden verwuld. Sociale dienstplicht is dus geen middel om te voorzien in publieke voorzieningen zonder dat daarbij ook een last voor 
de maatschappij ontstaat. Sociale dienstplicht brengt een verschuiving in de belastingheffing teweeg. Belastingen in geld worden ingeruild voor belastingen-in-natura. De collectieve lastendruk blijf dezelfde, daar zichtbare belastingen slechts worden vervangen door verborgen belastingen met in principe dezelfde grootte.

Sociale dienstplicht is een belasting die de relatieve prijsverhoudingen van de produktiefactoren verstoort. De maatschappelijke kosten welke worden opgeroepen door de sociale dienstplicht worden niet gereflecteerd in de prijs van de produktie. middelen waardoor er een "excess burden" ontstaat. Deze "excess burden" manifesteert zich in een aantal vormen. Allereerst zijn er de inningskosten. Deze inningskosten van de sociale dienstplichitbelasting komen overeen met de inningskosten welke besproken zijn in hoofdstuk 4 van dit proefschrift. Bij een algemene invoering van de sociale dienstplicht moeten in Nederland zo"n 200.000 jongeren per jaar voor een periode van een jaar te werk worden gesteld. Niet iedereen zal daarbij in een functie komen die aansluit bij zijn opleiding. Ten einde er voor te kunnen zorgen dat de sociaal dienstplichtige inderdaad aan de vervulling van zijn functie toekomt, zal hij of $z i j$ eerst opgeleid moeten worden. Bovendien zal hij of zij als gevolg van zijn onervarenheid bij de praktische uitvoering ter zijde gestaan moeten worden door lemand die toezicht over deze werkzaamheden houdt. Indien dit niet gebeurt zal de kwaliteit van de voorziening, zoals de dienstverlening naar het publiek, onder druk komen te staan.

Vraag en aanbod van werk zullen op elkaar afgestemd dienen te worden. Daar bij sociale dienstplicht het schaarste element verdwenen is, zal het coördinatiemechanisme van de markt vervangen moeten worden door een ander coördinatiemechanisme. Deze vervanging brengt uiteraard kosten met zich mee. Bovendien zullen vraag en aanbod vaak geografisch ook niet op elkaar aansluiten, waardoor tevens geld nodig is voor de nodige reis- en huisvestingskosten. Een laatste direct zichtbare kost van de sociale dienstplicht is dat de sociale dienstplichtigen ook over werkkleding dienen te beschikken.

De verstoring van de relatieve prijzen van de produktiemiddelen in de sectoren waar sociaal dienstplichtigen worden ingezet betekent ook dat een aantal substituties in gang worden gezet. Deze substituties zijn vergelijkbaar met de beschreven substitutieprocessen in hoofdstuk 5 van dit proefschrift. Van de daar beschreven substituties zijn met betrekking tot de sociale dienstplicht vooral de substitutie van kapitaal door arbeid en ervaren arbeid door onervaren arbeid van belang.

De mogelijkheid van de vervanging van kapitaal door sociaal dienstplichtigen zal vooral afhangen van de technische mogelijkheden. Kijken we slechts naar de huidige technische mogelijkheden dan zal de vervanging van kapitaal door sociaal dienstplichtigen niet zoveel om handen hebben. De efficiëntieverliezen zullen slechts gering zijn. Doch als naar de toekomst wordt gekeken wordt deze beoordeling heel anders. Door de "oneindige" beschikbaarheid over sociaal dienstplichtigen zullen er nog maar" weinig prikkels ontstaan om sociaal dienstplichtigen te vervangen door nieuwe technische mogelijkheden, of om deze technische mogelijkheden te ontwikkelen. Het ontbreken van prikkels leidt tot een hoge mate van inefficiëntie.

Sociale dienstplicht makt onervaren arbeidskrachten goedkoop. Daardoor zullen na verloop van tijd ervaren krachten vervangen worden door onervaren krachten. In de krijgsmacht hebben we kunnen zien dat dit leidt tot een situatie waarin vrijwel geen professionele soldaten zijn. Sociale dienstplicht leidt met andere woorden tot verdringing van de professionele arbeid. Deze reguliere werknemers worden verdrongen in het arbeidsproces of komen op toezichthoudende niet-produktieve func- 
ties terecht. Dit proces zal heel geleidelijk werkelijkheid worden bij het instellen van een sociale dienstplicht.

Sociale dienstplicht leidt tot herallocatie wan produktiemiddelen. Het produktieproces zal arbeidsintensiever worden, maar ook vele malen inefficiënter. Socialle dienstplicht heeft impliciet tot gevolg dat kwalitatief hoger personeel wordt verdrongen uit de produktieve functies door kwalitatief minder personeel. Indien we als gemeenschap nog steeds dezelfde hoeveelheid collectieve goederen willen, betekent dit dat de kosten van het produktieproces omhoog zullen gaan. Er zal geen sprake kunnen zijn van de minimalisatie van de kosten, zowel in maatschappelijke als in budgettaire termen.

De gevolgen voor de werkloosheid zijn dan ook niet op voorhand te voorspellen. Sociale dienstplicht verplicht mensen ergens te gaan werken. In die sectoren wordt het arbeidsproces arbeidsintensiever, waardoor de werkloosheid per saldo afneemt, ook indien we rekening houden met het afvloeien van de reguliere arbeidskrachten. Aan de andere kant gaat door de inefficiëntie van het produktieproces de collectieve lastendruk omhoog, indien we de collectieve voorzieningen op peil willen houden De verhoging van de collectieve lastendruk leidt vervolgens tot allerlei afwentelingsprocessen, waardoor de werkloosheid weer toeneemt. Dit laatste komt ook door een forse toename van de druk op de arbeidsmarkt als gevolg van het verdwijnen van zo'n 200.000 arbeidskrachten uit de reguliere arbeidsmarkt. Dit zal in diverse sectoren tot grote arbeidstekorten leiden met als gevolg dat de lonen omhoog zullen gaan en het afwentelingsproces zich nogmaals doorzet.

Het uiteindelijke effect op de werkloosheid is door de vele herallocatie- en afwentelingsprocessen nogal diffuus. Wat de verborgen werkloosheid betreft zall het alleen maar slechter worden. Door de substitutie van onervaren voor ervaren mensen zal het aantal toezichthouders en ander niet-produktief personeel alleen maar toenemen. Vele mensen zullen nodig zijn om het proces van de sociale dienstplicht gaande te houden, terwijl dit in een wereld van schaarste in grote mate toch door de arbeidsmarktmechanisme had kunnen geschieden.

De verborgen werkloosheid neemt door de sociale dienstplicht toe, maar is op het eerste gezicht moeilijk te ontdekken daar zij een verborgen karakter heeft. Doch hier geldt hetzelfde als wat bij de substitutie van kapitaal voor arbeid is gezegd; de lange termijn verschijnselen zullen de werkelijke effecten laten zien. Wij kunnen dan wel niet ver in de toekomst kijken, ervaringen met de socialle dienstplicht in extreme vormen, zoals in het voormalige Oost-Europa, mogen hier toch zeker wel als schrikbeeld fungeren.

Sociale dienstplicht introduceert tevens verveling, omdat dienstplichtigen nu eenmaal geen ontslag kunnen nemen. Verveling is een uiting van misallocatie in een sector en komt voort uit het verplichte karakter van de sociale dienstplicht. Al deze verschijnselen leiden er ook weer toe dat het imago van het beroep dat uitgeoefend wordt daalt.

Het gevaar van de sociale dienstplicht is dat we door de verschillende mechanismen die de sociale dienstplicht initieert in een neerwaartse spiraal terecht kunnen komen. Sociale dienstplicht leidt tot maatschappelijke inefficiënties, welke weer kunnen leiden tot een herschikking van prioriteiten, waardoor weer nieuwe gaten ontstaan, die weer opgevuld moeten worden door sociale dienstplichtigen. De geschiedenis en de ontwikkeling van de militaire dienstplicht zoals beschreven in hoofdstuk 3 van dit proefschrift spreekt hiervan boekdelen. Is een sector eenmaal in de neerwaartse spiraal terecht gekomen, dan zal het zeer moeilijk zijn daar weer uit te komen. 
Na al deze mistroostige woorden over de sociale dienstplicht in theorie zullen we aan het einde van deze paragraaf ingaan op de voordelige kanten van de sociale dienstplicht. Sociale dienstplicht heeft een leereffect. Door de sociale dienstplicht leren vele jongeren de samenleving ook eens op een andere manier kennen. Dit kan zowel op een positieve als op een negatieve wijze geschieden, doch beide varianten leiden tot een vermeerdering van de kennis van de maatschappij. Zo vindt eénderde gedeelte van de militaire dienstplichtigen dat zij lets leren van hun diensttijd, eénderde gedeelte vindt dat de diensttijd hun niets bijzonders heeft bijgebracht, en eenderde gedeelte vindt dat zij van de diensttijd alleen maar slechter is geworden. 2

Tot dusver is er in dit proefschrift echter weinig aandacht besteed aan de leereffecten van de dienstplicht in een wat bredere zin dan de leereffecten van de dienstplicht op een micro-economisch niveau. Zo hebben we in hoofdstuk 4 , paragraaf 3 wel gezien dat door de dienstplicht een ervaringsachterstand wordt opgelopen, omdat dienstplichtigen door hun verplichte deelname in de krijgsmacht niet verder kunnen met het werk waar zij feitelijk voor opgeleid zijn. Hun opgebouwde human-capital blijft stilstaan of gaat zelfs achteruit. Voor het overgrote deel van de dienstplichtigen is dit inderdaad ook het geval.

Hiervoor hebben we ook gezien dat van de dienstplichtigen énderde gedeelte vindt dat zij iets van dienstplicht opsteekt, éenderde vindt dat de dienstplicht hun meer slechte dingen dan goede leert en eenzelfde gedeelte vindt dat de dienstplicht voor zichzelf geen bijzondere leereffecten hebben. Doch hier hebben we het slechts over de leereffecten van de dienstplichtige zelf. Dienstplicht kan ook leereffecten hebben voor de directe omgeving waaruit de dienstplichtige voortkomt, terwijl bovendien leereffecten denkbaar zijn voor de gehele samenleving waarvan deze dienstplichtige deel uit maakt.

In de hoofdistukken voorafgaand aan dit hoofdstuk over sociale dienstplicht is vrijwel geen aandacht besteed aan de leereffecten op meso- en macro-economisch niveau. De reden hiervoor is dat deze leereffecten anno 1993 geen grote rol van betekenis in Nederland spelen. Zo is in de analyse over de keuze tussen een dienstplichtigenleger en een vrijwilligersleger en de figuren in hoofdstuk 8 geen aandacht besteed aan deze leereffecten. Waarom dit zo is, zal in dit deel van deze paragraaf nader worden uitgelegd. Daarbij zal tevens worden ingegaan op de voorwaarden waarbij de leereffecten op meso- en macro-economische niveau wel opgeld kunnen doen. $\mathrm{pp}$ basis van deze voorwaarden kunnen we dan zien of de leereffecten voor de sociale dienstplicht wel van belang zijn.

De leereffecten van de dienstplicht op meso-economisch niveau kunnen we het beste illustreren door terug te gaan naar de inhoud van paragraaf 3.2 van hoofdstuk 6 , welke handelt over wervings- en selectieproces binnen een vrijwilligersleger. In deze paragraaf stelden we:

"De les die uit deze paragraaf getrokken kan worden is dat het gebruik van classificatiesystemen en het
stellen van selectiegrenzen een groot maatschappelijk belang heeft. Niet alleen kost het stellen van
hoge selectiegrenzen weel geld in termen van extra salaris en wervingskosten, veel belangrijker is het
de sociale gevolgen van deze eisen onder ogen te zien.
Het weigeren van "potentieel minder geschikte" wrijwilligers heeft niet alleen gevolgen voor de vrijwil-
liger zelf, maar ook voor het gezin en de ongeving waar deze vrijwilliger uit voort komt. Voor de vrij-
willigers is er het gemis aan arbeidservaring, scholing en zelfvertrouwen. Voor de gezimnen is het extra
inkomen vaak ook van harte welkom, maar nog meer maken gezinnen gebruik van intergenerationele

${ }^{2}$ Onderzoek SMK-VVOM, Dienstplicht zin, togenzin en toekomst, Den Haag, oktober 1992, blz 13. 
apbrengsten doot de ervaringen van de vrijwilliger. Ook zal zijn omgeving er eventueel woordeel mee hebben, indien de vrijwilliger als voorbeeld voor de rest gaat dienen."

Hoewel het op het eerste gezicht vreemd lijkt de leereffecten van de dienstplicht op meso-economisch niveau uit te leggen aan de hand van de mogelijkheden van het vrijwilligersleger, komt uit het voorbeeld wel naar voren, wanneer deze leereffecten zich voor kunnen doen. Hoge selectiegrenzen sluiten grote groepen jongeren uit van de mogelijkheid gebruik te maken van de sociale voordelen van het werken in een organisatie als de krijgsmacht. Door het werk in de krijgsmacht kunnen jongeren in contact komen met een andere omgeving als zij zelf kennen, of met een omgeving waar zij nooit toe zouden kunnen toetreden.

Dit laatste speelt vooral een rol bij een dienstplichtsysteem waarbij de dienstplicht niet algemeen is in die zin dat iedereen daadwerkelijk dienen moet, maar dat slechts een deel van de jongeren onder de wapenen komt. Door keuringen en het buitengewoon dienstplichtig stellen van groepen jongeren vallen veelal die groepen buiten de boot die het enerzijds nodig hebben om hun sociale achterstand te kunnen verbeteren, terwijl aan de andere kant de groep die voor de positieve leereffecten zou moeten zorgen veelal ook niet in aarmmerking komt voor de dienstplicht. In hoofdstuk 3 is dit proces nader geillustreerd aan de hand van een beschrijving van het systeem van plaatsvervanging in de negentiende eeuw. Hoewel door de algemene dienstplicht in Nederland grote groepen niet direct in zijn geheel buiten de dienstplicht vallen (zie tabel 2 van paragraaf 4.3.), is het aantal dienstplichtigen zo klein geworden dat van een echte algemene dienstplicht geen sprake is. Bovendien geven de cijfers in tabel 2 van paragraaf 4.3. geen inzicht in de verdeling van jongeren die niet in dienst zijn geweest over de opleidingen, zodat van de leereffecten op meso-economisch niveau op basis van deze tabel helemaail niets te zeggen is, als die er al mochten zijn onder het huidige systeem.

In Groot-Brittannie is er wel onderzoek gedaan naar de leereffecten op meso-economisch niveau, maar Mark Abrams komt niet verder dan de conclusie dat:

"But if conscription in Britain seemed to have had very little direct effect on the quality of education, itt apparantly affected modestly career choices-understandlably since deferment was based on occupation". 3

Met andere woorden door de vrijstellingen in het dienstplichtbeleid bewogen jongeren zich naar die beroepen die een vrijstelling opleverden en bleek het onderwijs om voor die beroepen in aanmerking te komen volop in de belangstelling te staan. De leereffecten door de dienstplicht ontstonden niet door het ondervinden van de dienstplicht, maar juist door het ontgaan van de dienstplicht, terwijl het ontgaan van de dienstplicht juist het gevolg was van het niet uitvoeren van een echte algemene dienstplicht.

Eenzelfde ontwikkeling was in de Verenigde Staten waar te nemen. Zo stelt Morris Janowitz dat:

"At the lower end of the educational continuum the incidence of military service declines sharply; only,
one-third of those with less than grammar school education served in the military. At the upper end of
the continum, those who entered graduate and professional school, similarly only one-quarter entered
active service. The reasons are obviously different. Those with less than eight years of education were
deferred on the basis of unfitness a direct expression of their low educational achievement and related

${ }^{3}$ Mark Abrams, Some Effect of British Military Service, in: Sol Tax, The Draft, blz, 176, Chicago 1967 
medical and psychiatric conditions. Graduate and professional study produced exemption on the basis of educational deferment, often supplemented by marital deferment. 4

Juist de groepen die een maatschappelijke achterstand hebben, zoals in de Verenigde Staten de negerbevolking, worden ook voor de dienstplicht buitengesloten. Zij worden afgekeurd, omdat het Ministerie van Defensie windt dat zij gezien de technologische ontwikkeling van de oorlogsvoering ongeschikt zijn voor de krijgsmacht. In feite botsen hier de belangen van de krijgsmacht en de belangen die de samenleving heeft op het gebied van scholing. Daar de krijgsmacht primair bedoeld is voor de bescherming van de bevolking en niet voor de scholing van de bevolking, is in vele landen, zoals Nederland en de Verenigde Staten van een echte algemene dienstplicht nooit sprake geweest. De leereffecten van de dienstplicht op meso-economisch niveau moeten voor Nederland daarom alleen al op basis van dit gegeven laag worden ingeschat.

Samengevat kunnen we stellen dat een noodzakelijke voorwaarde voor het bestaan van leereffecten door de dienstplicht op meso-economisch niveau het bestaan van een 'echte' algemene dienstplicht is, een dienstplicht waarin ook daadwerkelijk iedereen dient.

Dit wil echter niet zeggen dat de leereffecten ook daadwerkelijk aanwezig zijn als er een algemene dienstplicht is. Dit hangt ondermeer af van het bestaan van andere instituties die de rol van de dienstplicht op dit punt zouden kunnen overnemen. Het bestaan van alternatieve instituties speelt ook een belangrijke rol bij de analyse van de leereffecten door de dienstplicht op macro-economisch niveau. Voordat we de leereffecten door de dienstplicht op meso-economisch niveau in zijn geheel afronden, zullen we dan ook eerst de analyse op macro-economisch niveau bekijken en vervolgens tot een slotoordeel komen.

Bij een analyse naar de leereffecten van de dienstplicht op een macro-economisch niveau gaat het in feite om de analyse in hoeverre de samenleving in zijn geheel profiteert van de dienstplicht en dan riet zozeer door de bescherming van de grenzen van het land, maar door de afgeleide leereffecten van de dienstplicht. Wat deze afgeleide leereffecten nu precies inhouden zullen we illustreren aan de hand van de ontwikkeling van het moderne Duitsland in het algemeen en de ontwikkeling van de Staat Pruisen in het bijzonder. 5

Na de Dertig Jarige oorlog (1618-1648) was er van een echt Duitsland geen sprake meer. Het land was verdeeld in meer dan tweehonderd delen en was fén grote ruïne. Uit deze ruïnes kwamen langzaam de prinsen van de diverse staatjes naar voren als absolute vorsten en verdween de rol van het centrale rijk.

Barraclough schrijft over dit Duitsland: 6

After 1648 it was no longer an empire at all, and scarcely even a federation: it had no common treasury, no efficient common tribunals and no means of coercing a refactory member. (....) It was neither a limited monarchy, as imperialists writers vainly sought to prove, nor a federal state, since effective means of federall action were lacking, particularly in the sphere of war and foreign relations.

Het absolutisme van de vorsten rustte voornamelijk op twee pilaren, nl. de administratie en het leger, waarbij de vorsten moreel gesteund werden door de kerk. Vrijwel iedere staat in het Duitsland van de 17e eeuw voldeed aan dit profiel. Eigenlijk was

\footnotetext{
4Morris Janowitz, The Logic of National Service, in: Sol Tax, The Draft, blz. 77

${ }^{5}$ De wolgende passages zijn gebaseerd op het werk van: Geoffrey Barraclough, The Origins of Modem Germiany, Oxford, 1976 .

IIdem, blz. 383.
} 
het in Pruisen niet veel anders. In de verspreide gebieden die zich uitstrekten van delen bij de Rijn tot aan delen in het huidige Rusland:

(san.), there was no unity of common tradition; there was not; until the end of the eighteenth century, the unity of a common body of law; still less was there any common representative body; the one unity wass that of common body of administration and a Prussian army. ${ }^{\text {"7 }}$

Echter wat de geschiedenis van Pruisen anders maakte dan de geschiedenis van andere delen van Duitsland was niet zozeer de territoriale geschiedenis, die niet veranderde totdat Frederik de Grote in 1740 zijn aanval lanceerde op Oostenrijk, het was veeleer:

"(m...) the subordination of all inhabitants, from the king downwards, to the service of the State. (....) It was this sense of subordination to a higher duty, of responsibility to a higher power, which distinguished the Prussian state from the rest of eighteenth-century Germany. The famous doctrine that the prince is the servant of the state was a peculiarly Prussian doctrine. Its kings conscripted the lives of the peasants and the services of their nobles, but they also conscripted themselves." ${ }^{18}$

Terwijl de andere staten wegkwijnden onder een ouderwetse en verkwistende overheid, zette Pruisen het voorbeeld van een overheid, die sober streefde naar een ontwikkeling van alle produktiefactoren van het land; een zwaar gedisciplineerd leger, en een traditie ten aanzien van de dienstplicht die in bepaalde mate de plaats in nam van vrije politieke activiteiten alls bron van samenhang in de samenleving*

"(....) it remains true that the people of Prussia, under the constant pressure of royal precept and royal example, alone among the people of eighteenth-century Germany felt any sense of identity with the government set above them. It was a stern relationship, based on duty and obedience, on austerity and work; its substance was the obligation of every individual, low and exalted, rich and poor to serve the State with body and soul in life and death. "9

Van groot belang in deze ontwikkeling is de rol van de leider. De leider van de samenleving geeft in feite persoonlijk het belang van de dienstplicht aan. Frederik de Grote en zijn voorgangers moesten dit wel persoonlijk doen, omdat andere kanalen om dit bewerkstelligen in Pruisen toen nog niet bestonden of nog niet voldoende ontwikkeld waren. Hedentendage zouden we gebruik kunnen maken van de schoolplicht, terwijl we daarnaast de beschikking hebben over een groot arsenaal aan communicatiemiddelen om de gezamenlijke boodschap te verkondigen. In de achttiende eeuw waren deze instituties onvoldoende ontwikkeld en moest de koning zelf het voorbeeld geven aan de traditie van de dienstplicht. De grote kracht van Pruisen in deze was dat de dienstplicht zonder aanziens des persoons ging. Iedereen vervulde zijn plicht en omdat het leger en de administratie de enige instituties waren waarlangs deze plicht daadwerkelijk vervult kon worden, kreeg dit in de praktijk de vorm van de militaire dienstplicht.

In 1763 was Pruisen een Europese mogendheid, mede door de eenheid van het volk als gevolg van de dienstplicht. Deze eenheid werd weliswaar geintieerd door bedreigingen van buitenaf en de druk van een eventuele oorlog, maar door haar organisatie deze dreigingen te voorkomen, werd Pruisen een echte eenheid en door alle leereffecten die daarmee samenhingen tevens een grote mogendheid.

\footnotetext{
$7_{\text {Idem, biz } 399 .}$

${ }^{8}$ Idem, ble. 398-399.

${ }^{9}$ Idem, batz. 399.
} 
"The rise of Prussia to the rank of a great power modified the whole European constellation, and laid the foundation for the reconstruction of Germany after the French Revolution and the Napoleonic Wars had overtrown the old order and brought about a basic territorial simplification. Its emergence as a European power would have been impossible without the work of internal consolidation to which Frederick William I and Frederick the Great directed their energies ${ }^{\mathrm{m}}$. 10

Uit dit citaat blijkt niet alleen de grootsheid van Pruisen, maar dat Pruisen niet onoverwinnelijk was geworden. Reeds in 1763 schakelde Pruisen over van een dienstplichtigenleger naar een vrijwilligersleger. Met deze overstap ging ook de traditie van de dienstplicht verloren. Een traditie die verder een flinke knauw had gekregen door het overlijden van Frederik de Grote in 1786.

$\mathrm{Na}$ de Napoleontische oorlogen keerde Pruisen onder leiding van Scharnhorst, Hardenberg en Stein dan ook snel terug naar het dienstplichtigenleger. Zij realiseerden zich dat het vrijwel onmogelijk was Pruisen wit het dal te halen waarin het zich in 1806 bevond zonder de staat politiek te hervormen en de steun van de bevolking terug te winnen zonder deze bevolking in dit veranderingsproces te betrekken. Met het verdwijnen van de algemene dienstplicht in 1763 was ook de eenheid van de staat verdwenen, terwijl de rol van de dienstplicht niet was overgenomen door andere instituties, zoals scholing en communicatie.

Uit de analyse van de ontwikkeling van Pruisen blijkt dat er speciale voorwaarden moeten zijn wil de dienstplicht duidelijke leereffecten met zich meebrengen voor de gehele samenleving. Indien we iets willen zeggen over de leereffecten van de dienstplicht op meso-economisch en macro-economisch niveau dienen we ons voor ogen te houden dat 'echte' algemene dienstplicht een absoluut noodzakelijk voorwaarde is, will er sowieso sprake zijn van leereffecten, terwijl de opbrengsten van de dienstplicht als gevolg van de leereffecten op beide niveau's laag dienen te worden ingeschat, indien er goede alternatieven zijn waarmee hetzelfde bereikt kan worden, zoals de schoolplicht. Welke nu in onze tijd gekozen moet worden, dienstplicht of schoolplicht, zal in het slot van dit hoofdstuk naar voren worden gebracht aan de hand van een kosten-baten analyse. Hier zullen we slechts opmerken dat als schoolplicht maatschappelijker goedkoper is dan dienstplicht, de extra leereffecten van de dienstplicht te verwaarlozen zijin.

Uit de geschiedenis van Pruisen en de ontwikkeling van het dienstplichtigenleger in Nederland en in de Verenigde Staten is in leder geval duidelijk geworden dat:

\footnotetext{
"An effective citizin army required (and requires) very special conditions to flourish. First, the technical level of warfare must be such that no elaborate or expensive equipment that is beyond the reach of or dinary citizens can have decisive effect in battle (....) In the second place, a citizen army can only be effective as long as most citizens trust one another enough to fight side by side and back to back-not face to face against one another"11,
}

waar de auteur van dit citaat, William H. McNeill, an toevoegt dat in een vrijwilligersleger zeer goed moet worden nagedacht over de wijze waarop de leiding van een samenleving gekoppeld wordt aan de militaire leiding, wil dit niet tegen de samenleving werken:

\footnotetext{
10 Tdem, blz. 399.

11William H. MeNeil, The Draft in the Light of History; in: Sol Tax, The Draft, hoofdstuk 12, bly 118.
} 
"If the United States decides nevertheless to accept the risks of relying upon long-term-service professional troops of the sort suited for conducting distant, low-grade wars and for garrison duty overseas, then devices must be found for linking military leadership more closely with the leadership of civil society. The existing policy of exempting the future leaders of civilian life from military service positively invites divergence of view point and seems almost suicidal in a democracy."12

\section{\$9.3. Sociale dienstplicht: de uitvoerbaarheid}

De uitvoering van de sociale dienstplicht is een politieke keuze. Voor deze keuze is het noodzakelijk dat de kosten en baten van de sociale dienstplicht duidelijk tegenover elkaar worden gezet. Hoewel het moeilijk is dit exact uit te voeren, zullen we in deze paragraaf daartoe toch een poging wagen. We zullen eerst de positieve kanten van de sociale dienstplicht onder de loep nemen, zoals deze zijn verwoord in paragraaf 9.1. ten einde te kunnen zien of deze argumenten door de bevindingen in paragraaf 9.2. niet in waarde veranderd zijn.

Uitgangspunt voor de sociale dienstplicht is dat iedereen zich naar vermogen dient in te zetten voor de maatschappij. Wat dient nu te worden verstaan onder de maatschappij. In dit proefschrift is in hoofdstuk 1 uitgegaan van de veronderstelling dat de maatschappij een gemeenschap van mensen is. De mensen in deze gemeenschap roepen de hulp van een overheid in om voor die goederen te zorgen waar zij als individueel persoon niet aan toe kunnen komen. De overheid is dus ondergeschikt aan de burgers in een gemeenschap, en dient zich te richten naar de wensen van deze gemeenschap. In ruil voor de voorzieningen betalen de burgers belasting. Deze belasting wordt in een aantal gevallen naar draagkracht geheven, waardoor een ieder zich naar vermogen inzet voor deze maatschappij. Of de belasting in-natura of in geld wordt betaald doet hier niet ter zake, in beide gevallen is er sprake van een bijdrage aan de maatschappij. Een belasting-in-natura kan daarbij worden omgerekend in geld, indien bekend is wat de waarde van de belasting-in-natura is.

Hieruit volgt dat door het inzetten van sociale dienstplichtigen geen belastingbesparingen voor de maatschappij gerealiseerd kurnen worden. De introductie van sociale dienstplicht betekent de introductie van een belasting-in-natura, terwijl de financiering ook geregeld had kunnen worden door de introductie van een belasting in geld.

Indien de maatschappiy taken laat liggen, omdat zij daar geen geld voor over heeft, kan het dus niet zo zijn dat de sociale dienstplicht daar nu wel de ruimte voor schept. De kosten voor deze taken zijn immers niet veranderd, ze hebben hoogstens een ander jasje gekregen. Een eventuele invoering van de sociale dienstplicht komt dus voort uit een andere prioriteitenafweging, die daarvoor niet is gemaakt. We zouden ook kunnen zeggen dat de aanhangers van sociale dienstplicht met behulp van de sociale dienstplicht die maatschappelijke voorzieningen tot stand willen brengen, die op basis van een normale prioriteitenafweging niet tot stand komen, omdat anderen deze voorzieningen niet belangrijk vinden.

Vaak wordt gesteld dat sociale dienstplichtigen moeten worden ingezet om taken te vervullen die maatschappelijk belangrijk zijn. Toch zijn deze taken maatschappelijk blijkbaar niet $z o$ belangrijk, anders waren zij er op normale wijze wel gekomen. Het zelfde geldt voor het vuile en onaangename werk. Indien gevonden wordt dat dit

${ }^{12}$ Idem. 
werk gedaan moet worden, dan moeten we dit werk ook belonen, door er de juiste prioriteiten aan toe te kennen. Indien de prioriteiten niet bestaan, omdat het produkt waarvoor vuil en onaangenaam werk moet worden verricht niet belangrijk genoeg wordt gevonden, zal het produkt niet worden geproduceerd, of met andere woorden blijft het vuile en onaangename werk liggen.

Het vierde punt dat wordt aangevoerd is de kwestie van de gelijkberechtiging; Alle jongeren dienen werk te verrichten voor de maatschappij, in plaats van slechts een gering aantal jongeren, zoals bij de militaire dienstplicht. Sociale dienstplicht kan inderdaad leiden tot een gelijkberechtiging van alle jongeren, maar dan is het noodzakelijk dat alle jongeren inderdaad dienen en er geen enkele uitzonderingssituatie bestaat. Er moet sprake zijn van een "echte" algemene dienstplicht. Dit betekent ondermeer dat jongeren niet gekeurd moeten worden, want door een keuring zullen er jongeren afgekeurd worden voor socialle dienstplicht, waardoor de gelijkberechtiging doorbroken wordt.

Op het eerste gezicht lijkt het nogal vreemd jongeren niet te keuren. Jongeren met verschillende handicaps zijn niet geschikt voor velerlei soorten functies, en zouden beter afgekeurd kunnen worden. Op korte termijn lijkt het dat een vrijstelling van bepaalde groepen gerechtvaardigd is, maar op lange termijn liggen de zaken toch weer anders.

Door de uitzonderingssituaties kan een ontwijkingsgedrag opkomen. Daarnaast is het zo dat de keuringscriteria ook niet waardevrij op te stellen zijn. Dit heeft ondermeer te maken met het oneindige aanbod van arbeidskrachten dat de sociale dienstplicht meebrengt. Aan een boom zo vol geladen, missen we én, twee pruimpjes niet, waardoor keuringsartsen de neiging kunnen krijgen twijfelgevallen toch maar af te keuren, omdat de vervanger toch al klaar staat. Bij de militaire dienstplicht heeft dit. proces geresulteerd in een situatie, waar zo"n $27 \%$ van de jongeren wordt afgekeurd, terwijl met de meeste jongeren toch weinig aan de hand is. De krijgsmacht heeft graag het neusje van de zalm, die zij door het "oneindige" aanbod gemakkelijk kan bereiken. 13

Een zelfde opmerking geldt ook voor het uitvoeringsmechanisme waardoor de sociale dienstplicht vorm gegeven zou moeten worden. Op korte termijn zijn de kosten van uitvoering beperkt en te overzien, zoals door Charles Moskos is weergegeven in zijn boek "A call to civil Service". Doch met de invoering van de sociale dienstplicht verdwijnen de corrigerende, onzichtbare prikkels van het marktmechanisme en heeft ook het uitvoeringsmechanisme de neiging uit te groeien tot een bureaucratisch moloch van de eerste orde.

Met betrekking tot het laatste punt dat in de discussie over sociale dienstplicht naar voren komt, de vermindering van de werkloosheid, zullen we herhalen wat we eerder in paragraaf 9.2. hebben gezegd. Het effect op de werkloosheid is diffuus, doordat verschillende substitutie-en afwentelingsprocessen elkaar tegenwerken.

Indien we alles tegenover elkaar zetten blijkt dat een heleboel argumenten voor de sociale dienstplicht wegvallen en dat het vraagstuk van de sociale dienstplicht een afweging is van de kennis die de jongeren door de sociale dienstplicht verkrijgen tegenover de "excess burden" die de sociale dienstplicht met zich meebrengt.

Indien de meerwaarde van de kennis," die van de "excess -burden" overtreft dan is de keuze voor sociale dienstplicht gerechtvaardigd. Hoe groot belde elementen in geld uitgedrukt zijn is moeilijk te zeggen, doch met behulp van de gegevens verkregen uit

13 Zie voor dit mechanisme paragraaf 6.3. over het wervings en selectieproces ir de krijgsmacht, gn de fouteri van de erste en de tweede scoort die bij dit proces komen kijken onder dienstplicht en onder vrijwillighteid. 
de analyse van de millitaire dienstplicht kunnen we een schatting maken. De "excess burden" van de militaire dienstplicht bedraagt ongeveer 2 miljard gulden per jaar, zoals blijkt uht paragraaf 5.7. Bij de sociale dienstplicht zijn 5 mal zoveel mensen in het spel. Door extrapolatie van het bedrag van de "excess-burden" bij de militaire dienstplicht naar de sociale dienstplicht en komen we op een bedrag van 10 miljard gulden per jaar voor de "excess-burden" bij de sociale dienstplicht.

De meerwaarde van de kennis voor de dienstplichtigen is ongeveer nul, zoals we in de vorige paragraaf zagen. Dit gegeven komt van de dienstplichtigen zelf. De directe omgeving kan echter vaak beter beoordelen of de kennis van de dienstplichtigen verbeterd is.

Toch is het maar de vraag of de verbreding van de kennis van de maatschappij door de jongeren, de prijs van de "excess-burden", die hier is geschat op 10 milljard gulden per jaar, waard is. Naar alle waarschijnlijkheid is het veel goedkoper jongeren de ontbrekende kennis over de maatschappij en het functioneren in deze maatschappij bij te brengen via het onderwijssysteem. Dan praten we niet meer over de sociale dienstplicht, maar over een uitbreiding van de schoolplicht.

De schoolplicht komt onder meer voort uit de gedachte jongeren voor te bereiden op een plaats in de matschappij en te voorkomen dat jongeren onvoldoende voorbereid in die matschappij terecht komen, omdat zij overhaaste beslissingen nemen. Beslissingen waar zij gezien hun leeftijd eigenlijk nog niet aan toe zijn om deze op een juiste wijze te nemen. Achter de reden van de schoolplicht schuilt ook de "opportunity costs" gedachte. Met de schoolplicht wordt getracht te voorkomen dat lemand te vroeg met het leerproces stopt, waardoor zijn toekomstige mogelijkheden te sterk worden beperkt. Voor ieder persoon zijn de "opportunity costs" echter verschillend. Vele jongeren zijn van mening dat zij met het bereiken van de leerplichtige leeftijd van 15 jaar onvoldoende kennis hebben opgebouwd om hier mee de maatschappij in te gaan. Zij gaan door met leren ten einde hun toekomstige mogelijkheden verder uit te breiden. Aan de andere kant leidt de schoolplicht ook tot verspilling. De verveling op scholen is hiervan een duidelijk voorbeeld. Hoewel veel jongeren bij het bereiken van de leerplichtige leeftijd verder studeren en niet beschikbaar zijn voor de arbeidsmarkt, leidt de schoolplicht tot een verkrapping van de arbeidsmarkt, omdat de jongeren die worden gehinderd door de leerplicht daar nu niet terecht kunnen.

Belangrijk voordeel van de schoolplicht boven de sociale dienstplicht is dat de schoolplicht niet ingrijpt in de markten voor produktiefactoren en dus niet leidt tot de uitschakeling van het marktmechanisme in deze markten. Juist door dit voordeel zal de "excess burden" van de schoolplicht lager zijn dan de "excess burden" van de dienstplicht, waarmee de globale kosten-baten analyse in ieder geval in het nadeel uitvalt voor de dienstplicht. Dit is dan ook mede de reden in de eerdere hoofdstukken over de militaire dienstplicht vrijwel geen aandacht te besteden aan de leereffecten van de dienstplicht op meso-economisch en macro-economisch niveau. Deze opbrengsten zijn in de huidige omstandigheden te gering om een essentieel onderdeel van de analyse uit te maken.

\section{\$9.4. Conclusies}

In dit hoofdstuk is gekeken naar de sociale dienstplicht. In de eerste paragraaf is sociale dienstplicht gedefinieerd als: 
"Gedurende een bepaalde periode verplicht verichten van werkzaamheden, waaraan aantoonbare maatschappelijke behoeften bestaan".

Deze behoefte komt voort wit de algemene behoeften van de maatschappij. ledere behoefte wordt echter beperkt door de mogelijkheden die er zijn. Dit geldt zowel voor private als voor collectieve goederen. Of de behoeften van de maatschappij daadwerkelijk vervuld worden hangt af van de prioriteiten die de maatschappij stelt. Op basis van de prioriteitenstelling worden activiteiten ondernomen on de behoeften te bevredigen. Er worden met andere woorden private en collectieve goederen geproduceerd. Voor de produktie van deze goederen worden produktiefactoren gebruikt. Deze produktiefactoren komen voort uit de maatschappij, waar zij schaars en alternatief aanwendbaar zijn. Andere goederen zullen op basis van de prioriteitenstelling niet geproduceerd worden, omdat zij blijkbaar niet belangrijk genoeg worden geacht.

Gezien de definitie van sociale dienstplicht richt de sociale dienstplicht zich vooral op die goederen die bij een normale prioriteitenstelling niet tot stand komen. Waren zij wel tot stand gekomen, dan had de maatschappij daar geen behoefte aan gehad. Met behulp van de sociale dienstplicht wordt geprobeerd de prioriteitenstelling ten aanzien van de te besteden gelden in de maatschappij te wijzigen. De kosten van de sociale dienstplicht gaan echter de baten ver te boven, omdat sociale dienstplicht niet leidt tot een kostenvermindering woor de maatschappij, maar slechts tot een verschuiving van lasten van oud naar jong, van zichtbare kosten naar onzichtbare kosten. en van een belasting in geld naar een belasting in natura. De totale lasten blijven echter voortdurend gelijk, indien geen rekening wordt gehouden met de "excess -burden" van de sociale dienstplicht. Wordt de "excess-burden" wel in het verhaal betrokken, dam zullen de maatschappelijke kosten verder stijgen.

De "excess-burden" ontstaat door de uitschakeling van marktmechanisme in de markten voor produktiefactoren. Door de uitschakeling van het marktmechanisme krijgen de sectoren, waat de sociale dienstplicht wordt ingevoerd, geen prikkels meer die kunnen leiden tot een efficiënte produktie van de goederen, waar deze sectoren voor dienen te zorgen. Op korte termijn is van de inefficiëntie weinig te zien, doch op lange termijn zal het gemis aan automatische prikkels onherroepelijk boven water komen en zullen de lasten navenant toenemen.

Sociale dienstplicht laat zich dan ook goed vergelijken met een computerprogramma met het Pac-Man-virus. In eerste instantie zorgt het computerprogramma voor een voortreffelijke bestand aan gegevens, maar met de vervolmaking van het bestand wordt het Pac-Man-virus in werking gesteld, welke langzaam de "bits" en "bites" van het programma opeet, waardoor het bestand na verloop van tijd wordt vernietigd en de bezitter van het bestand helemaal opnieuw kan beginnen met een ander computerprogramma. Sociale dienstplicht lijkt op korte termijn heel aardig, maar tast langzaam maar zeker de fundamenten van het marktmechanisme aan, waardoor de produktie van de sector waar de social dienstplichtigen werken na verloop van tijd als een kaartenhuis in elkaar zakt.

Sociale dienstplicht kan nooit waar maken, wat militaire dienstplicht en schoolplicht wel kunnen klaarmaken, en dat is dat de "opportunity costs" van de arbeid die onder de plicht valt onder sociale dierstplicht nooit boven haar marktwaarde kan stijgen. Bij militaire dienstplicht is dit wel mogelijk in het geval van een invasie. Terwijl bij de schoolplicht de "opportunity winst" vooral ligt in de toekomstige waarde van de arbeid. Sociale dienstplicht is dan ook niets anders dan via een dure, bureaucratische en kortzichtige omweg de produktie van die voorzieningen reali- 
seren, die onder een normaal democratisch besluitvormüngsproces niet tot stand zijn gekomen. 


\section{Samenvatting en conclusies}

Dit proefschrift begint met een uitspraak van Lionel Robbins.. Hij stelt dat: "Bconomics is the science which studies human behavior as a relationship between ends and scarce means which have alternative uses". Ook voor de militaire dienstplicht gaat deze stellling op.

Militaire dienstplicht is een vorm van economische politiek om de kosten van arbeid in de krijgsmacht laag te houden. De economische kosten van dienstplicht komen zonder meer naar voren wanneer de alternatieve kosten van dienstplicht aan het licht komen. Indien dienstplichtigen de vrije keuze hadden gehad om in dienst van de krijgsmacht te treden, dan hadden velen dit onder de huidige omstandigheden niet gedaan, omdat voor velen de kosten van de dienstplicht de baten in grote mate overschrijden.

In de economische wetenschappen hebben de"opportunity costs" in vragen over oorlogvoering voortdurend centraal gestaan. Dit was al zo in het werk van Adam Smith uit 1776 en is in feite nog steeds zo.

Anno 1993 bestaat de dienstplicht nog steeds, hoewel reeds beslist is om de dienstplicht per 1 januari 1998 definitief ten grave te dragen door de laatste dienstplichtige naar huis te sturen en te vervangen door vrijwillige militairen. Dit proefschrift analyseert de economische aspecten van de personeelscomponent in de krijgsmacht door de kosten van de dienstplicht voor de maatschappij te analyseren en de resultaten van deze analyse te gebruiken voor de opzet van het vrijwilligersleger dat het dienstplichtigenleger in 1998 moet opvolgen.

Het eerste hoofdstuk van dit proefschrift concentreert zich op de bouwstenen van het onderzoek. Eén van de bouwstenen is de welvaartseconomie. De welvaartsecom nomie is een economische theorie over de wenselijkheid van alternatieve economische situaties, zoals een dienstplichtigenleger of een vrijwilligersleger. In de welvalartseconomie wordt uitgegaan van een mechanische visie op de staat, dat wil zeggen dat het individu in de samenleving in het middelpunt van de belangstelling staat en niet de staat. Vertaald naar de militaire dienstplicht will dit zeggen dat naast het welzijn van de algemene belastingbetaler, de bestuurder, de militair etc, het welzijn of de welvaart van de dienstplichtige een belangrijke rol speelt bij de analyse naar de economische aspecten van de militaire dienstplicht. Bij deze analyse staat het concept van de "opportunity-costs" van de dienstplichtige dan ook centraal, omdat op deze wijze op een juiste wijze de welvaartsaspecten van de militaire dienstplicht voor alle soorten individuen en de krijgsmacht in kaart kunnen worden gebracht. Daar komt bij dat het welvaartsconcept zich niet alleen concentreert op de sociale kosten van de dienstplichtigen, maar ook op de afwezigheid van schaarste aan arbeidskrachten door de plicht. De economische wetenschap kan namelijk in deze aandragen hoe de situatie 
in de krijgsmacht had kurmen zijn, indien er binnen de krijgsmacht een situatie wan schaarste, de alternatieve situatie, had bestaan.

Dienstplichtigen worden ingezet in de krijgsmacht, die dient te zorgen voor de voortbrenging van het collectieve goed defensie. Hoofdstuk 2 gaat verder met de produktie van het collectieve goed defensie, waarbij zij tevens een blik werpt op de actoren die voor de voortbrenging van het collectieve goed defensie noodzakelijk zijn.

Defensie is een collectief goed, omdat het onmogelijk is om degenen die niet willen betalen uit te sluiten van het collectieve goed defensie. Daamaast zullen de aanspraken van éen persoon op het collectieve goed defensie, niet ten koste gaan van de aanspraken van een ander persoon op datzelfde goed. Non-exclusiviteit en non-rivaliteit van het collectieve goed defensie zorgen ervoor dat de overheid de financiering van defensie ter hand neemt door middel van belastingheffing. Indien collectieve goederen collectief gefinancierd worden, betekent dit nog niet dat zij door de overheid geproduceerd moeten worden. In het geval van defensie neemt de overheid de produktie wel ter hand. Dit heeft te maken met het geweldsmonopolie dat de overheid heeft. Toch betekent het bezit van het geweldsmonopolie niet dat de krijgsmacht, als producent van gevechtskracht, de economische wetten ten aanzien van de produktie ter zijde kan schuiven. Aanwending van produktiemiddelen in de defensiesector houdt een onttrekking van middelen in de civiele maatschappij in, waar deze middelen relatief schaars zijn ten opzichte van de daar voorkomende behoeften.

De aanwezigheid van het geweldsmonopolie voor de krijgsmacht betekent niet dat alle mensen werkzaam in de krijgsmacht ook militairen dienen te zijn. De krijgsmacht kent gevechtsfuncties, waarbij het gebruiken van geweld voorop staat, en nietgevechtsfuncties. Bij deze laatste functies stat de ondersteuning van de gevechtseenheden centraal zonder dat deze eenheden zelf gebruik van geweld zullen maken. Dit laatste betekent dat deze taken ook door burgers kunnen worden uitgevoerd, mits deze burgers goedkoper zijn dan de militairen. Uit hoofdstuk 5 blijkt dat dit inderdaad het geval is.

Bij het vullen van de gevechtsfuncties staat de samenleving de keuze open tussen een vrijwilligersleger en een dienstplichtigenleger. Bij een vrijwilligersleger worden de soldaten op vrijwillige basis aangetrokken, en worden de salarissen van de soldaten betaald uit de belastingopbrengsten. In een dienstplichtigenleger staat de plicht voorop. De dienstplichtigen krijgen een salaris, wedde, welke lager is dan het inkomen dat zij in de burgerma tschappij hadden kumnen verdienen, indien zij niet onder de plicht waren gevallen. Met andere woorden de dienstplichtigen betalen een belasting-in-nativa (hoofdstuk 4). De last van de dienstplicht, of de dienstplichtbelasting wordt gekarakteriseerd door het verschil tussen de wedde en de "opportunity costs" van een dienstplichtige. De "opportunity costs" van een dienstplichtige zijin daarbij gelijk aan de som van zijn alternatieve burgerloon en de "baalpremie" als gevolg van het missen van niet-geldelijke voordelen in de burgermatschappij.

De dienstplichtbelasting in Nederland bedraagt ongeveer 10.000 gulden per dienstplichtige per jaar, zonder dat rekening is gehouden met de kosten voor een dienstplichtige welke optreden na het verstrijken van de dienstplichttijd als gevolg van een verlies a an ervaringsjaren. De dienstplichtbelasting is niet terug te vinden in de cijfers voor de collectieve lastendruk in Nederland. Een vreemde situatie daar we in Nederland in allerlei vormen rekening houden met de lasten die de samenleving aan haar burgers oplegt in normen als de collectieve lastendruk.

De dienstplichtbellasting zorgt naast een grote hoeveelheid inningskosten ook voor een relatieve verandering van de factorprijzen van produktiefactoren in de 
krijgsmacht (hoofdstuk 5). Dienstplicht maakt arbeid goedkoop, en dit zorgt voor een situatie waarin de krijgsmacht het collectieve goed defensie voortbrengt met een grotere hoeveelheid arbeid, militairen en onervaren krachten dan noodzakelijk is. Dienstplicht verhult de werkelijke kosten in de krijgsmacht en zorgt op deze wijze voor een "excess-burden" ter grootte van zo'n 2,1 miljard gulden per jaar, omdat door de dienstplicht de substitutie van arbeid naar kapitaal, militaire arbeid naar burgerarbeid, en van onervaren krachten naar ervaren krachten achterwege blijft. Bovendien leidt de misallocatie als gevolg van het dienstplichtsysteem tot een grote mate van verveling en verwaarlozing van de primaire levensbehoeften van soldaten. Dienstplichtigen worden immers gedwongen om dienst te nemen in de krijgsmacht en kunnen geen ontslag nemen, indien hun de situatie in de krijgsmacht niet meer bevalt.

De uitwassen van het dienstplichtsysteem zijn niet alleen anno 1993 waarneembaar, ook in de $19 \mathrm{e}$ eeuw bleek de dienstplicht grote invloed te hebben op het maatschappelijk leven (hoofdstuk 3). In economisch opzicht is het kenmerkende element van de dienstplicht in de 19e eeuw het systeem van plaatsvervanging. Voor een bedrag dat bepaald werd door vraag en aanbod kon de rijkere man zich laten vervangen door iemand anders. Voor velen was het optreden als plaatsvervanger voordeliger dan zich als vrijwilliger aan te melden bij de krijgsmacht, omdat een plaatsvervanger een beloning kreeg welke in de richting kwam van de "opportunity costs" van de rijke man die hij moest vervangen, terwijl de plaatsvervanger als vrijwilliger slechts een beloning kon verwachten welke in de buurt zou komen van zijn eigen "opportunity costs". Door het systeem van plaatsvervanging was het praktisch onmogelijk geworden het door Napoleon ingevoerde, en door Koning Willem I uitgevoerde, dienstplichtsysteem te vervangen door een vrijwilligersleger. Hierbij is nog afgezien van het feit dat de krijgsmacht in de 19e eeuw absoluut niet kon concurreren met de burgermaatschappij als het ging om de werving van arbeidskrachten. Aan verzorging en huisvesting werd weinig aandacht besteed, de premie die de soldaat als vrijwilliger kreeg was te laag en zijn vooruitzichten voor de toekomst waren bedroevend.

Sinds de invoering van de dienstplicht in Nederland in 1815 is de dienstplicht nooit een vaststaand gegeven geweest. Dit geldt zowel voor Nederland, als ook voor vele andere landen in de wereld. Een uitgebreide discussie over de dienstplicht is ondermeer gevoerd in 1971 in de Verenigde Staten. Dit resulteerde uiteindelijk in hoofdzaak in eén aanbeveling: verhoog de wedde van dienstplichtigen tot dat niveau, waarbij het denkbaar is dat de krijgsmacht zich kan vullen met vrijwilligers. Dit geeft tén van de essentiële onderdelen van de vorming van een vrijwilligersleger weer. Om tot een vrijwilligersleger te komen dient de krijgsmacht te concurreren met de arbeidsvoorwaarden en arbeidsomstandigheden in de burgermaatschappij.

Bij de vergelijking van de krijgsmacht met de burgermaatschappij op het gebied van de arbeidsvoorwaarden en arbeidsomstandigheden komen de aspecten van de dienstplichtbelasting weer volledig in het daglicht te staan (hoofdstuk 6). Dienstplicht is een last voor de dienstplichtigen, maar een subsidie op arbeid voor de krijgsmacht. Deze subsidie komt op allerlei terreinen in de krijgsmacht naar voren. In de krijgs" macht is relatief veel zwaar en smerig werk, en worden veel taken niet door machines uitgevoerd, omdat arbeid door de dienstplicht kunstmatig goedkoop is gehouden en bovendien niet schaars is.

Het werven van vrijwilligers is dus meer dan het alleen maar bieden van een hoger salaris. Afgezien van het feit dat het bieden van een hoger salaris voor vrijwillige soldaten zijn weerslag zal vinden in het loongebouw van de gehele krijgsmacht, is het veel beter zich te richten op de secundaire arbeidsvoorwaarden, zoals scholing 
en een verbetering van de arbeidsomstandigheden. Zaken die zijn verwaarloosd in de krijgsmacht door het bestaan van de dienstplicht.

Goed beschouwd zal er in een wrijwilligersleger sprake moeten zijn van twee soorten contracten. Naast thet gewone geschreven contract zal er ook een ongeschreven contract moeten zijn, waarin de krijgsmacht zich heeft verplicht de militair te respecteren als een persoon, de militair nuttig werk te geven en mogelijkheid tot individuele ontplooing volledig tot uiting te laten komen. De militair heeft zich in het ongeschreven contract verplicht tot het zo goed mogelijk uitoefenen van zijn taak en gedisciplineerd gedrag.

De taak van de militair zall in de toekomst een andere zijin dan voor de val van de Berlijnse muur in 1989. Met het einde van de Koude Oorlog zijn de taken van de krijgsmacht veranderd. Naast haar Navo-hoofdtaak, zall inzet van troepen in VN-verband in de toekomst én van de belangrijkste taken van de Nederlandse krijgsmacht worden. Voor de militair betekent dit dat zijn taak niet alleen gericht zal zijn op het voortbrengen van pure gevechtskracht. De toekomstige militair zal in zijn opleidingsfase bovendien een mentaliteit moeten verwerven die gericht is op bemiddeling, verzoening en onderhandeling, terwijl voor het uitoefenen van humanitaire taken een gedegen civiele opleiding noodzakelijk is. Een civiele opleiding die verzorgd zal moeten worden door de krijgsmacht, waarmee zij tevens een positieve impuls geeft aan de a antrekkelijkheid van het militaire beroep zonder dat daarvoor de salarissen verhoogd hoeven worden.

De nieuwe taken van de krijgsmacht geven bovendien weer dat gevechtskracht niet alleen maar een combinatie is van kapitaal en arbeid, maar onder de nieuwe omstandigheden vooral gezien moet worden als een combinatie van kapitaal, arbeid en human capital.

In een vrijwilligersleger behoort het wervings- en selectieproces tot de essentiële pijlers van het systeem. In tegenstelling tot het dienstplichtigenleger is arbeid in een vrijwilligersleger schaars, en zullen potentiële vrijwilligers met de grootste zorgvuldigheid behandeld moeten worden. Mocht het aanbod van geschikte vrijwilligers achter blijven bij de behoefte wan de krijgsmacht, dan zal eerst gekeken moeten worden of dit niet veroorzaakt wordt door het stellen van te hoge selectie-eisen. Zo laten projecten uit de Verenigde Staten zien dat vrijwilligers die eerst waren afgewezen op mentale gronden, toch bevredigend konden functioneren in de krijgsmacht, indien de krijgsmacht deze mensen gewoon een kans gaf. Daarmaast laten de, deels onbedoelde, experimenten in de Verenigde Staten zien dat het stellen van classificatiegrenzen vooral een subjectieve, psychologische en arbitraire zaak is. Is de geschiktheid van de soldaat bekend volgens het classificatiesysteem, dan is het commentaar door commandanten valk niet van de lucht. Is de commandant niet op de hoogte van de geschiktheid van zijn personeel of geven we hem onjuiste informatie over deze geschiktheid, dan smelt het commentaar als sneeuw voor de zon, omdat in de praktijk blijkt dat volgens classificatiesystemen ongeschikte mensen toch heel geschikt kunnen zijn. Niet alleen kost het stellen van hoge selectiegrenzen veel geld in termen van extra salaris en extra wervingskosten, hoge selectiegrenzen brengen daarnaast hoge sociale kosten met zich mee, omdat geschikte mensen niet aan een baan worden geholpen.

In een vrijwilligersleger dient het aanbod van potentiële vrijwiligers zo groot mogelijk te worden grehouden. Dit betekent dat de vrouw in de krijgsmacht in thet middelpunt van de belangstelling zal moeten staan. Zonder een voldoende integratie van de vrouw in de krijgsmacht zal een vrijwilligersleger nooit efficiënt kunnen zijn, omdat een voldoende aanbod van vrouwen het arbeidsaanbod vergroot, waardoor de 
salariskosten voor vrijwilligers relatief laag gehouden kunnen worden. Eigenlijk is de integratie van de vrouw in de krijgsmacht geen vraagstuk dat handelt over de vtouw op zich, maar een vraagstuk dat zich richt op de fysiek zwakke mens in de krijgsmacht. Het is niet het onderscheid tussen mannen en vrouwen dat hier speelt, maar tussen sterke en minder sterke mensen. Waar de selectiegrenzen dan getrokken moeten worden is vervolgens een politieke vraag, gelijk aan de vraag: "Waar trekken we de grenzen in het classificatiesysteem".

De integratie van de fysiek zwakke mens is bovenal een vraagstuk van maatwerk. Op welke plaatsen kan zo'n militair op de juiste wijze worden ingezet, zonder dat op zo'n arbeidsplaats veel fysieke kracht nodig is. Vrijwel alle riet-gevechtsfuncties voldoen aan dit profiel ${ }_{n}$ terwijl voor vele gevechtsfuncties ook niet meer nodig is dan een druk op een knop, een computer, of een hydraulische installatie. Ook zal de ergonomie kunnen bijdragen ook het maatwerk. Het vraagstuk van ergonomische investeringen ten behoeve van de fysiek zwakke mens in een vrijwilligersleger zal voor de krijgsmacht een relatief nieuw verschijnsel zijn, omdat in een dienstplichtigenleger deze vraag niet actueel was, gezien de nimmer aflatende toevloed van dienstplichtigen in een dienstplichtigenleger.

Misschien nog wel belangrijker dan het zo groot mogelijk houden van het arbeidsaanbod van vrijwilligers, is het beperkt houden van de vraag naar nieuwe vrijwilligers. In hoofdstuk 5 wordt naar voren gebracht dat de vraag naar militairen zo groot is, omdat de kosten verbonden aan het gebruik van militairen zo laag zijn. Een grote vraag veroorzaakt door het bestaan van de dienstplicht. Indien de werkelijke kosten van militairen betaald moeten worden, is een vermindering van de vraag naar militairen te verwachten, geinitieerd door substitutieprocessen van arbeid naar kapitaal, van militairen naar burgers en van onervaren naar ervaren militairen. Het gaat hier primair om een vermindering van de vraag als gevolg van een confrontatie van de krijgsmacht met de werkelijke kosten van het gebruik van produktiefactoren.

De vraag naar militairen kan bovendien op een aantal andere manieren verminderd worden. Zo heeft de krijgsmacht altijd haar zinnen gezet op een "jonge en krachtige" krijgsmacht. Een jonge krijgsmacht betekent echter ook een onervaren krijgsmacht, terwijl het fysieke element in de toekomstige krijgsmacht juist van minder belang is. Voor de traditionele taken van de krijgsmacht staat vooral de kapitaalscomponent in de gevechtskracht voorop, terwijl voor VN-taken het element van human capital de belangrijkste produktiefactor zal zijn. Slechts voor een klein aantal functies, bijvoorbeeld bij de infanterie, de commando"s en de mariniers, zal het fysieke element voorop blijven staan.

Ook het "up-or-out" systeem zorgt voor een "jonge" krijgsmacht. Daar de hiërarchische militaire organisatie aan de top steeds smaller wordt, zorgt een opwaartse stroming door de organisatie voor de situatie dat ervaren mensen de organisatie moeten verlaten en vervangen worden door onervaren mensen. Dit gebeurt simpelweg omdat in rang niet meer omhoog gegaan kan worden.

In een vrijwilligersleger werkt deze wijze van personeelsmanagement contraproduktief, ondat in een vrijwilligersleger de centrale vraag is: "Hoe zorg ik ervoor dat militairen zolang mogelijk in dienst vạn de krijgsmacht blijven". Cruciaal bij de beantwoording van deze vraag is de inriching van het beloningssysteem. Afschaffing van de dienstplicht vraagt om een beloningssysteem dat voldoet aan de wetten van de markt en dat in overeenstemming is met de zwaarte van de functie, de aard van de functie, het opgebouwde human capital, schaarstefactoren en groeimogelijkheden. Dit betekent dat het beloningssysteem in een vrijwilligersleger losgekoppeld moet wor- 
den van het rangenstelsel. Het rangenstelsel is slechts een coördinatiemechanisme, terwi1 het beloningssysteem het schaarstemechanisme is.

De krijgsmacht zal zich moeten aanpassen aan de normen en waarden van de burgermaatschappij willen we op een efficiënte wijze omgaan met de schaarse middelen in de maatschappij. Dit betekent dat zij af dient te stappen van de gedachte dat de krijgsmacht een instituut is met eigen normen en waarden. Het vasthouden aan eigen normen en waarden zal betekenen dat de krijgsmacht altijd een second-best beleid zal moeten voeren. Dit second-best beleid kan zij zich nog wel veroorlover in een dienstplichtigenleger, omdat daar de vulling van het personeel gegarandeerd is. In een vrijwilligersleger dient niet het instituut krijgsmacht voorop te staan, maar het beroep militair. Een beroep net als jeder ander beroep in de maatschappij.

Indien we een dienstplichtigenleger willen inrulen voor een vrijwilligersleger dienen we ook een oplossing te vinden voor de vulling van de mobilisabele eenheden (hoofdstuk 8). Dit is vooral een probleem van de lange termijn, daar op korte termijn dienstplichtigen nog steeds de mobilisabele eenheden kunnen vullen. Het aantal benodigde reservisten hangt ondermeer af van de doelstellingen van de krijgsmacht ten aanzien van de hoeveelheid mobilisabele eenheden, de hoeveelheid materiaal dat beschilkbaar is en de gaten die in de krijgsmacht ontstaan door het sneuvelen van soldaten.

Vooral ten aanzien van de laatste factor is er een duidelijk onderscheid tussen een vrijwilligersleger en een dienstplichtigenleger. De factor schaarste die een vrijwilligersleger met zich meebrengt heeft tot gevolg dat een militaire actie minder snel zal worden ondernomen met een vrijwilligersleger dan met een dienstplichtigenleger, omdat een actie met een vrijwilligersleger tot gevolg kan hebben dat het vrijwilligersleger zonder personeel komt te zitten (hoofdstuk 6). Met andere woorden, in een vrijwilligersleger zal veel zuiniger met het personeel worden omgesprongen, omdat in tegenstelling tot een dienstplichtigenleger in een vrijwilligersleger het personeel schaars is. Hoeveel reservisten nu exact nodig zijn, blijft echter een schatting. Een schatting die gemaakt zal moeten worden aan de hand van de hoeveelheid mobilisabelle eenheden, de hoeveelheid materieel, de risico"s die verbonden zijn aan eventuele acties en een schatting van de hoeveelheid acties.

Indien de welvaartsconsequenties voor de verschillende groepen in de samenleving in beschouwing nemen, blijkt dat de aantrekkelijkheid van een vrijwilligersleger groot is. De overgang van een dienstplichtigenleger naar een vrijwilligersleger levert voor alle betrokken groepen op lange termijn een welvaartsverbetering op, omdat bovendien de leereffecten van de dienstplicht zowel op micro-als op macro-economische niveau te verwaarlozen zijn (hoofdstuk 9). Indien we momenteel reeds zo'n krijgsmacht zouden hebben, zou het heel wat waard zijn om deze te behouden. Doch de keuze voor een vrijwilligersleger is niet vanzelfsprekend, maar ook hier een afweging van de "opportunity costs" tussen een dienstplichtigenleger en een vrijwilligersleger. In termen van "opportunity costs" laat de keuze tussen een dienstplichtigenleger en een vrijwilligersleger zich vertalen naar de vraag wanneer de "opportunity costs" voor de maatschappij in termen van oorlogsschade aan mensen en kapitaalgoederenvoorraad groter is dan de "opportunity costs" voor de soldaten (hoofdstuk 8). De "opportunity costs" voor de soldaten zullen bij een dienstplichtigenlieger altijd groter zijn dan bij een vrijwilligersleger (hoofdstuk 4 en 5), maar de schade aan de mensen en de kapitaalgoederenvoorraad zal bij een vrijwilligersleger groter zijin dan bij een dienstplichtigenleger. Het overgangspunt zal daar liggen waar de schade aan de mensen en de kapitaalgoederenvoorraad duidelijk zichtbaar wordt en niet meer kan worden tegengegaan door het aantrekken van vrijwilligers met welke 
prikkels dan ook. Dit overgangspunt zal zeer dicht tegen het moment van een invasie liggen, omdat de gevechtskracht om een invasie tegen te houden in grote mate afhankelijk is van het beschikbare materiaal. Indien het gevechtsmateriaal op is, begint ook de dienstplichtige militair heel weinig.

Alhoewel een vrijwilligersleger momenteel te prefereren is boven een dienstplichtigenleger zal het niettemin een aanzienlijke klus zijn, om een dienstplichtigenleger in te ruilen voor een vrijwilligersleger. Vele groepen in de samenleving hebben op korte termijn belang bij het voortbestaan van de dienstplicht. Dit hoeven niet alleen de leidende ambtenaren van het Ministerie van Defensie te zijn in hun streven naar budgetmaximalisatie (hoofdstuk 2), ook het publieke besluitvormingsproces kan er toe leiden dat de omschakeling naar een vrijwilligersleger tegen wordt gehouden (hoofdstuk 3). Velen hebben voordeel bij het voortbestaan van de dienstplicht, omdat dat hen een belastingvoordeel oplevert. De meerderheid legt in dit geval een minderheid een last op middels een volkomen legaal publiek besluituormingsproces.

Niettemin hoeft het overgangsproces naar een vrijwilligersleger geen vertraging op te lopen, indien met een aantal zaken rekening worden gehouden (hoofdstuk 8). In ambtelijke organisaties speelt de informele structuur een belangrijke rol. Individuen in een bureaucratie "ruilen" met elkaar in een netwerk, dat vergelijkbaar is met een markt, op basis van "property rights"', al zijn er in het algemeen geen wettelijke instituties om deze rechten te waarborgen. Het is niet alleen budgetmaximaliserend gedrag dat het gedrag van ambtenaren kenmerkt. Elementen als formele en informele structuur, vertrouwen, selectief gedrag en mededinging geven vaak een betere verklaring voor het feitelijke bureaucratische gedrag. Voor de overgang naar een vrijwilligersleger is het belangrijk dat op deze elementen in het overgangsproces ingespeeld wordt, door prestatie en contraprestatie tussen de verschillende delen binnen de krijgsmacht tegen elkaar af te wegen. Niettemin zal de cultuur van de krijgsmacht op korte termijn moeilijk om te vormen zijn, en zal een zekere mate van spanning tussen de cultuur van de krijgsmacht en een perfect functionerend vrijwilligersleger altijd aanwezig zijn.

Ten behoeve van de publieke besluitvorming en de overgang naar een vrijwilligersleger spelen veel meer elementen een rol, dan in een mediaan kiezersmodel kan worden weergegeven (hoofdstuk 2). Toch speelt het kostenaspect in de vorm van belastingprijzen in het publieke besluitvormingsproces de belangrijkste rol. Als aangetoond kan worden dat een dienstplichtigenleger omgezet kan worden in een vrijwilligersleger, terwijl dat tevens geld oplevert, dan heeft dat een belangrijke invloed op de uitkomsten van het publieke besluitvormingsproces. Militaire dienstplicht is immers een vorm van economische politiek met als voornaamste doelstellingen de kosten van arbeid laag te houden en de vulling van de krijgsmacht met personeel te verzekeren.

Aan de militaire dienstplicht zijn ook altijd een aantal nevendoeleinden verbonden. Van deze nevendoeleinden is de wisselwerking tussen maatschappij en krijgsmacht door de dienstplicht de belangrijkste geweest. In een vrijwilligersleger valt deze vorm van binding van de krijgsmacht met de maatschappij weg en zal ook hier op zoek moeten worden gegaan naar een alternatief (hoofdstuk 7).

Bij de wisselwerking tussen maatschappij en krijgsmacht staat de positie van de officieren centraal. De mogelijkheid van een staat in de staat door de krijgsmacht is afhankelijk van hun gedrag. Voor een juiste inbedding van de krijgsmacht in de maatschappij is het belangrijk dat zij er voor zorgen dat de krijgsmacht in algemene en in specifieke zin aanvaard wordt.

Wisselwerking tussen maatschappij en krijgsmacht is een vraagstuk van het op een juiste wijze inbouwen van prikkels in de krijgsmacht, zodat de dynamiek tussen 
maatschappij en krijgsmacht inderdaad verbetert. Deze prikkels kunnen ondermeer worden gevonden door ondergeschikten de mogelijkheid te geven onafhankelijk van hun meerderen te kunnen opereren. Aan ondergeschikten moeten de mogelijkheden openstaan hun meerderen te kunnen weerstaan, zonder dat dit repercussies voor de ondergeschikten oplevert. Dit kan ondermeer vorm worden gegeven door de bevordering van militairen op basis van objectieve maatstaven en de mogelijkheid ontslag te nemen op elk gewenst moment Op deze wijze wordt schaarste geintroduceerd binnen de krijgsmacht en daarmee concurrentie met de burgermaatschappij, waarbij de krijgsmacht slechts kan overleven indien zij zich conformeert aan de normen en warden van de veel grotere burgermaatschappij.

Privatisering van de krijgsmacht is een andere mogelijkheid om de dynamiek van de krijgsmacht te verbeteren. Het primaire doel van privatisering van de krijgsmacht is de krijgsmacht te confronteren met de kosten van haar eigen handelingen, waardoor zij tevens inzicht krijgt in de kosten van handelingen die de maatschappij niet gedienstig zijn. Privatisering introduceert het marktmechanisme in de krijgsmacht, waardoor de dynamiek een geweldige impuls krijgt. Deze impuls werkt in velerlei opzichten positief voor de wisselwerking tussen maatschappij en krijgsmacht, omdat de krijgsmacht door de privatisering op velerlei wijzen direct afhankelijk wordt van de burgermaatschappij. Vooral de onderdelen van de krijgsmacht die taken overnemen in de vorn van externe verzelfstandiging, uitbesteding of zelfs geheel privaat, dragen hier het meest aan bij. Van de oude krijgsmacht hoeft slechts een klein deel over te blijven. De rest is geprivatiseerd.

Na een lange veldtocht langs welvaartseconomie, collectieve goederen, bureaucratisch gedrag, public choice, belastingen-in-natura, kostprijzen, excess-burden, arbeidsmarkten en arbeidsmarktinstrumenten, privatisering en "opportunity costs" eindigt dit proefschrift bij de socialle dienstplicht (hoofdstuk 9).

Socialle dienstplicht heeft dezelfde economische karakteristieken als de militaire dienstplicht, doch kan zich op eén punt niet meten met de millitaire dienstplicht. Sociale dienstplicht kan nooit waar maken dat de "opporturity costs" van de arbeid die onder de plicht valt boven haar marktwaarde kan stijgen. Militaire dienstplicht (hoofdstuk 8) en ook schoolplicht kunnen dit wel. Sociale dienstplicht is dan ook niets anders dan via een dure, bureaucratische en kortzichtige omweg de produktie van die voorzieningen realiseren, die anders niet tot stand zijn gekomen. Socialle dienstplicht laat zich dan ook goed vergelijken met een computerprogramma besmet met het PacMan-virus. In eerste instantie zorgt het computerprogramma voor een voortreffelijk bestand aan gegevens, maar met de vervolmaking van het bestand wordt het PacMan-virus in werking gesteld. Het Pac-Man-virus eet langzaam de bits en bites van het programma op, waardoor het bestand na verloop van tijd wordt vernietigd, en de bezitter van het bestand helemaal opnieuw kan beginnen met een ander computerprogramma. Sociale dienstplicht lijkt op korte termijn aardig, maar tast langzaam maar zeker de fundamenten van het marktmechanisme aan, waardoor de produktie van de sector waar de social dienstplichtigen werkzaam zijn na verloop van tijd als een kaartenhuis in elkaar zakt. 


\section{Summary in English}

In this thesis, entitled "Military Conscription: an economic analysis of the labour component in the armed forces", military conscription is regarded as an economic policy to keep the cost of labour down in the armed forces. The economic cost of conscription becomes clear when we analyse the opportunity costs of conscription. If conscripts were free to choose whether to join the armed forces, many would not have joined under the present day conditions, since for them the costs of conscription exceed the benefits in an extreme way.

In questions concerning warfare in economics the opportunity costs principle is always central. In this thesis the analysis begins with an investigation of these opportunity costs and then uses the results to analyse the building of an allvolunteer force, which will in fact be achieved, if everything goes well, by 1998.

Chapter one concentrates on the structure of the thesis. One of the cornerstones is welfare economics. Welfare economics uses a mechanic view on the state. Translated to military conscription this means that the welfare of the conscript is a central point in the analysis of the economic aspects of military conscription. Also important is the fact that the concept of welfare concentrates on scarcity. Due to conscription the aspects of scarcity of labour in the armed forces are very weak, if not absent.

Conscripts are used in the armed forces to produce the public good defense. The use of these means of production in the armed forces to produce defense leads to a withdrawal of the same means from the civil society, because these means are scarce with regard to the needs in that society. Therefore economic laws are also valid in the armed forces (chapter 2).

In the armed forces two specific functions can be considered: combat functions and non-combat functions. The latter supports the former without the use of violence. The use of violence is essential for combat functions. To fill the combat functions society has a choice between a conscription force and an all-volunteer force. In an all-volunteer force soldiers are recruited on a voluntary basis and salaries are paid from the yield of taxation. In a conscription army the obligation is prominent. Conscripts receive a salary that is lower than the income they could have earned in civil society, if they were not forced to join the armed forces. In other words conscripts pay a tax-in-kind (chapter 4). The burden of conscription or conscription tax is characterized by the difference between the salary and the opportunity costs of a conscript. The opportunity costs are equal to the addition of the alternative civil salary of the conscript and the "sick-to-death-premium" caused by the loss of non-pecuniary advantages in civil society.

The conscription tax is about 10.000 guilders a year for every conscript not including the cost of conscription that will appear after military service because of the loss of working experience.

Without considering the collection costs of the conscription tax, the tax also causes a relative change of factor costs in the armed forces. Conscription makes labour cheap and this will mean that the armed forces are producing the public good defense with a greater amount of labour than is necessary. Conscription conceals the real costs of the armed forces and causes an "excess-burden" to the amount of 2.1 billion guilders a year, because due to conscription the substitution 
of labour for capital, military labour for civilians and inexperienced labour for experienced labour does not occur. In addition, the misallocation caused by conscription leads to excessive forms of boredom and neglect of the primary living conditions of soldiers. However, conscripts are not allowed to resign if the situation in the armed forces is not satisfactory.

The excesses of conscription are not only visible nowadays. In the 19th-century conscription had a massive influence on ordinary life (chapter 3). In an economic sense, the essential element of 19th-century conscription was the replacement system. Due to this system it became almost impossible to change the Napoleonic conscription system into an all-volunteer force.

In order to achieve an all-volunteer force, it is important that the armed forces are able to compete with civil society in terms of working conditions and working circumstances. In this comparison all the aspects of the conscription-tax will be illuminated once again (chapter 6).

In an all-volunteer force the soldier and the armed forces are confronted with two kinds of contracts. Apart from the written contract there is an unwritten contract, wherein the armed forces are obliged to respect the soldier as a human being, to give the soldier useful work and the opportunity for individual development. The soldier is obliged to fulfil his task as well as possible in a disciplined manner.

The tasks of the military in the armed-forces wil be different in the future than they were prior to the fall of the Berlin Wall in 1989. Apart from NATO-tasks, the use of military personnel for UN-missions will be one of the most important tasks for the Dutch armed-forces. For the military this means that their task will not be purely producing combat power. The future soldier must be able to negociate, intercede and reconcile, while civilian education will be necessary for humanitarian aid-operations. The civilian education programme should be provided by the armed forces, and will give military occupation a new and attractive perspective without raising salaries.

In an all-volunteer force the recruiting and selection process is an essential element of the system. Contrary to a conscription army, labour is scarce in an allvolunteer force. Potential volunteers must be treated with the greatest concern. If the supply of eligible volunteers is not enough to fill the needs of the armed forces, then research will be needed to see if this is not caused by selection demands that are too strict. High selection standards do not just mean a lot of wasted money in terms of extra salaries and recruitment costs, but high selection standards also cause high social costs, since eligible people can not obtain a proper job.

In an all-volunteer force supply of labour must be as great as possible. This means that the role of women in the armed forces should also be stressed. Without proper integration of women in the armed forces an all-volunteer force will never be efficient, because a sufficient supply of women will enlarge total supply, which will keep salaries down.

Maybe more important than attracting new volunteers is to limit the demand for new volunteers. In chapter 5 it is stressed that the demand for military personnel is so large, because the costs of using these people are so low. The high demand is caused by conscription. If the real costs of personnel must be paid, demand will be expected to go down. Demand diminishes because the armed forces are confronted with the real costs. The demand for military personnel can also be lowered by a few different means. The armed forces have always stressed the concept of a 'young and vigorous force'. A young force also means an 
inexperienced force, while the physical element will be less importantin in the future armed forces. The 'up-or-out' personnel management system also cautes 'young-force', because experienced people will leave the armed forces when the armed forces can not provide any further challenge or promotion. This meanis that in an all-volunteer force the pay system should be separated from the ranting system. Rank is just a coordination mechanism, while the pay system is a scatcity mechanism.

If we want to change the conscription force into an all-volunteer force, we should also find a solution for the reserves. This is a long-term problem because on a short-term basis, it will still be possible to fill the reserves with conscripts (chapter 8). The amount of reserves needed depends on the objectives of the armed forces concerning the amount of extra units for mobilization, the amoun of capital available and the losses of personnel in combat-action.

Especially concerning the last issue there is an important difference between an all-volunteer force and a conscription force. Scarcity brought about by an allvollunteer force means that care will be taken considering actions, because an action with an all-volunteer force can mean that the volunteer force is out of personnel. In other words the use of personnel will be more efficient in an allvolunteer force, because in contradiction to a conscription force personnel in the all-volunteer force is scarce (chapter 6).

The attractiveness of an all-volunteer force is great. But the choice for an allvolunteer force is not that simple. It is a balance between the opportuntity costs of a conscription army and an all-volunteer force. Translated in opportunity costs, the choice between the two is a question of when the opportunity costs for society in terms of war damage to people and capital and the opportunity costs of soldiers is larger (chapter 8). The choice for a conscription army can be sincere in case of an invasion, but it is important to notice that the point of transition between an allvolunteer force and a conscription army will be very close to the point of invasion, because combat power to keep an invasion out of the country depends heavily on available material. Without that material a conscript cannot function either.

Although an all-volunteer force is preferable to a conscription force nowadays, it will be difficult to realize the transition from a conscription force to an all volunteer force. Many groups in society benefit from the continuance of conscription. This is not just true for the leading military in the Ministry of Defense in their pursuit for budget maximalization (chapter 2), but also public choice can lead to a situation whereby the transition to an all-volunteer force will be opposed. A lot of people benefit from the continuance of conscription, because it is a tax-benefit for them (chapter 3).

Nevertheless, the transition from a conscription force to an all-volunteer force can occur without any delay if some things are addressed. Elements like formal and informal structure, confidence, selective behaviour and competition often give a better explanation for practical behaviour of bureaucrats than budget maximalization. If these elements are used in the transition period in a quid-proquo surrounding, the transition to an all-volunteer-force can be accomplished in a successful way. However, the culture of the armed forces will not be transformed so easily and that means that some tension will always be present (chapter 8).

Concerning the public choice side of the transformation; it is of eminent importance that all costs are considered. If it can be proved that the transition to an all-volunteer force saves money, the result will be totally different. 
Military conscription also served few secondary objectives. The most important one is the interaction between society and armed forces by conscription. In an allvolunteer force this kind of interaction disappears and also in this respect an alternative must be found (chapter 7).

Interaction between society and the armed forces is a question of incentives. How can incentives be used in the armed forces to improve the dynamics between society and the armed forces. Apart from the extra opportunities given to subordinates with regard to their superiors in the armed forces, privatization of the armed forces is an important opportunity to improve the dynamics of the armed forces. The primary objectives of privatization are to confront the armed forces with the costs of their own actions, through which they also see the costs of actions that are not beneficial to society.

After a long campaign along welfare economics, public goods, bureaucratic behavior, taxes-in-kind, cost prices, excess-burden, labour markets and labour market-instruments, privatization and opportunity costs, this thesis ends with civil service. Compulsary civil service has the same characteristics as military conscription, but can never compete with military conscription on one point. The opportunity costs of labour under civil service can never exceed its market value. In case of military conscription this is possible during an invasion. Compulsary civil service is nothing else than realizing the production of these public goods via a bureaucratic and short-sighted way, that would never have been produced in a normal democratic public choice situation. 
Literatuuropgave.

Abrams, M., "Some effects of British millitary service", in Sol Tax (ed), The draft. Chicago 1967

Abva-Kabo, "Niemand staat graag macht af" "Aaneen, Zoetermeer, 29 augustus 1992.

Algemene Vereniging Nederlandse Militairen, Veroeling in dienst, Utrecht, 1989.

Allers, M.A., Kosten van overdrachten voor particulieren en huishowdens, Researchmemorandum nr. 483, Instituut voor economisch onderzoek, Faculteit der Economische Wetenschappen, Rijksuniversiteit Groningen, Groningen, 1992.

Altman, S. H en Fechter A. E. "The supply of military personnel in the absence of the draft," American Economic Review, mei 1967.

Angrist, J. D., "Lifetime earnings and the Vietnam era draft lottery. Evidence from so" cial security administrative records," American Economic Review, juni 1990.

Baakman, N.A.A. (ed.), Overheid en onderneming, een inleiding, Heerlen, 1991.

Barraclough, G., The modern origins of modern Germamy, Oxford, 1976.

Becker, G. S. "Investment in human capital: a theoretical analysis," Journal of Political Economy, Vol. 70, 1962.

Bergeijk, P.G.A. van, Economie van de oorlog ${ }_{r}$ Rotterdam, 1986.

Berger, M.C. en T. Hirsch, "The civilian earnings experience of Vietnam era veterans", Journal of human resources, herfst 1983.

Biesmeijer, E. en W.C. Verbaan, "Zelfbeheer I: de ambtenaar wordt manager", Openbare Uitgavert,16, nr. 5, september 1984

Binkin, M., The military pay muddle, The Brookings Institution, Washington, D.C., 1972.

Binkin, M., U.S. Reserve forces: the problem of the weekend warrior, The Brookings Institution, Washington, D.C., 1975.

Binkin, M. en S. J. Bach, Women and the military, The Brookings Institution, Washington, D.C., 1977.

Binkin, M., H. Kanter en. H.Clark, Shaping the defense civilian work force, The Brookings Institution, Washington, D.C., 1978.

Binkin, M. en I. Kyriakopoulos, Youth or experience? Manning the modern military. The Brookings Institution, Washington D.C., 1980.

Binkin, M. en I. Kyriakopoulos, Paying the madem military, The Brookings Institution, Washington, D.C., 1981. 
Bliven, B., Jr. , Volunteers one and all, New York, 1976.

Bogaert, K.A.M., "Aspecten van het economisch handelen in de militaire organisatie," Maandschrift Economie, nr 29, 1965.

Boneschansker, E. en $\mathrm{H}$. de Groot, "Verzelfstandiging van overheidsdiensten: wanneer en hoe?", Openbare Uitgaven 24, nr.3, mei 1992;

Boorsma, P.B., "Privatisering", Openbare Uitgaven, 14 nr.6, oktober 1984

Boorsma, P.B. en W.T.M. Bokkes, "De economische baten van hulpagenten", Openbare Uitgaven 23, nr.5, september 1991.

Breton, A., en R. Wintrobe, The logic of bureaucratic conduct, Cambride, 1982

Buchanan J.M., Cost and choice, Chicago, 1969.

Campagne, G.T., "Over het ontstaan en de ontwikkeling van het instituut van de dienstplicht," Kernoraag, nr. 4, 1968.

Canby, S. L., Military manpower procurement, a policy analysis, Lexington, 1972.

Centraal Bureau voor de Statistiek, Sociaal economisch panelonderzoek 1989 Vragenlijst A1, Heerlen, 1989.

Centraal Bureau voor de Statistiek, Statistisch Zakboek, Voorburg/Heerlen, diverse jaren.

Chu, D.S.C. en E. Norrblom, Physical standards in all-volunteer force, The Rand Corporation, Santa Monica, 1974.

Coase, R.H., "The nature of the firm", Economica 4, 1937.

Coase, R.H., "Accounting and the theory of the firm", Journal of accounting and economics 12, 1990

Coase, R.H., "The institutional structure of production", The American Economic Review, september 1992

Cooper, R.V.Lu, Military manpower and the all-volunteer force, Rand Corporation, Santa Monica, 1977.

Crane J.R. en D.A. Wise, "Military service and the civilian earnings of youth" in D.A. Wise (ed.), Public sector payrolls, Chicago, 1987.

DeTray, D. N., "Veteran status as a screening device," American Economic Review, maart 1982. 
Dijkhuizen, N. van en P.HJ. Suijker, Is rang alleen rang als er rang op staat? Den Haag. 1991.

Downs, A., Inside Bureaucracy, Boston, 1967.

Duindam S., "Beroepsleger of dienstplicht?", Economisch Statistische Berichten, 7-101992.

Duindam S., "De kosten van dienstplicht", Economisch Statistische Berichten, 29-4-1992.

Duindam, S., J. Leestemaker en R. Zaal, "Rapport pan het bezoek aan SCVR, Zweden door een delegatie oan VVDM, Nederland, 15 t/m 19 augustus $1991^{\mathrm{t}}$, Commissie Internationale Zaken VVDM, Utrecht, 1991.

Engelberts, I.M., Moet de plaatswerwanging worden afgeschaf, Nijmegen, 1848.

Felix, P., "Verzelfstandiging als privatiseringsvariant", Economisch Statistische Berichten, 5 maart 1986.

Fisher, A. C., "The cost of the draft and the cost of ending the draft," American Economic Review, juni 1969 .

Gay, R. M., Estimating the cost of on the job training in military occupations: a methodology and pilot-study, Rand Corporation, Santa Monica, 1974.

Gifford, B. R. en L. C. Wing (eds.), Test policy in defense, Boston, 1992

Goldscheid, R. Staatssazialismus oder Staatskapitalismus: ein finanzsoziologischer Beitrag zur Lösung des Staatsschulden-Problems, Wien, 1917.

Hansen W. L.en B. A. Weisbrod, "Economics of the military draft," The Quarterly Journal of Economics, Vol.81, 1967.

Haselbekke, A.G.J., Profijtbeginsel en politieke beshuituorming, Leiden, 1989.

Henderson, J.M. en $\mathrm{R}$. E. Quandt, Microeconomic theory: a mathenatical approach, New York, 1980.

Hitch, C. I. en R. N. McKean, The economics of defense in the nuclear age, Cambridge, 1960.

Janowitz, M., "The logic of national service", in Sol Tax(ed), The draft, Chicago 1967

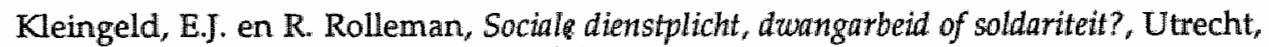
1990.

Knight, F.H., Risk, uncertainty and profit, Cambridge, 1946.

Koutsoyiannis, A., Modern Microeconomics, London 1975. 
Kraan, DJ, "Bureaucratietheorie en de organisatie van de rijksdienst", Openbure uitgaven, $24 \mathrm{Nr} .4,1992$.

Kruseman, A, Ooer de nationale militie en remplacement, Amsterdam,1853.

Lingle, C. "On the real costs of military conscription," South African Joumal of Economics, Vol. $57,1989$.

Maatschappelijke Raad voor de Krijgsmacht, De vrouw in de krijgsmacht, advies nr. 7, Den Haag 1984 .

Maatschappelijke Raad voor de Krijgsmacht, Evaluatie maatschappelijke aanvaarding van de krijgsmacht 1988-1991, adwies 14/1, Den Haag, 1991.

Maatschappelijke Raad voor de Krijgsmacht, Verhouding burger-en militair personeel. advies rur. 16, Den Haag, 1989.

Maatschappelijke Raad voor de Krijgsmacht, Contractduur, advies nr. 24, Den Haag 1992.

Maatschappelijke Raad voor de Krijgsmacht, Intemationalisering van de krijgsmacht, advies nr. 25, Den Haag 1992.

Maatschappelijke Raad voor de krijgsmacht, Standpunt over het advies wan de commissiedienstplicht (commissie-Meijer), advies nr.26, Den Haag, 1992.

McNeill, W.H., "The draft in the light of history", in Sol Tax(ed), The draft, Chicago, 1967.

Meijer-commissie, Naar een dienstplicht nieuwe stijl, Den Haag, 1992, (bevat tevens achter"grondbundel).

Mierlo J.G.A. van, "Ambtelijk gedrag in bureaucratische organisaties," in A.F.A Korsten en, Th. A.J. Toonen, Bestuurskunde, Leiden, 1988.

Miller J. (ed, Why the draft, the case for the wolwnteer force, Baltimore, 1968.

Ministerie van Defensie, Brief 90/377/23459 wan de toorzitter van de Tweede Kamer der Staten Generaal, 's»Gravenhage, 14 november 1991.

Ministerie van Defensie, Defensienota 1991, Den Haag, 1991.

Ministerie van Defensie, Jaaroverzicht dienstplichtgegevent, Den Haag, diverse jaren.

Ministerie van Defensie, Prioriteitennota, 's-Gravenhage, 1993.

Mol, N.P., Bedrifseconomie voor de collectieve sector, Alphen aan de Rijn 1989.

Mol, N.P., "Zelfbeheer II: kostenplaatsenbudgettering", Openbare Uitgaven 16, nr. 5. september 1984. 
Mol, N.P. en H.A.A. Verbon, Institutionele economie en openbant bestuur, perspectieven op de verzelfstandiging wan overheidsdiensten, s-Gravenhage, 1993

Mommersteeg-commissie, Verplicht of vrijwilitg dienen, Den Haag 1976.

Moskos, C.C., jr., L"armee de metier Americaine (1973-1990): constat de carence, Fondation pour les études de defense nationale, Parijs, 1991.

Moskos, C.C., jr., The american enlisted man, New York, 1970.

Moskos, C.C., jr. "Form institution to occupation: trends in the military organization", Armed forces and society, vol. 4,1977 .

Niskanen, W., Bureaucracy and representative governtnent, Chicago, 1971.

NordBerFN, Nordic standlyy forces in United Nations seroice, Stockholm, 1976.

Oi, W. "The economic cost of the draft," American Economic Review, mei 1967.

Phelps, E. S. (et al), Microeconomic foundations of employment and inflation theory, New York, 1970.

Pigou, A.C., The economics of welfare, London, 1962.

Putten, J. van, "Geen reden te sterven voor de staat", NRC-Handelsblad Opiniepagina, 31-10-1992.

Robbins, L., An essay on the rature and significance of economic science, London, 1962.

Roos , N.H.M. "Opiniepagina" NRC-Handelsblad 3 november 1992.

Rosen, Harvey S, Public finance, Homewood, 1988.

Rosen, $\mathrm{S}$ : en $\mathbb{P}$. Taubman, "Changes in lifecycle eamings: what do social security data show?," Joumal of human sciences, zomer 1982.

Roux, A., "The economics of alternative national service," South African Journal of Economics, Vol. 59, 1991.

Samuelson, P.A., "The pure theory of public expenditure", Review of Economics and Statistics 36,1954 .

Schroeff, H.J. van der, Kosten en kostprijs, Amsterdam, 1979.

Siccama, J.G., "Militaire dienstplicht ondoelmatig en onrechtvaardig", in C. Homan en J.G. Siccama (eds.), Dienstplicht, afschaffen of uitbreiden? Den Haag, 1990.

Smidt, E. (et al), "Een verloren jaar; de relevantie van militaire dienstplicht voor de arbeidsmarkt", Maatschappij en krijgsmacht nr. 14, Den Haag, augustus 1992. 
Smith, A., The weallh of nations, New York, editie 1937.

Spil, C.B.A., "Een economische waardering van de dienstplicht," Economisch Statistische Berichten, 10-8-1966.

Spits, F.C., "Klassedienstplicht in de negentiende eeuw, plaatsvervanging en afkoop", Driekwart eeuw historisch leven in Den Haag, 1975.

Stevens, L.G.M., Elementair belastingrecht, Deventer 1985.

Stichting Maatschappij en Krijgsmacht, De prijs van defensie, Den Haag, 1983.

Stigler, George J., "Information in the labor market," The journal of political economy. Vol, 70, 1962.

Swartz, S., "The relative earnings experience of Vietnam and Korean era veterans," Industrial and labor relations review, juli 1986.

Theeuwes, J., "Een stilliggend doperwtje", Trouw , 20-12-1991.

Tiesinga, Marie-Louise, "Dienstplicht, van militaire naar sociale?," concept tekst voor Armex Defensie magazine, 1992.

Tollison, Robert D., "The political economy of the political draft," in James M. Buchanan en Robert D. Tollison (eds.), Theory of public choice, Ann Arbor, 1972.

Tweede Kamer der Staten Generaal, Rijksbegroting Hoofdstuk X, Den Haag, diverse jaren.

Tweede Kamer der Staten Generaal, Vergaderjaar 1990-1991, 21.800 X, nr. 39, Antwoorden op vragen van de vaste commissie voor Defensie, Den Haag, 1991.

Velthoven, B.C.J. en F.A.A.M. van Winden, "Privatisering, een politiek-economische benadering", Openbare Uitgaven 16, nr.6, oktober 1984.

Vereniging van Dienstplichtige Militairen, Einde oefening, Utrecht, 1992.

Vereniging van Dienstplichtige Militairen en Stichting Maatschappij en Krijgsmacht, Dienstplicht: zin, tegenzin en toekomst, Den Haag, 1991.

Vereniging van Dienstplichtige Militairen, Maandblad "twintig", Utrecht, april 1993

Veterans administration reports and statistic service, Research monograph 15: education and income characteristics of veterans maart 1979, Washington, 1981.

Volkskrant, de.,"In lopen hebben de soldaten van luchtmobiele brigade geen zin," 20-11-1992, blz. 3 . 
Volten, H., "Dienstplicht, legervorming en de Nederlandse Economie," Economisch Statistische Berichten, 25-01-1967.

Wagner, R. E. "Conscription voluntary service and democratic fiscal choice in J. M. Buchanan en R. D. Tollison (eds.), Theory of public choice, Ann Arbor, 1972.

Wolfson, D.J., Publieke sector en econontische orde, Groningen, 1988. 


\section{Namenregister}

Abrams, $\mathrm{M}$.

Algemene Rekenkamer

Arnsterdam

Angrist, I.D.

Bach, S.).

Barraclough, $G$.

Baskir

Berger, $M_{i} C$.

Binkin, $M$.

Bliven, $\mathrm{B}$. j $\mathrm{j}$.

Bokkes, W.T.M.

Boorsma, P.B.

Brazille

Breton, A.

Buchanan, J.M.

Campagne, C.T.

Canby, S.L.

Centraal Bureau voor de

Statistiek

Cesear, J.

\section{Chili}

Christen-Democratisch

Jongeren Appel

Chu, D.S.C.

Cooper, R.V.L.

Cort van der Linden

Crane, J.R.

Cromwell

Cyprus

Defense Manpower

Commission

DeTray, D.N.

Downs, A.

Duitsland

Edgeworth, $\mathrm{F} Y$.

Eland, K.

Evians

Federatie Nederiandse

Vakvereniging

Finland

Frankrijk

Frederick de Grote

Frederick Wilheln I

Gaulle

Gay, R.M.

Gemeentepolitile

Den Haag

Goldscheid, R.

Goltstein, van

Griekenland

Groot-Brittannie

Hansen, R.N.

Hardenberg
178

132,143

60

57

111

179,181

102

57

112

90

25

$25,129,135$

131

1.67

15

40,42

$87,131-133$

57,63

16

131

173-174

100,106

$54,65,75$

52

56

16

96

116

56

29

$104,179-180$

9

45

102

46

96

39,49

179-180

180

131

76.115

111

5

43,45

131

$112,117,172,178$

55

180
Haselbekke, A,G.J.

$167169-170$

Hirsch, $T$.

57

Hitch, C.J.

21-23

Hoekzema, staatssecr. $\quad 106$

Janowitz, M. $\quad 178$

Johnsan, presildent $\quad 100$

Knight, F.H. $\quad 15$

Koning Willem I 189

Koninklijke Militaire

Academie $\quad 59$

Korea 111

Kraan, D.J. $\quad 137,140$

Landmacht, Koninklijke $\quad 23,26-28,71,77,85-86$,

$91,96,108,130$,

$147,149,169$

Langen, de $\quad 58-59$

Leibenstein 79

Legerkorps, 1e $\quad 28,71,76,117$

Libanon 96

Lubbers, regering $\quad 50$

Luchtmacht ${ }_{s}$ Koninklijke $23,26,71,85-86,91$, $147,149,169$

Maatschappelijke Raad

voor de Krifgsmacht $86,106,111-112$,

134

Machiavelli $\quad 19,44,130$

Marechaussee, Koninklijke 23, 26, 71

Marine, Koninklijke $\quad 23,26,71,85-86$,

$91,110,126,147$,

McKean, R.N.

149,169

21-23

McNamara, R. 101-102

McNeill, W.H. 181

Meijer, commissie $\quad 46,49,60,76-79$,

81,113

Miller, J.C.

153

Ministerie van Defensie $25-27,30,45$,

$103-104,106,129-130$,

$143,147,164,174$

179,193

Ministerie van Sociale

Zaken

174

Ministerie van Welzijn,

Volksgezondheid

en Cultuur 163

Mommersteeg, commissie $\quad 46,76-79$

Moskos, C.C. jr.

73,183

Napoleon

Nederland

$5,40,43,127,181$, 189

$40,54-55,57-58,60-62$. $68-70,73,90,97$,

$105,108,112,115$,

$117,125,130,132-$

$133,153,171,175$

$177,181,188-189$

Nigeria

96

Niskanen, W.

Noord-Atlantische 
Verdrags Organisatie Norrblom, E.

Oostenrijk

Pareto, V.

Pentagon

Peru

Pigou, A.C.

Phelps, ES.

Plato

Pruisen

Raad van State

Research voor Belleid.

Robbins, L

Rosen, S.

Rusland

Scandinavië

Scharnhorst

Scheffer, P.

Schwartz, $S$.

Siccama, J.G.

Sjaastad, L.A.

Smith, A.

Sociaal en Cultureel

Planbureau

Spits, F.C.

Stein

Sticht, T.G.

Strauss

Taubman, $P$.

Ter Beek, $R$.

Theeuwes, $\mathrm{J}$.

Tokio

Tweede Kamer

Verenigde Naties

Verenigde Statten

Vereniging van Dienst-

plichtige Militairen

Veterans Administration

Vietnam

Weber

Wintrobe, $\mathrm{R}$.

Wise, D.A.

Wolfson, D.J.

Zeeland

Zuidema, bureau

Zweden
$86,90-93,97,190$

100,108

180

10-16

102

131

14,36

85,89

8

$7,180-181$

153-154

81

$5,15,187$

56

180

94

181

173

56

60

55

5-7, 16-17, 187

174

39,41

181

102-104

102

56

125

51

94

$43-45,174$

$25,86,90-97,135$,

$152,161,166,190$

$54,56,70,73-74,76$

104-105, 109, 111-112,

$116,169,172,178-179$,

181-182, 189-190

45-46

57

$57,103,111$

171

167

56

23

60

123-124

$25,94,96$ 



\section{Zakenregister}

Aarbod van vrijwilligers

$\triangle B O H Z I S-f o r m u l l e$

Agentschappien

Afkoop van de dienstplicht

Afstoten

Afwenteling

Agemene dienstplicht

Allocatie in de krijgsmacht

Arbeidsaanbodtheorie

Arbeidsinspectie

Arbeidsomstandigheden

Axbeidspool

Arbeidsmarkt

Arbeidsmarktinstrumenten

Arbeidsvoorwaarden

Army Alpha

Army Forces Qualification Test

Army General Classification Test

Armed Services Vocational Aptitude

Battery

ASVAB-misnorming

Asymmetrische informatie

Avontuur

Baalpremie

Baten-lastenstelsel

Beginsel van de bevoorrechte verkrijging

Behoefte aan vrijwilligers

Belasting

Belasting-

-heffing

-in-natura

-innen

-subsidie

-ontduiken

-ontwijken

Belastingprijzen

Berniddeling

Beroepsmilittairen

Beslissen, gebruiken en betalen

Besluitwormingsproces

Bevelhebber

Bewaking

Bezoldigingssystematiek

Bilateral-monopoliemodel

Boter en kanonmen

Brigades

Budget-constrained-region

Budgetmechanisme

Budgetmaximalisatie

Budgettaire kosten en baten

Budgettaire last van militaire arbeidskrachten

Buteaucratische organisaties

Burgers

Burgers in uniform

Burgerzin

Centraal geleide economieèn

Chef van de Defensiestaf

Civiele opleiding

Classificatiesysteem

Classificeren van vrijwilligers

Coalittevorming

Collectief goed defensie

Collectieve besluitvormingsproces

Collectieve lastendruk

Combinatie van kapitaall

en arbeid

Confectiepak

Contractmanagement

Coördinatiemechanisme

Cultuur in de krijgsmacht

Defensienota 1968

130

Defensienota 1974

77

Defensienotta 1984

Defensienota 1991

26,65

130

Defensieoutput

Demand-constrained-region 32

Dell'arte della guerra

17,44

Dienstplicht

107,15

155,180

Dienstplicht-

- als subsidie

8

- en de dood

- en de wisselwerking tussen

maatschappij en krijgsmacht

- en keuzevraagstukkken

- en opbrengsten

- en schaarste

- en sociale kosten

- en verplichting

- en welvaartseconomie

Dlenstplichtbelasting

Dienstplichtigenleger

$28 \quad$ Economische kosten van de militair $\quad 51$

Differentiele beloning

Directeuren-generaal

Doelmatigheidsbeginselen

Duur van een contract $\quad 86$

30,145 ,

167

65,151

\section{1}

29

24,65

135

44
Economic rent

Edgeworth-box

Efficiëntiewinsten

Eilandentheorie

Ergonomisch probleem

Ergonomische investeringen

Ervaringsjaren
51

55,155

10

139,14

85,89

112

$108-112$

57 
8, 78 154,175 .

Exclusiviteit

Externe effecten

21

21

137, 139,

144-145

132

100, 108

100, 108

45

39

22, 149 ,

162

12-14

108, 146

122

126

106, 108

114

115

106, 112

143

70

$24,71,73$,

107,136

$6-7,22,25$,

67, 141,

158

23

73

23,136

163

153

154, 165

29

25

93

$6,81,83$,

88,115 ,

160,177

88,91

60

Humanitaire dienstverlenting

Hypothese-Siccama

Indicator voor het produkt

gevechtskracht

$41,61,175$

110

$22,46,65$,

91,148

160
Interne verzelfstandiging

Invasie

Invisible hand

Joint consumption

21

Jonge en krachtige krijgsmacht

Kader-millitieleger

Kapitaal-arbeidverhouding

69

Kapitaalmarkt

Kazemes

Kerntaken van de krijgsmacht $\quad 149$

Keuring

Keuringsplicht

Koppeling van rang aan salarisschaal

Kosten-baten analyse

Kosten wan klleding en huisvesting

Kosten van militaire en burgerarbeid

Kosten wan pensionering

Kostprijsberekening

Koude Oorllog

Kwalliteit

Landmilitie

Landstorm

Leereffecten door de dienstplicht

Legerkorpstroepen

Levenstisico

Liberalen

Lobbyactiviteiten

Loon-en factorprijsdiscriminatie

Loon-kapitaalkostenratio

Loopbaanverlies

Loterijsysteem

Lowest-supply-price drafted-first(LSPDF)

Maatpak

Maatschappelijke aanvaarding in

algemene zin

Maatschappelijke aanvaarding in specifieke zin

Maatschappelijke inefficiëntie

Maatschappelijke kosten en baten wan de

dienstplicht

Macho-imago

65,15

110

Marginale private kosten

36

Marginale sociale kosten

36

Matching

83,94

Mechanische visie op de staat

9,29

Mededinging

Mediane kiezersmodel

Micro-economische analyse

Militaire deskundigheid

Militaire personeelssysteem

Militaire traditie

Militairen en burgers

Militia

168

34,11

65

24

74,12

74

71,10

7

Militiewet

40,43

Mix van ervaren en onervaren militairen 74,11

Mobilisabele eenheden

77,11

154, 
Mobilisatiecomplexen

Aonopoliesituaties

Mapoleontische conscriptiestelsel

Japoleontische Rijk

Jationale bureaus

Jationale noodtoestand

Neo-klassieke theorie

Netto burgerloon

Viet-gevechtsfuncties

viet-gevechtsonderdelen

Jiet-geweldsfuncties

Non-salariskosten

Joordse-systeem

Jummerverwisseling

mbudsman

Onderbroken loopbaan

Dnderhandeling

Ondersteunende eenheden

ongeschreven contract

intgroening

Ontwijkingsgedrag

Dorlogstijd

borlogswoering

pleiding

pkomstplicht

pportunity costs

psporingsbevoegdheid

Organisatie van de krijgs macht

Overgang van een dienstplichtigenleger

aar een vrijwilligersleger

ac-Man-virus

areto-efficiëntie

articuliere bewakingsdienst

atriotisme

eace-enforcing

leace-keeping

ensionering

ersoneelsbeleid

ersoneelssysteem

laatswervanging

olitie

olitieke besluitvormingskosten

olitieke besluitvormingsproces

'olitieke neutralisatie van het korps

\section{ifficieren}

restatiebeloning

rikkels
40,42

40,127

31

119

37,167

53

73,107

136,159

24

25

72

92,96

40

132

56

86,94

70

90

84

61,183

88

5-6, 118

61,93

153,158

14-15, 41,

$42,52,81$,

99, 142,

155,164 ,

174,184

25

25

75,113 ,

122,154 .

158,167

185

$11-14,16$

69

49

$25,91,92-$

93

$25,91,92-$

93

83

129

83

$39-45$

25

$47 \quad:$

$22,33,46$,

49

132

122

$67,83,107$,

$138,148-$

149,151 ,

162,175
Prijsregulering

Primaire arbeidswoorwaarden

139,143

Principaal-agent model

Prioriteitennota

Privatisering

Privatisering van de krijgsmacht

Profijtbeginsel

Project 100.000

Promotiesysteem

Property rights

Public choice

$30,32-3$

26

$136-140$

152

140,161

59,136

$101-103$

133

1168

37

Raad van Commissarissen

139,149

Reactionair-conserwatieve

groepering in de Tweede Kamer

43-44

Rang

Rangen en beloningen

Rangenstelsel

115,160

120

121

Ranginflatie

$123-124$

Reconstitutievermogen

159

Rechts- of verdelingsbeginselen

Referendum

59

47

Registratieplicht 1.54

Remplaçant 41

Renaissance 39

Reserveringloon

Reservisten

Retention-rate

$52,85,8$

165

120

Risico-aversies $\quad 87,95$

Rivaliteit

Rotatie

21

161

Salarisschaal

161

Schaarste

$14,16,2$

65,78,

165,174

Schade aan mensen en kapitaalgoederenvoorraad

Schoolplicht

Secretaris-generaal

17,181

26

82,88

Secundaire arbelidswoorwaarden

97,145

Selectie

99,103

45,113

Selectieprocedures

81.

Selectieproces

Selectiviteit

167

Sociaal Economisch Panelonderzoek 57,64

Sociale dienstplicht

Sociale kosten

Sociale kosten van de dienstplicht

17,173

14,56

81

Sociale welvaartsfunctie

Staande leger

Staat-in-de-stagt

Staatsgrepen

Statistisch besluitvormingsprobleem

Status van het beroep milftair

Staven van de Koninklijke Landmacht

Stemmenruil

Strategisch besluitvormingsproces

Subsidiariteits beginse]

Subsidie 
Sunk cost

Supervisors

Technologíe

Teeth-to-taul-ratio

Toekomstig inkomen

Untbesteding

Unie van Utrecht

United Nations University

Up-or-out personeelsbeleid

Verdeling van de dienstplichtbelasting

Verdelingsbeginselen van de Langen

Verhouding burger-militair

Verhouding kapitaal-arbeid

Verhouding onervaren-ervaren

werknemers

Vermaatschappelijking van de

kitigsmacht

Verveling

Verzoening

Verzorgingsbeginsel

Verzelfstandiging

Vislie op de staat

VN-departement

VN-instituut

VN-operaties

VN-taken

Volkomen concurrentie

Vorm van privatisering

Vraag naar vrijwilligers

Vredesoperaties

Vuijwilligersaanbod-functie

Vtij willigersleger

Vrijwilligersleger-

- rn sociale kosten

Virouw in de krijgsmacht

Vrouw in de ME

Vrouw-man relatie

Vrouwen op de schepen bij de

Koninklifke Marine

Vrouwenkorpsen

Wachtlopen

War on Poverty

Wealth of Nations

Weberiaanse model

Weddeverhoging

Weekend-strijders

Weigeryuppieg

Welvant

Welvaartseconomie

Werkloosheid

Wet Gewetensbezwaarden

Werving

Wisselwerking tussen maatschappii
75,12

140,1

$\begin{array}{ll}\text { Zelfbeheer } & 137 \\ \text { Zelfstandige bestuursorganen } & 137\end{array}$

Zelfverdediging $\quad 25$

Zwaardkracht 23 